UNIVERSIDADE DE SĀO PAULO

INSTITUTO DE GEOCIEENCIAS

\title{
ESTUDO DA SEDIMENTAÇÃO \\ NEOGÊNICO-QUATERNÁRIA NO MUNICÍPIO DE SÃO PAULO: CARACTERIZAÇĀO DOS DEPÓSITOS E SUAS IMPLICAÇÕES NA GEOLOGIA URBANA.
}

\author{
Harmi Takiya
}

Orientador: Prof. Dr. Paulo Milton Barbosa Landim

TESE DE DOUTORAMENTO

Programa de Pós-Graduação em Geologia Sedimentar

SÃO PAULO

1997 


\title{
ESTUDO DA SEDIMENTAÇÃO NEOGÊNICO- QUATERNÁRIA NO MUNICÍPIO DE SÃO PAULO: CARACTERIZAÇÃO DOS DEPÓSITOS E SUAS IMPLICAÇÕES NA GEOLOGIA URBANA
}

HARMI TAKIYA

Orientador: Prof. Dr. Paulo Milton Barbosa Landim

\author{
TESE DE DOUTORAMENTO
}

\section{COMISSÄO JULGADORA}

Nome

Presidente: Prof. Dr. Paulo Milton Barbosa Landim

Examinadores: Prof. Dr. Claudio Riccomini

Prof. Dr. Aziz Nacib Ab'Saber

Prof. Dr. Bruno Jean Turcq

Prof. Dr. Mario Sergio de Melo
Assinatura

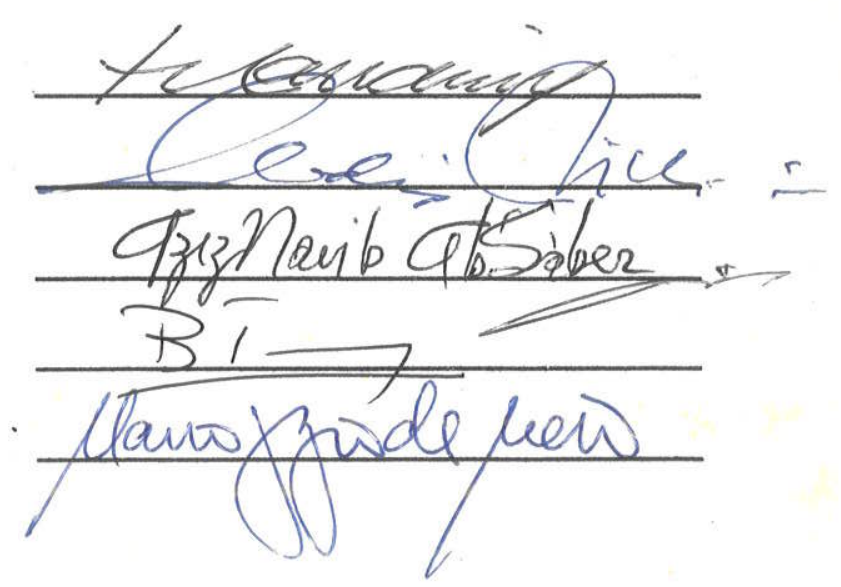

SÃO PAULO 
UNIVERSIDADE DE SĀO PAULO INSTITUTO DE GEOCIENCIAS

\section{ESTUDO DA SEDIMENTAÇĀO NEOGÊNICO-QUATERNÁRIA NO MUNICÍPIO DE SÃO PAULO: CARACTERIZAÇĀO DOS DEPÓSITOS E SUAS IMPLICAÇÕES NA GEOLOGIA URBANA.}

Harmi Takiya

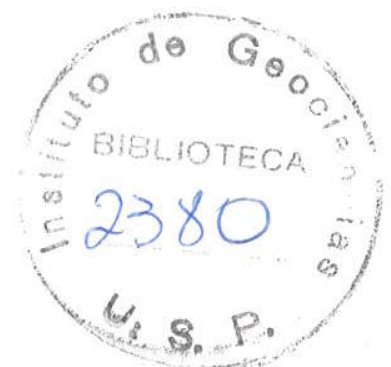

Orientador: Prof. Dr. Paulo Milton Barbosa Landim

TESE DE DOUTORAMENTO

Programa de Pós-Graduação em Geologia Sedimentar

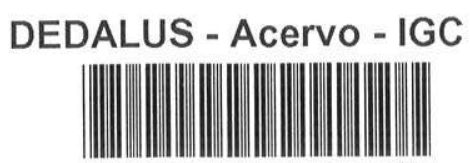

30900009693

SÃO PAULO

1997 
À minha preciosa filha Ágata e aos amigos pelo apoio nos momentos difíceis 
"Pensei que as ciências dos livros, ao menos aquelas cujas razões são apenas prováveis e não se apresentam quaisquer demonstrações, pois se compuseram e avolumaram pouco a pouco com opiniões de mui diversas pessoas, não se acham, de modo algum, tão próximas da verdade quanto os simples raciocínios que um homem de bom senso pode efetuar naturalmente com respeito as coisas que se apresentam"

Descartes (Discurso do Método) 


\section{RESUMO}

São Paulo, uma das maiores cidades do planeta, assenta-se sobre terrenos colinosos da Bacia Sedimentar de São Paulo adentrando também terrenos pré-cambrianos de morros e morrotes ao Norte e ao Sul do município.

Os depósitos sedimentares e formações superficiais da Bacia de São Paulo vem sendo estudados por diversos autores, contribuindo para o acúmulo de conhecimentos - que se mostra atualmente em estágio adiantado -, inclusive do ponto de vista geotécnico. $O$ presente trabalho aborda alguns aspectos significativos desse conhecimento, particularmente no que diz respeito à determinação geocronológica e paleoclimática das coberturas aluviais e coluviais quaternárias, ao comportamento geotécnico dos materiais e da ocorrência de situações de risco geológico-geotécnico relacionados aos depósitos coluviais.

Os depósitos aluviais no Município de São Paulo têm expressiva ocorrência na área, apresentando-se freqüentemente cobertos por camadas de aterro. As idades obtidas sugerem duas fases principais de desenvolvimento de planícies aluviais na área, nos períodos compreendidos: 1) entre 32.000 e 18.000 anos AP; e 2) entre 10.000 anos AP e o presente. A análise palinológica apontou paleoclima seco há cerca de 8.000 anos AP e condições climáticas mais úmidas, próximas das atuais há cerca de 4.000 anos AP.

Já os colúvios, embora pouco descritos na literatura, são depósitos presentes em toda a área, sendo melhor estudados na Zona Sul do município. Na maioria das vezes esses depósitos apresentam stone lines constituídas predominantemente por quartzo, quartzito e fragmentos laterizados, as quais podem representar condições climáticas mais secas. Localmente foram observadas três fases de deposição. As datações radiocarbono efetuadas em fragmentos de carvão situados no topo dos depósitos de colúvio apontaram duas fases de coluvionamento, há $610 \pm 80$ anos AP e há $3.000 \pm 140$ anos AP.

Quanto aos depósitos da Formação Itaquaquecetuba, embora análises palinológicas indiquem idade eomiocênica, considera-se que essa questão ainda não se encontra suficientemente elucidada.

A análise tectônica da área foi efetuada considerando-se informações indiretas, através de mapa de gradientes hidráulicos. Tais mapas sugerem a possibilidade de atuação de atividades neotectônicas (reativações) em estruturas já definidas por outros autores, além de lineamentos com direção NE-SW e NW-SE a sudoeste da área. 
Quanto ao comportamento geotécnico dos depósitos analisados, ressalta-se que a classificação dos solos efetuada através do método MCT (método expedito - $4^{a}$ aproximação) mostrou-se bastante efetiva. Os sedimentos argilosos intemperizados da Formação Resende apresentaram predominantemente comportamento laterítico; entretanto, os depósitos da Formação São Paulo exibiram comportamento não laterítico mostrando caracteristicas mais favoráveis dos primeiros ao uso em obras viárias. Em relação aos depósitos quaternários verifica-se que os colúvios apresentam, em sua grande maioria, comportamento laterítico. No entanto deve-se ressaltar que in situ exibem grande susceptibilidade à erosão, quando saturados.

São apresentados ainda estudo de casos em áreas de risco geológico - geotécnico envolvendo escorregamentos associados à ocorrência de colúvios, exemplificando uma das aplicações da presente pesquisa. 


\begin{abstract}
The city of São Paulo, one of the largest in the world, is located in a sedimentary basin. Covering sedimentary deposits of the São Paulo Basin have been studied by several Authors reaching up now a considerable stage of knowing, including geotechnical approaches. Palinological studies indicate lower Miocene age for Itaquaquecetuba Formation, but some more evidences are needed to prove it.

In the studied area, that means São Paulo County, alluvial deposits have expressive occurrence mainly covered by embankment layers. For the origin of the deposits it is suggested two principal phases of development of alluvial plains: from 32,000 years to 18,000 years BP and 10,000 years from now. Palinological analysis point out dry climate about 8,000 years BP and more humid conditions, like nowadays, about 4,000 years ago.

Colluvial deposits are very common all over the area, but with low citations in the geological literature. They are exhibited mainly in southern part of the area. In the majority of the locations show stone lines constituted by quartz, quartzite, and limonitized lithic fragments. The former could indicate drier climatic conditions. Locally it was observed thee phases of deposition.

Radio-carbon datation from coal collected at the upper part of the colluvial deposits point out two phases: $610+-80$ years ago and $3,000+-140$ years BP.

The tectonic analysis was made throughout indirect information based on hydraulic gradient maps, due to lack of outcrops. Such maps indicate neotectonic processes by reactivation of old structures, already defined by others Authors, and new ones as the NE-SW and NW-SE lineaments. The "domino" features observed in the northern part of the area could indicate dextral strike-slip faults recent in age.

Concerning the geotechnical behavior of the deposits the soil classification, using the MCT method, were plenty effective with the weathered clay sediments from the Resende Formation showing a lateritic behavior. The São Paulo Formation sediments showed a non lateritic behavior, meaning a more favorable condition for use in road construction. Quaternary colluvial deposits show in the majority of the cases lateritic behavior. However "in situ" display, when saturated, great sucebility to erosion.
\end{abstract}


From an urban geology point of view it was applied geological and geotechnical data to case studies and it was find out that the major environmental problems, as slumps, are close related to colluvial deposits. 


\section{AGRADECIMENTOS}

Expresso meus sinceros agradecimentos as pessoas que colaboraram e apoiaram o presente estudo.

Ao Professor Dr. Paulo Milton Barbosa Landim, meu professor de graduação, Orientador de iniciação científica, mestrado e doutoramento, expresso meu reconhecimento e estima pela orientação, incentivo, apoio e confiança.

Ao Professor Dr. Vicente José Fúlfaro pela leitura crítica do presente trabalho. Aos amigos Patrícia Marra Sepe, Alex Ubiratan Goossens Peloggia, Luzia Helena Santos Barros, Antonio Luiz Teixeira e Silvia Sartor pela leitura e revisão do texto, valiosas sugestões e preciosos apoio e amizade.

Aos estagiários da Secretaria Municipal do Verde e Meio Ambiente Eduardo A. Gomes, Graziela Eliane Pepe, Sasha T. Hart, Tiago da R. Karniol, Letícia Cipolotti e Ubiratã Silva pelo inestimável trabalho, apoio e intensa dedicação em diversas fases desse trabalho.

Ao Professor Dr. Claudio Riccomini do Instituto de Geociências da USP, pelas críticas e sugestões efetuadas em diferentes fases do trabalho.

Aos Professores da Escola Politécnica da USP Job Nogami e Liedi Bernucci, e também ao colega, pós-graduando do Instituto de Geociências Helder Godoy, pela transmissão de conhecimentos sobre o método MCT, pelo o apoio nos ensaios executados no Laboratório de Engenharia de Transportes da POLI, além das críticas e sugestões ao trabalho.

Aos Professores Drs. Jean-Pierre Ybert (ORSTOM), Paulo Eduardo de Oliveira (IG-USP) e ao Geólogo Mitsuro Arai (PETROBRAS), pela execução das análises palinológicas e as valiosas discussões e sugestões apresentadas.

Ao Diretor do Departamento de Controle Ambiental da Secretaria Municipal do Verde e Meio Ambiente, Geógr. Yan Roberto Maciel pelo apoio e cessão de dados em diferentes etapas da pesquisa.

A Professora Dr. Vera Cozzolino (POLI - USP) e ao geólogo Hugo Cássio Rocha (METRO) pela cessão de dados de sondagens, críticas e sugestões na área de geotecnia.

Ao Professor Walter Mareschi Bissa do Museu de Arqueologia e Etnologia da USP, pelo apoio, principalmente na preparação de amostras para análise palinológicas. 
Ao Professor Dr. René Boulet do Instituto de Geociências da USP, pelas sugestões sobre colúvios e stone lines.

Aos colegas de pós-graduação Mauro César Geraldes, Elizete Domingos Salvador, Leila Menegassi, Lucy Gomes Sant'Anna, Fernando Mancini, Ana Lucia Gesick, Paulo Boggiani, Jorge Hachiro, Alcina M.F. Barreto, Maria Luiza Oliveira, Roseli Aparecida L. Imbernon, Fresia Ricardi, Sérgio Matos, André Ferrari e Francisco Pinheiro, pelas sugestões apresentadas, pelo apoio e companheirismo.

A Rita Parisi Conde e Márcia Cristina de Ponte pelo apoio nas impressões de mapas, figuras e utilização de microcomputadores.

As amigas da Regional de Campo Limpo, Glória Maria Pereira Rodrigues e Claudete Rosa, pela amizade, apoio e pela cessão de dados sobre áreas de risco geológico-geotécnico.

Aos amigos da Secretaria Municipal do Verde e Meio Ambiente, Carlos Alberto Leonardi, Francisco Adrião N. da Silva, Sylvia Damião, Fernando A. Tavares, José Luiz T. dos Santos, Roseli de Oliveira, Margarete Maeda e Roseli Affonso pelo apoio, incentivo e amizade.

A Companhia de Pesquisas e Recursos Minerais, pelo apoio em diversas etapas desse trabalho, principalmente na utilização de microcomputadores.

Ao geólogo Sérgio Kleinfelder Rodriguez, pelo apoio fundamentalmente nas etapas iniciais desse trabalho.

Ao Conselho Nacional de Desenvolvimento Científico e Tecnológico - CNPq pela bolsa de estudos fornecida no período de 1991 a 1994, e à Fundação de Amparo a Pesquisa do Estado de São Paulo (Processo 93/4499-4) pela cessão de auxilio à pesquisa.

Agradeço por fim, ao meu pai (in memoriam), a minha mãe e aos meus irmãos, pelo incalculável apoio a esse trabalho. 
ESTUDO DA SEDIMENTAÇÃO NEOGÊNICO - QUATERNÁRIA NO MUNICÍPIO dE SÃo PAULO: CARACTERIZAÇ̃̃o dOS DEPóSITOS E SUAS IMPLICAÇÕES NA GEOLOGIA URBANA.

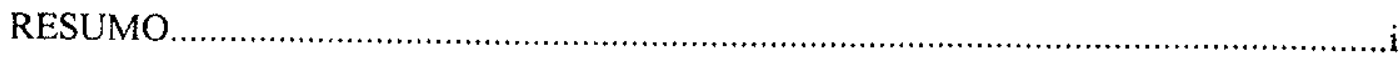

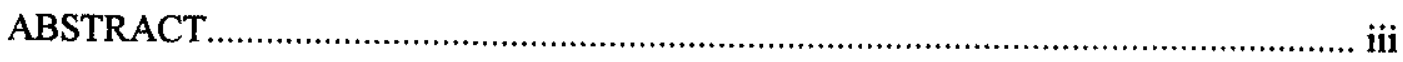

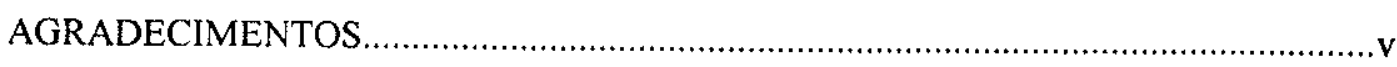

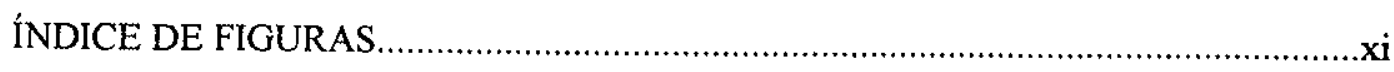

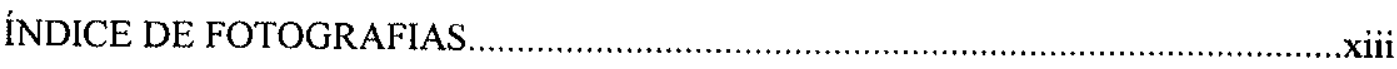

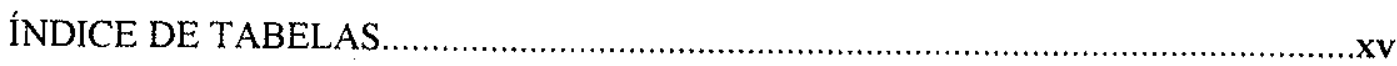

\section{CAPÍtulo 1}

\section{INTRODUÇÃO}

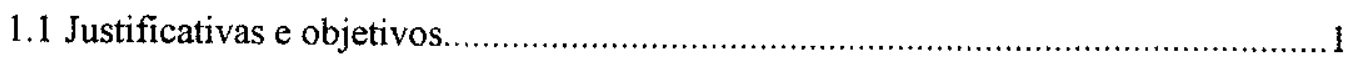

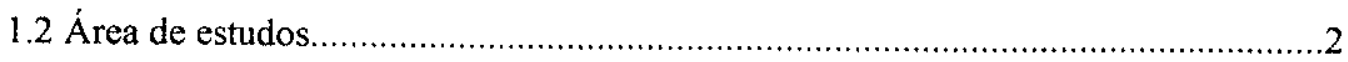

\section{CAPÍtulo 2}

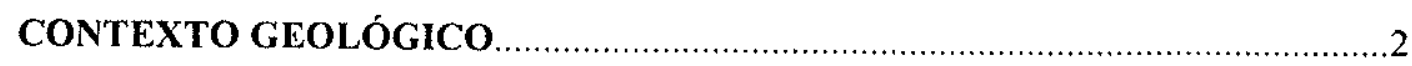

\section{CAPÍTULO 3}

MÉTODOS E TÉCNICAS UTILIZADAS ..........................................................

3.1 Coleta de dados e levantamentos de campo ......................................................

3.2 Classificação geotécnica de solos..................................................................

3.2.1 Classificaçăo geotécnica - MCT, Miniatura, Compactado, Tropical...........9

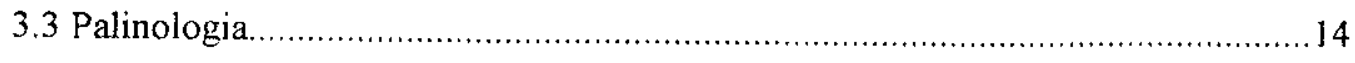

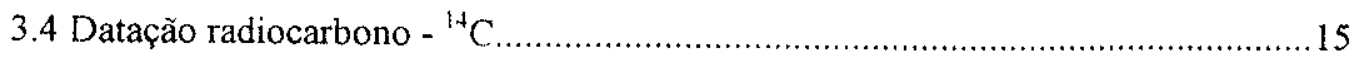


3.5 Difratometria de Raios X.

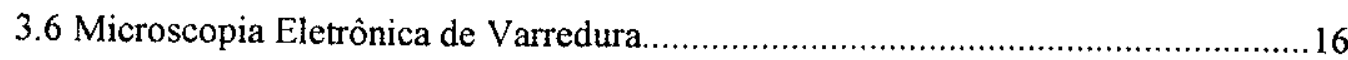

3.7 Análise petrográfica de seções delgadas......................................................... 16

3.8 Mapa de gradientes hidráulicos ..................................................................17

\section{CAPÍtULO 4}

CONTEXTO GEOMORFOLÓGICO E GEOLÓGICO DA BACIA DE SÃo PAULO

4.1 Aspectos geomorfológicos. 18

4.2 Bacia de São Paulo

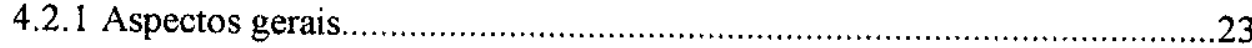

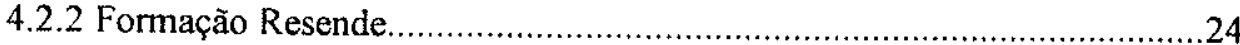

4.2.3 Formação Tremembé ...........................................................................38

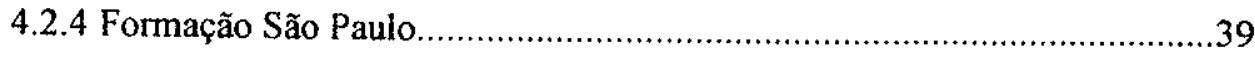

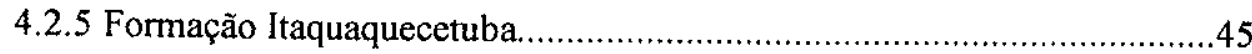

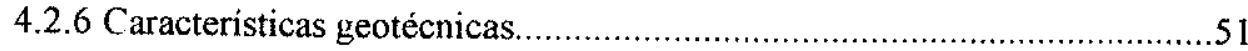

\section{CAPítulo 5}

\section{COBERTURAS QUATERNÁRIAS}

5.1 Introduçăo 57

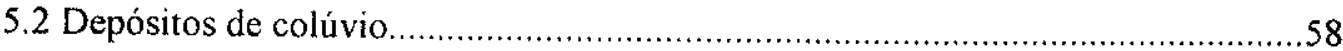

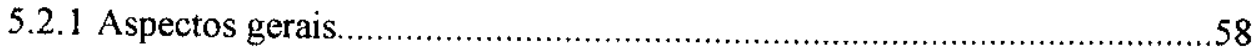

5.2.2 Depósitos de colúvio presentes na área de estudo....................................59

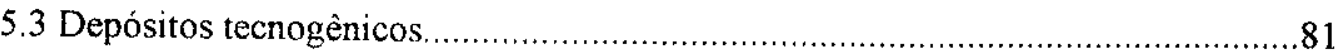

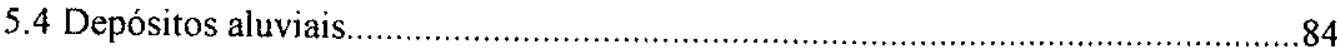

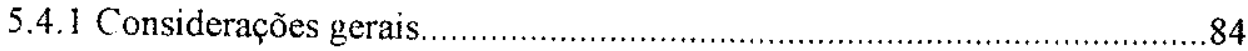

5.4.2 Dataçōes radiocarbono e análises palinológicas......................................88 


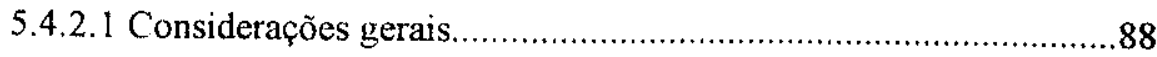

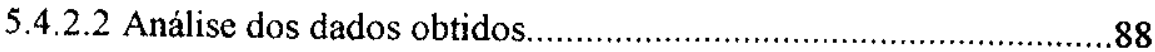

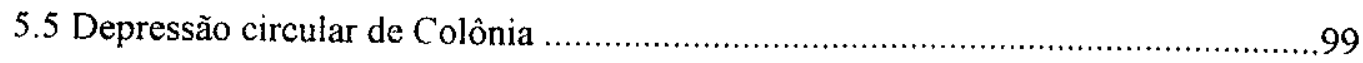

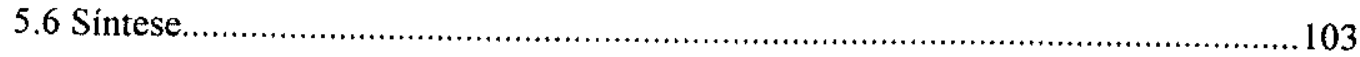

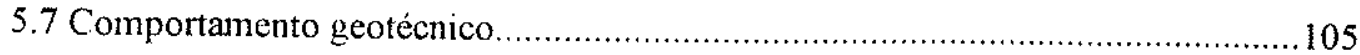

\section{CAPÍTULO 6}

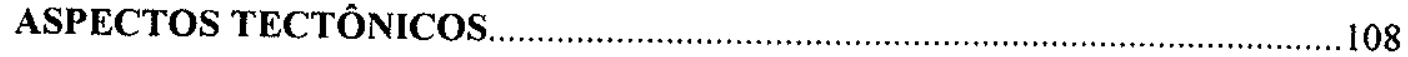

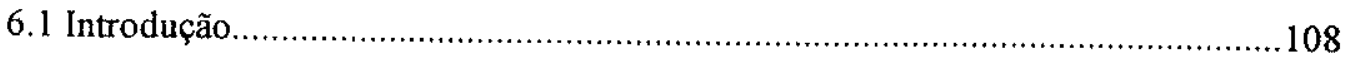

6.2 Análise dos mapas de gradientes hidráulicos..................................................109

\section{CAPítulo 7}

GEOLOGIA URBANA

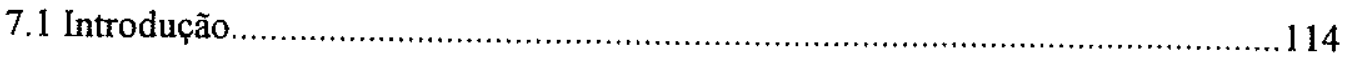

7.2 Principais problemas ambientais do municipio................................................ 115

7.3 Estudos de casos em áreas de risco geológico - geotécnico................................118

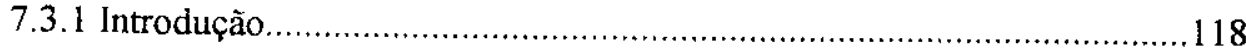

7.3.2 Jardim Paranapanema................................................................. 120

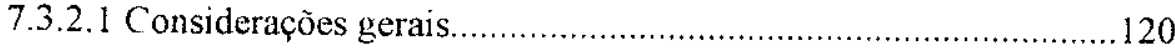

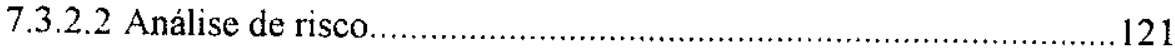

7.3.3 Jardim Capelinha................................................................... 127

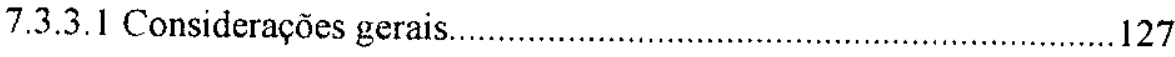

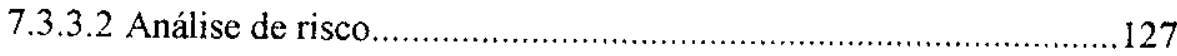

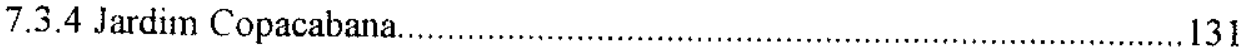

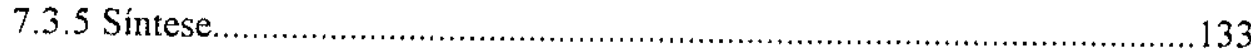




\section{CAPÍTULO 8}

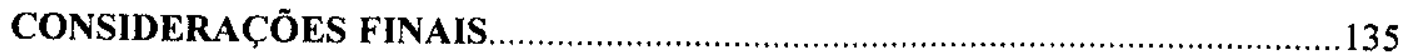

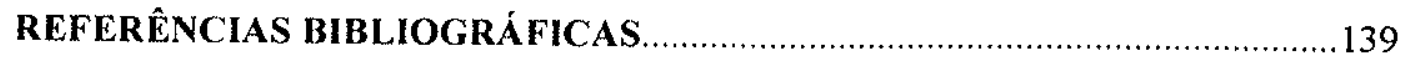

APÊNDICE 
Indice de Figuras

Figura 1 - Mapa de localização da área de estudo. 3

Figura 2 - Contexto geológico e tectônico regional .................................................................

Figura 3 - Gráfico da classificação MCT ...................................................................... 11

Figura 4 - Divisão geomorfológica do Estado de São Paulo........................................................19

Figura 5 - Seção morfológico-estrutural da Serra da Cantareira ...............................................220

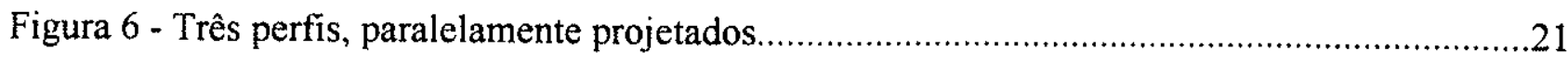

Figura 7 - Relações entre a litoestratigrafia e a tectônica..........................................................24

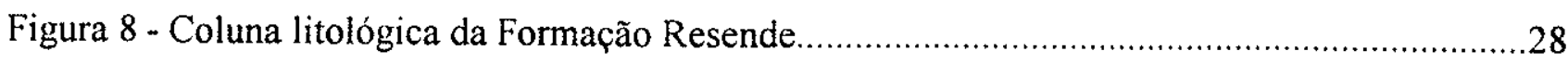

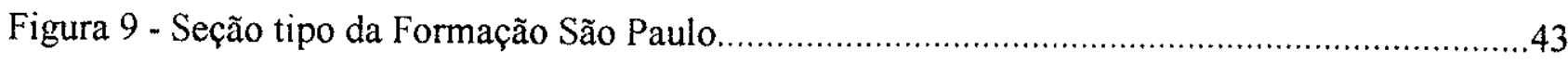

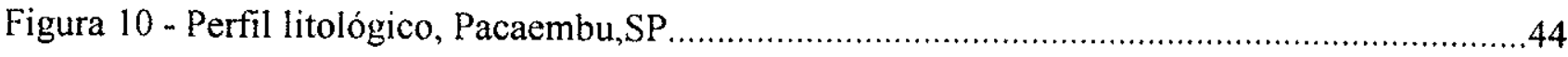

Figura 11 - Seção tipo da Formação Itaquacetuba (RICCOMINI 1989) ......................................46

Figura 12 - Descrição de sedimentos da Formação Itaquacetuba ................................................48

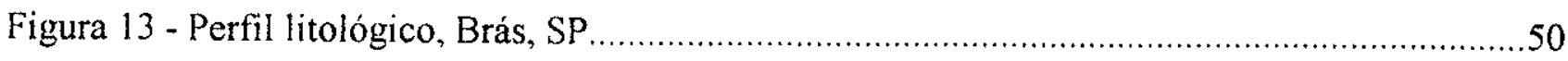

Figura 14 - Perfil litológico. Rua Eirunepê,

Figura 15 - Perfil litológico. Rua Miguel Lobo, Zona Leste......................................................67

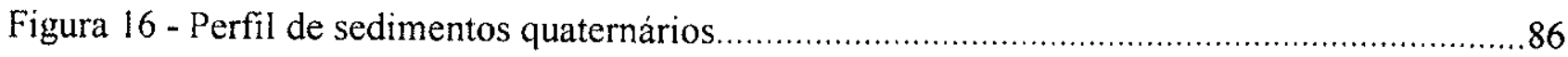

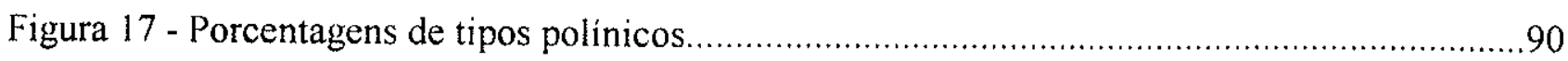

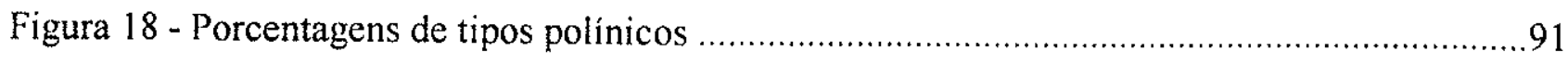

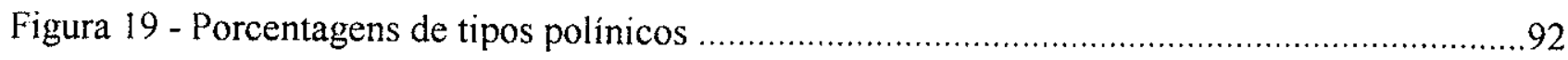

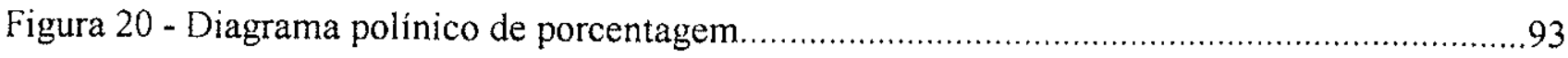

Figura 21 - Diagrama polínico de concentração.............................................................. 94

Figura 22 - Diagrama polínico de concentração................................................................. 95

Figura 23 - Geologia da área do Astroblema de Colônia ...................................................... 100 
Figura 24 - Correlação entre a sedimentação quaternária..

Figura 25 - Mapa de localização de pontos 110

Figura 26 - Mapa de isovalores de gradientes hidráulicos.

Figura 27 - Mapa de isovalores de gradientes hidráulicos.

Figura 28 - Mapa de setorização de risco, Jd Parapanema. 122

Figura 29 - Setorização de risco, Jd Capelinha,.... 128 
Índice de Fotografias

Fotografia 1 - Ensaio para classificação MCT, Método Expedito .................................................12

Fotografia 2 - Ensaio para classificação MCT, Método Expedito.................................................. 12

Fotografia 3 - Testemunhos de sondagem executada no Parque do Piqueri, SP ..........................26

Fotografia 4 - Testemunhos de sondagem. Parque do Piqueri, SP.............................................27

Fotografia 5 - Testemunhos de sondagem executada na Rua Colômbia, SP.................................29

Fotografia 6 - Areia conglomerática da Formação Resende .......................................................30

Fotografia 7 - Grão de turmalina envolto por matriz argilosa ................................................

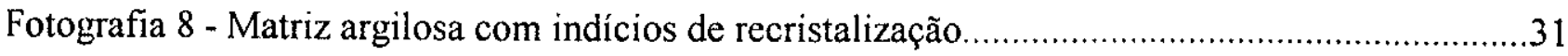

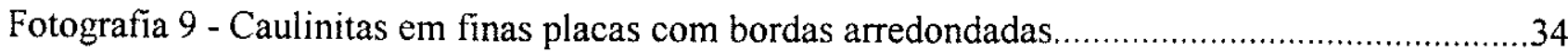

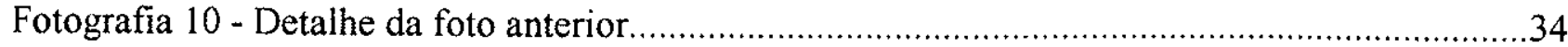

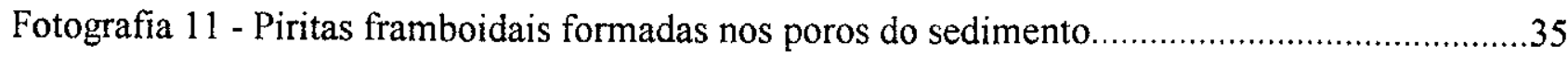

Fotografia 12 - Caulinitas em finas placas com bordas arredondadas. MEV ..............................35

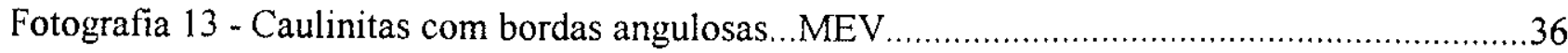

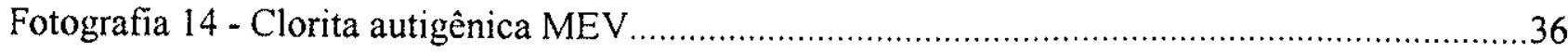

Fotografia 15 - Finas placas de caulinita com bordas arredondadas...MEV ..................................37

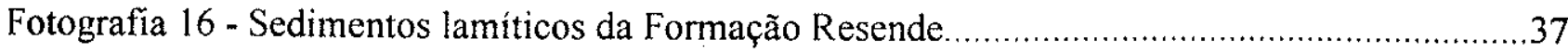

Fotografia 17 - Obra para construção do Reservatório da Praça Charles Muller.............................40

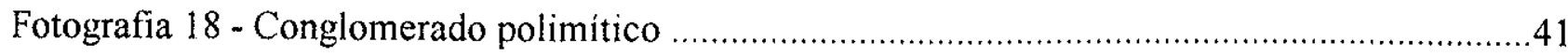

Fotografia 19 - Obra para construção do Reservatório da Praça Charles Müller.............................41

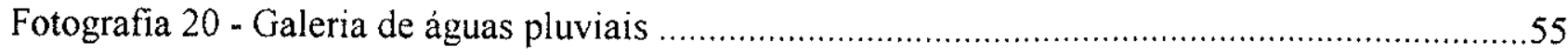

Fotografia 21 - Colúvio de coloração marrom, com matriz argilo-arenosa .................................62

Fotografia 22 - Colúvio marrom-claro...Rua dos Antípodas, Campo Limpo...............................62

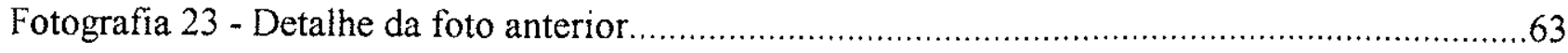


Fotografia 24 - Colúvio marrom-amarelado...Rua Nova Tuparoquera.

Fotografia 25 - Detalhe da foto anterior

Fotografia 26 - Colúvio de coloração marrom-acastanhado

Fotografia 27 - Camada de colúvio onde é destacado a Stone line. .66

Fotografia 28 - Colúvio de coloração marrom-acastanhado .68

Fotografia 29 - Grãos de quartzo angulosos....Fotomicrografia.

Fotografia 30 - Grãos de quartzo de dimensões variadas...Fotomicrografia.

Fotografia 31 - Grãos de quartzo angulosos e subangulosos...Fotomicrografia. .69

Fotografia 32 - Colúvio apresentando matriz argilosa ...Fotomicrografia. 70

Fotografia 33 - Grãos de quartzo e quartzitos...Fotomicrografia. 70

Fotografia 34 - Grãos sustentados por matriz argilosa...Fotomicrografia. 71

Fotografia 35 - Fragmento lítico de quartzo...Fotomicrografia. 71

Fotografia 36 - Colúvio apresentando predominantemente grãos de quartzo. 72

Fotografia 37 - Detalhe da foto anterior 72

Fotografia 38 - Grãos de titanita...Fotomicrografia. 73

Fotografia 39 - Fragmento laterizado...Fotomicrografia. 73

Fotografia 40 - Caulinita com forma pacóide...MEV. 74

Fotografia 41 - Detalhe da foto anterior.

Fotografia 42 - Afloramento apresentando três gerações de colúvio 78

Fotografia 43 - Afloramento apresentando duas gerações de colúvio 79

Fotografia 44 - Depósitos aluviais argilosos cobertos por aterro. 82

Fotografia 45 - Favela do Jardim Sandra... Área de antigo bota-fora. 82

Fotografia 46 - Favela Peinha, Campo limpo...Escorregamento. 83

Fotografia 47 - Caulinitas em placas com bordas irregulares. 87 
Fotografia 48 - Área da estrutura circular de Colônia, Zona Sul.

Fotografia 49 - Vista panorâmica da Zona 1. Jardim Parapanema..

Fotografia 50 - Rua Andrea Sansovino, Setor 2, Jardim Parapanema.

Fotografia 51 - Vista de talude a partir da Rua Andrea Sansovino

Fotografia 52 -Talude de corte situado no Setor 1

Fotografia 53 -Talude de alta declividade Setor 1. 129

Fotografia 54 - Visão panorâmica da Favela Copacabana 132

Índice de Tabelas

Tabela 1 - Locais de coletas de amostras para datação e análise palinológica. 14

Tabela 2 - Principais palinomorfos nas amostras de sondagem na Raia Olímpica da USP. 51

Tabela 3 - Resultados dos ensaios MCT. 52

Tabela 4 -Carência habitacional no município de São Paulo 118

Tabela 5 - Locais de ocorrência de escorregamento associado a colúvio. 134

\section{ANEXOS}

Anexos A - Mapa geológico, Bacia de São Paulo

Anexos B - Mapa de isovalores de gradientes hidráulicos e estruturas tectônicas

Anexos C - Perfil de sondagens, córrego Franquinho 


\section{CAPítulo 1}

\section{INTRODUÇÃO}

\subsection{JUSTIFICATIVAS E OBJETIVOS}

A cidade de São Paulo, com seus 443 anos de história, experimenta na década de 90 uma diminuição na taxa de crescimento populacional, mas que não afeta a diversidade dos problemas hoje por ela enfrentados. Frente a frente com contradições de diversas magnitudes e convivendo com situações de miséria e degradação da qualidade de vida, o cidadão paulistano vem tentando aprender a conviver com a violência urbana, por mais que isso lhe custe.

O censo de 1990 (IBGE 1991) mostrou que naquele ano São Paulo abrigava 4.644.876 homens e 4.982.018 mulheres, distribuídos em seus 7009 bairros, ocupando uma área de $1509 \mathrm{~km}^{2}$.

O déficit habitacional, resultante da queda do poder aquisitivo, a deficiência de programas de habitação de baixa renda e o êxodo rural, fez com que no período de 1973 a 1987 o número de população favelada aumentasse em mais de $2540 \%$, conforme dados oficiais (SEHAB 1995). Hoje vivem ou sobrevivem em São Paulo mais de 1.900 .000 favelados concentrados na periferia, principalmente na Zona Sul da cidade (SEHAB 1995).

Áreas consideradas como non aedificundi pelos planejadores da cidade, como margens de córregos, proibidas também à ocupação pela Lei de Proteção aos Mananciais, são justamente as escolhidas por esta população excluída, pois tratam-se na sua grande maioria de áreas públicas, que incluem também terrenos de alta declividade, comumente superiores a $60 \%$, onde são construídas moradias em precarissimas condições técnicas e sanitárias.

Proliferam-se assim as denominadas "áreas de riscos", à proporção da instalação e consolidação da miséria nas porções mais periféricas da cidade, desprovidas de condições mínimas de infra-estrutura urbana, onde também já são identificados conflitos entre algumas das 34 minerações hoje ativas no municipio e a população aí existente.

São Paulo, incluída entre as cinco maiores cidades do planeta, ostenta também, é claro, a opulência de uma metrópole que ainda procura espaços para crescer. Recentes estudos realizados em megacidades da Europa (MULDER 1993) apontam os mesmos problemas verificados na cidade de São Paulo, como enchentes, escorregamentos e poluição das águas subterrâneas. Isto ressalta que a área do conhecimento definida como Geologia Urbana reveste-se atualmente de grande 
importância, tendo em vista que no ano 2000 pelo menos a metade da população do planeta, estimada em 7 bilhões de habitantes, estarão vivendo em áreas urbanas.

Estudos de síntese, que possam contribuir no sentido de melhor caracterizar a geologia dos depósitos sedimentares e formações superficiais mais recentes, seu comportamento e propriedades geotécnicas, ainda são carentes, no âmbito do município. Paradoxalmente, a cada dia, um considerável número de informações pontuais é produzido na cidade, quer seja pela implantação de inúmeras obras de diferentes magnitudes, quer seja através das muitas sondagens executadas ou poços perfurados para água subterrânea. Certamente foram essas as fontes significativas de informação para a confecção deste trabalho.

O presente trabalho tem como objetivo o estudo da sedimentação neogênico-quaternária no Município de São Paulo. Os principais tópicos desenvolvidos referem-se a caracterização desses depósitos, discussão de idades e inferências paleoclimáticas principalmente no Quaternário, além da apresentação de ensaios e características geotécnicas dos depósitos estudados. Aplicações na geologia urbana, principalmente em áreas de risco geológico-geotécnico associadas a ocorrências de escorregamentos envolvendo depósitos de colúvio são ainda apresentados, visando contribuir, entre outros aspectos, ao planejamento do uso e ocupação do solo na cidade.

\subsection{LOCALIZAÇÃO DA ÁREA ESTUDADA.}

A área de estudo corresponde aos limites geográficos que delimitam o Municipio de São Paulo, situando-se entre as coordenadas 313 a 361 km (E) e 7344 a 7416 km (N) na Unidade Transversal de Mercator (UTM), origem no Equador e Meridiano Central $45^{\circ}$ WGR, acrescidas as constantes $10.000 \mathrm{~km}$ e $500 \mathrm{~km}$ respectivamente (Figura 1).

\section{CAPÍtulO 2}

\section{CONTEXTO GEOLÓGICO REGIONAL}

A Bacia Sedimentar de São Paulo insere-se no contexto do Sistema de Rifts Continentais da Serra do Mar, definido por ALMEIDA (1976), composto pelas bacias de Curitiba, São Paulo, Taubaté, Resende e Volta Redonda. RICCOMINI (1989) modificou esse termo para Rifi Continental do Sudeste do Brasil - RCSB, o qual teria significado genético, englobando no mesmo 


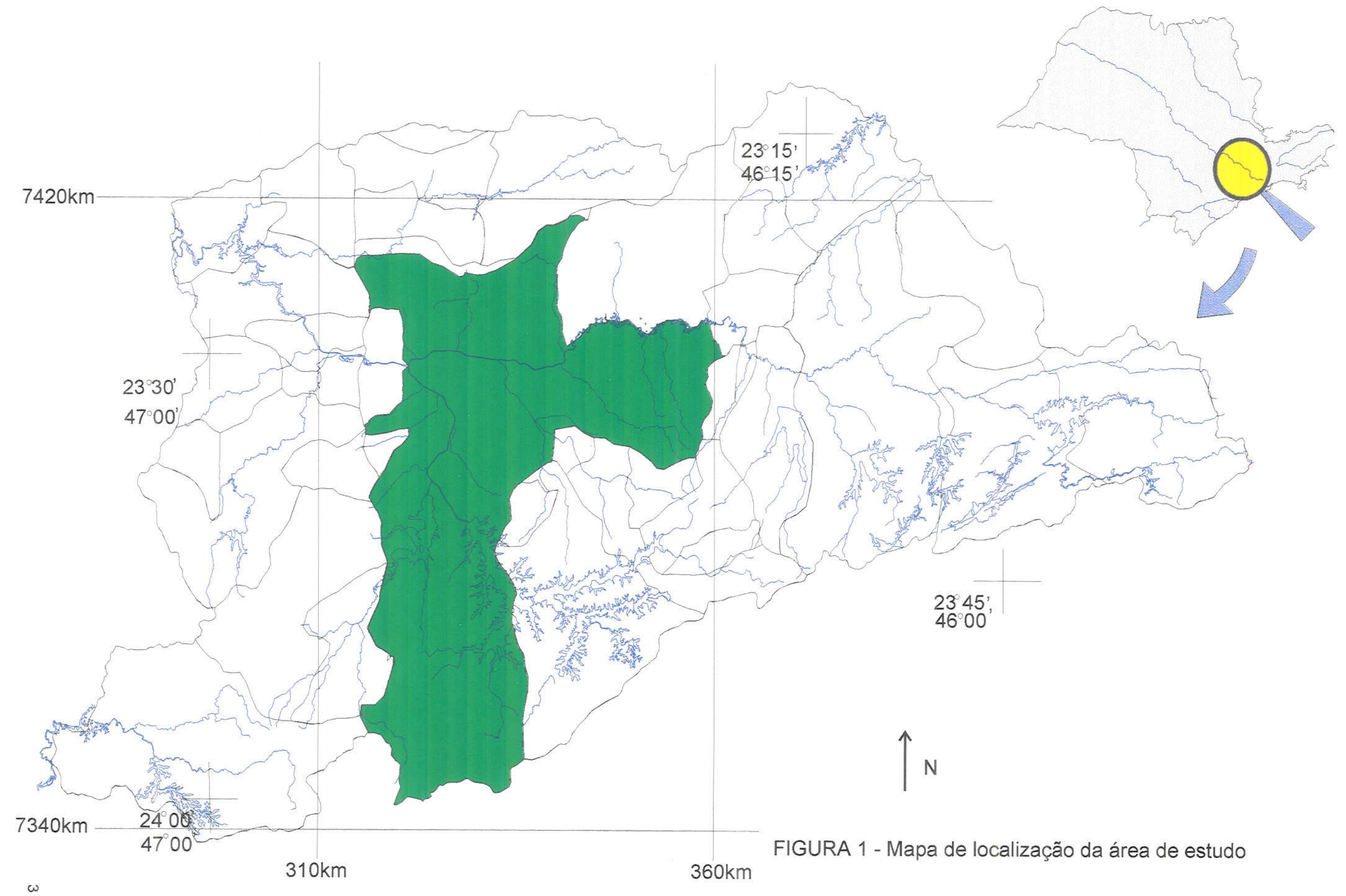


contexto ainda as bacias de Itaboraí e Bonfim e o Graben de Sete Barras (MELO et al. 1989a).

Posteriormente RICCOMINI \& COIMBRA (1992) inseriram no RCSB o (jraben de Barra de São João (MOHRIAK \& BARROS 1990) e o Graben Guaraqueçaba (RICCOMINI \& COIMBRA 1992) (Figura 2).

O Rifi Continental do Sudeste do Brasil insere-se, assim, no contexto geomorfológico denominado Planalto Atlântico (AZEVEDO 1949) que corresponde a porção oriental do Planalto Brasileiro (AZEVEDO 1949). Na área do território paulista, segundo ALMEIDA (1958), o Planalto Atlântico corresponde a terrenos mais ou menos acidentados, com altitudes variando entre 650 a $1250 \mathrm{~m}$, e com estruturas complexas e feições como planícies aluviais, colinas, morros e serras de traçado linear.

ALMEIDA (1958) considerou a existência de diferentes unidades fisiográficas no Planalto Atlântico, mas que muitas vezes não apresentam limites rigorosamente definidos. Entretanto, uma das unidades bem caracterizadas corresponde ao Planalto Paulistano, onde assenta-se a cidade de São Paulo.

Trabalhos recentes mostram a adoção da caracterização do Rift Continental do Sudeste do Brasil por diversos autores (e.g. TAKIYA 1991; CAMPANHA et al 1991.; ROCHA \& CELESTINO 1992; SALVADOR 1994; COZZOLINO et al. 1994) mostrando a boa aceitação do termo, assim como, na maioria dos casos, da revisão estratigráfíca e do modelo estrutural proposto por RICCOMINI (1989) para as principais bacias do rifi.

O rift dispõe-se segundo uma extensa faixa de cerca de $900 \mathrm{~km}$, orientada segundo E-NE, paralela a atual linha de costa. $O$ arcabouço estrutural das bacias do RCSB configura semigrabens basculados para NNW, conforme disposição retilínea.

Na Bacia de São Paulo, os mapas de contorno estrutural do topo do embasamento sugerem uma compartimentação em blocos, com cotas mais baixas situadas ao longo da borda norte da bacia (HASUI \& CARNEIRO 1980; TAKIYA et al. 1989; TAKIYA 1991).

O embasamento pré-cambriano dessas bacias inclui-se no denominado Cinturão de Dobramentos Ribeira (HASUI el al. 1975) constituído por rochas metamórficas (gnaisses, xistos, filitos, anfibolitos, quartzitos, milonitos-gnaisses, blastomilonitos, milonitos, etc), migmatitos com 


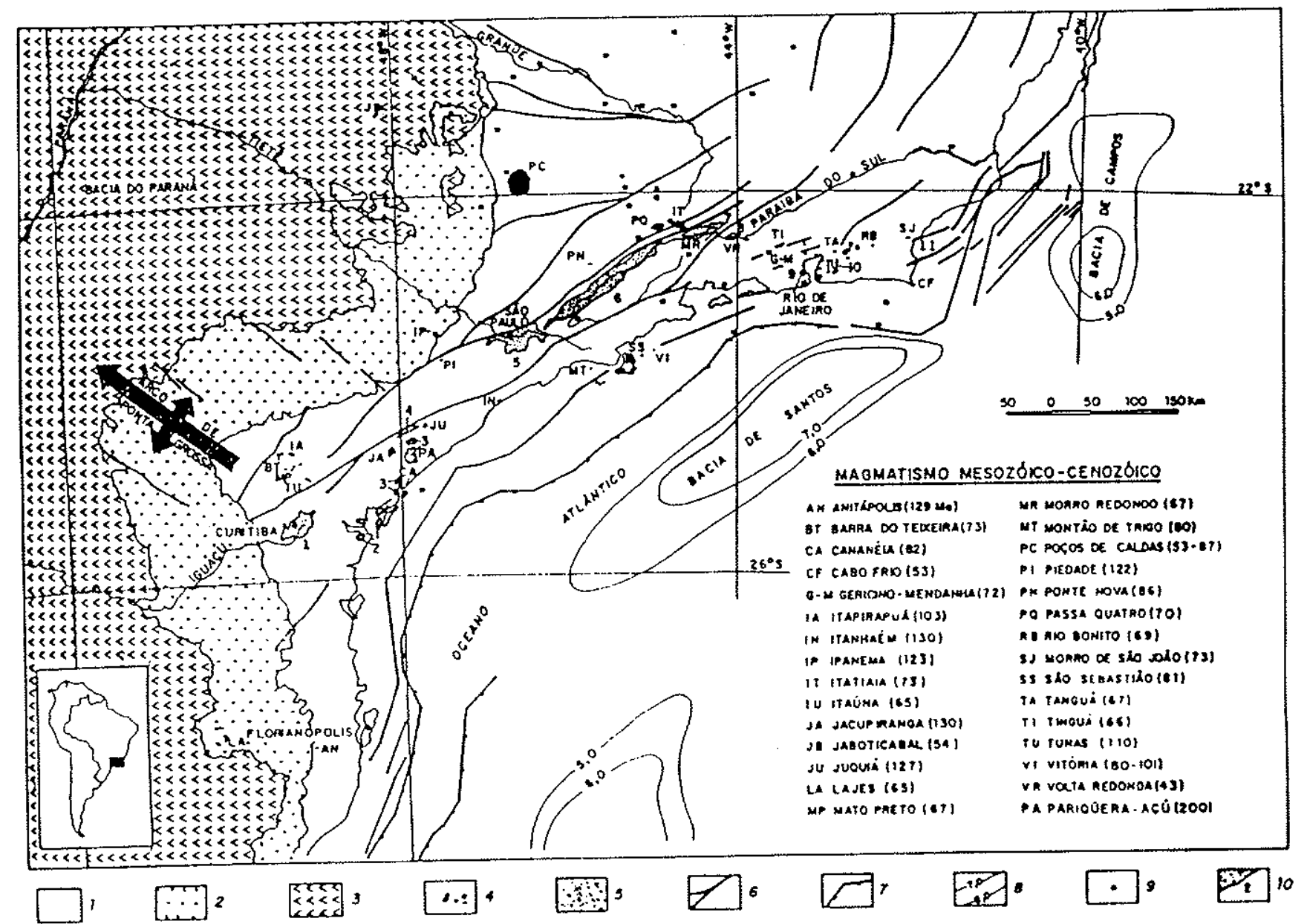

LEGENDA: 1. Embasamento pré-Cambriano; 2. Sedimentos paleozóicos e mesozóicos da Bacia do Paraná; 3. Rochas relacionadas ao vulcanismo da Formação Serra Geral em partes recobertas por sedimentos e, nestes últimos, algumas intecalaçöes de lavas alcalinas; 4 . Rochas relacionadas ao magmatismo Mesozóico-Cenozóico (ver quadro no interior da Figura; idades em Ma entre parênteses); 5 . Sedimentos terciários; 6 . Zonas de cisalhamento

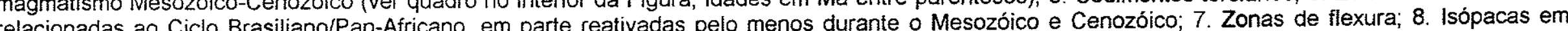
relacionadas ao Ciclo Brasiliano/Pan-Africano, em parte reativadas pelo menos durante o Mesozóico e Cenozoico; 7 Formação Alexandra e Graben de kilômetros, dos sedimentos das bacias costeiras; 9 . Epicentros de terremotos; 10. Bacia do rift (1-Bacia de Curitiba; 2 Formação Alexandra, e Graben de
Guaraqueçaba, 3-Formação Parique-Açu; 4-Graben de Sete Barras; 5-Bacia de São Paulo; 6-Bacia de Taubaté; 7-Bacia de Resende; 8-Bacia de Volta Redonda;9 Graben da Guanabara; 10-Bacia de Itaboraí; 11-Graben de Barra de São Joäo).

Figura 2. Contexto geológico e tectônico regional do rift Continental do Sudeste do Brasil (RICCOMINI \& COIMBRA 1992). 
estruturas variadas e rochas granitóides diversas referentes ao Ciclo Tectônico Brasiliano ou oriundas de retrabalhamento de rochas de ciclos mais antigos.

A área do rifi é intensamente recortada por falhamentos transcorrentes de caráter dextral e direção ENE a EW, que permaneceram ativos até o final do Ciclo Brasiliano, no CambroOrdoviciano, originando espessas faixas cataclásticas (SADOWSKI 1983; HASUI \& SADOWSKI 1976, SADOWSKI \& MOTIDOME 1987; SADOWSKI 1991). Evidências de reativações dessas estruturas no Cenozóico e ainda registros de atividades neotectônicas no Rift Continental do Sudeste do Brasil são mostradas nos trabalhos de RICCOMINI et al. (1989), MANCINI \& RICCOMINI (1994), SALVADOR (1994) e SALVADOR \& RICCOMINI (no prelo).

ASMUS \& FERRARI (1978) consideram o tectonismo cenozóico incomum no modelo clássico de evolução de uma margem continental do tipo Atlântico; entretanto tais autores atribuem essas atividades tectônicas a ocorrências de desequilíbrio isostático entre a Bacia de Santos e a região continental adjacente, imprimindo nessas áreas movimentos verticais opostos que culminaram na ruptura crustal. Essa hipótese tem sido aceita para explicar a origem do rift (MELO et al. 1985; RICCOMINI 1989; RICCOMINI \& COIMBRA 1992).

Estudos palinológicos realizados nas bacias de São Paulo, Taubaté e Resende e datações efetuadas em ankaramitos da Bacia de Volta Redonda indicaram que a principal fase de sedimentação das bacias ocorreu durante o Oligoceno (MELO et al. 1985; RICCOMINI 1989), havendo ainda indicações de registros sedimentares mais antigos. 


\section{CAPÍtuLO 3}

\section{MÉTODOS E TÉCNICAS UTILIZADAS}

\subsection{COLETA DE DADOS E LEVANTAMENTOS DE CAMPO}

A primeira fase deste trabalho compreendeu o agrupamento e análise do material bibliográfico e cartográfico disponivel para a área de estudos. Foram analisados ainda diversos relatórios e projetos de obras executados pela Prefeitura do Município de São Paulo, além de centenas de boletins de sondagens à percussão.

O trabalho de campo consistiu no acompanhamento a obras de pequeno, médio e grande porte, particulares ou realizadas por instituições públicas. Foram visitados ainda diversos afloramentos, expostos principalmente em taludes de corte, comumente situados ao longo de vias, loteamentos, áreas de planície aluvial etc. Nestes locais foram elaborados perfis estratigráficos, efetuados mapeamentos de litofácies, coletadas amostras de solo e rocha, dados estruturais e realizada a documentação fotográfica.

Efetuou-se ainda nesse trabalho sondagens ( a trado, percussão e rotativa ) com coleta de testemunhos contínuos para descrição litológica detalhada e coleta de amostras para análises e ensaios de laboratório.

\subsection{CLASSIFICAÇ̃̃O GEOTÉCNICA DE SOLOS}

As regiões tropicais apresentam uma grande variedade de solos que se desenvolvem condicionados a fatores ambientais da superficie, conferindo-lhes propriedades peculiares, inclusive do ponto de vista geotécnico.

Segundo NOGAMI \& COZZOLINO (1985) dentre as características peculiares dos solos tropicais, pode-se citar a agregação da fração fina dos solos lateriticos, devido à cimentação por óxidos hidratados de Fe e/ou Al. Essa característica imprimirá diferentes valores aos resultados de ensaios para determinação da granulometria e dos limites de Atterberg, dependendo do método empregado na destruição desses agregados. 
VARGAS (1982) considerou que os limites de Atterberg só serão aplicáveis quando "tanto as normas de ensaio como as de preparação das amostras para determinação desses índices sejam muito bem estabelecidas e acordadas"

COZZOLINO E NOGAMI (1993) referiram-se a ensaios efetuados por diversos autores, nos quais são demonstrados que o uso de diferentes defloculantes ou o não uso dos mesmos, em classificações granulométricas, pode levar a resultados distintos. Da mesma forma, um incremento no tempo de manipulação no preparo para ensaio de solos lateríticos pode influenciar sensivelmente os valores de limite de liquidez dos obtidos.

Outra particularidade importante observada por NOGAMI \& COZZOLINO (1985) é a presença de macrocristais de mica e caulinita nos solos saprolíticos, principalmente na fração silte desses. Desta forma, mesmo não apresentando a fração argila, os solos saprolíticos poderão exibir plasticidade. A presença de mica na fração areia também poderá ocasionar modificações nos índices de plasticidade - IP e limites de liquidez - LL, conferindo muitas vezes aos solos saprolíticos, comportamento distinto do esperado.

SÓRIA (1986) relatou que as classificações tradicionais são falhas, pois os ensaios de LL e LP são incapazes de identificar solos tropicais diversos. Eles não distinguem nem a natureza nem os teores dos argilominerais. Segundo o autor, "Os ensaios medem efeito combinado de no mínimo três frações diversas. A maneira como o ensaio combina esses efeitos, e também os próprios efeitos separados, pode-se dizer que ainda são desconhecidos. Há incerteza também quanto aos limites que separam cada fração e ao próprio uso da separação granulométrica para identificar as frações que têm efeitos diversos".

ROCHA (1995) apontou também problemas observados na utilização da classificação granulométrica e do Sistema Unificado de Classificação de Solos, fazendo uma comparação entre os dois métodos. O autor propôs para os "solos terciários" da Bacia de São Paulo um sistema de classificação híbrido, associando os dois métodos mencionados, válido para solos com mais de $50 \%$ de areia em peso.

O relatório do Geological Society Engineering Geology Working Party (1990) considerou os solos tropicais como uma categoria especial e não recomenda a correlação do limite de liquidez com outros parâmetros de solo. Estabeleceu ainda que a difração de Raios X é indispensável para a identificação da mineralogia dos solos tropicais. 
No entanto, NOGAMI \& VILLIBOR (1996) lamentaram o fato de que o relatório citado adote uma terminologia imprópria e confusa para solos tropicais, sem distinção entre os solos saprolíticos e os solos de alto grau de laterização. Os autores questionaram ainda a identificação mineralógica por difração de Raios $X$, pois o método exige especialização e equipamentos sofisticados, pouco disponíveis nos laboratórios geotécnicos.

Dessa forma, para a identificação desses solos, métodos tradicionais como o Sistema Unificado de Classificação de Solos - USCS e o sistema HRB-AASHO, que se baseiam em propriedades como granulometria e plasticidade, podem não se mostrar tão efetivos quando trata-se de solos tropicais (NOGAMI \& VILLIBOR 1980; COZZOLINO \& NOGAMI 1993).

Neste trabalho adotou-se o método MCT- Miniatura, Compactado, Tropical, detalhado no próximo item, uma vez que os materiais amostrados são constituídos principalmente por solos superficiais submetidos, em maior ou menor grau à exposição a processos pedogenéticos (colúvios, solos de alteração de rochas do embasamento e da bacia), onde o comportamento geotécnico é caracterizado quanto ao grau de laterização. A escolha foi efetuada também por tratar-se de um ensaio relativamente simples, de fácil execução e cujos resultados tem eficácia comprovada $(e . g$. FERREIRA et al. 1987; GODOY et al. 1996).

\subsubsection{CLASSIFICAÇÃo GEOTÉCNICA - MCT, MiNiATURA, COMPACTAdO, TROPICAL.}

A classificação geotécnica MCT para solos tropicais, inicialmente proposta por NOGAMI \& VILLIBOR (1981), consideraram duas classes de solos: os de comportamento "laterítico"e aqueles de comportamento "não laterítico". Desde então, o método tem sido constantemente aperfeiçoado (NOGAMI \& COZZOLINO 1985; VERTAMATTI 1988; FORTES 1990; FORTES \& NOGAMI 1991; IGNATIUS 1991; NOGAMI \& VILLIBOR 1996).

Essa classificação foi desenvolvida inicialmente para utilização em obras de pavimentação de baixo custo. Atualmente propõe-se que o método tenha uso mais abrangente.

A classificação MCT baseia-se na determinação de dois coeficientes, c', d' e um índice e' ( figura 3). Os coeficientes são obtidos através de ensaio de compactação, com corpos de prova de 
dimensões reduzidas, segundo o procedimento MINI-MCV (NOGAMI \& VILLIBOR 1985), que fornecem curvas de deformabilidade e de compactação.

O índice e' é definido pela expressão:

$\mathbf{e}^{\prime}=\left[\left(20 \mathbf{d}^{\prime}\right) /+(\mathbf{P i} / 100)\right]$

onde:

d'= inclinação do ramo seco da curva de compactação correspondente a 12 golpes quando a massa especifica aparente seca é expressa $\mathrm{em} \mathrm{kg} / \mathrm{m}^{3}$, e a umidade em porcentagem.

$\mathrm{Pi}=$ perda de massa por imersão total em água de corpos de prova de dimensões padronizadas. Expresso em porcentagem.

Por ser considerada muito trabalhosa, a determinação desses parâmetros ainda representa um empecilho para uma maior aceitação do método, principalmente por profissionais que atuam em áreas diferentes das de pavimentação e obras viárias (NOGAMI \& VILLIBOR 1994). Para a obtenção de c' e Pi, necessita-se de um compactador especial para a moldagem de pelo menos 4 corpos de prova, que consomem cerca de $1200 \mathrm{~g}$ de solo com granulometria menor que $2.0 \mathrm{~mm}$. São gerados assim, cerca de 150 dados numéricos a serem processados e analisados através de gráficos especificos.

Simplificações do método MCT foram desenvolvidas através de Métodos de Identificação Expedita ( NOGAMI \& COZZOLINO 1985; FORTES 1990; FORTES \& NOGAMI 1991; NOGAMI \& VILLIBOR 1994). Essas simplificações baseiam-se em dados obtidos de pequenas pastilhas de amostras com $20 \mathrm{~mm}$ de diâmetro e $5 \mathrm{~mm}$ de espessura (fotografias 1 e 2).

O cálculo do parâmetro c' segundo o Método Expedito - $4^{\text {a. }}$ Aproximação (NOGAMI \& VILLIBOR 1994) é baseado no uso das equações:

$$
\begin{array}{ll}
\text { contração } 0.1<\mathrm{ct}<0.5 & \mathrm{c}^{\prime}=\left(\log _{10} \mathrm{ct}+1\right) / 0.904 \\
\text { contração } \mathrm{ct}>0.6 & \mathrm{c}^{\prime}=\left(\log _{10} \mathrm{ct}+0.7\right) / 0.5
\end{array}
$$

A determinação do grupo MCT pelo Método Expedito é feita segundo os parâmetros c'e 


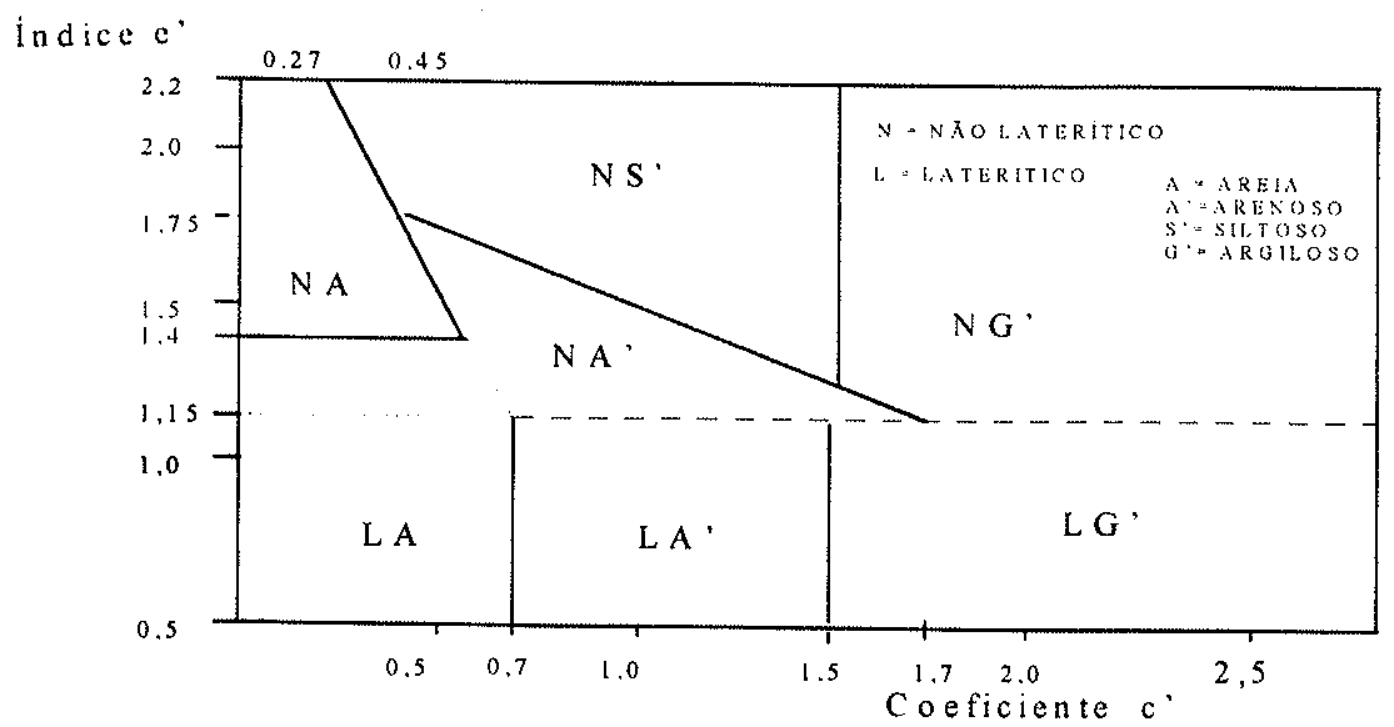

\begin{tabular}{|c|c|c|c|c|}
\hline (1) & $\begin{array}{l}\text { MINI-CBR (\%) } \\
\text { sobrcc. padrão }\end{array}$ & $\begin{array}{l}\text { EXPANSÃO }(\%) \\
\text { CONTRAÇÃO }(\%)\end{array}$ & $\begin{array}{l}\text { COEF. SORCÃO } \\
\log \left(\mathrm{cm} / V_{\min }\right)(\mathrm{s})\end{array}$ & $\begin{array}{l}\text { COEF.PERMEAB. } \\
\text { LOG }(\mathrm{CM} / \mathrm{S})(\mathrm{K})\end{array}$ \\
\hline$B=$ Baixo (a) & $<4$ & $<0.5$ & $<(-2)$ & $<(-6)$ \\
\hline$M=$ Médio (a) & 4 a 12 & 0,5 a 3 & $(-2) a(-1)$ & $(-6) \mathrm{a}(-3)$ \\
\hline $\mathrm{E}=$ Elevado (a) & 12 a 30 & $>3$ & $>(-1)$ & $>(.3)$ \\
\hline $\mathrm{EE}=$ Muito Elevado (a) & $>30$ & & & \\
\hline
\end{tabular}

(1) Corpos de prova compactados na massa especifica aparente máxima próxima da energia normal

\begin{tabular}{|c|c|c|c|c|c|c|c|c|}
\hline \multicolumn{2}{|c|}{ COMPORTAMENTO } & \multicolumn{4}{|c|}{ NÃO LATERITICO } & \multicolumn{3}{|c|}{ LATERITICO } \\
\hline \multirow[t]{2}{*}{ Grupo } & $\mathrm{MCT}$ & $\mathrm{NA}$ & $\mathrm{NA}^{\prime}$ & $\mathrm{NS}^{\prime}$ & $\mathrm{NG}^{\prime}$ & $\mathrm{LA}$ & $\mathrm{LA}^{\prime}$ & $\mathrm{LG}^{\mathrm{c}}$ \\
\hline & \multicolumn{8}{|c|}{ Vide Significado de B. M. E e EE na tabela acima } \\
\hline \multirow{6}{*}{ Propricdades } & sem imersão & $\mathrm{M}, \mathrm{E}$ & $E$ & $M, E$ & $\mathrm{E}$ & $E$ & $\mathrm{E}, \mathrm{EE}$ & $E$ \\
\hline & com imersão & M.E & M.E & B. M & B & $\mathrm{E}$ & $\mathrm{E}$ & $\mathrm{E}$ \\
\hline & EXPANSÃO & $\mathrm{B}$ & $\mathrm{B}$ & $\mathrm{E}$ & M.E & $\mathrm{B}$ & $B$ & B \\
\hline & CONTRAČ̃̃O & $\mathrm{B}$ & B.M & $\mathrm{M}$ & M.E & $\mathrm{B}$ & $B, M$ & $\bar{M}, \mathrm{E}$ \\
\hline & COEF. PERMEABILID. (k) & M.E & $B$ & B.M & B.M & B. M & $B$ & $\mathrm{~B}$ \\
\hline & COEF. SORCÃO (a) & $E$ & B.M & $E$ & M.E & $\mathrm{B}$ & $\mathrm{B}$ & $\mathrm{B}$ \\
\hline \multirow{6}{*}{$\begin{array}{l}\text { Utilização } \\
\text { (ordem de } \\
\text { preferência. } \\
\mathrm{nr}=\text { não reco- } \\
\text { mendado) }\end{array}$} & BASE DE PAVIMENTO & $\mathrm{nr}$ & $4^{\circ}$ & $\mathrm{nr}$ & $\mathrm{nr}$ & $2^{\circ}$ & $1^{9}$ & $3^{n}$ \\
\hline & REFORÇO DO SUBLEITO & $4^{\circ}$ & $5^{0}$ & $\mathrm{nr}$ & $\mathrm{nr}$ & $2^{0}$ & $1^{0}$ & $3^{2}$ \\
\hline & SUBLEITO COMPACTADO & $4^{\circ}$ & $5^{0}$ & $7^{\circ}$ & $6^{3}$ & $2^{\circ}$ & $1^{\circ}$ & $3^{\circ}$ \\
\hline & ATERRO (CORPO) COMPAC & $4^{0}$ & $5^{\circ}$ & $6^{9}$ & $7^{0}$ & $2^{\circ}$ & $1^{0}$ & $3^{0}$ \\
\hline & PROTECĂO Ä EROSĂO & $\mathrm{nr}$ & $3^{\circ}$ & $\mathrm{nr}$ & $\mathrm{nr}$ & $\mathrm{nr}$ & $2^{\circ}$ & $1^{0}$ \\
\hline & REVESTIMENTO PRIMÁRIO & $5^{\circ}$ & $3^{\mathrm{g}}$ & $\mathrm{nr}$ & $\mathrm{nr}$ & $4^{\circ}$ & $1^{\circ}$ & $2^{\circ}$ \\
\hline
\end{tabular}

\begin{tabular}{|c|c|c|c|c|c|c|c|c|}
\hline $\begin{array}{l}\text { Grupos tradicionais } \\
\text { obtidos de amostras } \\
\text { classificadas nos grupos }\end{array}$ & USCS & $\begin{array}{l}\text { SP } \\
\text { SM }\end{array}$ & $\begin{array}{c}\mathrm{SM} \\
\mathrm{SC}, \mathrm{ML}\end{array}$ & $\begin{array}{l}\text { SM.CL } \\
\text { ML. } \\
\mathrm{MH}\end{array}$ & $\begin{array}{l}\mathrm{MH} \\
\mathrm{CH}\end{array}$ & $\begin{array}{l}\mathrm{SP} \\
\mathrm{SC}\end{array}$ & $\mathrm{SC}$ & $\begin{array}{l}\mathrm{MH} \\
\mathrm{ML} \\
\mathrm{CH}\end{array}$ \\
\hline $\begin{array}{l}\text { MCT discriminados na } \\
\text { tabela acima }\end{array}$ & AASHO & A-2 & $\begin{array}{l}\text { A-2 } \\
A-4 \\
A-7\end{array}$ & $\begin{array}{l}\text { A-4 } \\
\text { A-5 } \\
\text { A-7 }\end{array}$ & $\begin{array}{l}A-6 \\
A-7-5 \\
A-7-6\end{array}$ & $A-2$ & $\begin{array}{l}A-2 \\
A-4\end{array}$ & $\begin{array}{c}A-6 \\
A-7-5\end{array}$ \\
\hline
\end{tabular}

Figura 3- Gráfico da Classificaçào MCT com Propriedades e Usos dos Grupos em Obras.

( NOGAMI \& VILLIBOR 1994, redesenhado) 


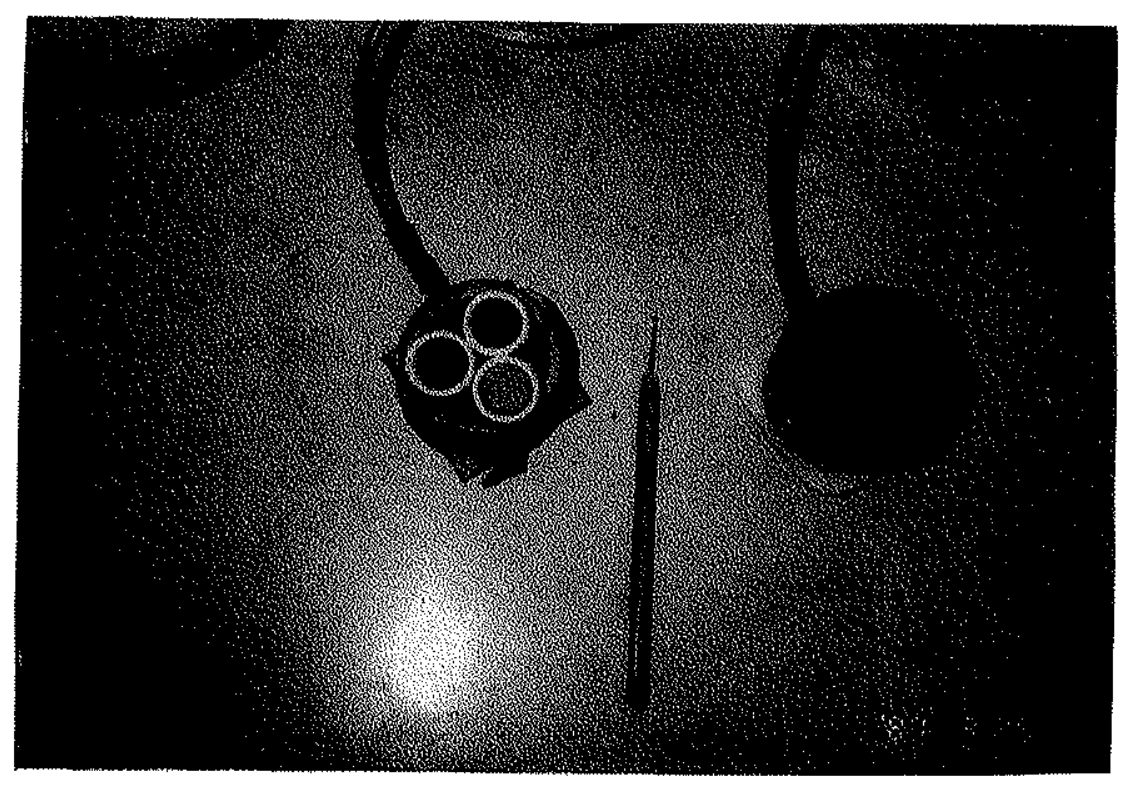

Fotografia 1 - Classificação geotécnica MCT, método expedito.

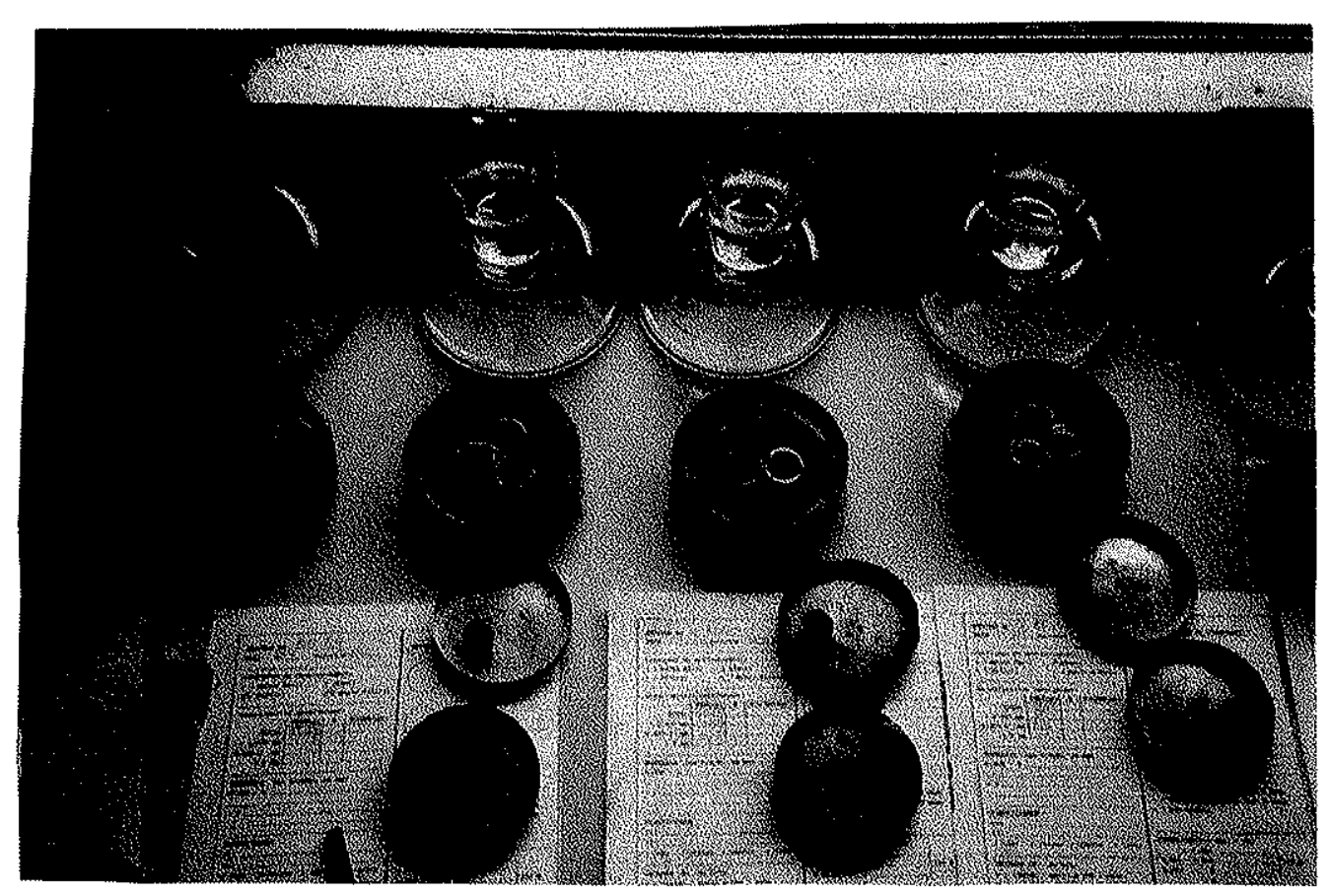

Fotografia 2 - Classificaçăo geotécnica MCT, método expedito. Laboratório de Tecnologia da Pavimentação, Escola Politécnica, USP. 
Penetração (Figura 3).A classificação MCT identifica sete grupos de solos divididos em duas classes: os de comportamento laterítico (LA, LA', LG'), e os de comportamento não lateríticos (NA, NA', NG', NS') (Figura 3).

Os solos de comportamento laterítico, quando devidamente compactados, apresentam baixa expansibilidade, pequena perda de resistência quando imersos em água, e aumento de resistência quando secos.

Devido a essas propriedades, os solos lateríticos são recomendados para serem utilizados em diversos tipos de obras viárias, tais como: aterro compactado, base de pavimento, reforço do subleito, proteção à erosão (exceto solos LA), e revestimento primário (principalmente solos LA'e LG') (NOGAMI \& VILLIBOR 1994).

Já os solos de comportamento não laterítico apresentam expansibilidade baixa (NA, NA') a elevada (NS', $N G^{\prime}$ ), e coeficiente de permeabilidade variando de baixo (NG') a elevado (NA, NA'). Quando secos, esses solos possuem predominantemente alta resistência, que decresce sensivelmente quando submersos em água, como no caso dos solos do grupo NG'e NS'.

Por apresentarem essas características, os solos de comportamento não laterítico, em geral, não detêm qualificações necessárias para uso em obras viárias. Por exemplo, solos do tipo NA, NS'e NG' não são recomendáveis para serem utilizados como base de pavimento ou proteção à erosão. Deve-se ainda evitar o emprego dos solos do grupo NS' e NG' como revestimento primário ou reforço do subleito (NOGAMI \& VILLIBOR 1994).

No presente trabalho foram analisadas neste trabalho 40 amostras, coletadas em diferentes camadas, assim distribuidas: 22 amostras em colúvio; 3 em sedimentos aluviais; 9 em sedimentos terciários da Bacia de São Paulo, e 6 em solo saprolitico de rochas do embasamento. Os ensaios foram efetuados no Laboratório de Tecnologia dos Transportes da Escola Politécnica da USP, sob orientação do Prof. Job Nogami, da Profa, Liedi B. Bernucci, e do geólogo Helder de Godoy, pósgraduando do Instituto de Geociências da USP.

Foi utilizado neste trabalho o Método Expedito - $4^{\mathrm{a}}$ aproximação, sendo os procedimentos adotados descritos em NOGAMI \& VILLIBOR (1994). 


\subsection{PALINOLOGIA}

No presente estudo foram realizadas análises palinológicas de sedimentos aluviais quaternários e sedimentos terciários da Bacia de São Paulo. Os sedimentos quaternários amostrados são constituídos por argilas orgânicas a turfa, cinza escura a cinza esverdeado, de planícies. Foram coletadas 12 amostras, sendo 3 com amostragem contínua, conforme indicado na Tabela 1.

\begin{tabular}{|c|c|c|c|}
\hline AMOSTRA & SEDIMENTO & LOCALIZAÇÃO & AMOSTRAGEM \\
\hline $\mathrm{H}-\mathrm{Al}-1$ & argila orgânica & $\begin{array}{l}\text { Av. Brig. Faria Lima (Zona } \\
\text { oeste) }\end{array}$ & Pontual * \\
\hline $\mathrm{H}-\mathrm{Al}-2$ & $\begin{array}{l}\text { argila orgânica com grânulos de } \\
\text { quartzo }\end{array}$ & $\begin{array}{l}\begin{array}{l}\text { R. Waldemar Ferreira (Zona } \\
\text { oeste) }\end{array} \\
\end{array}$ & Pontual * \\
\hline H-MS & $\begin{array}{l}\text { areia média argilosa na base, } \\
\text { passando a argila arenosa no topo }\end{array}$ & Córrego Morro do "S" (Zona sul) & Continua $(81 \mathrm{~cm})^{*}$ \\
\hline PCB & argila arenosa orgânica & Estádio do Pacaembu (Centro) & Pontual * \\
\hline $\mathrm{H}-\mathrm{PCB}$ & $\begin{array}{l}\text { argila a turfa na base passando a } \\
\text { areia no topo }\end{array}$ & Estádio do Pacaembu (Centro) & Continua $(90 \mathrm{~cm})^{*}$ \\
\hline $\mathrm{H}-\mathrm{Al}-11$ & argila orgânica & Córrego Verde (Zona oeste) & Pontual * \\
\hline $\mathrm{H}-\mathrm{Al}-13$ & argila orgânica & Córrego Verde (Zona oeste) & Pontual * \\
\hline ORAT & argila orgânica & $\begin{array}{l}\text { Córrego Oratório Pequeno (Zona } \\
\text { leste) }\end{array}$ & Contínua $(18 \mathrm{~cm})^{*}$ \\
\hline $\mathrm{H}-\mathrm{Al}-18$ & argila orgânica a turfa & $\begin{array}{l}\begin{array}{l}\text { Córrego Jacu-Pêssego (Zona } \\
\text { Leste) }\end{array} \\
\end{array}$ & Pontual \\
\hline H-Al- 19 & argila orgânica a turfa & Lapa (Zona Oeste) & Pontual* \\
\hline H-Al-20 & argila orgânica & Vila Formosa (Zona Leste) & Pontual \\
\hline $\mathrm{H}-\mathrm{Al}-23$ & argila orgânica & Córrego Franquinho (Zona Leste) & Pontual \\
\hline H-Al-24 & argila orgânica & Barra Funda (Zona Oeste) & Pontual * \\
\hline $\mathrm{H}-\mathrm{Tr}-1$ & argila orgânica & Jardins ( Centro ) & Trado- Pontual \\
\hline $\mathrm{H}-\mathrm{CO}-\mathrm{I}$ & colúvio argiloso & Jd. Paranapanema (Zona Sul) & \begin{tabular}{|l|} 
Pontual \\
Carvão) \\
\end{tabular} \\
\hline $\mathrm{H}-\mathrm{CO}-2$ & colúvio argiloso & Jd. Paranapanema (Zona Sul) & \begin{tabular}{|l|} 
Pontual \\
Carvão) \\
\end{tabular} \\
\hline $\mathrm{H}-\mathrm{CO}-6$ & colúvio & Capela do Socorro (Zona Sul) & $\begin{array}{l}\text { Pontual } \\
\text { Carvão) }\end{array}$ \\
\hline $\mathrm{H}-\mathrm{CO}-20$ & colúvio & S. Miguel (Zona Leste) & \begin{tabular}{|l|} 
Pontual \\
Carvão)
\end{tabular} \\
\hline
\end{tabular}

Tabela 1 - Locais de coleta de amostras para datação e análise palinológica $\left(^{*}\right)$ 
O estudo do material polínico dos sedimentos quaternários foi efetuado pelos Profs. JeanPierre Ybert, da ORSTOM ( em 1994 e 1995) e Paulo Eduardo de Oliveira, do Instituto de Geociências da USP (em 1996), e objetivaram gerar informações que subsidiassem a análise paleoclimática da área em estudo.

Foram analisadas ainda amostras de sedimentos da Formação Itaquaquecetuba, de provável idade neogênica (RICCOMINI 1989; ARAI \& YAMAMOTO 1995), coletadas em testemunhos de sondagem efetuada na Ráia Olímpica da Cidade Universitária, USP.

As amostras foram processadas nos laboratórios de palinologia do Departamento de Paleontologia e Estratigrafia da USP. Os sedimentos quaternários obtiveram tratamento padrão, segundo metodologia recomendada por YBERT et al. (1992), com adição de $2-4$ pílulas de esporos de Lycopodium clavatum (STOCKMARR 1971), para determinação da concentração de pólens (grãos de pólens por $\mathrm{cm}^{2}$ de sedimento úmido), esporos e outros palinomorfos. Já para os sedimentos da Formação Itaquaquecetuba as técnicas adotadas seguiram aquelas sugeridas por UESSUGUI (1979).

Os diagramas de porcentagem e concentração de pólens e esporos foram efetuados utilizando-se os programas TILIA e TILIAGRAPH.

\subsection{DATAÇ̃̃O RADIOCARBONO $\left({ }^{14} \mathrm{C}\right)$}

No presente estudo foram realizadas no 20 datações radiocarbono $\left({ }^{14} \mathrm{C}\right)$ com o objetivo de conhecer as idades dos depósitos quaternários estudados, estabelecendo a partir das análises palinológicas, correspondência entre as idades obtidas e as condições paleoclimáticas.

As análises ${ }^{14} \mathrm{C}$ foram realizadas pelo Laboratório Beta Analytic Inc., em Miami, Flórida, EUA.

As amostras encaminhadas para datação (Tabela 1), consistiam em sua maioria, de sedimentos argilosos orgânicos de planície aluvial além de fragmentos de carvão coletados na porção superior de camadas de colúvios.

A preparação das amostras consistiu na secagem a $30^{\circ} \mathrm{C}$, destorroamento e embalagem das mesmas, sendo efetuada nos laboratórios do Departamento de Paleontologia e Estratigrafia da USP. 


\subsection{DIFRATOMETRIA DE RAIOS X}

Foram realizados pelo Laboratório de Difratometria de Raios X do Departamento de Mineralogia e Petrografia da USP, análises de difratogramas de amostras totais e da fração argila de sedimentos terciários e quaternários, com intuito principal de identificação dos argilominerais presentes nos sedimentos.

Foi utilizado o difratômetro URD 6 fabricado pela Web Carl Zeiss Jena, com tubo de cobre alfa e gerador Irice.

A fração argila obteve tratamento específico como glicolagem (16h), e aquecimento $\left(550^{\circ}\right.$ $\mathrm{C}, 2 \mathrm{~h}$ ), objetivando melhor caracterização dos argilominerais presentes nas amostras. As amostras totais foram previamente homogeneizadas em moinho de ágata.

\subsection{MICROSCOPIA ELETRÔNICA DE VARREDURA}

As análises de MEV foram realizadas no Laboratório de Microscopia Eletrônica de Varredura do Instituto de Astronomia e Geofísica da USP, com objetivo de identificar e melhor caracterizar os argilominerais já determinados pelos difratogramas de Raios X.

As análises de MEV visaram ainda fornecer informações adicionais acerca de características importantes na definição dos ambientes deposicionais e processos diagenéticos atuantes na formação dos sedimentos estudados.

Foram obtidas imagens dos minerais presentes nas amostras, notadamente dos argilominerais, onde foi possivel observar seus arranjos internos, morfologia, tamanho e textura, além de dados qualitativos sobre sua composição química.

\subsection{ANÁLISE PETROGRÁFICA DE SEÇÕES DELGADAS}

A preparação de 9 lâminas delgadas foi efetuada pela Seção de Laminação do IG-USP, pelo método da impregnação, com resina plástica e corante Azul Oracet para ressaltar os espaços vazios dos sedimentos.

A análise petrográfica visou melhor caracterizar os colúvios presentes na área, principalmente quanto a sua mineralogia, granulometria, relação matriz /arcabouço e porosidade, 
aspectos estes considerados importantes na caracterização do comportamento geotécnico desses sedimentos.

\subsection{MAPA DE GRADIENTES HIDRÁULICOS}

Para melhor a compreensão dos movimentos tectônicos recentes (neotectônica) da região de estudos, optou-se pela confecção de mapa de gradientes hidráulicos, segundo o método desenvolvido por RODRIGUEZ (1993), aplicado em trabalhos posteriores ( e.g. SALVADOR 1994).

Para confeç̧ão do mapa foram utilizadas 20 cartas topográficas na escala 1:25.000 correspondentes as Levantamento Planialtimétrico efetuado pela Empresa Metropolitana de Planejamento da Grande São Paulo - EMPLASA, 1981.

Segundo a metodologia proposta por RODRIGUEZ (1993), calculou-se para cada drenagem de segunda ordem a razão da diferença de altitude entre a cabeceira e a foz dessas drenagens sobre a distância correspondente. Os 3422 valores obtidos, foram atribuídos ao ponto médio das drenagens, e coletadas suas coordenadas para a confecção do mapa de isovalores.

Os mapas apresentados foram executados através do programa SURFER for WINDOWS, versão 6.0, da GOLDEN SOFTWARE, pertencente ao Curso de Pós-Graduação em Geociências do Instituto de Geociências e Ciências Exatas da UNESP em Rio Claro.

O método de interpolação utilizado foi o Inverso do Quadrado da Distância definido segundo a equação apontada a seguir:

$$
\begin{aligned}
& \mathrm{Z}=\left(\sum \mathrm{Zi} / \mathrm{h}^{2}{ }_{\mathrm{ij}}\right) /\left(\sum \mathrm{l} / \mathrm{h}^{2}{ }_{\mathrm{ij}}\right), \\
& \text { onde } \mathrm{Z}=\text { valor a ser interpolado } \\
& \mathrm{Zi}=\text { valores vizinhos } \\
& \mathrm{h}_{\mathrm{ij}}=\text { distâcia entre o nó da malha e o dado }
\end{aligned}
$$




\section{CAPÍtulo 4}

\section{CONTEXTO GEOMORFOLÓgICO E GEOLÓGICO DA BACIA DE SÃO PAULO}

\subsection{ASPECTOS GEOMORFOLÓGICOS}

O relevo do Estado de São Paulo tem sido estudado por diversos autores. Do ponto de vista de sua classificação têm sido reconhecidos compartimentos geomorfológicos distintos, desde a primeira subdivisão efetuada por MORAES REGO (1932), como as grandes unidades do Planalto Ocidental e a Depressão Periférica (IPT 1981). Devem-se mencionar ainda a classificação de DEFFONTAINES (1935), que efetuou a divisão geomorfológica do Estado distinguindo o Litoral, o Alto da Serra, o Vale Médio do Paraíba, a região de Campos do Jordão, a Mantiqueira, as Serras Graníticas do Norte, a Zona Cristalina, a Volta de São Paulo, a Depressão Periférica, e a Zona dos Arenitos do Centro e Oeste do Estado.

MONBEIG (1949) apresenta a proposta da divisão regional do Estado elaborada pela Secção Regional de São Paulo da Associação dos Geógrafos Brasileiros, mantendo as principais divisões propostas pelos dois autores citados anteriormente, quais sejam: o Litoral, a Depressão Periférica e o Planalto Central, definindo ainda o Planalto Atlântico onde são incluídas as "terras altas Atlânticas do Estado".

Posteriormente, ALMEIDA (1964) revisou a divisão geomorfológica do Estado, definindo cinco Províncias divididas em Zonas e Sub-zonas (Figura 4). Segundo a proposta do autor, a Bacia de São Paulo estaria contida na Zona denominada de Planalto Paulistano, termo esse definido pelo mesmo autor em 1958 ( ALMEIDA 1958).

A classificação de ALMEIDA (1964) é baseada em aspectos topográficos, estruturais e genéticos, uma vez que o autor considera a morfologia estrutural como fator definidor das grandes formas topográficas do Estado. Esse trabalho foi adotado como referência na elaboração da Carta Geomorfológica do Estado de São Paulo pelo Instituto de Pesquisas Tecnológicas (IPT 1981).

O Planalto Paulistano apresenta assim, cerca de $5.000 \mathrm{~km}^{2}$, com altitudes variando entre 715 e $900 \mathrm{~m}$, exibindo relevo suavizado, com espigões e morros com altura modesta. Os limites norte e sul desta feição geomorfológica são marcados respectivamente pelas Serras da Cantareira/ Serraria de São Roque e Serras do Mar/ Paranapiacaba (Figura 5). A oeste confina com o Planalto de Ibiúna e a leste estende-se até o Planalto de Paraitinga e Médio Vale do Paraíba. 


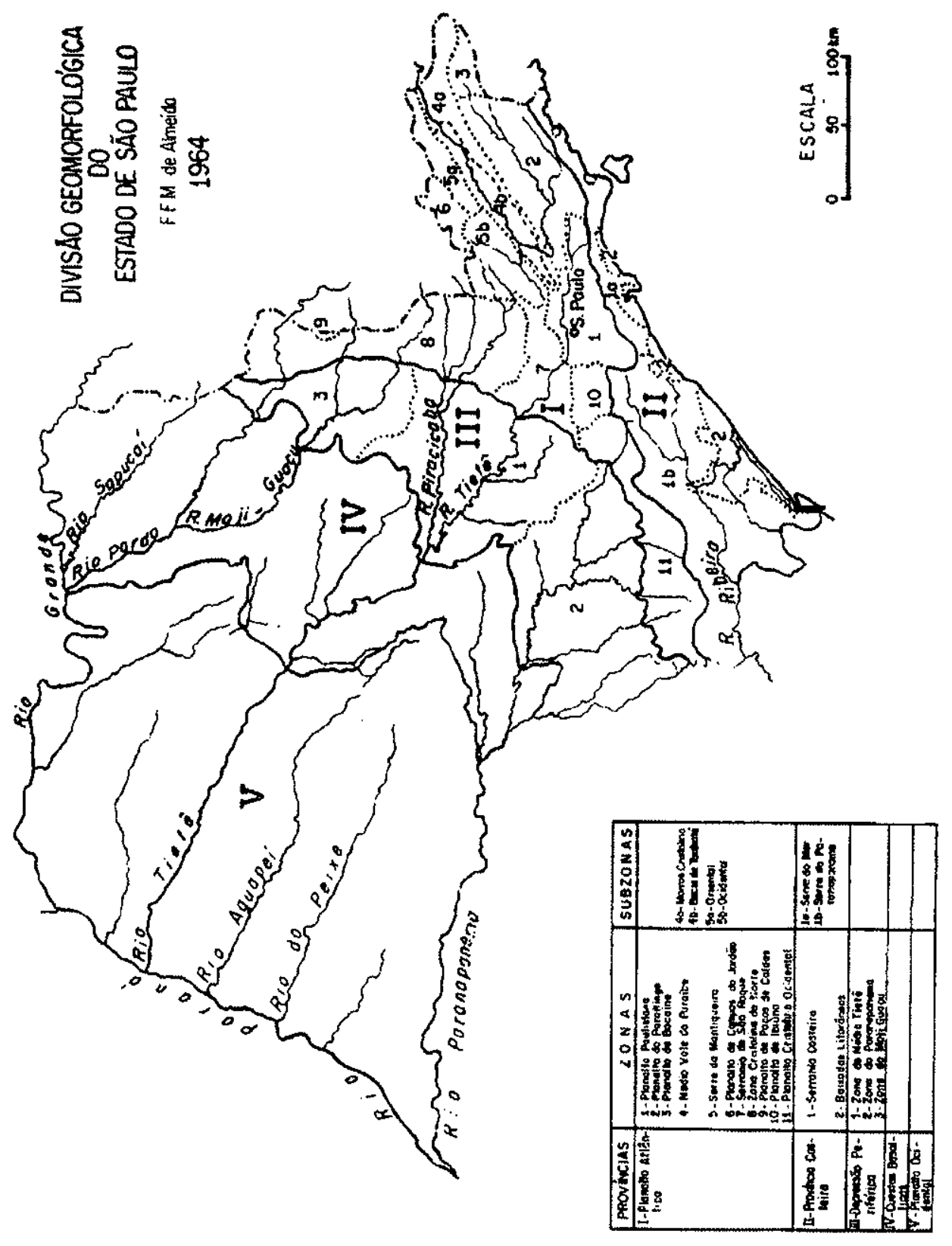

Figura 4. Divisão geomorfológica do Estado de São Paulo segundo ALMEIDA (1964) 


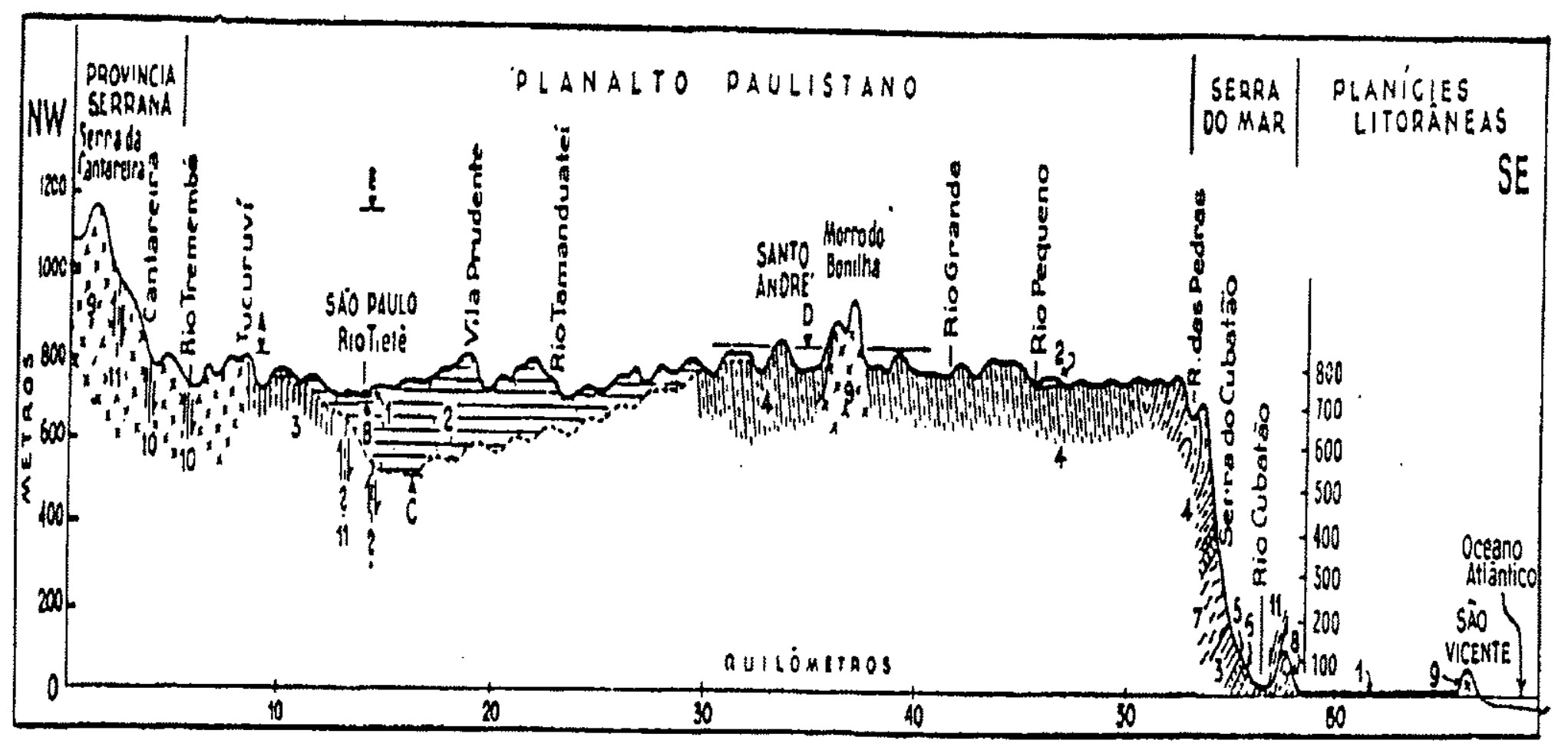

Figura 5. Seção morfológico-estrutural da Serra da Cantareira ao oceano, através do Planalto Paulistano e da Serra do Mar. 1-depósitos quaternários das várzeas; 2-camadas de São Paulo; 3-filitos; 4-micaxistos (e gnaisses micáceos); 5-quartzitos; 6-calcáreos; 7-biotita-gnaisses (de origem migmático); 8-migmatitos facoidais; 9 granitos; 10-falhas provadas; 11-falhas prováveis; A-nível máximo atingido pelas camadas de São Paulo; B-nível de soleira de Barueri (710m); C-máxima profundidade conhecida, da Bacia de São Paulo (543m); D-nível médio da superficie de erosão do Alto Tietê ( 825 a 850m); E-nível da paneplanície do Japi.(ALMEIDA 1958) 
Segundo a proposta do IPT (1981) o Planalto Paulistano é ainda dividido em duas SubZonas: Morraria do Embu e Colinas de São Paulo. Essa última domina a porção centro-norte da unidade, desenvolvendo-se principalmente em área de ocorrência da Bacia de São Paulo.

ALMEIDA (1964) relaciona a origem do relevo do Planalto Paulistano à destruição da Superfície Japi, considerada de idade paleogênica (ALMEIDA 1958), e a instalação da Superfície do Alto Tietê, esta de idade polêmica segundo esse autor, que a considera como mais jovem que a Superfície Japi.

A superfície de erosão do Alto Tietê é verificada notadamente em áreas de rochas mais tenras do Planalto Paulistano com altitudes variando entre 800 e $850 \mathrm{~m}$, adentrando serras a NW da capital (ALMEIDA 1958). O autor citado apresenta perfis situados na zona norte de São Paulo, evidenciando a presença dessa superficie (Figura 6), desenvolvida anteriormente a "sedimentação das camadas São Paulo, admitida como pliocênica" (ALMEIDA 1958, 1964).

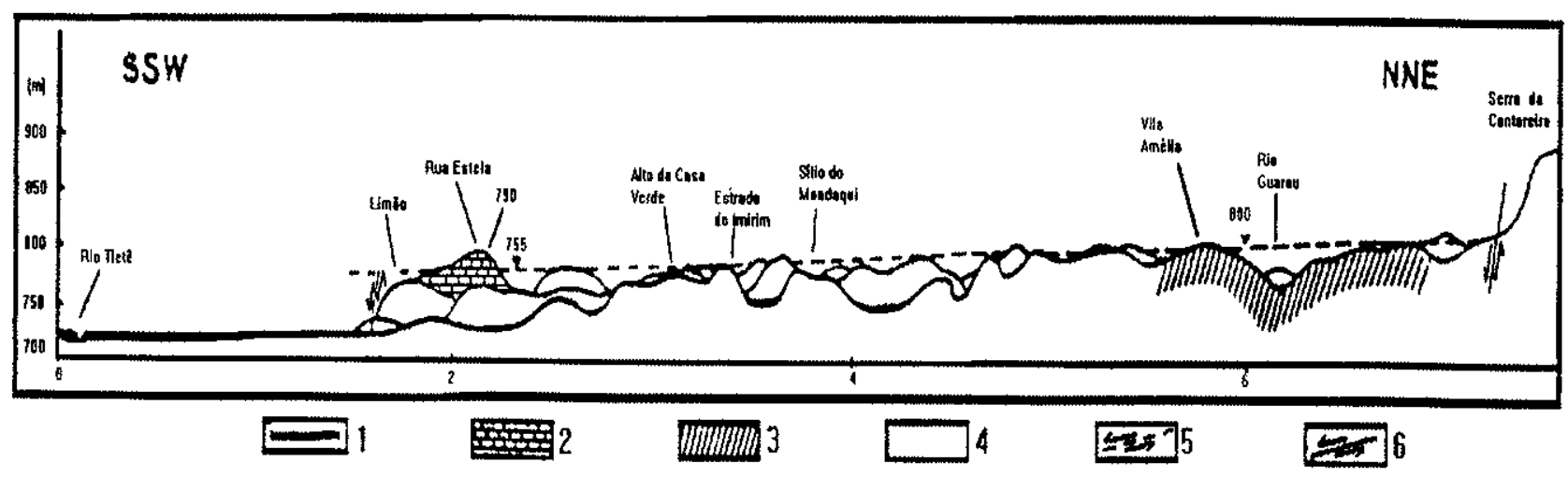

Figura 6. Três perfis, paralelamente projetados, eqüidistantes de $500 \mathrm{~m}$, traçado através do divisor de águas entre o Rio Cabuçu de baixo e o Córrego Mandaqui. Evidenciam a extensão da superfície de erosão do alto Tietê às faldas da serra da Cantareira e sua inclinação para o interior da Bacia. Observe-se como testemunhos das camadas terciárias do Bairro do Limão se sobrepõem ao nivel daquela superficie (ALMEIDA 1958).

Entretanto, AB'SABER (1957) supõe a existência de um peneplano intermediário com altitudes variando entre 900 e $950 \mathrm{~m}$, que sofreu rápida erosão e entalhamento vertical. A deposição das "camadas São Paulo" se deu posteriomente a esse evento. 
Segundo AB'SABER (1957) as regiões serranas do Planalto Atlântico não apresentam características propícias para o desenvolvimento de aglomerações urbanas. Entretanto, podem ser reconhecidos no planalto compartimentos locais, dentre eles as denominadas "bacias sedimentares de formação recente, de origem flúvio-lacustre" sobre as quais desenvolveram-se metrópoles como Curitiba e São Paulo, esta última considerada como exemplo típico de cidade de planalto (AZEVEDO 1958).

Os trabalhos desenvolvidos na década de 50 (e.g. AB'SABER 1957, AZEVEDO 1958) mostram que os limites do sitio urbano de São Paulo não ultrapassavam as colinas, terraços fluviais e áreas de planície de inundação situadas próximas da confluência dos rios Tietê e Pinheiros. Atualmente verifica-se que a cidade ultrapassou esses limites da Bacia de São Paulo, adentrando morros e morrotes sustentados por rochas do embasamento pré-cambriano (ABREU 1992).

AB'SABER (1957) reconhece oito elementos topográficos da área de desenvolvimento do sítio urbano, à época, sendo representados por: “altas colinas de topo aplainado do Espigão Central com altitudes variando entre $805-830 \mathrm{~m}$; altas colinas dos rebordos dos espigões principais (780$830 \mathrm{~m}$ ); patamares e rampas suaves e escalonados dos flancos do espigão central $(750-800 \mathrm{~m})$; colinas suaves do nível intermediário $(745-750 \mathrm{~m})$; baixas colinas terraceadas $(730-734 \mathrm{~m})$; terraços fluviais de baixadas relativamente enxutas (724-730 m); planícies de inundação sujeitas a inundações periódicas (722-724 m); planícies de inundação sujeitas a inundações anuais (718-722 $\mathrm{m})$.

A maioria dessas feições verificadas pelo autor pode ser ainda observada no relevo intensamente modificado da metrópole paulistana, à exceção das planícies de inundação, atualmente aterradas, com canais retificados, conforme pode ser observado nas várzeas dos principais rios e córregos que drenam o Município de São Paulo: Tietê, Pinheiros, Tamanduateí, Aricanduva e Cabuçu.

Essas drenagens apresentavam outrora padrão meandrante bem definido, com planície de inundação bem desenvolvida, e freqüente ocorrência de feições de abandono de canal (meandros abandonados), conforme pode ser observado em mapas e fotografias aéreas mais antigas (e.g. PMSP 1930, AB’SABER 1957). 


\subsection{BACIA DE SÃO PAULO}

\subsubsection{ASPECTOS GERAIS}

Os sedimentos da Bacia de São Paulo distribuem-se por uma área aproximadamente ovalada com cerca de $1.000 \mathrm{~km}^{2}$. A norte, exibe borda retilínea, marcada pelo sistema de falhas Taxaquara - Jaguari. A sul, apresenta contatos irregulares com o embasamento pré-cambriano (Anexo A).

Seus eixos maior $(60 \mathrm{~km})$ e menor $(25 \mathrm{~km})$, dispõem-se respectivamente entre as localidades de Arujá e Interlagos, Santo André e Santana. São ainda observadas ramificações a sul, de Interlagos para Bororé e Cipó, e a leste, de Itaquaquecetuba para Mogi das Cruzes e Palmeiras.

A primeira referência aos sedimentos da Bacia de São Paulo foi efetuada por MAWE (1812) na região central da cidade. PISSIS (1842a) descreveu um perfil de $18 \mathrm{~m}$ de espessura, semelhante ao observado por MAWE (1812), apresentando em seguida (PISSIS 1842b), uma seção estratigráfica da bacia. Segundo RICCOMINI (1989), este trabalho (PISSIS 1842b) contém a primeira referência litoestratigráfica da Bacia de São Paulo.

Os sedimentos da bacia foram inicialmente denominados "argilas de São Paulo", por MORAES REGO (1930), passando posteriormente a "camadas de São Paulo" (MORAES REGO 1933), termo esse empregado em diversos trabalhos subseqüentes (e.g. MENDES 1950 e ALMEIDA 1955). Somente em 1962 (MEZZALIRA 1962), surge a referência Formação São Paulo.

Na década de 80 registram-se importantes avanços no nivel de conhecimento da bacia. Merecem destaque, dentre muitos, os seguintes trabalhos: COIMBRA et al. (1983), no qual é definida a Formação Itaquaquecetuba; de MELO et al. (1986), onde são relacionados os diferentes sistemas deposicionais além da apresentação de idades dos sedimentos através de análises palinológicas; RICCOMINI (1989), que pode ser considerado como um marco, pois propôs uma revisão da litoestratigrafia não só da Bacia de São Paulo, como das outras bacias que estariam preteritamente interligadas no denominado Rift Continental do Sudeste do Brasil.

Segundo a proposta de RICCOMINI (1989), adotada no presente trabalho, a Bacia de São Paulo seria constituida por depósitos sedimentares das seguintes unidades litoestratigráficas: 
Formação Resende, Formação Tremembé, Formação São Paulo, e Formação Itaquaquecetuba (Figura 7)
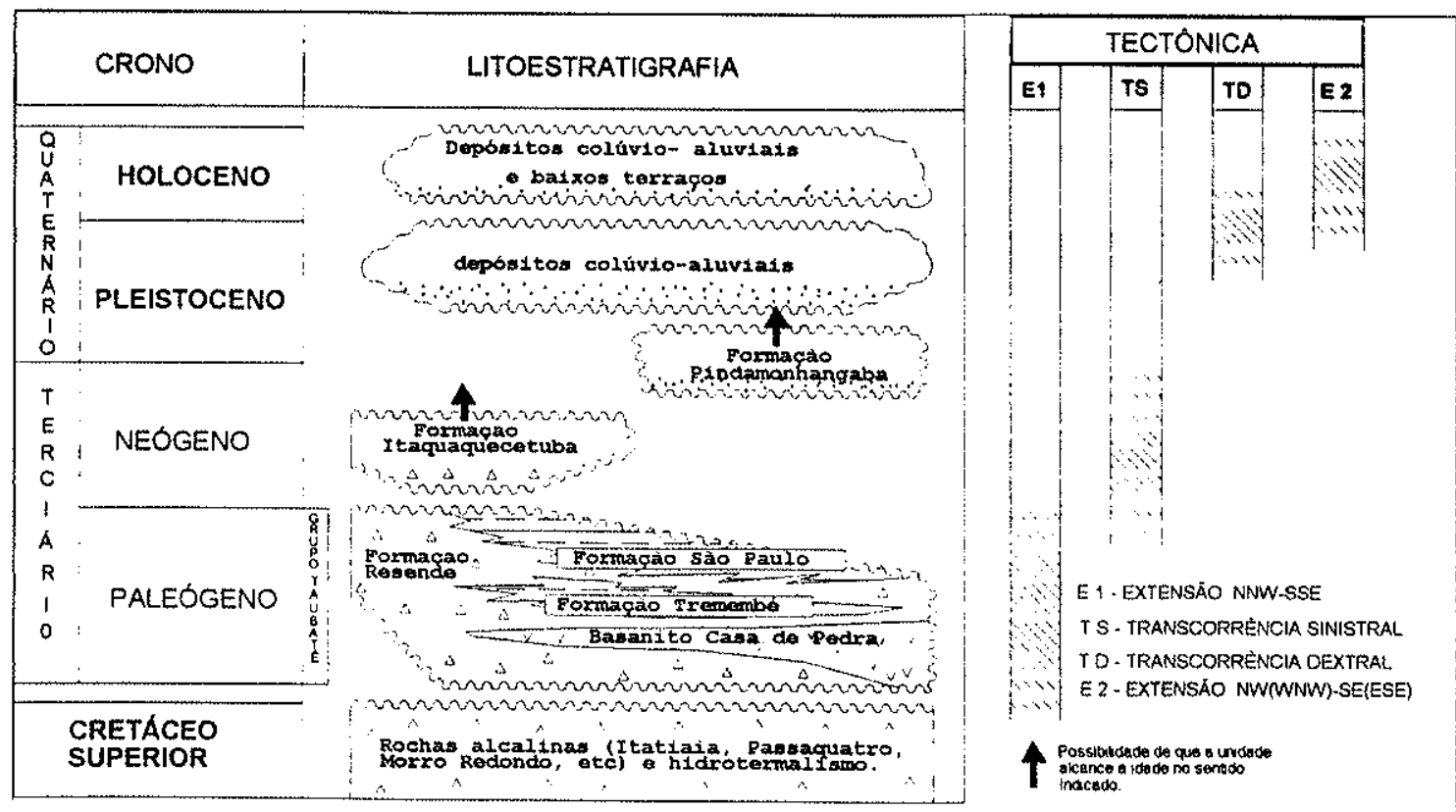

Figura 7. Relações entre a litoestratigrafia e a tectônica no "Rift" Continental do Sudeste do Brasil (RICCOMINI \& COIMBRA 1992, redesenhado por ROCHA 1995).

\subsubsection{FORMAÇÃO RESENDE}

A Formação Resende ( sensu RICCOMINI 1989) caracteriza-se pela presença de depósitos de sistema de leques aluviais, sendo possivel a sua subdivisão em fácies proximal, predominando conglomerados polimíticos, brechas e diamictitos e em fácies distal constituída por lamitos por vezes associados a arenitos e conglomerados de sistema fluvial entrelaçado.

A fácies proximal desta unidade é comumente verificada na,borda norte da bacia, tectonicamente ativa à época de deposição desse sedimentos, onde podem alcançar mais de $200 \mathrm{~m}$ de espessura.

A Formação Resende é a unidade de maior expressão em volume de sedimentos na bacia representando mais de $80 \%$ do seu preenchimento sedimentar ( RICCOMINI \& COIMBRA 1992). 
Os lamitos tem expressiva ocorrência dentro da unidade, principalmente em superfície. São caracterizados por apresentar matriz argilo-arenosa abundante, envolvendo, em sua maioria, grânulos a seixos de quartzo do arcabouço.

Os sedimentos da Formação Resende exibem contatos interdigitados com os depósitos das formações São Paulo e Tremembé (RICCOMINI 1989; TAKIYA 1991) denotando assim a coexistência de diversos sistemas deposicionais durante o preenchimento sedimentar da bacia.

Os depósitos da Formação Resende foram observados na presente pesquisa em diversos locais do município, notadamente nas zonas Sul e Leste, onde estão presentes em pequenas exposições. Correspondem na maioria das vezes a lamitos de coloração acinzentada, esverdeada e avermelhada, com manchas arredondadas a irregulares de constituição mais argilosa.

Essa unidade foi também descrita em duas sondagens, mista e a trado, com testemunhagem contínua, executadas respectivamente no Parque Piqueri, Zona Leste (Fotografias 3,4 e figura 8) e na área dos Jardins (Fotografia 5).

No Parque Piqueri a sondagem chegou a $15.8 \mathrm{~m}$ de profundidade, atravessando no intervalo de 2.2 a $6.0 \mathrm{~m}$ sedimentos aluviais quaternários predominantemente arenosos a conglomeráticos, com raras intercalações argilosas. Os sedimentos da Formação Resende foram observados a partir de $6.0 \mathrm{~m}$ de profundidade, sendo representados principalmente por lamitos arenosos a argilosos com típica coloração esverdeada a acinzentada, e intercalações conglomeráticas (Fotografia 3 ).

Na sondagem executada no Parque Piqueri a $7.5 \mathrm{~m}$ de profundidade notou-se a presença de areia conglomerática cinza amarelada a esbranquiçada, com grãos milimétricos angulosos a subangulosos endurecidos, comparáveis aos sedimentos

hidrotermalizados descritos por RICCOMINI et al. (1988) no Parque D. Pedro II, os quais apresentam aspecto de brecha, com fragmentos de tamanhos variados, até centimétrico, coloração verde acinzentada, verificados a partir de $6 \mathrm{~m}$ de profundidade.

Os autores citados apontam a presença de minerais como a dickita e barita, que evidenciariam, juntamente com outras características descritas, atividades hidrotermais. 
Fotografia 3 - Testemunhos de sondagem executada no Parque do Piqueri, SP.

Intervalo 2,43 a 12,08, apresentando sedimentos aluviais quaternários predominantemente arenosos e conglomeráticos até a profundidade de 6 metros, onde verifica-se contato discordante com sedimentos lamíticos arenosos e argilosos com granulometria fina a média da Formação Resende, a qual ocorre até o final do intervalo apresentado (12,08 metros).

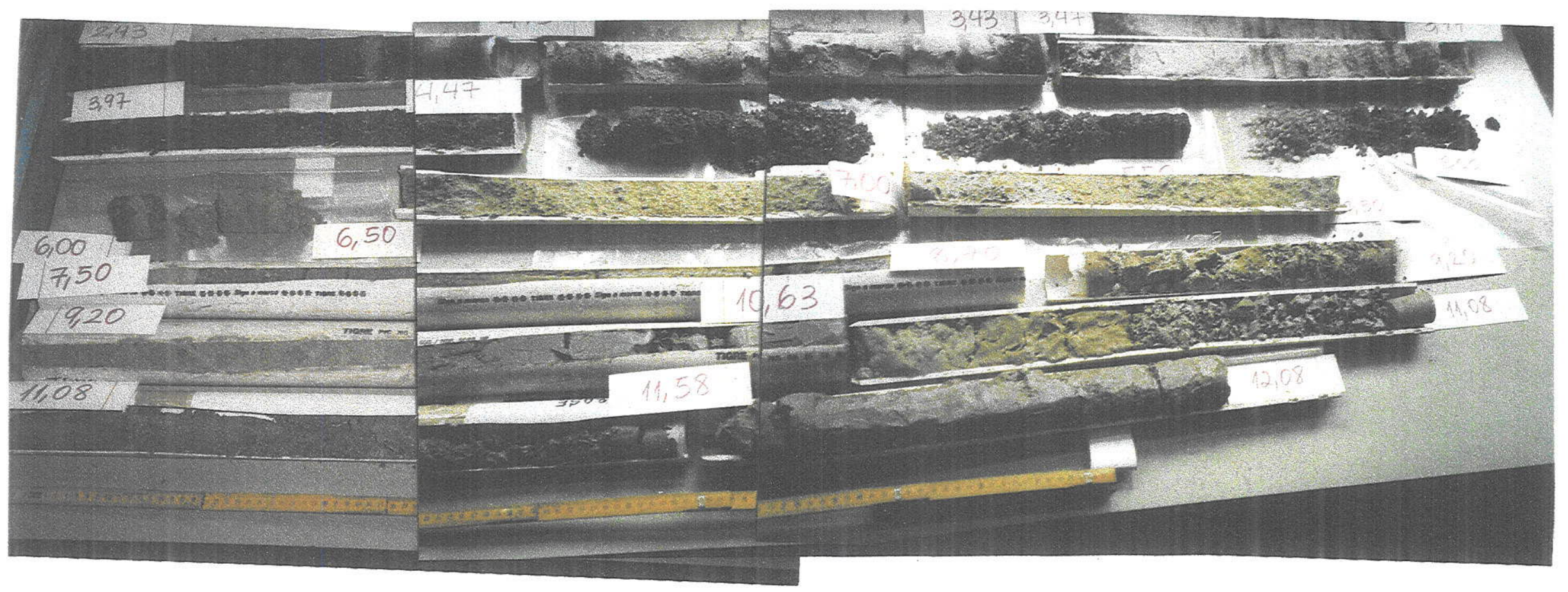




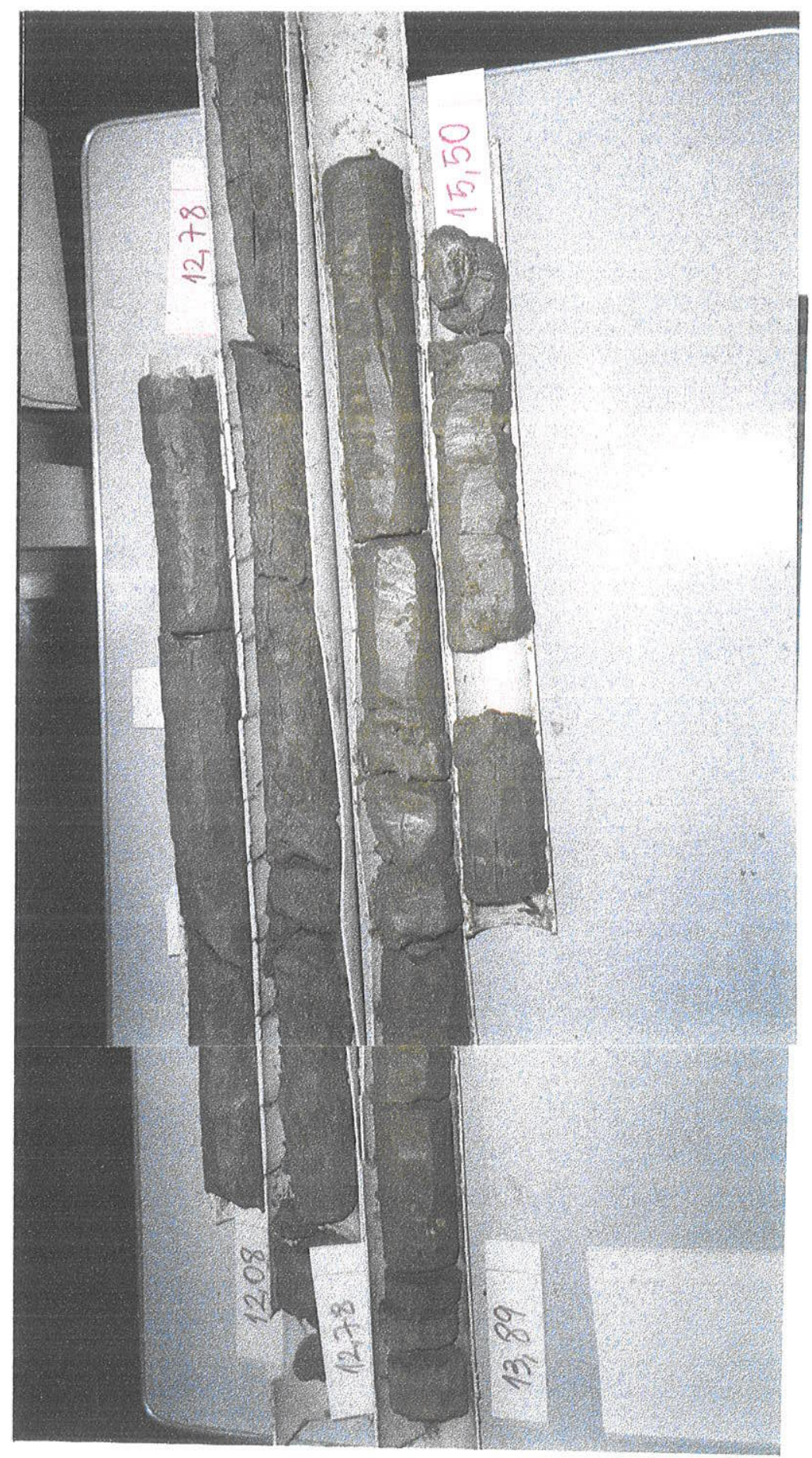

Fotografia 4 - Testemunhos de sondagem. Parque Piqueri, SP. Intervalo 12,08 a15,50 metros constituído por lamitos arenosos passando a lamito argiloso. 
Prof.

$(\mathrm{m})$

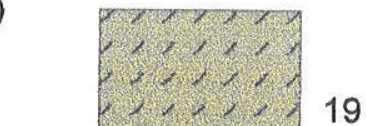
1 Lamito argiloso, compacto apresentando grãos milimétricos de quartzo e porções mais arenosas

1,0

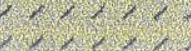

2,2

2,4

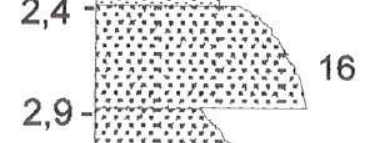

15

3,5
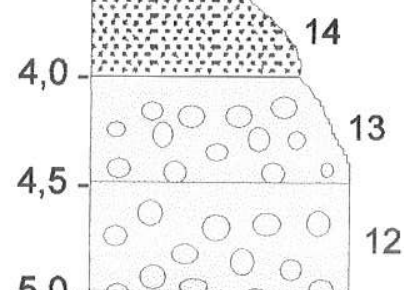

11
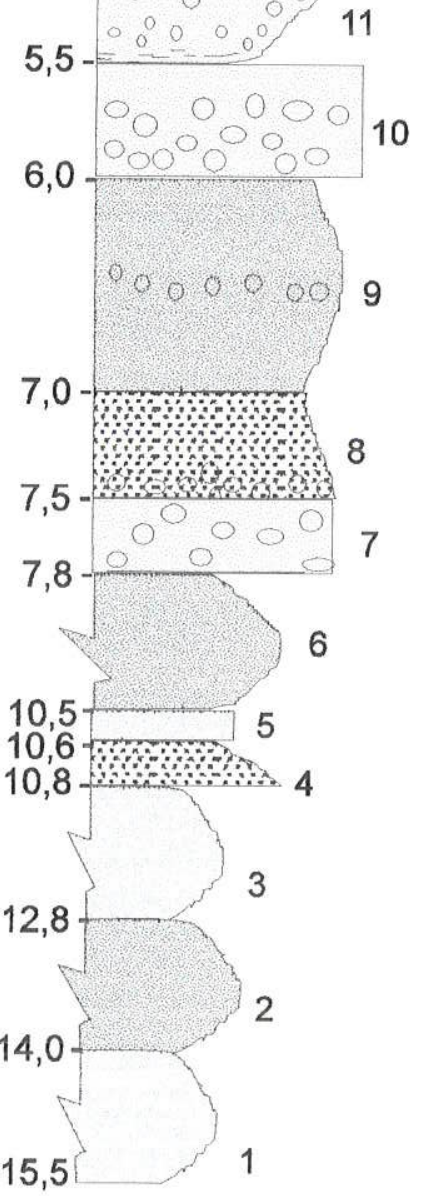

2 Lamito arenoso com manchas avermelhadas (cor de alteração)

( amostragem para MEV e RX a 12,8 m )

3 Lamito argiloso cinza esverdeado, duro

4 Areia média a fina esbranquiçada, com grãos angulosos, imatura, mal selecionada e facilmente desagregável

5 Sedimento argiloso esverdeado (amostragem para MEV e RX a 10,5 m )

6 Lamito arenoso, esverdeado,bastante resistente a penetração apresentando, de 8,6 a 8,7 m, intercalações de porções predominantemente argilosa

7 Areia conglomerática, esverdeada, endurecida, com grãos de até $0,4 \mathrm{~cm}$ predominantemente de quartzo e feldspato

8 Areia fina a média esverdeada passando a areia conglomerática

9 Lamito arenoso, maciço, esverdeado (Formação Resende), com grãos angulares de quartzo e matriz argilosa, com faixa conglomerática entre 6,5 a 6,6 m. Esse pacote apresenta-se em contato discordante com as camadas quaternárias sobrejacentes

10 Conglomerado esbranquiçado com pouca matriz arenosa e com seixos de quartzo subangulares chegando a $1 \mathrm{~cm}$ no intervalo de 5,5 a 5,7 metros

11 Conglomerado semelhante ao anterior com intercalações de argila orgânica preta na base do intervalo

12 Conglomerado com grãos de até $0,7 \mathrm{~cm}$ e matriz arenosa pouco abundante com porções mais argilosas

13 Conglomerado apresentando Intercalação de argila orgânica

14 Areia esbranquiçada média, pouco compacta com grãos subangulares a angulares de quartzo e estratificação plano paralela. Nota-se,próximo à base do intervalo, uma faixa conglomerática com grãos angulares variando de 1 a $4 \mathrm{~mm}$, predominantemente de quartzo e feldspato

15 Areia branca fina com grãos subangulares a subarredondados com intercalações, no topo e na base do intervalo, de lentes argilosas, de coloração marrom, e fragmentos de restos vegetais

16 Areia fina a média, micácea, inconsolidada, de coloração marrom e com pouca matriz argilosa

17 Argila orgânica, plástica, inconsolidada de coloração marrom

18 Solo areno-argiloso, marrom, com seixos $(<1 \mathrm{~cm})$ angulosos a subarredondados de quartzo e quartzitos

19 Solo orgânico, marrom escuro com fragmentos de folhas 


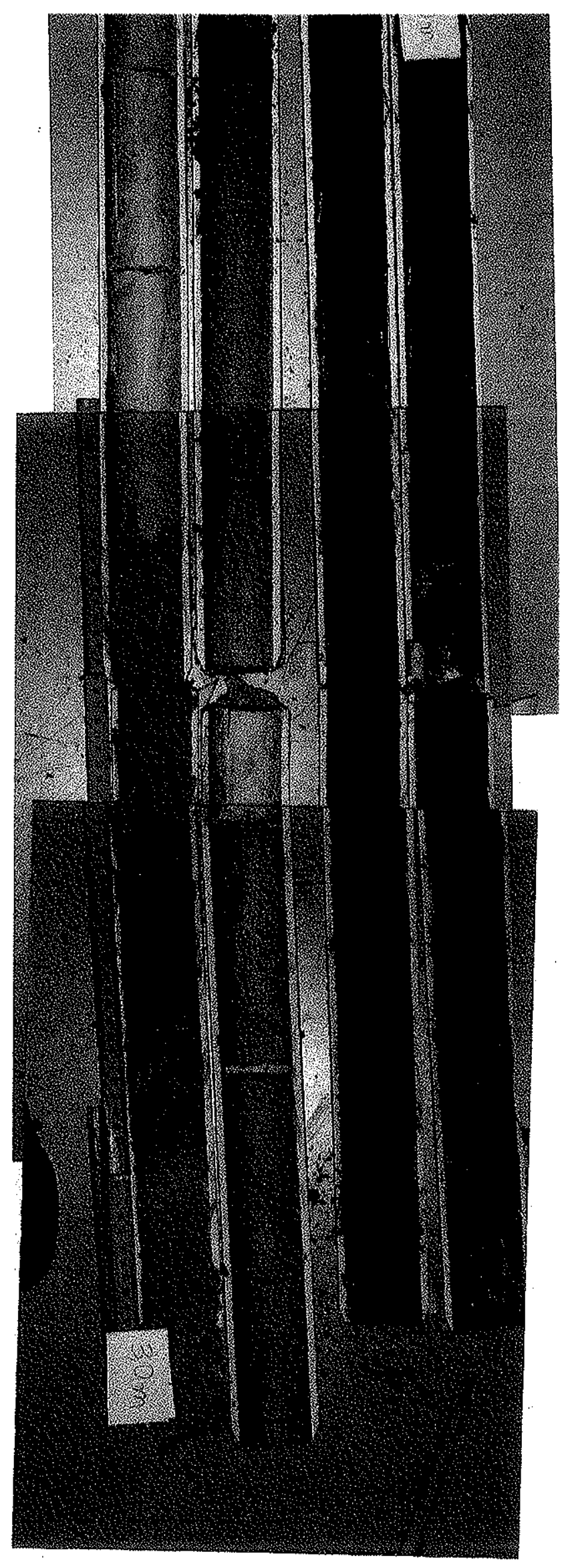

Fotografia 5. Testemunhos de sondagem executada à Rua Colômbia, SP, apresentando camada de aterro de 0,0 a 0,3 metros, argila orgânica de 0,3 a 1,0 metros e sedimentos da Formação Resende de 1,0 a 3,0 metros. $\hat{A}$ 0,6 metros foi efetuada datação ${ }^{14} \mathrm{C}$ que apontou idade $2110+/-60$ anos AP. 
Em lâmina petrográfica efetuada com amostras desses sedimentos endurecidos do Parque Piqueri (amostra PI- 7.5), notou-se a presença predominante de quartzo $(55 \%)$ e feldspato (microclíneo, 35\%), além de fragmentos líticos e muscovita (Fotografia 6). Verificou-se como minerais acessórios a titanita, o epidoto, e a turmalina (Fotografia 7). Os clastos são sustentados por matriz argilosa de coloração amarelada na qual constatou-se indícios de recristalização (Fotografia 8).

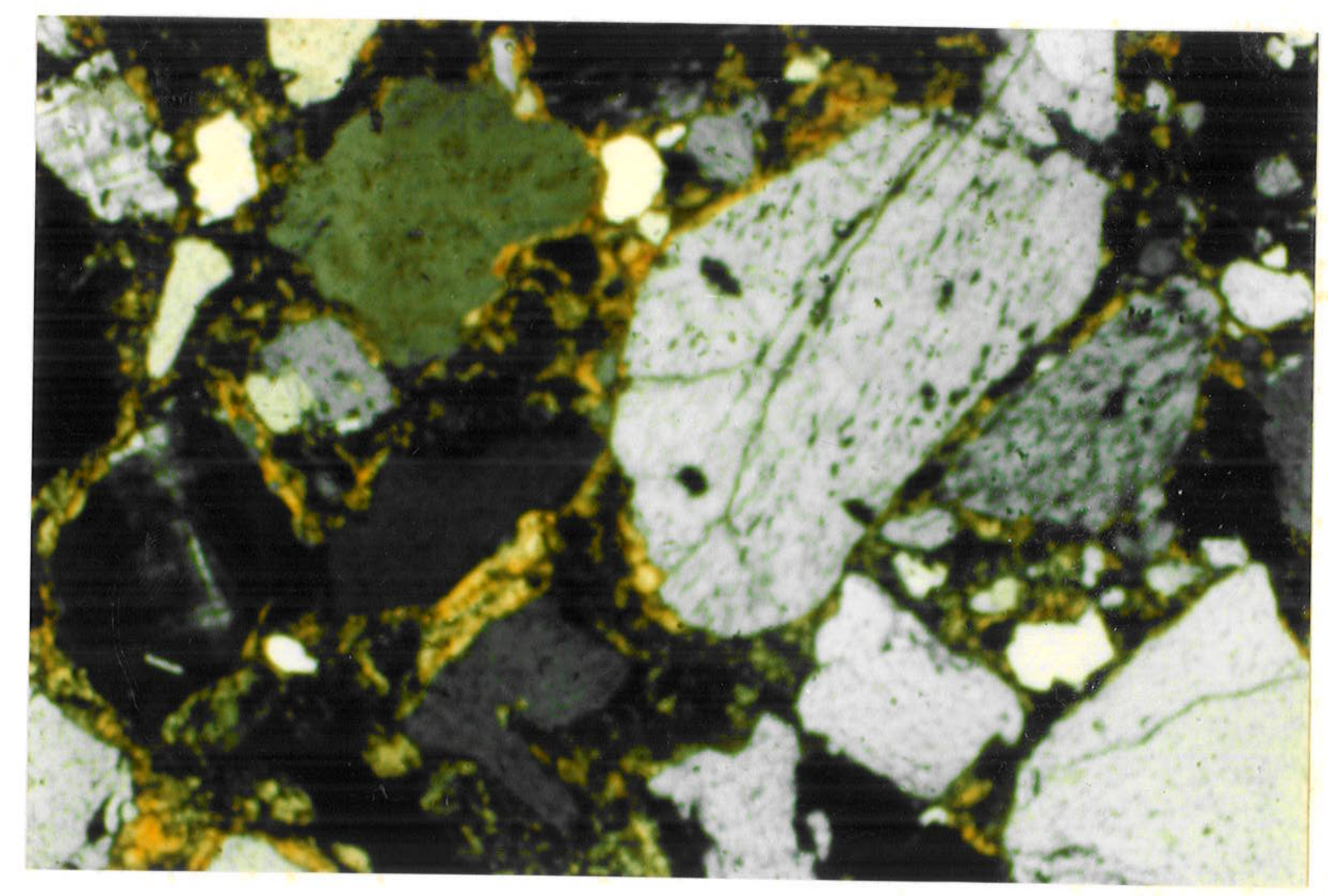

Fotografia 6. Areia conglomerática da Formação Resende apresentando grãos de quartzo ( no centro e no canto direito inferior) e microclínio ( canto esquerdo inferior ). Sondagem Parque Piqueri, 7,5 metros de profundidade, Zona Leste. Fotomicrografia. Nicóis cruzados.Aumento2, 5 X. 


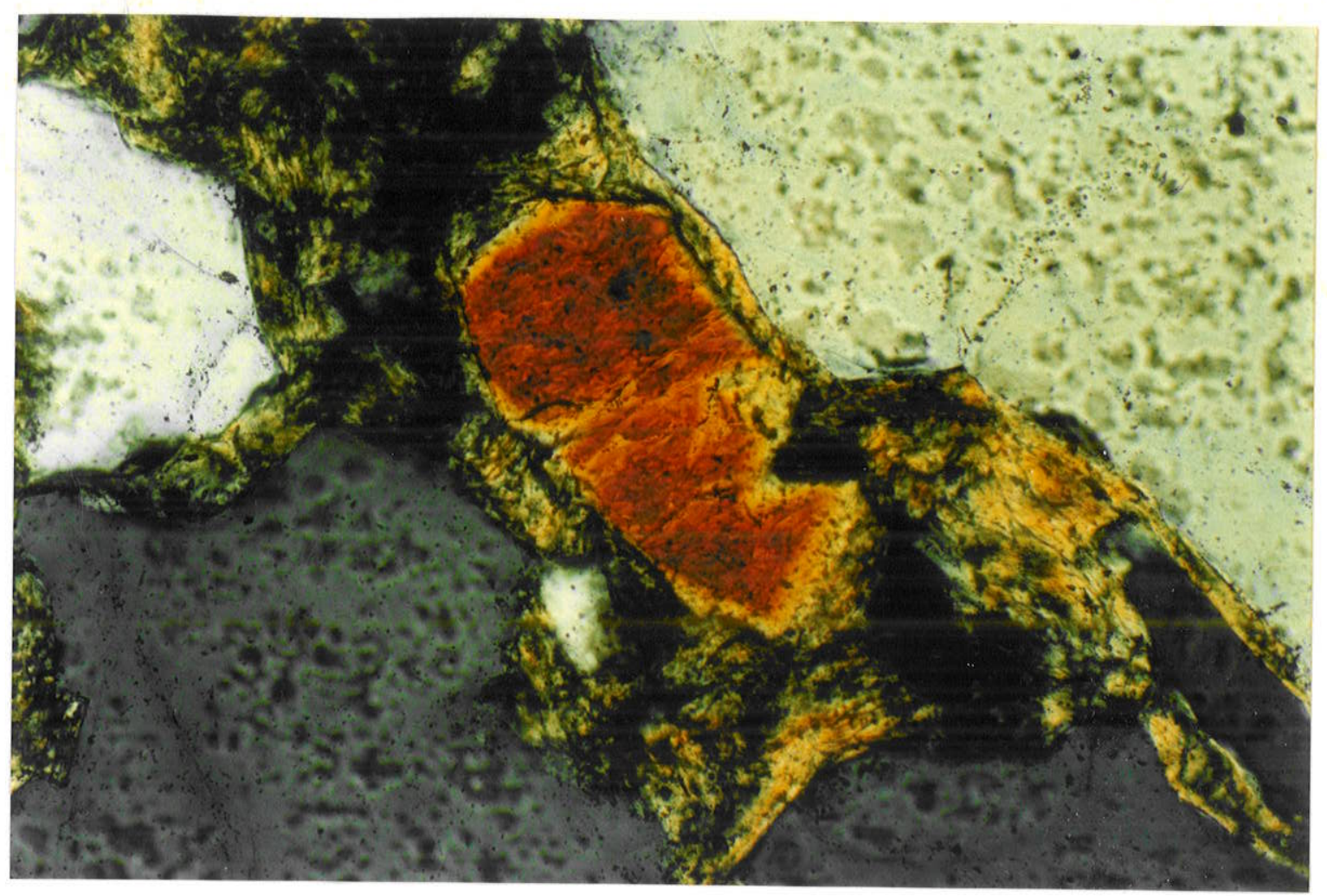

Fotografia 7. Grão de turmalina (centro da foto ) envolto por matriz argilosa. Sondagem Piqueri, 7,5 metros de profundidade, Zona Leste. Fotomicrografia. Nicóis cruzados. Aumento $20 \mathrm{X}$.

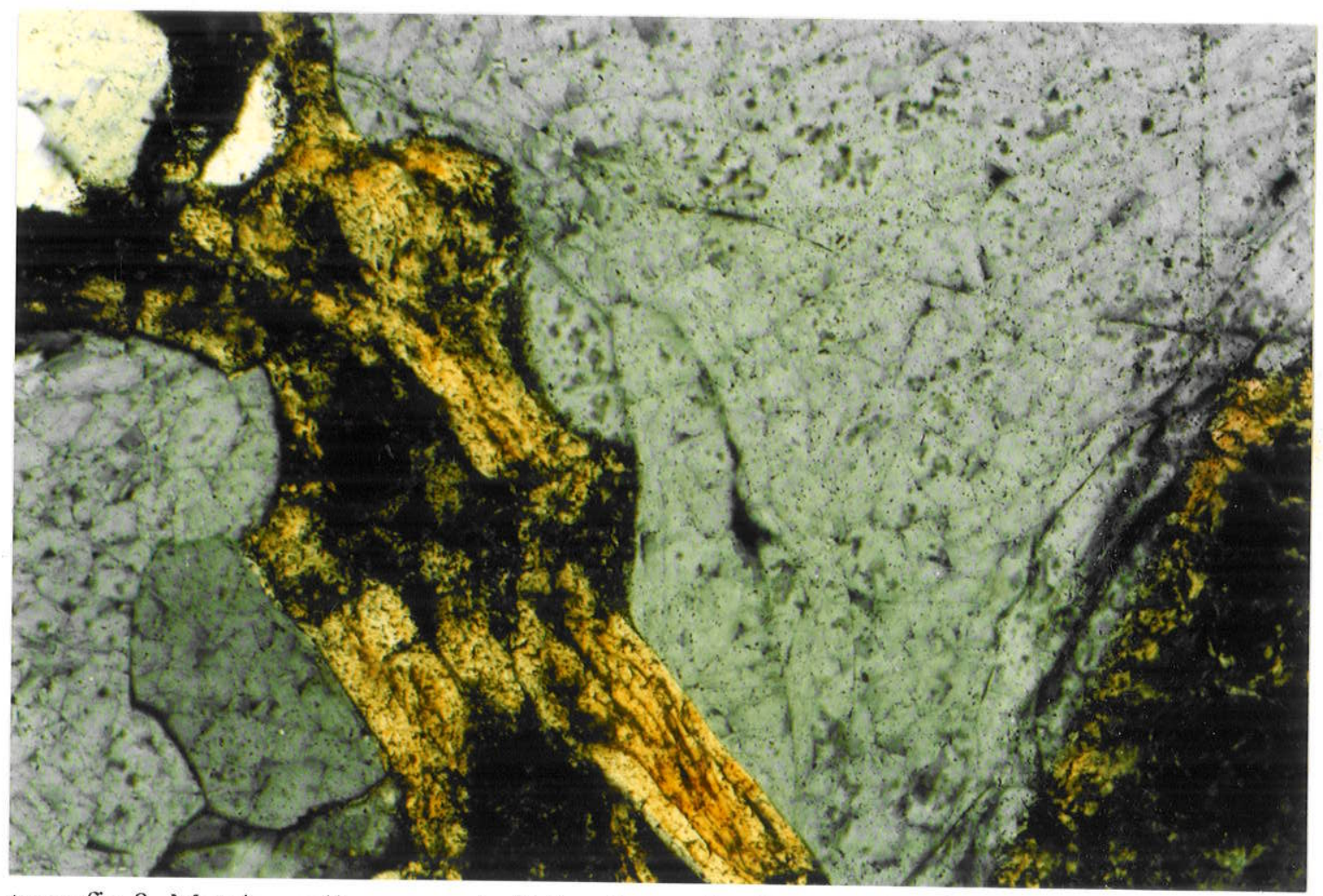

Fotografia 8. Matriz argilosa com indícios de recristalização. Sondagem Piqueri, 7,5 metros de profundidade, Zona Leste. Fotomicrografia. nicóis cruzados. Aumento 20 X. 
A análise dos difratogramas de Raios $X$ da areia conglomerática endurecida (amostra PI7.5) mostrou a presença de quartzo, feldspato e caulinita. A fração argila desse sedimento apresentou picos bem definidos de caulinita, além de esmectita e mica.

Segundo RICCOMINI (1989) e RICCOMINI \& COIMBRA (1992), as esmectitas constituem-se nos argilominerais principais dos depósitos fanglomeráticos da Formação Resende. No entanto, por se tratar de sedimento submetido a condições intempéricas, verificou-se nas análises de Microscopia Eletrônica de Varredura na amostra PI-7.5 e nas demais analisadas, descritas a seguir, a presença predominante de caulinita em finas placas com bordas por vezes arredondadas, provavelmente originadas como produto de alteração de esmectitas (Fotografias 9 e 10). Foram notadas ainda piritas framboidais, formadas provavelmente em condições de eodiagênese, com desenvolvimento da pirita nos poros dos sedimentos (Fotografia 11). A ocorrência de piritas framboidais foram descritas por RICCOMINI (1989) em sedimentos da denominada fácies "C" (Formação Tremembé).

Não foram observados na amostra PI-7.5 minerais como dickita e barita, encontrados por RICCOMINI et al. (1988) nos sedimentos hidrotermalizados do Parque D. Pedro II. No entanto por se tratar de sedimento litificado (endurecido) não se deve descartar a hipótese de que os depósitos encontrados no Parque Piqueri tenham sido afetados por atividades hidrotermais. Outro argumento em favor dessa hipótese seria a própria localização desses sedimentos, próxima à Falha do Buquira, de direção NE, a qual poderia ter propiciado a percolação de possíveis fluidos hidrotermais.

Foram efetuados ainda difratogramas de Raios X e MEV de outras amostras coletadas em sedimentos da Formação Resende. As amostras PI 12.78 e PI 10.48 foram coletadas em testemunhos da sondagem executada no Parque Piqueri correspondendo respectivamente a lamito argiloso a lamito argiloso a argilito. Os difratogramas da amostra PI 12.78 apontaram a presença de caulinita, esmectita e mica. Nas análises de MEV notou-se o predominio da caulinita apresentando-se em pequenas placas com bordas arredondadas (Fotografia 12).

Foram identificados na amostra PI 10.48 caulinita com bordas angulosas, provavelmente hexagonais (Fotografia 13) e clorita neoformada em forma de pequenos repolhos sobre grão de quartzo (Fotografia 14) semelhantes às descritas por RICCOMINI (1989) em sedimentos lacustres da fácies "C" em Tremembé. 
Os difratogramas de Raios X da amostra PI 10.48 apontaram picos bem formados de caulinita e mica. Esses mesmos minerais foram identificados na amostra Tr-1.55 coletada em testemunhos de sondagem efetuada à Rua Colômbia, Jardim Paulistano. As placas de caulinita encontradas nessa amostra são mostradas na Fotografia 15.

Em apêndice são apresentados os difratogramas de Raios $X$ mais representativos das amostras analisadas, uma vez que os minerais identificados são bastante comuns e praticamente não há variação na identificação dos mesmos nas amostras.

Os depósitos fanglomeráticos da Formação Resende foram depositados em diferentes fases de sedimentação da bacia, sendo a principal relacionada com seu preenchimento inicial quando da abertura do Rifi Continental do Sudeste do Brasil, e desenvolvimento dos leques aluviais. No entanto, registram-se na bacia pulsos, provavelmente de pequena ordem, mesmo após a deposição da Formação São Paulo, já na fase de colmatação da bacia, conforme já mencionado por outros autores (RICCOMINI 1989, RICCOMINI \& COIMBRA 1992).

Em uma pequena ilha, próxima a Ilha dos Eucaliptos, situada na represa de Guarapiranga, Zona Sul, verificou-se a presença de lamitos avermelhados da Formação Resende assentados sobre bancos argilosos de coloração arroxeada da Formação São Paulo (Fotografia 16), mostrando deposição tardia relacionada a movimentações tectônicas pós-deposicionais, ou mesmo associadas a condições climáticas (secas com chuvas concentradas) e morfológicas (relevo acidentado) favoráveis a geração de depósitos fanglomeráticos.

Evidências de retrabalhamento foram verificados à Rua. Itaiteva, no Bairro do Morumbi, onde notou-se sedimentos intemperizados, com coloração vermelho-amarronzado, aspecto de brecha, com grânulos a seixos de quartzo, quartzito e lamitos.

Apesar dos sedimentos da Formação Resende não terem sido datados na área de ocorrência da Bacia de São Paulo, através da palinologia, é admitida a idade oligocênica para esta unidade pois os sedimentos já analisados (eg. MELO et al. 1986; RICCOMINI 1989; LIMA \& MELO 1989; LIMA et al. 1994) ou correlacionam-se ou encontram-se interdigitados com a unidade em questão. 


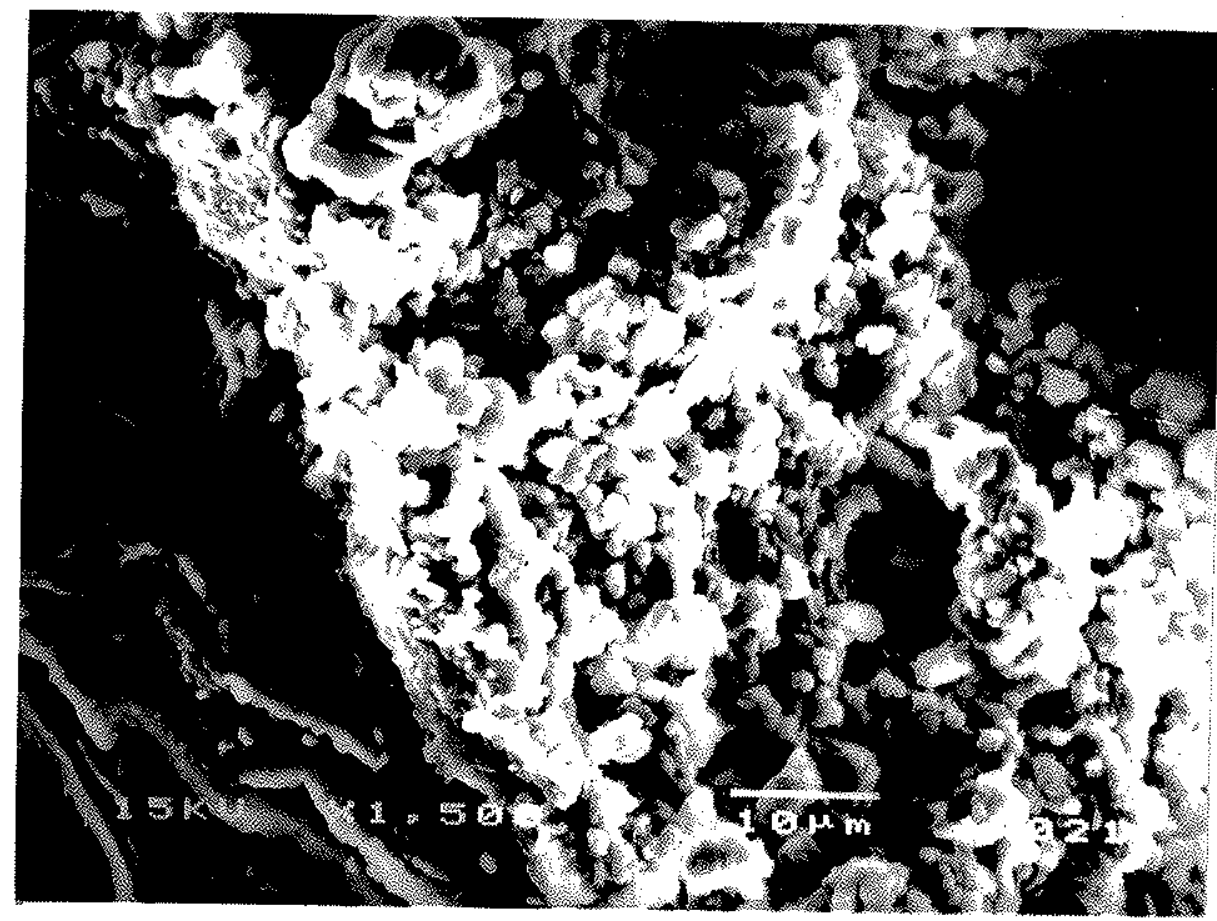

Fotografia 9. Caulinitas em finas placas com bordas arredondadas. Sondagem Piqueri, profundidade 7,5 metros, zona leste. MEV.

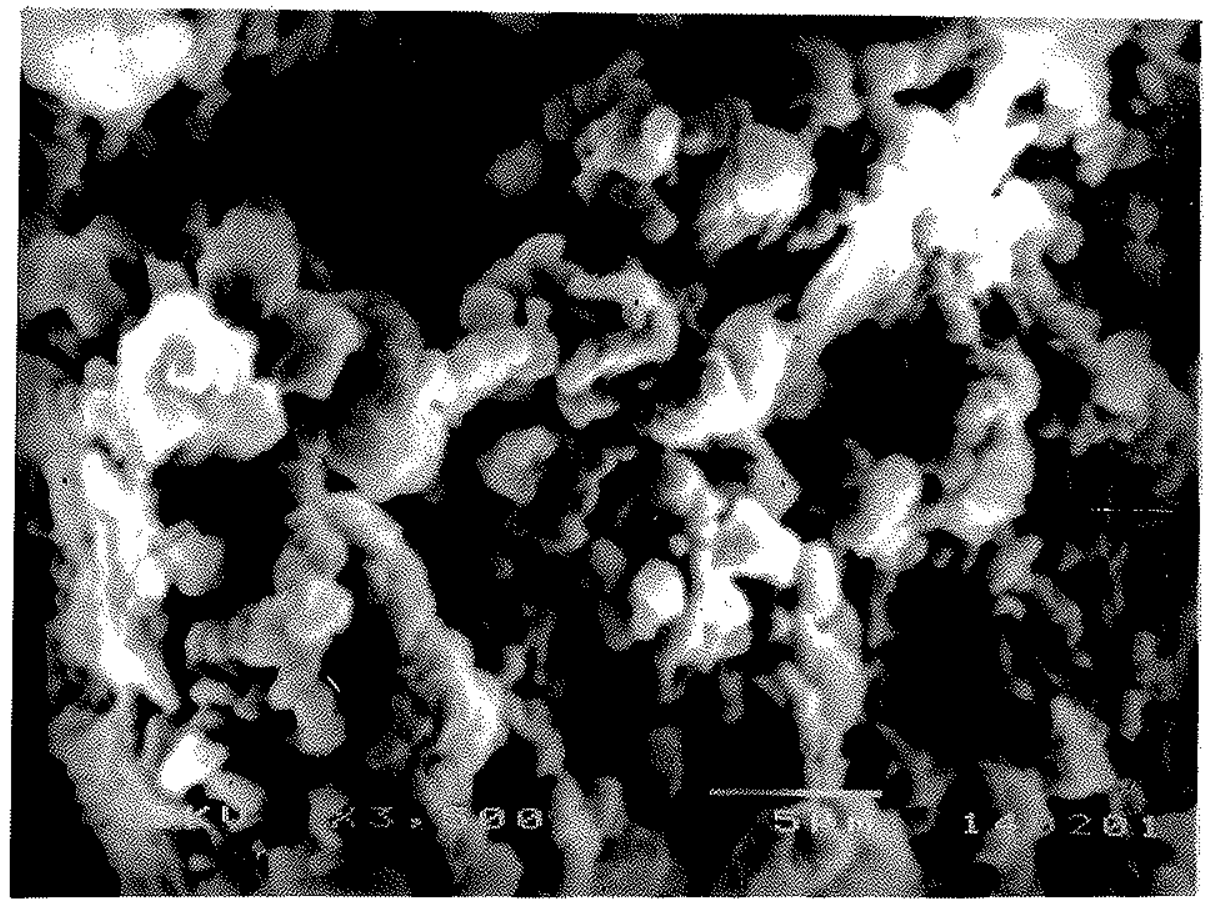

Fotografia 10. Detalhe da foto anterior 


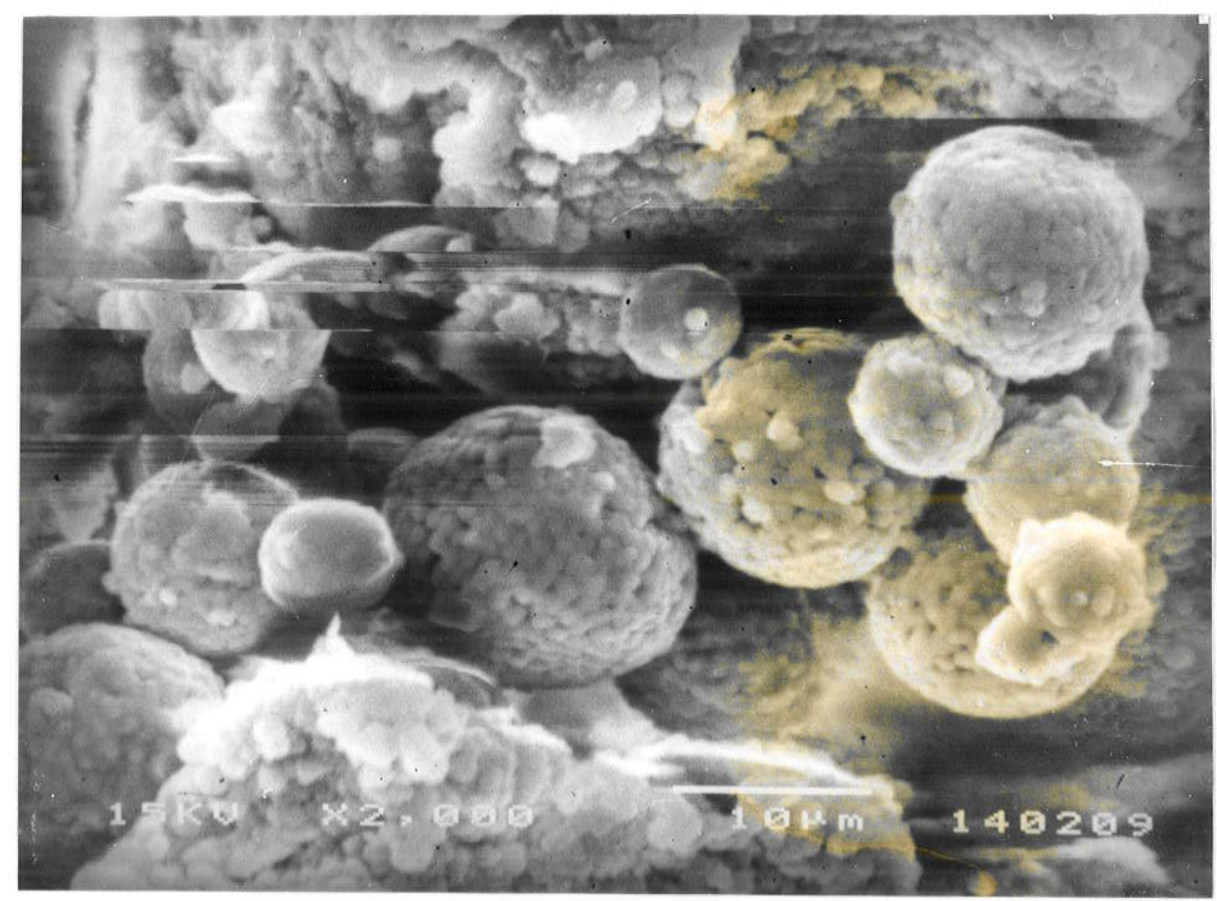

Fotografia 11. Piritas framboidais formada nos poros do sedimento. Sondagem Piqueri, profundidade 7,5 metros, zona leste. MEV.

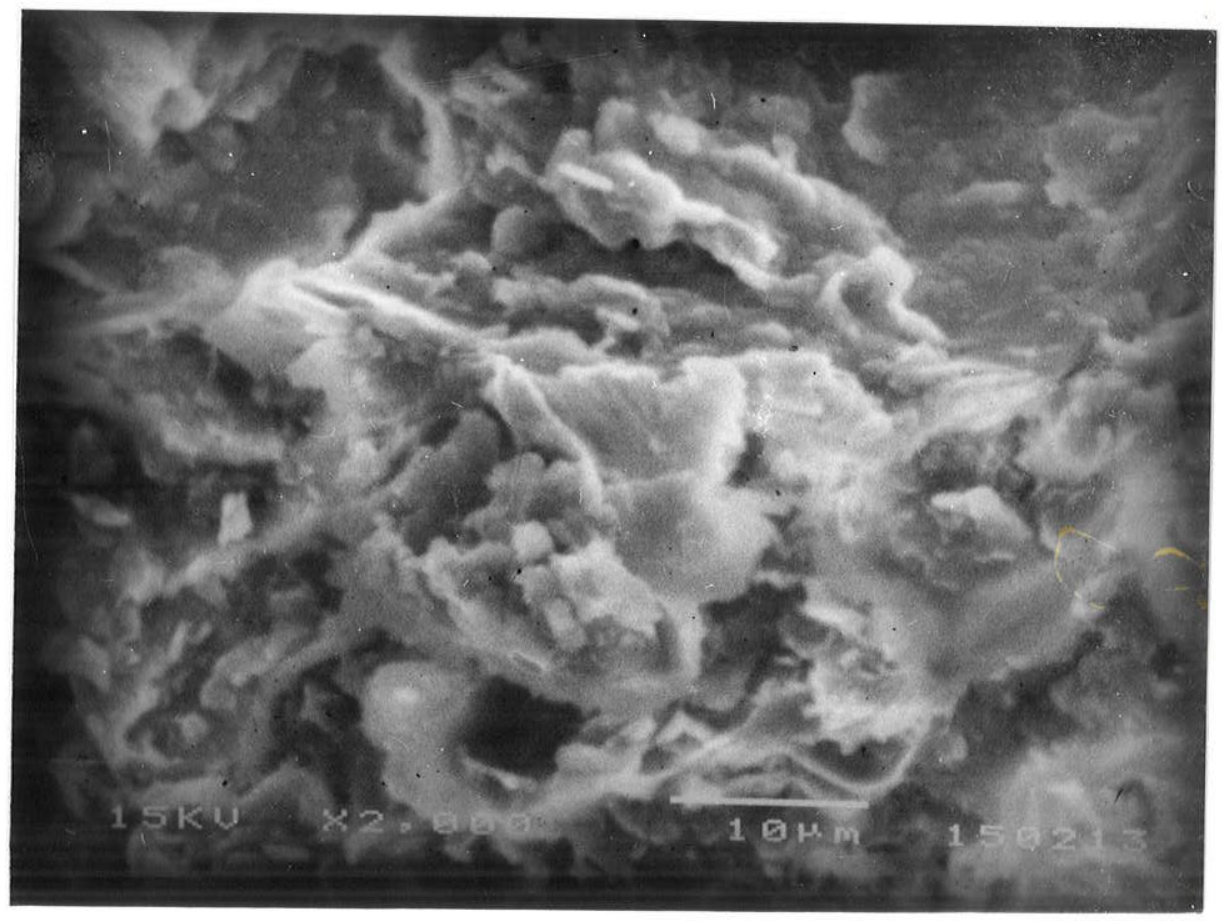

Fotografia 12. Caulinitas em finas placas de com bordas arredondadas ( área central da imagem) MEV 


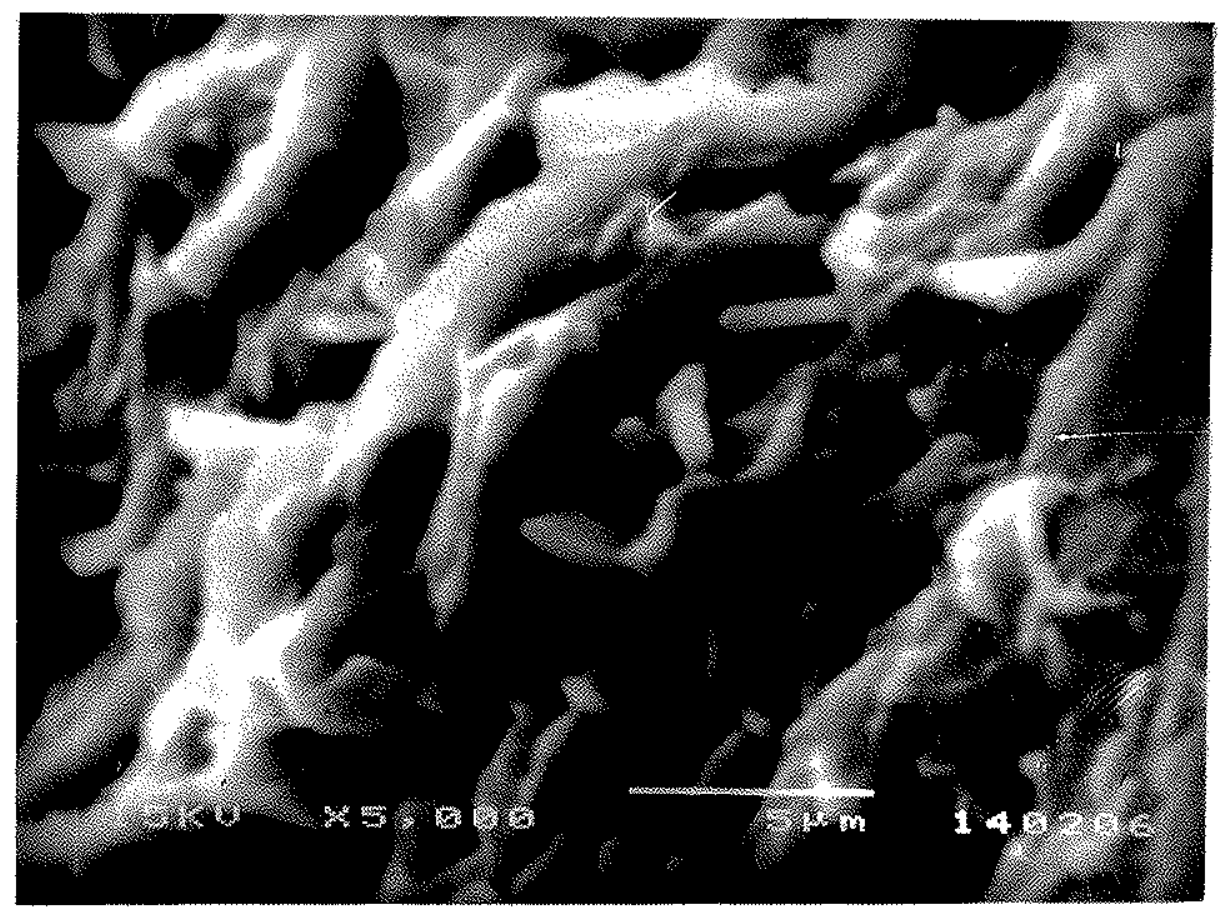

Fotografia 13. Caulinitas com bordas angulosas, provavelmente hexagonais. MEV.

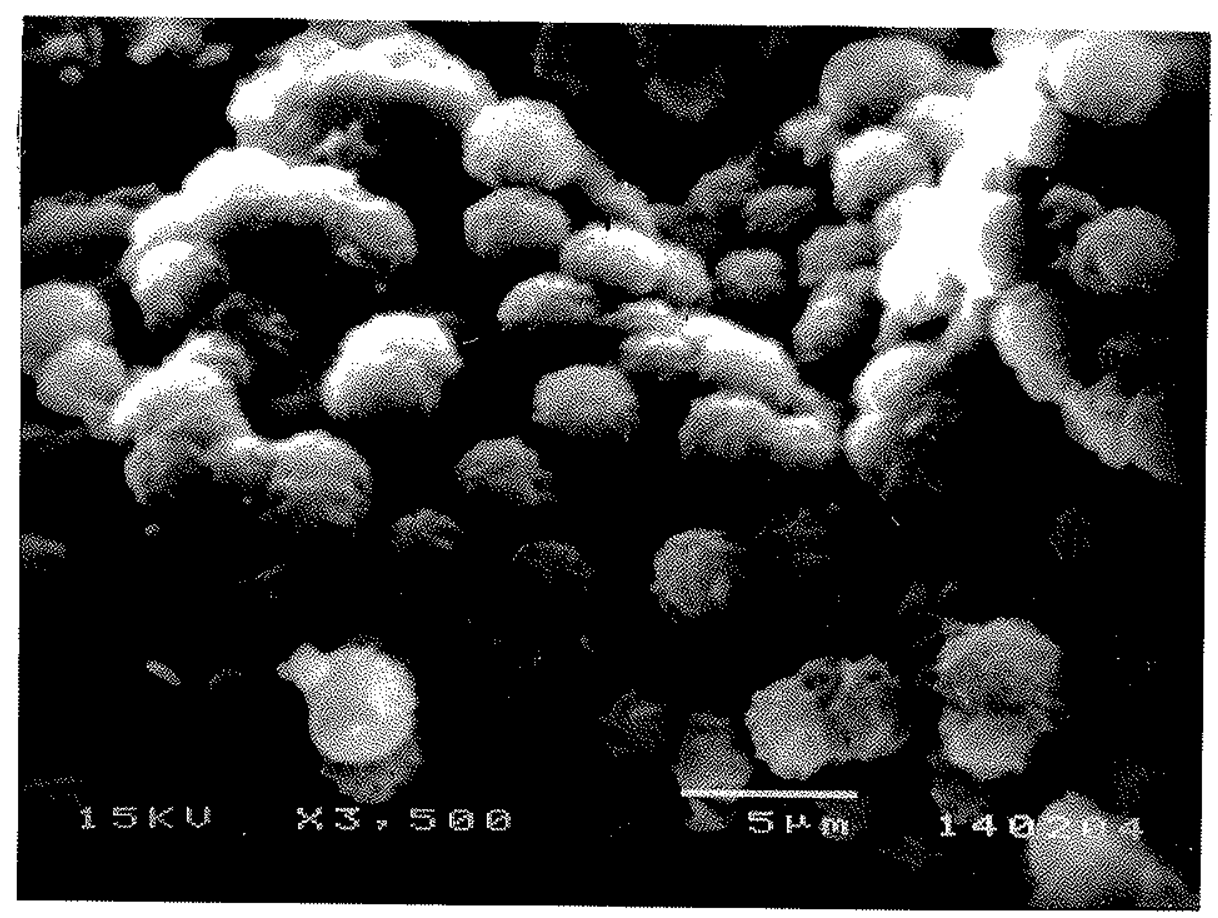

Fotografia 14. Clorita neoformada em forma de pequenos repolhos sobre grão de quartzo. MEV. 


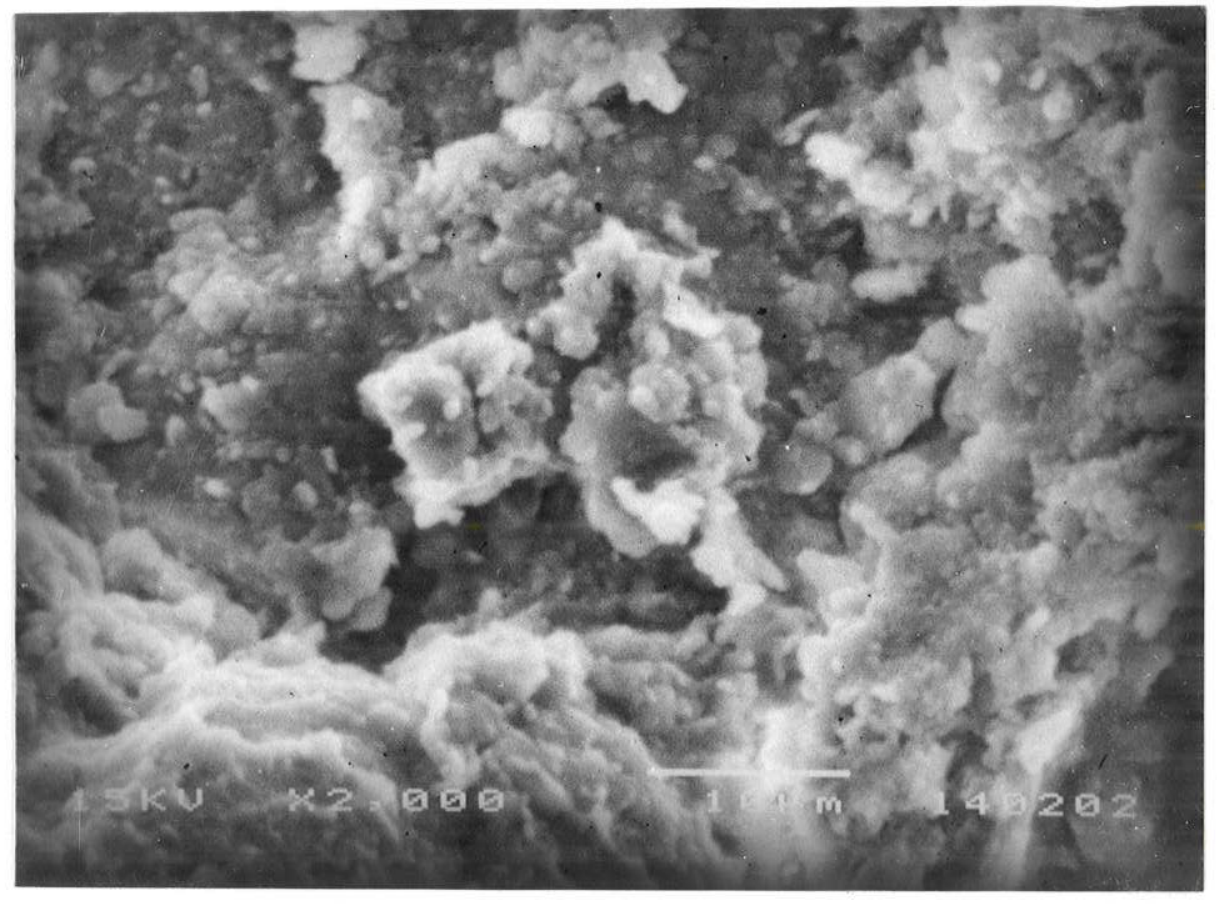

Fotografia 15. Finas placas de caulinitas com bordas arredondadas ao centro da imagem. MEV.

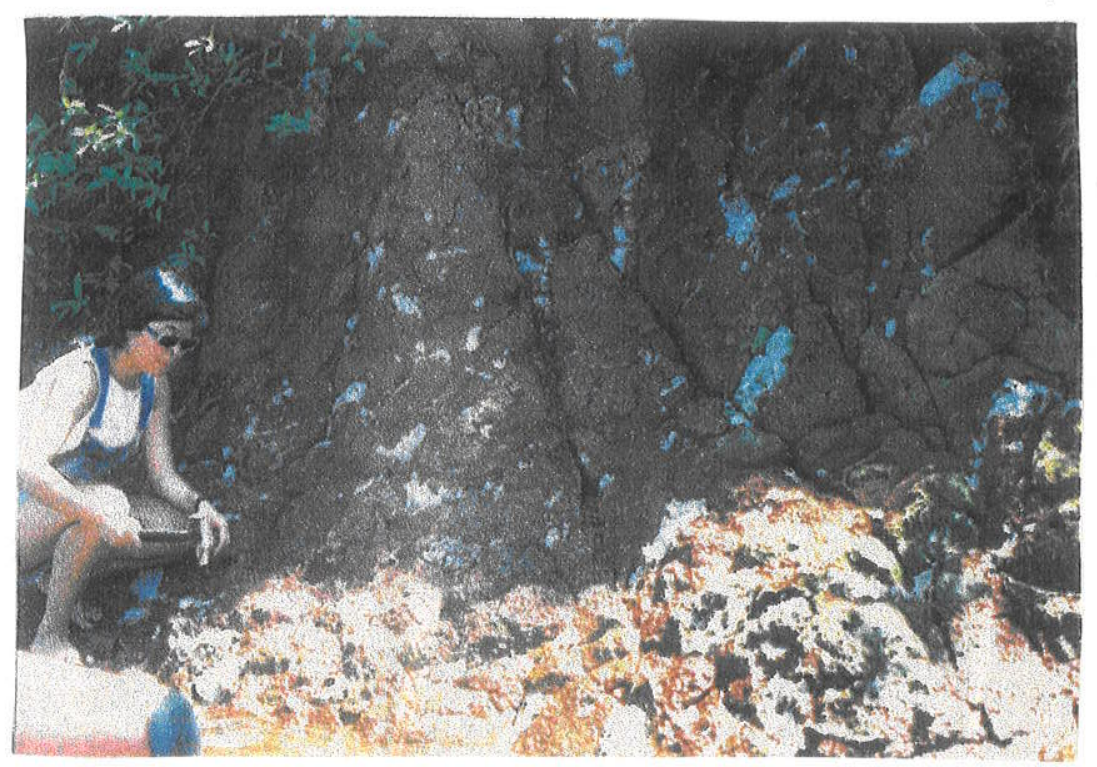

Fotografia 16. Sedimentos lamíticos da Formação Resende assentados sobre depósitos argilosos da Formação São Paulo. Ilha Menor, Capela do Socorro. 
A respeito de paleoclimas associados aos depósitos da Formação Resende, admite-se condições de semi-aridez, com periodos de chuvas concentradas (MELO et al. 1986; RICCOMINI 1989). Recente descoberta de caliche na bacia corrobora a hipótese de clima seco (RICCOMINI \& COIMBRA 1992).

\subsubsection{FORMAÇÃO TREMEMBÉ}

Os depósitos da Formação Tremembé consistem em camadas tabulares de argilas siltosas de coloração preta a cinza esverdeadas (RICCOMINI 1989), de localização restrita na Bacia de São Paulo, próxima à Estação Barra Funda do METRÔ, na Zona Oeste de São Paulo. Exibe a unidade uma área de aproximadamente $4 \mathrm{~km}^{2}$, revelando espessuras de até $60 \mathrm{~m}$ (TAKIYA 1991).

Os sedimentos da Formação Tremembé têm ocorrência mais expressiva na porção central da Bacia de Taubaté, onde pode ser caracterizado um ambiente deposicional lacustre do tipo playalake (RICCOMINI 1989).

Recentemente, nova ocorrência desses sedimentos foi descrita por RICCOMINI \& COIMBRA (1992), na região do Parque Antártica e na Rua Oriente, no Pari, levando os autores a sugerir uma maior extensão do sistema lacustre na bacia, como já manifestado por TAKIYA (1991).

Em relação aos argilominerais descritos na Formação Tremembé, ressalta-se a presença de esmectita expansiva, além de ocorrência mais restrita de illita com aspecto micáceo, associada a cloritas, e halloisitas, encontradas nas fácies de inunditos, na fração argila de arenitos grossos e conglomeráticos os quais encontram-se intercalados aos depósitos argilosos lacustres (RICOMINI 1989, RICCOMINI et al. 1996, SANT'ANNA \& VALARELLI 1996).

RICCOMINI et al. (1996) e SANT'ANNA \& VALARELLI (1996), atribuiram significado paleoclimático, à presença de halloisitas autigênicas, denotando sazonalidade de chuvas, com estações bem definidas, sob condições de semi-aridez e calmaria tectônica (RICCOMINI 1989).

As análises palinológicas efetuadas nos sedimentos dessa unidade próxima a estação Barra Funda do METRO, no Bairro da Barra Funda, indicaram para a mesma idade oligocênica (LIMA \& MELO 1989). 


\subsubsection{FORMAÇÃO SÃO PAULO}

A Formação São Paulo caracteriza-se por depósitos de sistema fluvial meandrante com planícies de inundação bem desenvolvida. Litologicamente a Formação São Paulo é composta por conglomerados, arenitos com estratificação plano-paralela, passando a acanaladas e cruzadas, gradando para siltitos laminados e argilitos, caracterizando depósitos de canal, barra de pontal e planície de inundação. Em campo, nota-se geralmente truncamentos na seqüência granodecrescente apontada. Feições de rompimento de dique marginal foram também observadas em campo. Esses ultimos apresentam sequêencia areno-conglomerática sobreposta por espesso pacote argiloso.

A unidade tem importante ocorrência em área na bacia. Seus depósitos encontram-se comumente associados a couraças ferruginosas (SUGUIO \& BARBOUR 1969; SÍGOLO \& OHNUMA 1990) sustentando altas colinas, como verificado no espigão central situado na região da Av. Paulista - Sumaré (TAKIYA 1991).

A ocorrência dessa unidade em cotas mais altas é explicada também devido a sua correlação com os últimos estágios de sedimentação da bacia, atribuídos aos processos de colmatação da mesma (RICCOMINI 1989). Segundo TAKIYA (1991) a unidade aflora acima da cota $780 \mathrm{~m}$, e de acordo com ROCHA (1995) os gráficos de distribuição de argila apresentam valores elevados acima da cota $760 \mathrm{~m}$, que poderia representar ocorrência de sedimentos da Formação São Paulo.

Os sedimentos dessa unidade foram observados principalmente na Zona Oeste, na Cidade Universitária, Rio Pequeno, Lapa, Pacaembu (Fotografias 17, 18, e 19), Sumaré e Vila Jataí, onde, conforme RICCOMINI (1989) foi descrita a seção-tipo da unidade por SUGUIO \& BARBOUR (1969) (Figura 9). Na zona sul da cidade, os depósitos da unidade foram observados na região do Jabaquara e Capela do Socorro, sendo ainda encontrados nas Zonas Leste, em Sapopemba, e Norte, em Santana. As fácies associadas aos ambientes de barra de pontal e planicie de inundação foram comumente notadas nos trabalhos de campo e através dos perfis de sondagem observados.

Por ocasião da execução da obra para construção do reservatório de águas pluviais (atualmente finalizada), realizou-se uma grande cava em frente ao estádio do Pacaembu colocando em exposição pacotes de mais de $10 \mathrm{~m}$ de espessura de sedimentos da Formação São Paulo, além de prováveis solos de alteração do embasamento (Fotografias 17, 18 e 19). Esses depósitos são constituidos por sedimentos pelíticos de planície de inundação de coloração predominantemente 
arroxeada e amarelada (Fotografia 17) associados lateralmente a espessos pacotes de areias média a grossa com matriz argilosa, depositados em condições de maior energia, aqui atribuídas ao subambiente de barra de pontal (Fotografias 18, 19 e figura 10).

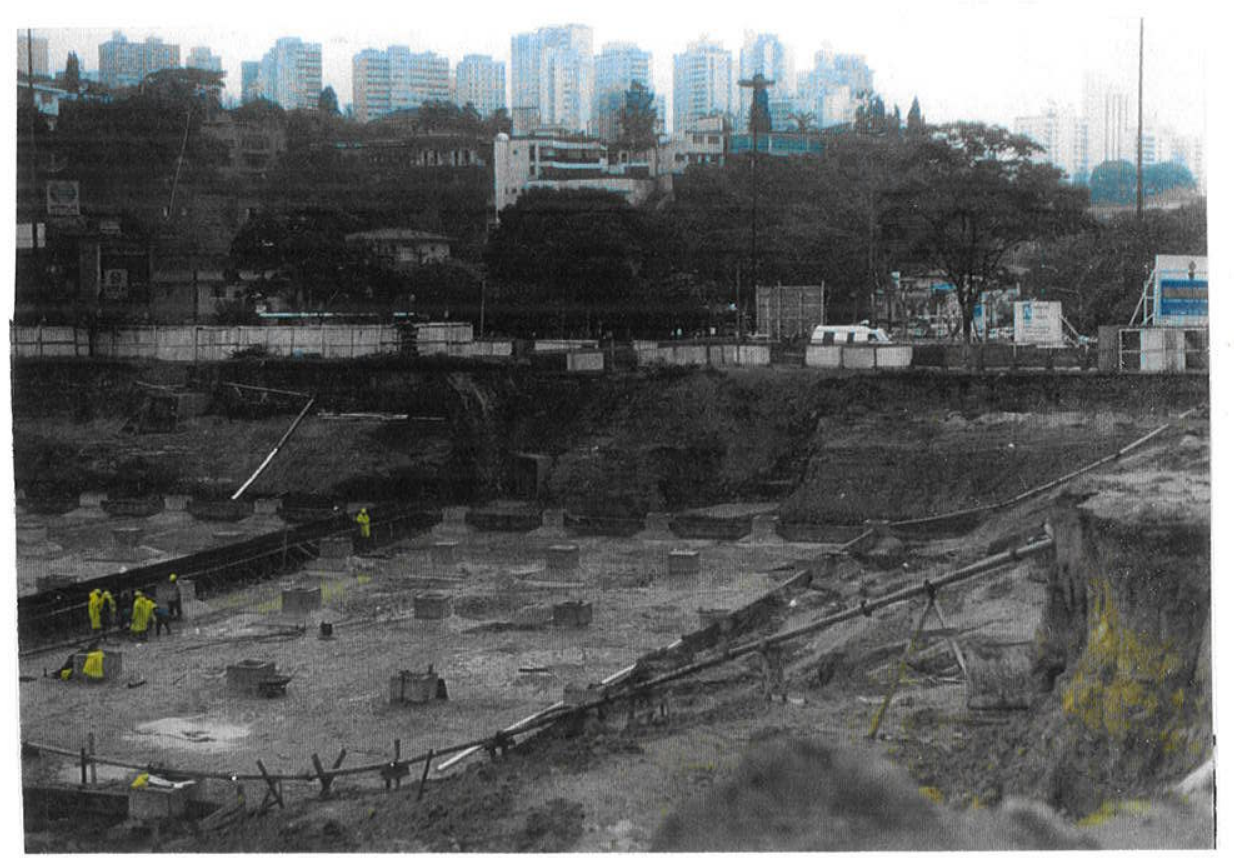

Fotografia 17. Obra para construção do reservatório da Praça Charles Müller, Pacaembu. No canto direito observa-se sedimentos da Formação São Paulo. No centro da foto, nota-se prováveis solos de alteração do embasamento. 


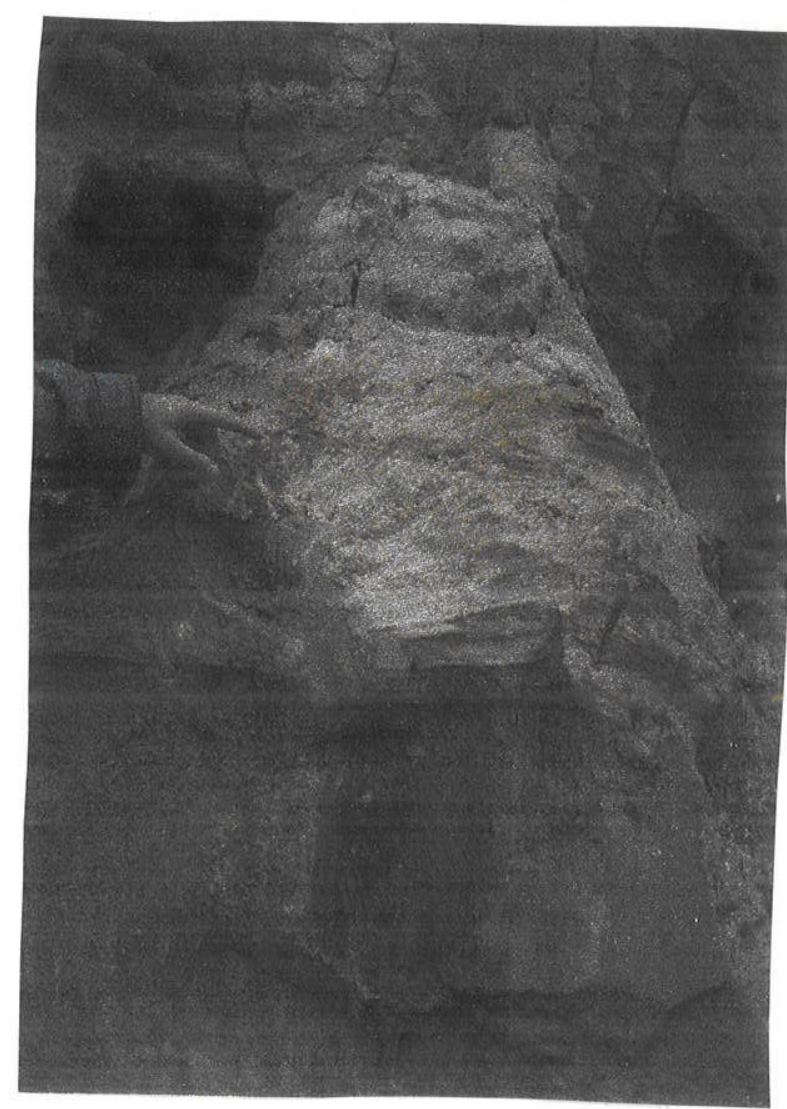

Fotografia 18. Conglomerado polimítico com grânulos a seixos de quartzo, gnaisse e feldspato, sob camada de argila arroxeada. Formação São Paulo. Praça Charles Müller, Pacaembu.

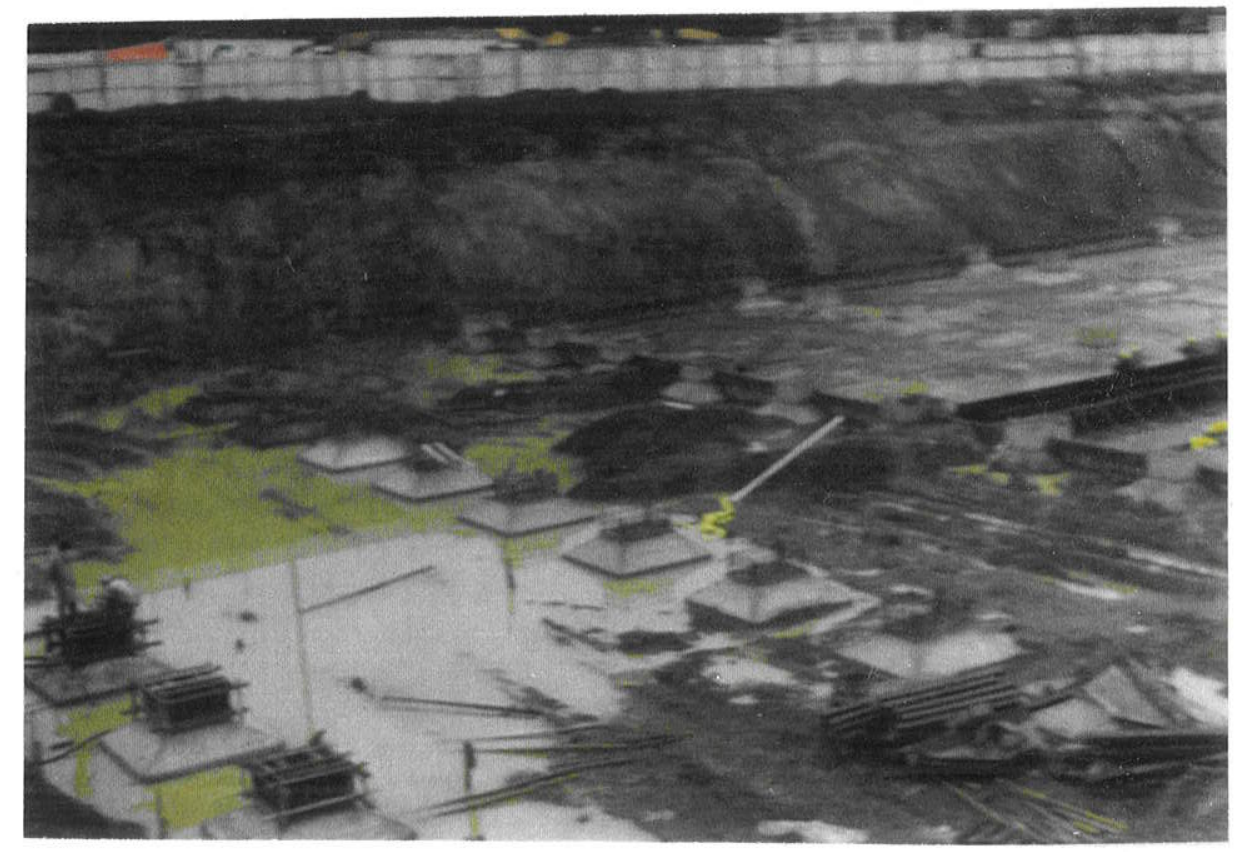

Fotografia 19. Obra para construção do Reservatório da Praça Charles Müller. Vista geral da cava. 
Mapas de isólitas confeccionados por TAKIYA ( 1991) indicam na zona sul de São Paulo, na região do Jabaquara, sedimentos arenosos, associados lateralmente a espessas camadas de argila, apresentando todo o pacote, até $100 \mathrm{~m}$ de espessura, podendo representar sedimentos de sistema fluvial meandrante da Formação São Paulo (TAKIYA 1991).

São admitidas condições climáticas úmidas e calmaria tectônica para a deposição desta unidade (RICCOMINI 1989; TAKIYA 1991; RICCOMINI et al. 1992) de idade oligocênica, revelada por análises palinológicas realizadas em litofácies correlacionáveis, segundo RICCOMINI (1989), à Formação São Paulo, em Guararema, Bacia de Taubaté (LIMA el al. 1985) e na Bacia de Bonfim (LIMA \& DINO 1985).

Foram efetuadas análises de difratogramas de raios X (amostra H-BSP-12) e Microscopia Eletrônica de Varredura em amostras de argila e areia, de fácies de barra de pontal da Formação São Paulo, coletadas em afloramento situado no Conjunto Habitacional Garagem, em São Miguel Paulista.

As análises revelaram presença de caulinita como argilomineral predominante nas duas amostras analisadas. As imagens obtidas no MEV exibiram a caulinita disposta em pequenas placas com bordas arredondadas. A presença de caulinitas detríticas na Formação São Paulo foi descrita anteriormente por RICCOMINI (1989). 


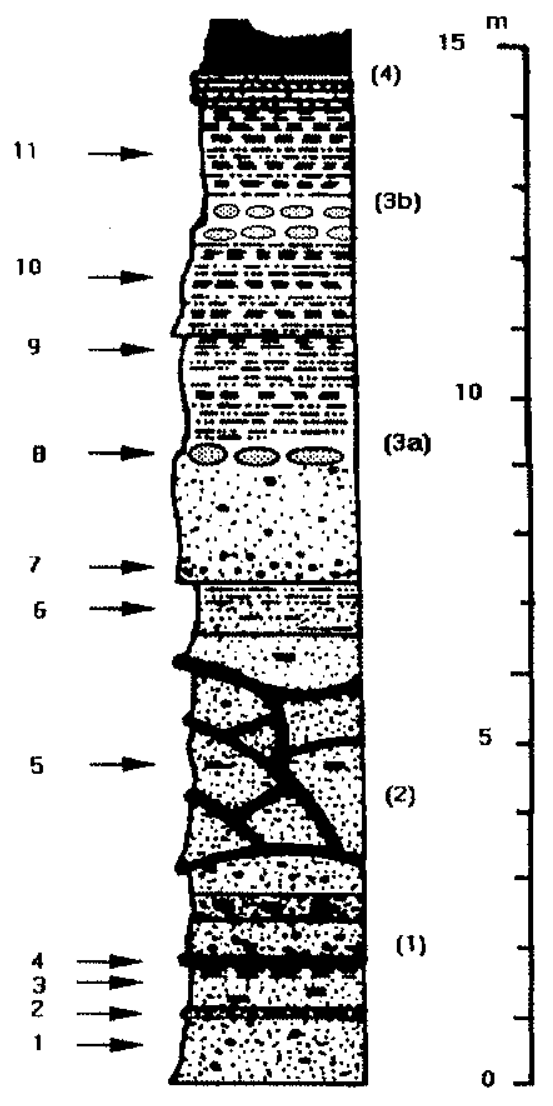

LEGENDA: 1, 3, 10, 11. arenito argiloso; 2, 5, 7. arenito mais puro; 4. argilito siltico-arenoso; 8 . siltito argiloso; 6,9. argilitio siltito. Nível com pelotas de argila a $2,5 \mathrm{~m}$; (1) camada de arenito com cimento limonitico; (2) camadas limoniticas anastomosadas; (3a e 3b) crostas de concreções limoníticas botrioidais; (4) siltito argiloso limonitizado.

Figura 9. Seção tipo da formação São Paulo, conforme definida por RICCOMINI (1989), com base na seção colunar de SUGUIO \& BARBOUR (1969, p. 164), localizada abaixo da caixa de água da Rua Heitor Penteado, Vila Jataí, São Paulo. 


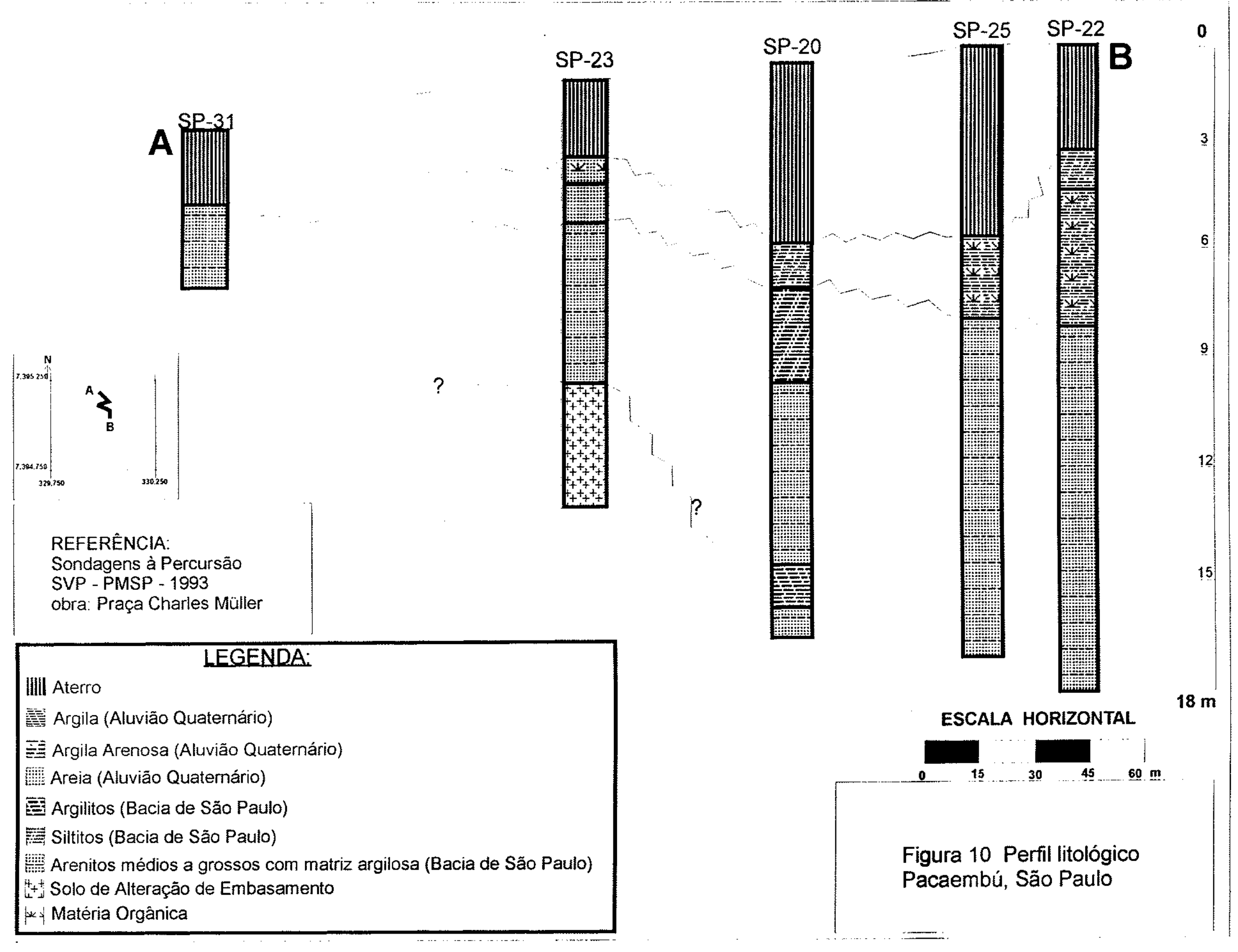




\subsubsection{FORMAÇÃO ITAQUAQUECETUBA}

Os depósitos sedimentares da Formação Itaquaquecetuba atribuídos a sistema fluvial entrelaçado associado a leques aluviais são observados, principalmente, em cotas abaixo de $710 \mathrm{~m}$, sob os sedimentos aluviais dos rios Tietê, Tamanduateí e Pinheiros. (RICOMINI 1989; TAKIYA 1991; RICCOMINI \& COIMBRA 1992).

Esses sedimentos primeiramente descritos por JUNQUEIRA (1969), SUGUIO \& TAKAHASHI (1970), SUGUIO et al. (1971) e BIGARELLA (1971), foram formalizados por COIMBRA et al. (1983) como Formação Itaquaquecetuba.

Constituem-se predominantemente por arenitos grossos arcoseanos, mal a medianamente selecionados, exibindo estratificações cruzadas tabulares e acanaladas. Estes estratos podem conter niveis argilo-siltosos, eventuaimente arenosos, de coloração castanho-escura, ricos em matéria orgânica apresentando níveis de conglomerado com seixos de quartzo e quartzito bem arredondados, conforme pode ser observado na seção tipo desta unidade, em Itaquaquecetuba ( RICCOMINI 1989) (Figura 11).

Um segundo tipo de conglomerado, sustentado por clastos, indicado por COIMBRA et al. (1983), observado na unidade, exibe principalmente seixos de quartzo e quartzito e pouca matriz arenosa. RICCOMINI (1989) e RICCOMINI \& COIMBRA (1992) descrevem ainda três litofácies nesta unidade, são elas: fácies de arenito médio a fino maciços, mal selecionados, com estrutura almofadada, provavelmente gerados por processos de fluidificação de barras arenosas com estratificação cruzada; fácies de lamitos maciços e siltitos arenosos, que ocorrem associados a fácies de arenito maciço anteriormente descrita; fácies de blocos subangulares de folhelhos siltosos a arenito marrom escuro, com até $3 \mathrm{~m}$ de espessura, e pedaços de tronco fósseis, além de clastos menores, de quartzo e quartzito em sua maioria, com dimensões centimétricas até decimétricas.

Segundo observado por TAKIYA (1991), em mapas de isópacas, isólitas e porcentagem, observam-se áreas apresentando elevada porcentagem de areia, superior a $70 \%$, e baixa porcentagem de argila ou lamito, revelando espessuras variando entre 20 e $130 \mathrm{~m}$, encontradas sob os aluviões atuais dos rios Tietê (próximo ao Parque São Jorge) e Pinheiros (em Pinheiros) e poderiam representar sedimentos da Formação Itaquaquecetuba.

Ocorrência desses depósitos em Carapicuiba no vale do rio Tietê são descritos por COIMBRA et al. (1983) (ANEXO A). 
$\mathrm{Na}$ atual planície do rio Pinheiros, na Ráia Olímpica da USP, onde foram realizados os primeiros estudos sobre a Formação Itaquaquecetuba, foi descrito um perfil de 40,79 m (TAKIYA 1991), através de testemunhos de sondagem realizada pelo Centro de Pesquisas de Águas Subterrâneas CEPAS, do Instituto de Geociências da USP, onde foram executadas análises granulométricas e palinológicas em diferentes níveis, assinalados na (Figura 12).

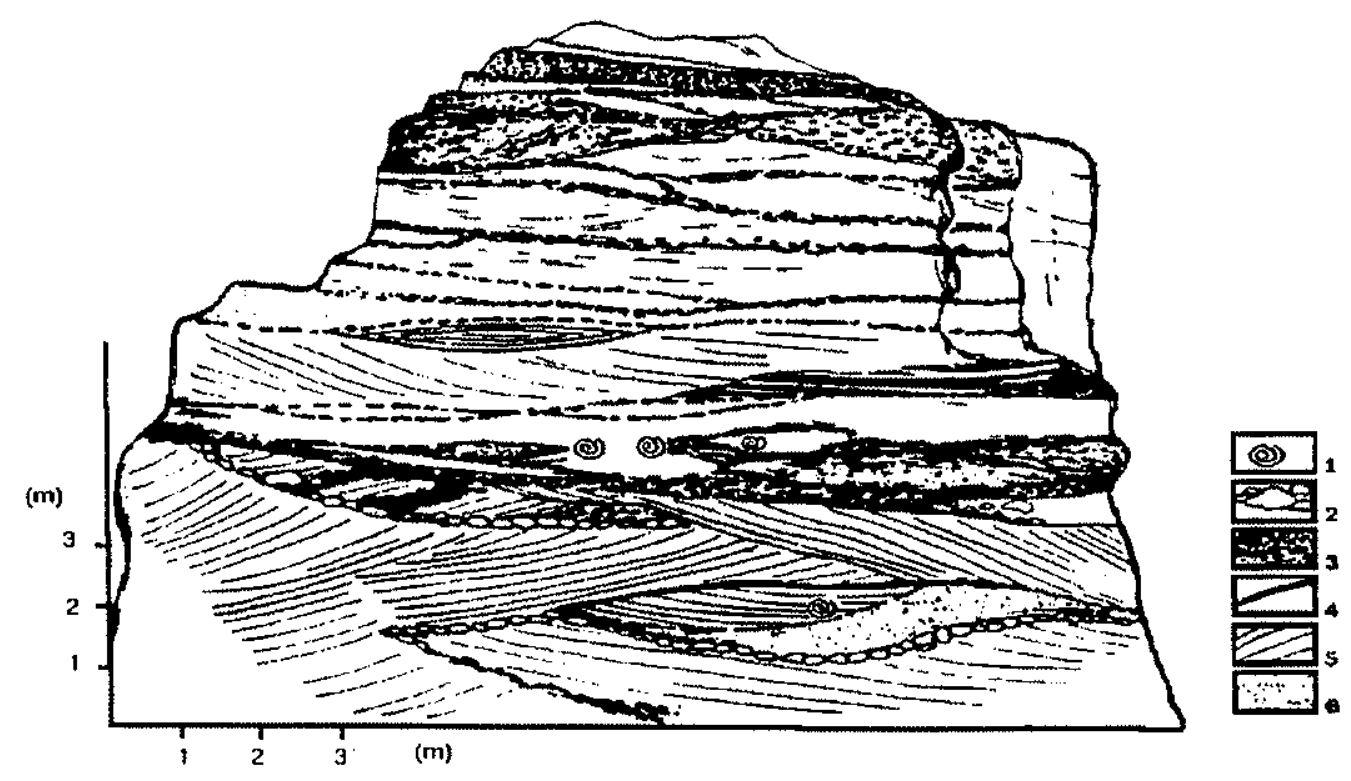

Figura 11. Seção-tipo da Formação Itaquaquecetuba (RICCOMINI 1989). 1. troncos fósseis carbonificados; 2. níveis de brechas com clastos de argila; 3. conglomerados; 4. níveis com concentração de fragmentos milimétricos arenosos finos a siltosos, de coloração marrom, ricos em matéria orgânica; 6 . arenitos maciços de granulação fina a média.

Nesse perfil são descritos sedimentos predominantemente arenosos (areia fina a grossa) a conglomeráticos de coloração esbranquiçada a alaranjada com intercalações de lamito cinza esverdeado, onde foram coletadas amostras para análise palinológica, descrita adiante.

Foi aventada ainda a possibilidade de ocorrência dessa unidade próxima a atual calha do Rio Tamanduateí por RICCOMINI et al. (1992) e ROCHA \& CELESTINO ( 1992) devido a 
semelhança encontrada entre os sedimentos descritos em sondagens executadas pelo METRO na região do Pari, e aqueles pertencentes a Formação Itaquaquecetuba.

Foi executado ainda nessa região um túnel pela ELETROPAULO que atravessou os bairros do Brás e Pari e o Rio Tamanduateí. Os perfis descritos na área foram apresentados por COZZOLINO et al. (1994) e mostram camadas de argila interrompidas na zona situada a leste da margem direita do Rio Tamanduateí. Os autores indicam a presença de falhamentos no local entre as camadas apresentando intercalações areia/argila dos depósitos predominantemente arenosos.

Esses depósitos predominantemente arenosos e conglomeráticos apresentados por ROCHA \& CELESTINO (1992) e COZZOLINO et al. (1994) são aqui interpretados como pertencentes a Formação Itaquaquecetuba, em concordância os autores anteriormente citados (RICCOMINI et al. 1992, ROCHA \& CELESTINO 1992). Dentre as principais características desses depósitos, presentes também nos sedimentos da Formação Itaquaquecetuba pode-se citar: a forma de ocorrência restrita, sob os aluviões do Rio Tamanduateí, associada a falhamentos; predominância de sedimentos arenosos e conglomeráticos, típicos de sistema fluvial entrelaçado; presença de sulfetos e troncos fósseis descritos somente em sedimentos da Formação Itaquaquecetuba, na Bacia de São Paulo (e.g. SUGUIO \& MUSSA 1978; COIMBRA et al. 1980; ATENCIO 1986).

No perfil integrado apresentado na Figura 13 situado entre a Rua do Gasômetro e Avenida Rangel Pestana no Brás, pode-se observar algumas das características mencionadas anteriormente.

Embora os trabalhos atuais considerem a Formação Itaquaquecetuba mais jovem que a Formação São Paulo (RICCOMINI 1989; RICCOMINI \& COIMBRA 1992; RICCOMINI et al. 1992; ARAI \& YAMAMOTO 1995), a posição estratigráfica da Formação Itaquaquecetuba representa ainda assunto polêmico (MELO et al. 1989b), pois as relações estratigráficas com outras unidades não foram observadas em campo, dificultadas principalmente, pela sua forma de ocorrência restrita, em cotas abaixo de $710 \mathrm{~m}$.

Alguns aspectos levantados por RICCOMINI (1989), ressaltados por TAKIYA (1991) corroboram a hipótese que aponta a Formação Itaquaquecetuba como mais jovem que as outras unidades presentes na bacia: a Formação Itaquaquecetuba está relacionada a atividades tectônicas sin e pós-sedimentares (SUGUIO \& TAKAHASHI 1970; SUGUIO 1971; SUGUIO et al. 1971; 


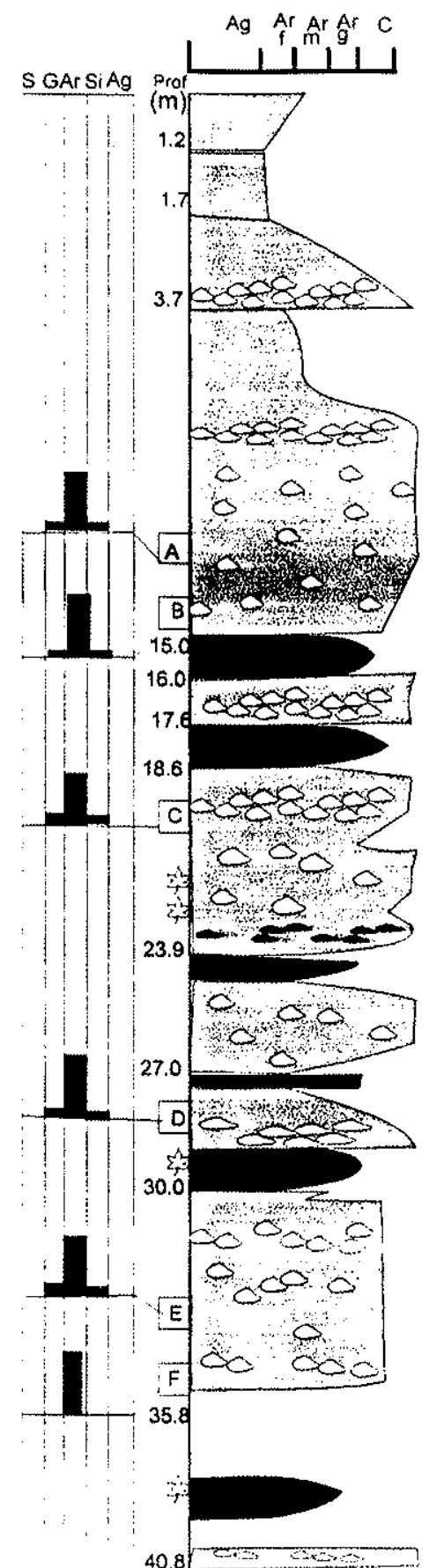

Local com coleta de amostras para análise palinológica
Solo areno argiloso marrom

Argila marrom

Areia fina a areia grossa e conglomerado constituído predominantemente por quartzo, e secundariamente por mica e turmalina

Areia muito fina argilosa passando a areia grossa alaranjada, com grãos subarredondados de quartzo, bem selecionados, seguida por conglomerado esbranquiçado, medianamente selecionado, com grãos subarredondados a subangulares. Este pacote apresenta quartzo predominantemente, mica e turmalina.

Lamito cinza esverdeado com grãos $2 \mathrm{~mm}$ de quartzo

Conglomerado esbranquiçado, pouca matriz argilosa

Lamito, semelhante ao anterior

Conglomerado arenoso, mal sclecionado, esbranquiçado, cot

areia grossa a fina. No intervalo de 22,2 a 23,5 notou-se lentes de argila com sulfetos (marcassita)

Lamito passando a lamito arenoso

Areia fina a grossa passando a conglomerado com matriz argilosa, com grãos de quartzo e feldspato:

Lamito cinza

Areia seixosa cinza esverdeada, com seixos de até $3 \mathrm{~cm}$

Lamito cinza esverdeado

Areia fina cinza

Areia fina a grossa mal selecionada

Lamito com grãos de quartzo e mica, areia seixosa na base

Areia conglomerática

Perfil da sondagem 12, CEPAS, Ráia Olímpica, Cidade Universitária, USP. Análise granulométrica nos intervalos $A, B, C, D, E$ e F. ( $S=\%$ seixos; $G=\%$ grânulos; $A r=\%$ areia; $\mathrm{Si}=\%$ silte; $\mathrm{Ag}=\%$ argila).

$$
\begin{array}{llllll}
A- & S=0 ; & \mathrm{S}=12.4 ; & \mathrm{Ar}=82,0 ; & \mathrm{Si}=4.5 ; & \wedge \mathrm{g}=1.1 \\
\mathrm{~B}- & \mathrm{S}=0 ; & \mathrm{G}=6.0 ; & \mathrm{Ar}=90.9 ; & \mathrm{Si}=2.4 ; & \wedge \mathrm{g}=0.7 \\
\mathrm{C} \cdot & \mathrm{S}=0 ; & \mathrm{G}=16.6 ; & \mathrm{Ar}=75.4 ; & \mathrm{Si}=4.8: & \mathrm{Ag}=3.2 \\
D- & \mathrm{S}=0 ; & \mathrm{G}=4.7 ; & \mathrm{Ar}=87,6 ; & \mathrm{Si}=5.8 ; & \mathrm{Ag}=1,9 \\
\mathrm{E}- & \mathrm{S}=0 ; & \mathrm{G}=11.7 ; & \mathrm{Ar}=80.6 ; & \mathrm{Si}=6,1 ; & \wedge \mathrm{g}=1.6 \\
\mathrm{~F}- & \mathrm{S}=0 ; & \mathrm{G}=4.6 ; & \mathrm{Ar}=88.1 ; & \mathrm{Si}=5.1: & \mathrm{Ag}=2.2
\end{array}
$$

Figura 12 - Descrição de sedimentos da Formação Itaquaquecetuba (TAKIYA 1991, com modificações) 
COIMBRA et al. 1983; ALMEIDA et al. 1984; RICCOMINI 1989; RICCOMINI \& COIMBRA 1992); seus sedimentos ocorrem em cotas inferiores a $710 \mathrm{~m}$, em contato direto com o embasamento da bacia (COIMBRA et al. 1983; ALMEIDA et al. 1984; RICCOMINI 1989); os niveis argilosos datados por palinologia podem corresponder a extraclastos de unidades mais antigas pertencentes a depósitos de meandros abandonados da Formação São Paulo (RICCOMINI 1989; RICCOMINI \& COIMBRA 1992), ou originados em turfeiras (ARAI 1986); os troncos vegetais da Formação Itaquaquecetuba indicam que suas camadas não sofreram soterramento muito maior que o constatado atualmente (ARAI 1986), revelando alguns gêneros ainda viventes em florestas tropicais (SUGUIO \& MUSSA 1978).

As análises palinológicas efetuadas em amostras coletadas na sondagem executada na Ráia Olímpica da USP (Figura 12) mostram que as amostras analisadas são geralmente "pobres" no que diz respeito a variedade de grupos polínicos, sendo observado ainda, a falta de espécies-guias nas mesmas. A amostra mais rica analisada, situada a $30,15 \mathrm{~m}$, apontou presença de Podocarpidites, Quadraplanus e U. Krempii, além da presença de esporo de fungo Punctodiporites harrisii, espécie considerada como guia do Oligoceno, embora já verificada no Eomioceno (ARAI, informação pessoal). A presença de Quadraplanus identificada também por YAMAMOTO (1996) para microflora da Formação Itaquaquecetuba é apresentada com espécie-guia de idade eomiocênica. $\mathrm{Na}$ tabela 2 são apresentados os principais palinomorfos encontrados nas seções analisadas. 


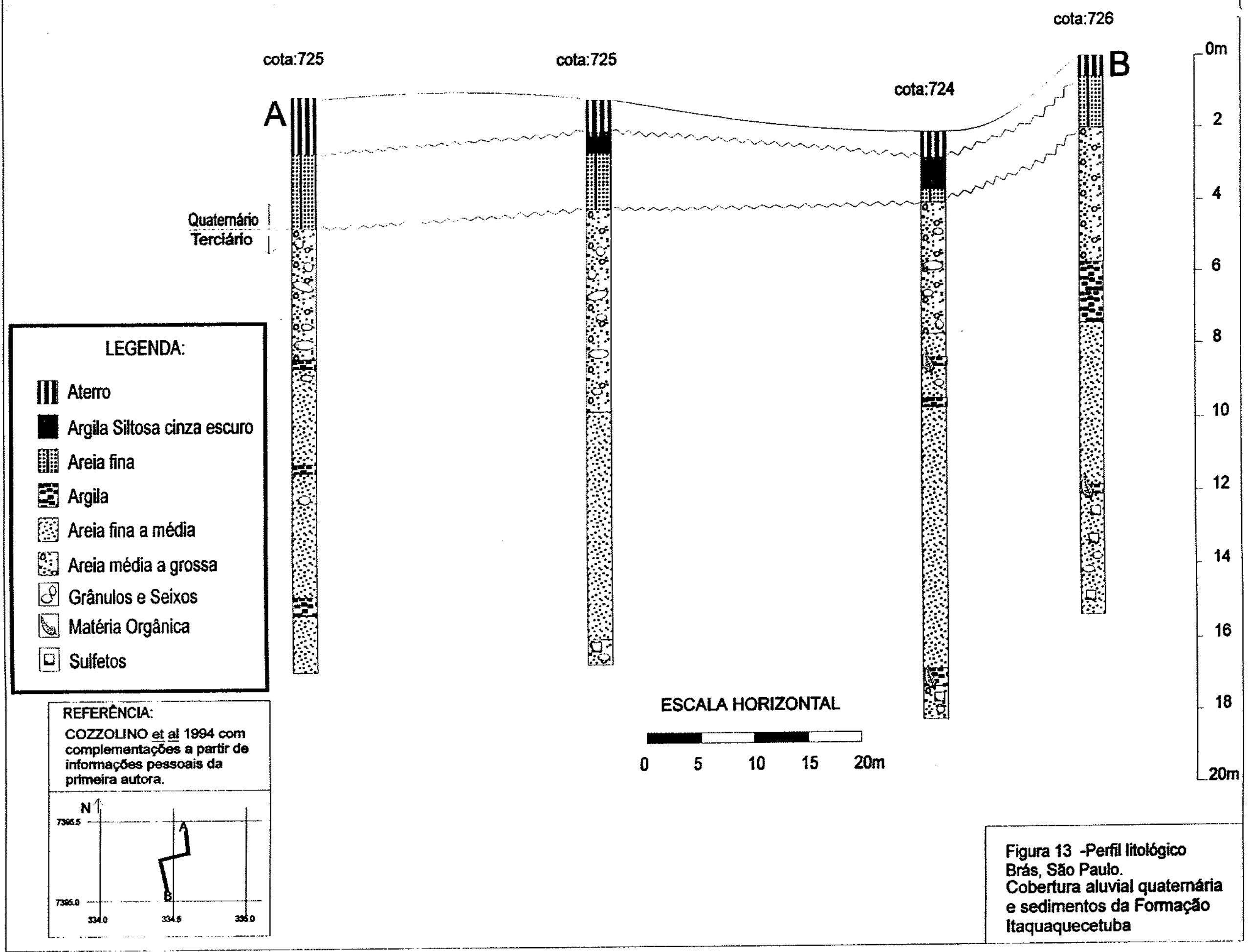


Tabela 2 - Principais Palinomorfos nas amostras de sondagem na Ráia Olímpica, USP.

\begin{tabular}{|l|l|l|l|l|l|}
\hline & $18 \mathrm{~m}$ & $22,6 \mathrm{~m}$ & $23,5 \mathrm{~m}$ & $30,15 \mathrm{~m}$ & $37,9 \mathrm{~m}$ \\
\hline Triletes lisos & & & & \\
\hline Reboulisporites fuegiensis & & & & & \\
\hline Cicalricosisporites & & & & & \\
\hline Foveotriletes & & & & & \\
\hline Laevigatosporites & & & & \\
\hline Verrucalosporites & & & & \\
\hline Azolla & & & & \\
\hline Salvinia & & & & \\
\hline Podocarpidites & & & & \\
\hline Proteacidites & & & & \\
\hline Ulmoideipites krempii & & & & \\
\hline Psilaperiporites & & & & \\
\hline Echiperiporites & & & & \\
\hline Perisyncolporites pokornvi & & & & \\
\hline Retitricolporites & & & & \\
\hline Psilatricolporites & & & & \\
\hline Quadraplanus & & & & \\
\hline Punctoporides harrisii & & & & \\
\hline Fusiformisporites polyedricus & & & & \\
\hline Fungos & & & & \\
\hline
\end{tabular}

\subsubsection{CARACTERÍSTICAS GEOTÉCNICAS}

Os depósitos sedimentares da Bacia de São Paulo apresentam características geotécnicas distintas devido, principalmente, à sua gênese que lhes confere uma variedade de litotipos presentes nas diferentes unidades litoestratigráficas, as quais apresentam geometria espacial e forma de ocorrência (homogeneidade dos pacotes sedimentares) diferenciada. Devem ser ainda considerados o grau de alteração dos sedimentos, além dos condicionantes antrópicos ( condições de escoamento superficial, cortes nos taludes, etc.).

Utilizou-se o método expedito - $4^{\mathrm{a}}$. aproximação, do método Miniatura Compactado Tropical-MCT para classificação de solos tropicais, sendo os resultados apresentados na Tabela 3. 


\begin{tabular}{|c|c|c|c|c|c|c|c|c|}
\hline \multicolumn{4}{|c|}{ COMPORTAMENTO LATERÍTICO } & \multicolumn{5}{|c|}{$\begin{array}{l}\text { COMPORTAMENTO } \\
\text { NÃO-LATERÍTICO }\end{array}$} \\
\hline & LG' & LA'-LG' & $\mathbf{L A}^{\prime}$ & NG' & NS'/NA' & NA'NS' & $\begin{array}{c}\text { NA'/ } \\
\text { NG'-NS' }\end{array}$ & NS'-NG' \\
\hline $\mathbf{A}$ & $\mathrm{H}-\mathrm{CO}-1$ & $\mathrm{H}-\mathrm{CO}-5 \mathrm{~A}$ & H-AL-3 & $\mathrm{H}-\mathrm{CO}-13$ & $\mathrm{H}-\mathrm{CO}-15$ & H-BSP-10 & TR-BR-2.5 & H-EMB-3 \\
\hline $\mathbf{M}$ & $\mathrm{H}-\mathrm{CO}-2$ & $\mathrm{H}-\mathrm{CO}-9$ & & H-BSP-9 & H-EMB-1 & & $\mathrm{H}-\mathrm{CO}-29$ & H-EMB5 \\
\hline O & $\mathrm{H}-\mathrm{CO}-3$ & $\mathrm{H}-\mathrm{CO}-11$ & & H-BSP 12 & H-EMB-4 & & $\mathrm{H}-\mathrm{SO}-4$ & H-EMB9 \\
\hline $\mathbf{S}$ & $\mathrm{H}-\mathrm{CO}-4$ & H-CO- 12 & & H-BSP14 & & & & H-BEM8 \\
\hline $\mathbf{T}$ & $\mathrm{H}-\mathrm{CO}-5$ & H-AL-12 & & & & & & \\
\hline $\mathbf{R}$ & $\mathrm{H}-\mathrm{CO}-13$ & H-AL-15 & & & & & & \\
\hline $\mathbf{A}$ & $\mathrm{H}-\mathrm{CO}-18$ & H-BSP-6 & & & & & & \\
\hline $\mathbf{S}$ & $\mathrm{H}-\mathrm{CO}-21$ & $\mathrm{H}-\mathrm{CO}-20$ & & & & & & \\
\hline & $\mathrm{H}-\mathrm{CO}-22$ & & & & & & & \\
\hline & $\mathrm{H}-\mathrm{CO}-24$ & & & & & & & \\
\hline & $\mathrm{H}-\mathrm{CO}-26$ & & & & & & & \\
\hline & $\mathrm{H}-\mathrm{CO}-27$ & & & & & & & \\
\hline & $\mathrm{H}-\mathrm{CO}-28$ & & & & & & & \\
\hline & PIQ-8.7 & & & & & & & \\
\hline & H-BSP-1 & & & & & & & \\
\hline & H-BSP-3 & & & & & & & \\
\hline
\end{tabular}

Tabela 3 - Resultado dos ensaios MCT

$\mathrm{H}-\mathrm{CO}$ - amostras de colúvio

H-AL - amostras de sedimentos aluviais

H-BSP- amostras de sedimentos terciários da Bacia de São Paulo

HEEMB - amostras de solo saprolitico de rochas do embasamento

TR/ PIQ- amostras de sondagem em sedimentos terciários da Bacia de São Paulo

H-SO - amostra de solo de alteração de colúvio

A classificação $\mathrm{MCT}$ pelo método expedito realizada em lamitos coletados em três localidades distintas, à Av. Teotônio Vilela, Capela do Socorro (H-BSP-1); à Av. Arq. Vilanova Artigas, Zona Leste (H-BSP-3) e à R. Dr. Fonseca Brasil (H-BSP-6), enquadraram-se no grupo LG' para as três amostras, confirmando seu comportamento favorável quanto a capacidade de suporte, expansão, proteção a erosão, e revestimento primário.

Deve-se salientar que a classificação MCT relaciona-se ao comportamento dos solos compactados. Dessa forma, os comportamentos descritos anteriormente seriam válidos, a rigor, apenas para o material compactado. Entretanto verifica-se em campo uma provável correspondência entre $\mathrm{o}$ aspecto " baixa susceptibilidade à erosão", dos sedimentos predominantemente argilosos da Formação Resende ocorrentes em taludes de corte com condições de escoamento superficial favoráveis, e a classificação geotécnica "comportamento laterítico -LG" 
De fato, nos taludes executados nos sedimentos lamiticos com matriz argilosa abundante e grânulos de quartzo, à Av. Teotônio Vilela, Capela do Socorro, Zona Sul, não foram verificadas feições erosivas, mostrando que mesmo in situ, o lamito apresenta baixa suceptibilidade à erosão.

Deve-se lembrar no entanto que esses sedimentos nem sempre apresentam características favoráveis segundo a classificação MCT. A amostra TR-BR2.5 coletada a $2.5 \mathrm{~m}$ de profundidade através de sondagem, apresentou comportamento não lateritico (NA'/ NG'-NS'). Os difratogramas efetuados nessa mesma amostra apontou a presença de mica que pode ter influenciado no resultado, uma vez que o argilomineral encontrado, a caulinita, apresenta comportamento plástico, não expansivo.

A alta resistência dos sedimentos (índices elevados de Standart Penetration Test - SPT) pode ser citada como uma outra característica favorável do ponto de vista geotécnico, dos sedimentos da Formação Resende, os quais foram anteriormente descritos como "argilas duras", cinza esverdeadas a cinza avermelhadas (COZZOLINO 1972 e 1980).

Um exemplo claro desta propriedade foi verificada na Av. Giovanni Gronchi, em obra para construção de edifício de alto padrão, onde, segundo o engenheiro responsável pela obra, foi necessário utilizar-se marteletes na abertura de poços para executar a fundação da obra, através de tubulões.

Os grupos da classificação MCT determinados pelo método expedito utilizado em sedimentos intemperizados da Formação São Paulo, em um perfil situado no entroncamento das ruas Capital Federal e Paris, na Lapa, apontaram comportamento não laterítico para argila roxa e a areia fina amarelada, classificadas respectivamente nas classses NG' e NA'.

Foram realizados ainda ensaios em sedimentos argilosos da Formação São Paulo, da fácies de planície de inundação, em com diferentes consistências. As amostras (H-BSP-12, H-BSP-14) foram coletadas em talude de corte, em obra para construção para um Conjunto Habitacional na Zona Leste (C. H. Garagem).

$O$ resultado dos ensaios foi o mesmo para as duas amostras, que apresentaram comportamento não laterítico (NG'). Seria esperado para a amostra H-BSP-12, coletada em solo de alteração argiloso avermelhado, comportamento mais favorável, laterítico. Esse resultado poderia ser explicado, no entanto, por não se tratar de material intensamente pedogeneizado (típicas argilas vermelhas porosas). 
Os resultados da classificação expedita MCT indicam que os depósitos analisados da Formação São Paulo não seriam recomendáveis, quando devidamente compactados, para uso em pavimentação (revestimento primário, base de pavimento, reforço do subleito, subleito compactado), em aterro compactado, e mesmo como camada de proteção à erosão.

Já em termos de fundação, as argilas da Formação São Paulo, devida sua elevada capacidade de suporte, permitem opções e fundações direta, de forma segura e econômica (DÉCOURT 1992).

Este fato pode ser comprovado na Praça Charles Müller, no Pacaembu, onde verificou-se uma antiga galeria de águas pluviais assentada diretamente sobre argilas arroxeadas de planície de inundação da Formação São Paulo (Fotografia 20).

A ocorrência de intercalações de camadas de areia e argila em sub-superfície pode representar situações não favoráveis do ponto de vista da geologia de engenharia, principalmente no que diz respeito a execução de obras com fundações profundas, uma vez que os solos podem apresentar compacidade mais baixa que no geral nessas zonas (VARGAS 1953).

Situações de intercalações de camadas com diferentes granulometria (argila a grânulos) são observadas com mais freqüência nos sedimentos fluviais meandrantes da Formação São Paulo. Entretanto, essas ocorrências "erráticas" de camadas sedimentares são também verificadas na Formação Resende.

Esse quadro é verificado por exemplo, na área central do município, onde foram relatados por VARGAS (1953) problemas verificados em fundações de edifícios situados no centro da cidade, onde ocorrem sedimentos referiveis aos da Formação Resende.

Menciona-se ainda experiência da Companhia do Metropolitano de São Paulo - METRO na execução de obras enterradas e subterrâneas há mais de 20 anos, nas quais têm sido utilizados nesses últimos anos, os conhecimentos da estratigrafia e tectônica da Bacia de São Paulo, mostrando a importância da aplicação dos mesmos nessa área da engenharia (ROCHA \& CELESTINO 1992). 


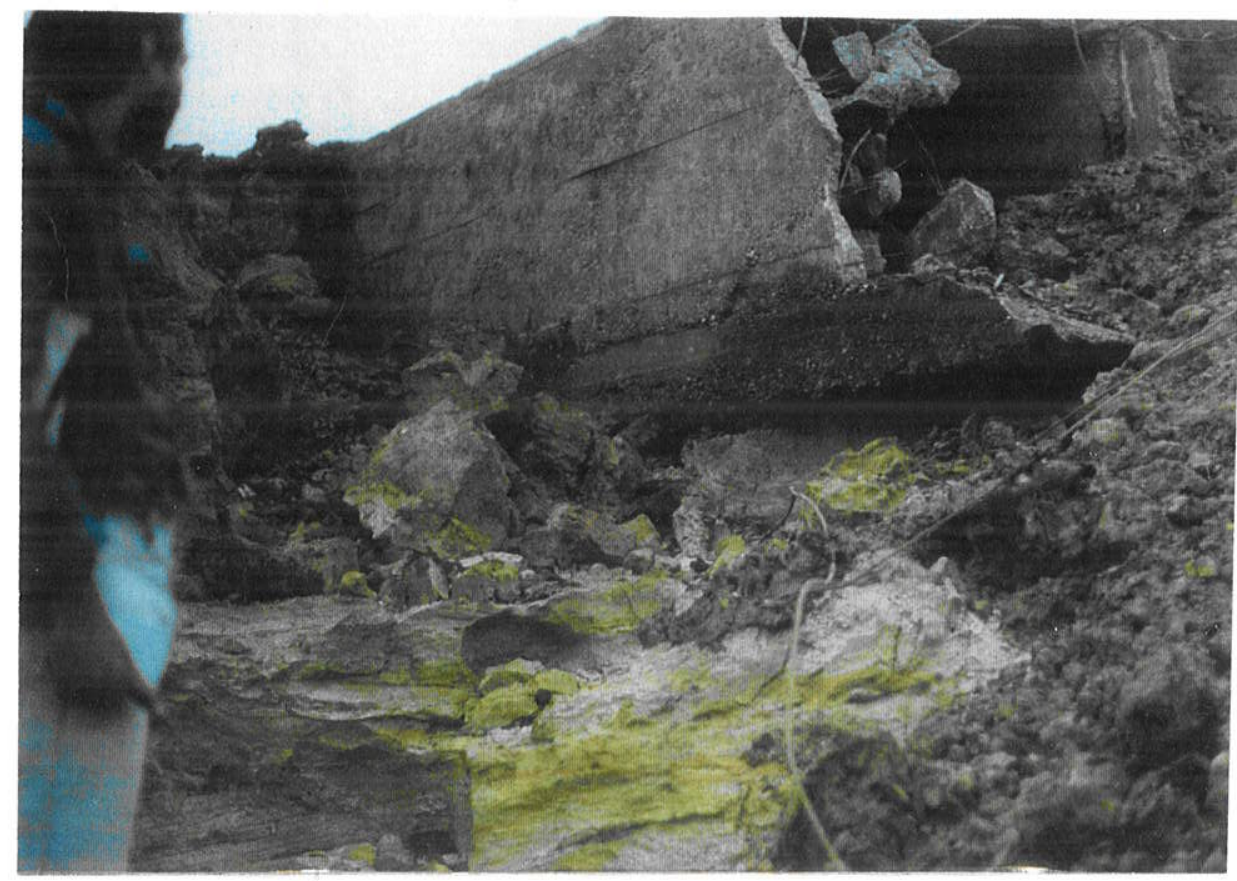

Fotografia 20 - Galeria de águas pluviais sobre sedimentos da Formação São Paulo. Praça Charles Müller, Pacaembu.

No trabaiho citado os autores adotam as unidades litoestratigráficas propostas por RICCOMINI (1989) distinguindo comportamento geotécnico dos depósitos das Formações São Paulo e Resende. ROCHA \& CELESTINO (1992) consideram em geral, os sedimentos da Formação São Paulo como mais argilosos que aqueles da Formação Resende, apontando também diferenças entre as areias presentes nas duas unidades, como o maior grau de intemperismo e distribuição das camadas mais errática, da primeira em relação a segunda unidade.

As argilas lacustres da Formação Tremembé não foram classificadas segundo método MCT expedito devido sua ocorrência restrita (Anexo A). Em termos de comportamento geotécnico em obras subterrâneas acredita-se que esses depósitos apresentem características semelhantes às das argilas das Formações São Paulo.

Os depósitos predominantemente areno-conglomeráticos da Formação Itaquaquecetuba exibem também ocorrência localizada. São observados como mencionado anteriormente, sob os atuais aluviões de algumas das principais drenagens do Municipio e na região de Itaquaquecetuba (Anexo A). 
Do ponto de vista da engenharia de túneis as camadas representam ainda um desafio a ser enfrentado através da intensificação das investigações em sub-superficie e adoção de medidas inovadoras (COZZOLINO et al. 1994). A ocorrência de falhamentos associados a unidade representa um outro elemento crítico nas obras em sub-superficie. 


\section{CAPÍTUlO 5}

\section{COBERTURAS QUATERNÁRIAS}

\subsection{INTRODUÇ̃̃O}

Apesar dos importantes trabalhos já realizados por diversos autores na área em enfoque e arredores (e.g. ALMEIDA et al. 1984; MELO et al. 1987; TURCQ \& MELO 1989; RICCOMINI et al. 1989) os depósitos quaternários carecem ainda de estudos de detalhe que melhor os caracterize com relação aos locais de ocorrência, extensão e espessura desses corpos, litologias presentes, idades absolutas, conteúdo polínico, que levaria a inferências paleoclimáticas, comportamento geotécnico, etc.

Do ponto de vista da geologia urbana a caracterização desses depósitos superficiais refletese fundamentalmente na melhor compreensão tecnológica dos mesmos. Problemas referentes ao uso e ocupação do solo urbano relacionados principalmente aos escorregamentos (áreas de risco), obras de engenharia de magnitudes diversas que envolvam fundações rasas, são algumas das principais áreas onde esses conhecimentos devem ser aplicados no sentido da otimização de custos, no caso de obras de engenharia.

Serão abordados nesse item os depósitos aluviais e baixos terraços associados às drenagens atuais, nos quais foram executadas análises palinológicas, MCT, datações radiocarbono, difratometria de Raios X e Microscopia Eletrônica de Varredura.

Os colúvios encontrados neste estudo, sua caracterização e seu comportamento geotécnico, serão também aqui apresentados e discutidos, considerando-se ainda algumas datações realizadas em fragmentos de carvão encontrados no topo desses depósitos.

Mencionar-se-á neste item ainda, a depressão circular de Colônia, localizada em Parelheiros, na Zona Sul de São Paulo, considerado importante sítio deposicional, pois certamente guarda em seu registro sedimentar, informações acerca de variações paleoclimáticas ocorridas principalmente durante o Quaternário, no Município de São Paulo e arredores. 


\subsection{DEPÓSITOS DE COLÚVIO}

\subsubsection{ASPECTOS GERAIS}

São denominados depósitos coluviais o conjunto representado por stone line e horizonte argiloso ou arenoso situado geralmente acima desta feição, podendo, esta última, estar ausente nos depósitos coluviais, dependendo da área fonte e dos processos intempéricos e pedogenéticos a eles associados.

Os colúvios são depósitos transportados (PLAISANCE \& CAILLEUX 1958) relacionados ao desenvolvimento de encostas, podendo em alguns casos, onde o perfil de alteração é suficientemente conhecido, apresentar significados paleoclimáticos e morfogenéticos. São depósitos porosos exibindo baixas compacidade e consistência, designados também na geologia de engenharia como solos colapsiveis ( GIACHETI et al. 1993).

Segundo BIGARELLA \& MOUSINHO (1965) os colúvios revestem normalmente a topografia, recobrindo terraços, sendo que nas várzeas de inundação atuais a separação destes dos depósitos aluviais é muitas vezes difícil, sendo ambas as feições consideradas como um único conjunto, a "várzea".

Merecem citação os trabalhos pioneiros de MOUSINHO \& BIGARELLA 1965; BIGARELLA \& MOUSINHO 1965; AB'SABER 1969 a,b) que apresentaram grande contribuição ao estudo desses depósitos, destacando principalmente, aspectos da evolução morfogenética dos relevos estudados.

O termo stone line é aqui empregado para designar concentrações de seixos e fragmentos líticos apresentando diferentes graus de laterização. Sabe-se entretanto, que esses depósitos devem ser vișualizados na forma tridimensional, pois referem-se na realidade, a uma superficie, pavimento ou tapete (AB'SABER 1969b), que apresentam na literatura diversas designações como cascalhos inhumados, linha de seixos e fragmentos, linhas de pedra, chão pedregoso, etc. (AB' SABER 1962, 1969 a,b; MOUSINHO \& BIGARELLA 1965)

Em relação a gyênese das stone lines, duas hipóteses principais expressam as tendências atualmente existentes defendidas por diversos autores: a aloctonista, mais antiga e a autoctonista, mais recente (LECOMTE 1988). 
Segundo a hipótese aloctonista, as stone lines seriam formadas pela perda da fração fina do solo por lixiviação, e conseqüente acúmulo de fragmentos líticos, seguido de recobrimento por processos sedimentares fluviais, eólicos, lacustrinos, ou de movimento de massas. Já a versão autoctonista (in situ) relaciona a origem das stone lines a movimentos descendentes de fragmentos líticos devido a processos de lixiviação, bioturbação, pedoturbação, etc.

Deve-se mencionar ainda a hipótese que envolve processos biológicos, que sugere que as stone lines sejam formadas por movimentos acendentes (BOULET et al. 1995)

Independentemente da hipótese defendida em relação a gênese dos stone lines verifica-se que a maioria dos autores advogam a presença de clima mais seco que o atual para a formação desses depósitos (AB'SABER 1969; MOUSINHO \& BIGARELLA 1965; BIGARELLA \& MOUSINHO 1965; RODRIGUEZ 1994). Segundo esse último autor a presença de fragmentos lateríticos poderia representar restos de encouraçamentos formados em climas mais secos que o atual, que posteriormente, em condições climáticas gradualmente mais úmidas, teriam sofrido retrabalhamento geoquímico acarretando na fragmentação da couraça laterítica e migração, por diferença de densidade ou por sucessivos recobrimentos desses fragmentos para o horizonte inferior, concentrando-se na forma de stone-lines.

\subsubsection{DEPÓSITOS DE COLÚVIO PRESENTES NA ÁREA DE ESTUDO}

Embora pouco descritos na literatura, os depósitos de colúvio são encontrados de maneira generalizada por toda a área estudada (Anexo A), sendo melhor caracterizados na Zona Sul do Município.

Os colúvios presentes na área de estudo apresentam pequenas espessuras, variando de 0.5 a $3 \mathrm{~m}$. Ao longo de uma mesma encosta nota-se pequena variação na espessura desses depósitos, os quais geralmente exibem camadas mais delgadas no topo, notando-se a partir da meia encosta para sua base, um tênue espessamento desses depósitos, podendo indicar até $3 \mathrm{~m}$ de espessura. No entanto as espessuras mais comuns observadas são aquelas entre 0,5 a 2,0 metros.

Revelam tons predominantemente amarronzados (bruno) e ocre, ou ainda colorações amareladas e avermeihadas (Figuras 14 e 15 e Fotografias 21 a 28). 
A maioria dos depósitos identificados apresentam stone line, mais ou menos desenvolvidas, que grosseiramente acompanham a topografia local.

As camadas coluviais observadas apresentam estrutura maciça e encontram-se geralmente afetados por estruturas de bioturbação (canalículos) e trincas de ressecamento (Fotografias 23 e 25).

Os depósitos de colúvio são mal selecionados com granulometria variando de silte a grânulos angulosos a subangulosos, constituídos em geral por grãos de quartzo e laterita, ocorrendo localmente seixos angulosos a subarredondados, de quartzo, quartzito e laterita na maioria das vezes, dispersos em matriz predominantemente argilosa.

Os clastos observados em seções delgadas correspondem essencialmente a grãos de quartzo de dimensões muito variadas, apresentando por vezes textura sacaróide, muscovita; ocorrendo na forma de pequenas ripas, geralmente na fração areia fina, além de fragmentos líticos, os quais exibem-se predominantemente alterados (Fotografias 29 a 37). Como minerais acessórios foram notados turmalina e titanita (Fotografia 38), além de grãos oxidados, na maioria das vezes não identificados, presentes no arcabouço (Fotografia 39), indicando de enriquecimento em $\mathrm{Fe} / \mathrm{Al}$ provavelmente relacionados a processos intempéricos.

O corante de coloração azul (alizarina) utilizado na confecção das lâminas destacou os poros desses depósitos, e conforme esperado, apontou altos índices de porosidade, variando de $10 \%$ a $25 \%$.

Os poros observados tem feições variadas, predominando as formas em finos filetes ou canalículos irregulares (Fotografias 29, 30, 34, 35), com aberturas (espessuras) chegando a $0.3 \mathrm{~mm}$. Ocorrem ainda poros com formas mais arredondadas ( Fotografia 30), geralmente conectados aos filetes, os quais por sua vez, encontram-se geralmente interligados (Fotografia 34). Em muitos casos verificou-se os poros em contato com grãos do arcabouço, por vezes bordejando os mesmos (Fotografia 29).

As características acima relacionadas, juntamente a outras feições, explicariam a grande susceptibilidade desses depósitos a escorregamentos. Quando secos as camadas podem oferecer aparente estabilidade, entretanto, a disposição e forma dos poros aliados a eventual presença de fraturamentos e feições de bioturbação, facilitaria a rápida saturação desses depósitos pouco 
espessos em contato com a água, aumentando a pressão neutra dos mesmos, causando por fim a sua ruptura.

Estudos realizados em escorregamentos associados a depósitos coluviais da Serra do Mar na região próxima às cidades de Cubatão e Santos (WOLLE 1989) apontam que a instabilização das encostas é provocada pela redução da resistência do solo. O solo insaturado segundo o autor citado, apresenta "coesão aparente", devido a pressão de sucção ( pressões neutras negativas) existente no mesmo. A ação das águas de chuva, em determinadas circunstâncias, produz o avanço, encosta adentro, de uma frente de saturação que "encharca" o solo provocando a diminuição de sua resistência, causando rupturas do tipo translacional, predominantente.

O autor mostra ainda que a superfície potencial de ruptura situa-se no contato colúvio/ camada subjacente, sendo essa última constituida na área, por solo saprolítico. Menciona-se ainda que a condição de condutibilidade hidráulica $(K)$ observada horizontes superficiais mapeados, aumenta com a profundidade devido a e existências de fendas e fraturas abertas no solo e rocha alterada.

As análises de difratogramas de Raios X e Microscopia de Varredura realizadas em amostra coletada em talude situado a meia encosta à Av. São Miguel, em obra para construção do Conjunto Habitacional Garagem, indicaram a caulinita como argilomineral predominante do depósito coluvial analisado.

As imagens obtidas através do MEV apontam caulinitas com formas placóides de pequena dimensão e bordas arredondadas a pouco angulosas (Fotografias 40 e 41) 


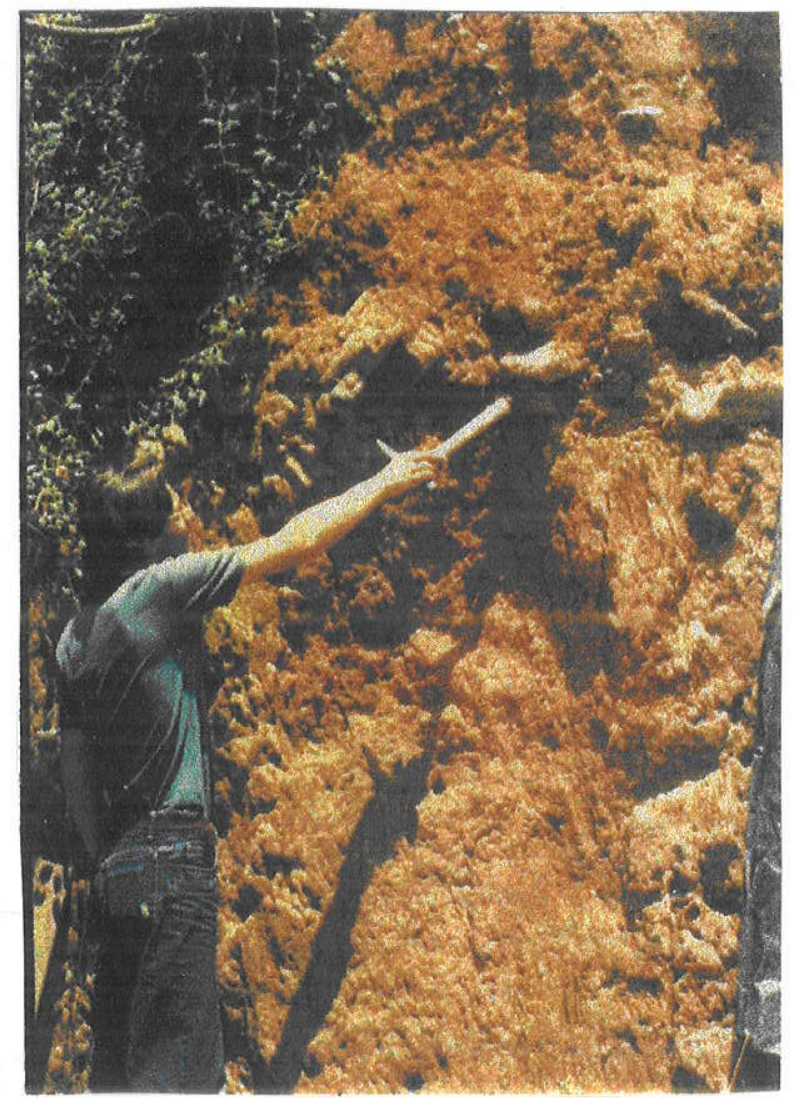

Fotografia 21 - Colúvio de coloração marrom, com matriz argilo-arenosa, apresentando, na base, stone line. Jardim Monte Azul, Campo Limpo.

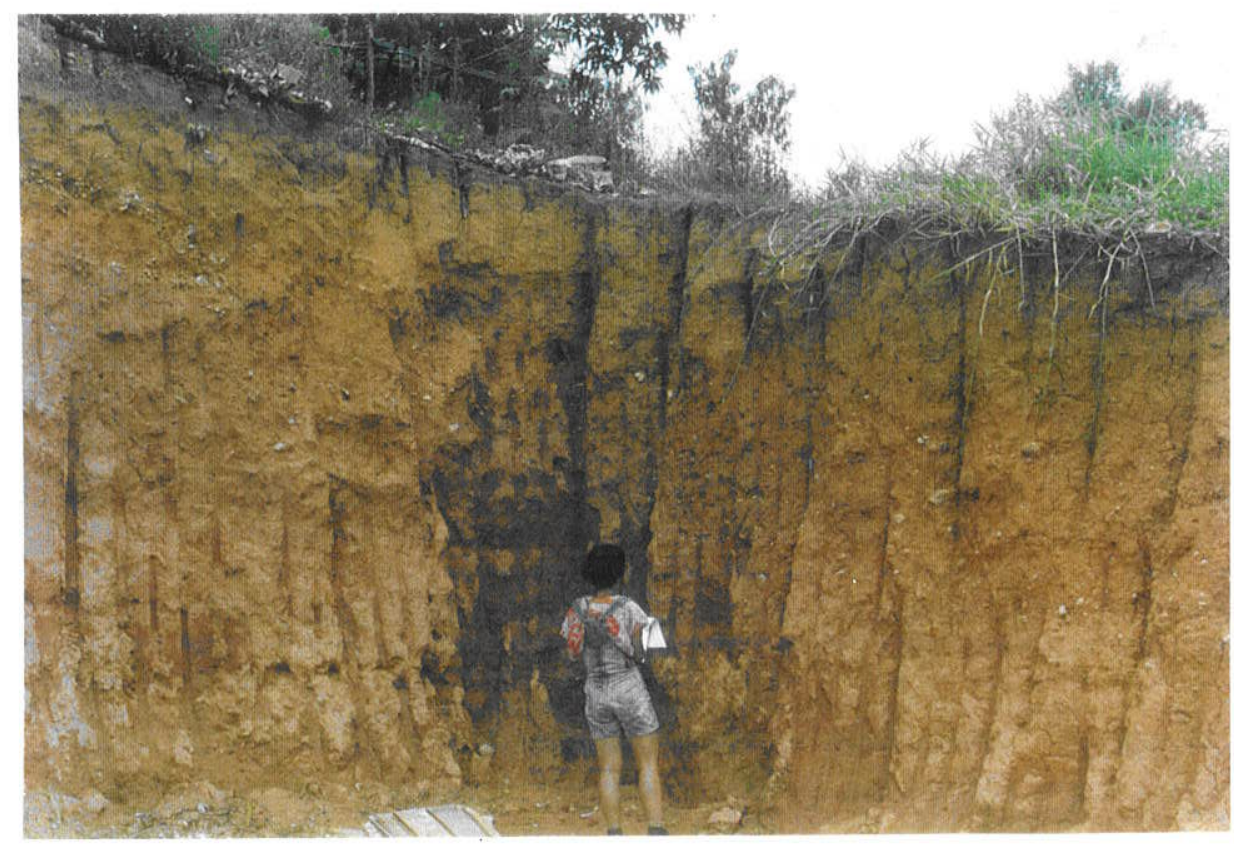

Fotografia 22 - Colúvio marrom-claro, com seixos dispersos na matriz argilo-arenosa, assentado sobre solo saprolítico de gnaisse. Rua dos Antípodas, Campo Limpo. 


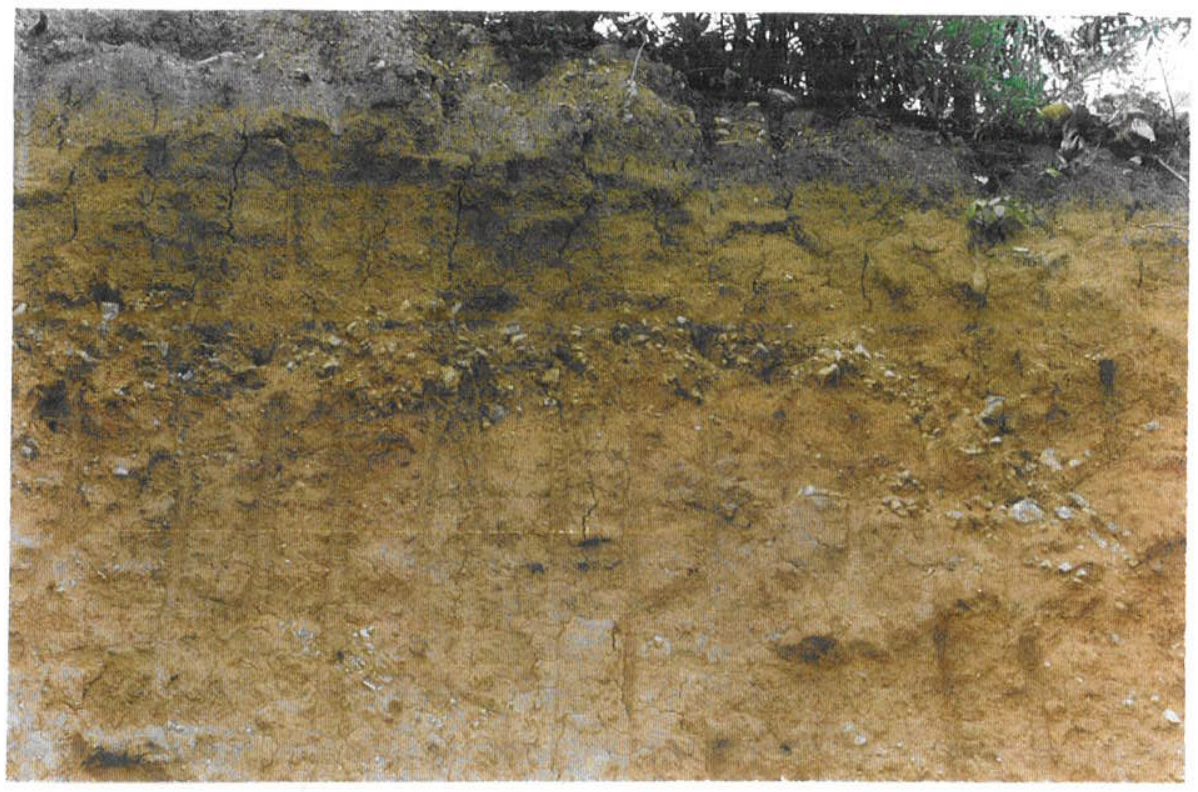

Fotografia 23 - Detalhe da foto anterior, destacando a presença de stone line na porção basal do depósito.

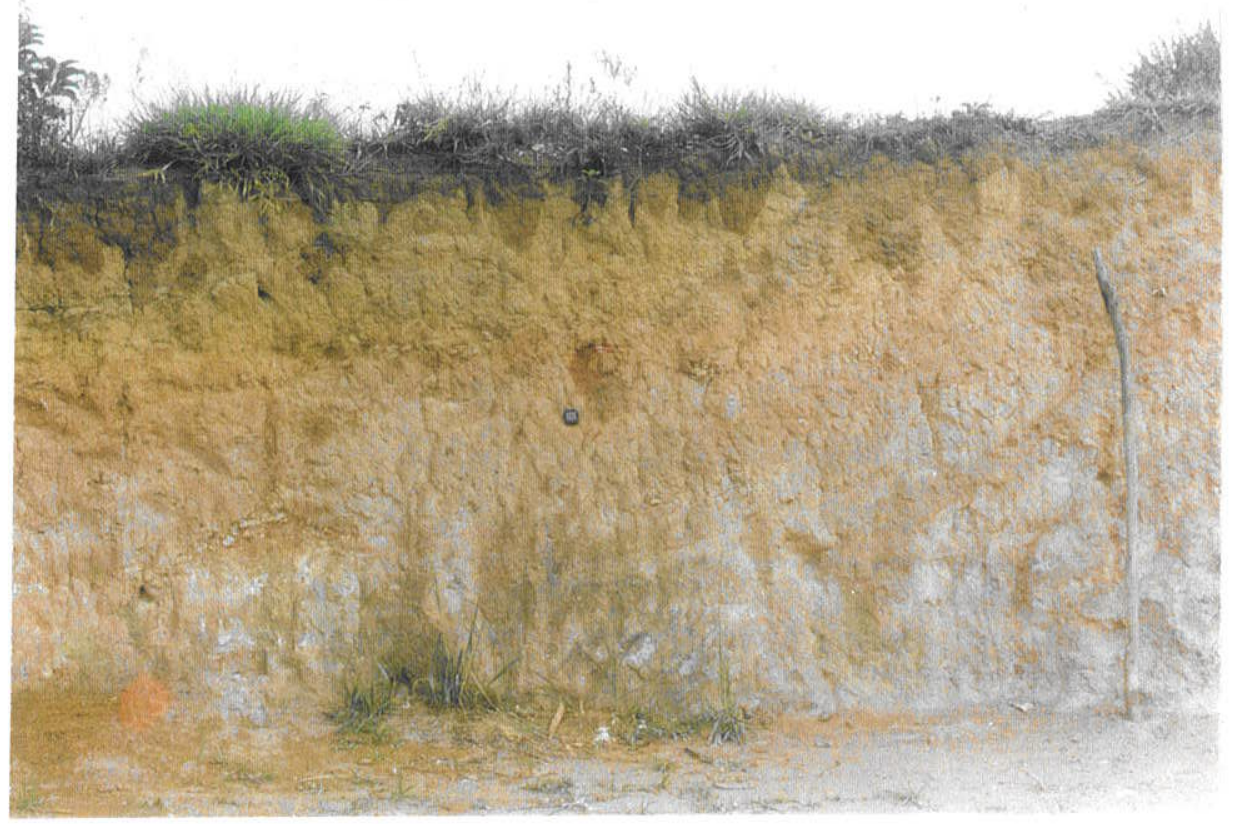

Fotografia 24 - Colúvio marrom-amarelado, com stone line na base. Rua Nova Tuparoquera, Campo Limpo. 


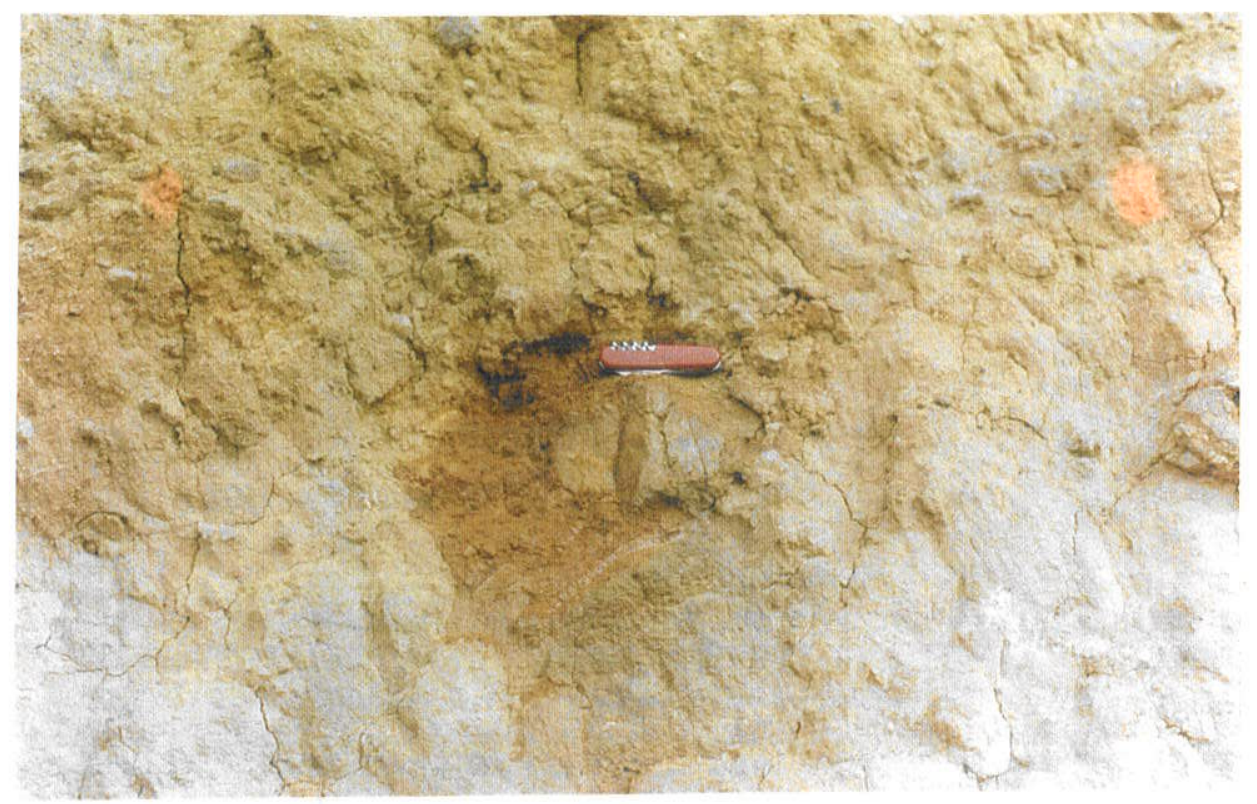

Fotografia 25 - Detalhe da foto anterior, destacando stone line constituído por seixos de fragmentos líticos laterizados.

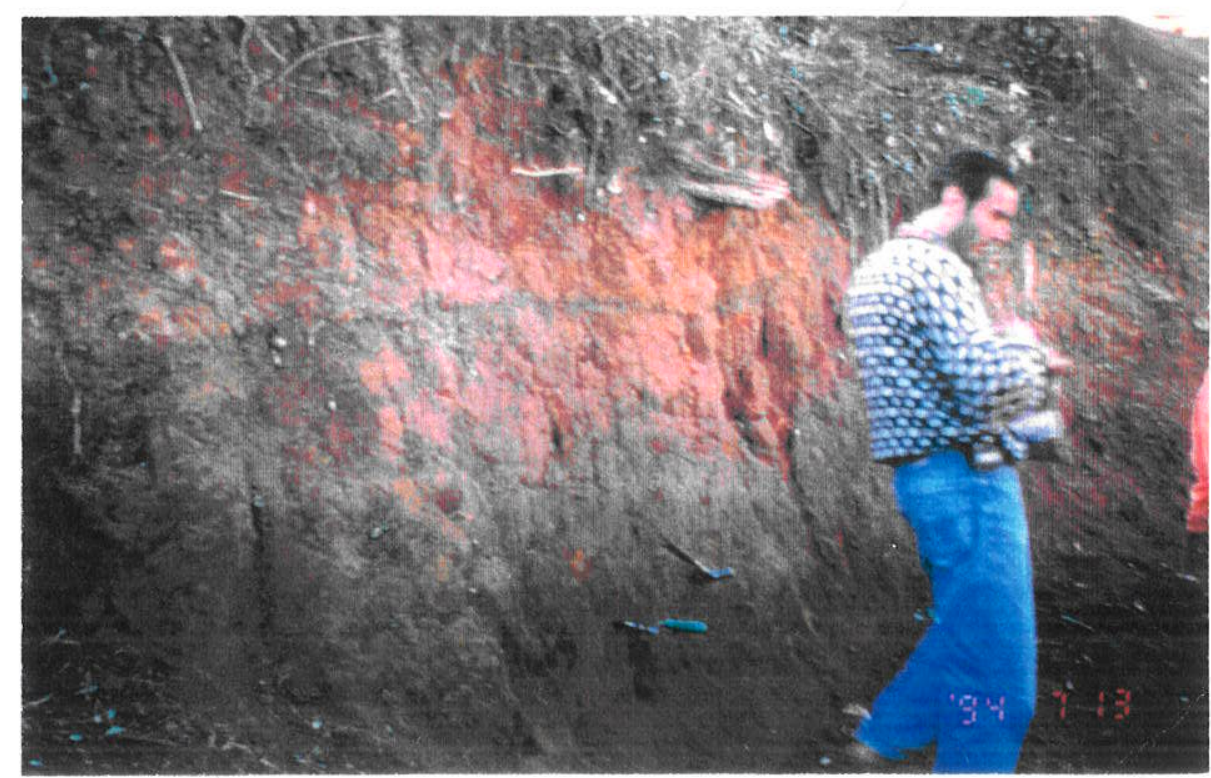

Fotografia 26 - Colúvio de coloração marrom-acastanhado, apresentando, no topo, fragmentos de carvão (área central da foto). Rua Eirunepê, Capela do Socorro. 


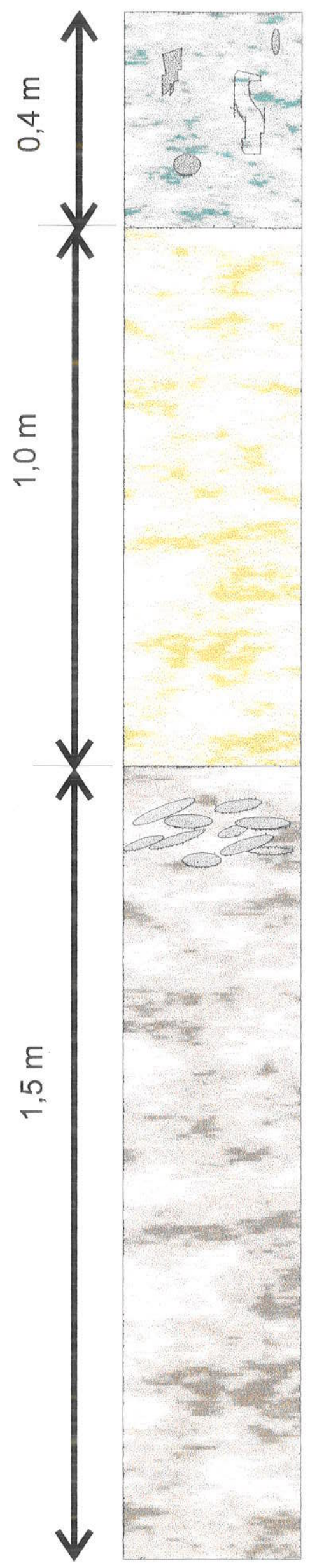

Aterro. Depósito tecnogênico, material argiloso. Presença de plásticos e fragmentos de madeira.

Material remobilizado (aterro ?), argilo-arenoso, marrom.

Nível contínuo de carvão, apresentando fragmentos de 1 a $10 \mathrm{~cm}$.

Colúvio poroso, argilo-arenoso, marrom escuro, apresentando grânulos de quartzo angulosos a subarredondados. São observados muitos fragmentos de carvão dispersos na matriz arenosa. Classificação MCT: LG'.

Figura 14 - Perfil litológico. Rua Eirunepê, Capela do Socorro. 


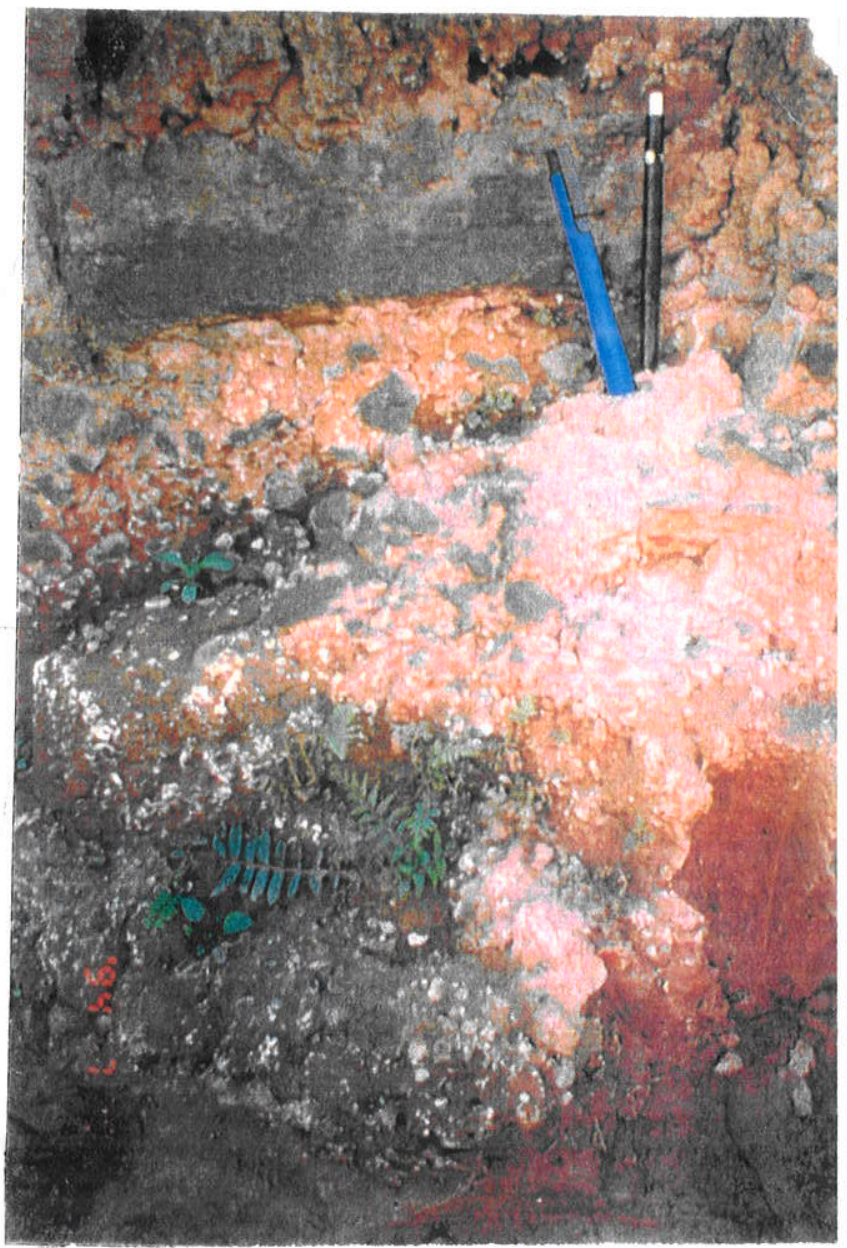

Fotografia 27 - Camada de colúvio marrom onde é destacado o stone line constituído por fragmentos líticos arredondados de laterita. Rua Miguel Lobo, Jardim Santo André, Zona Leste. 


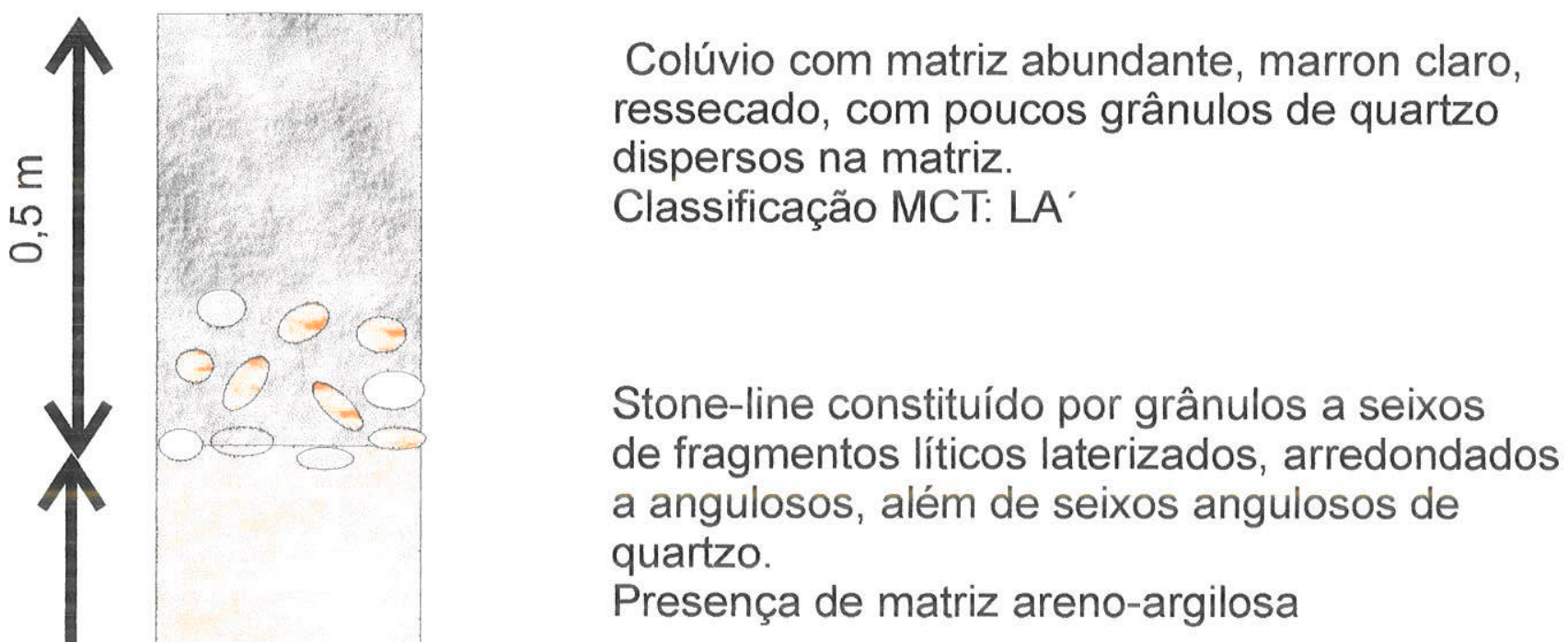

Solo saprolítico de xisto

Figura 15 - Perfil litológico. Rua Miguel Lobo, Zona Leste. 


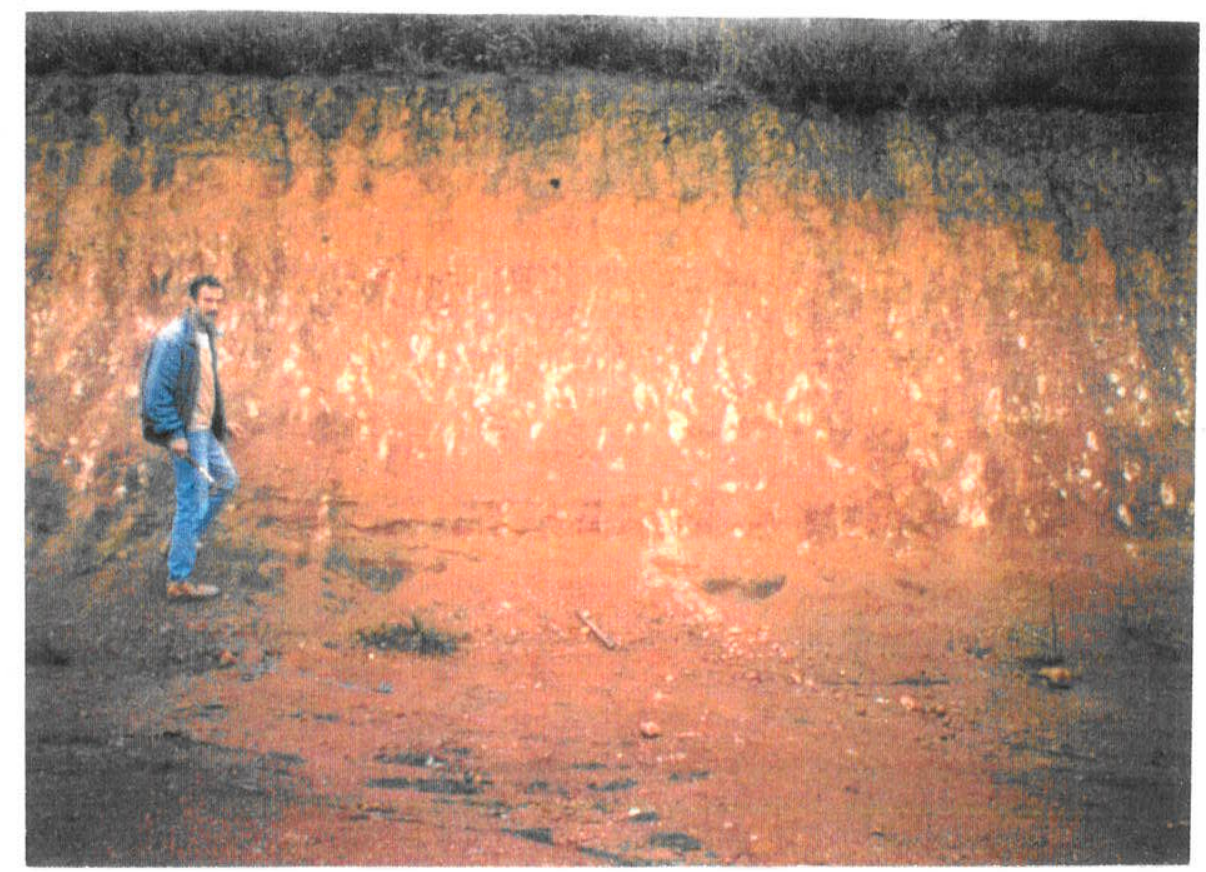

Fotografia 28. Colúvio de coloração marrom, assentado sobre sedimentos da Formação Resende. Rua Fonseca Brasil, Morumbi.

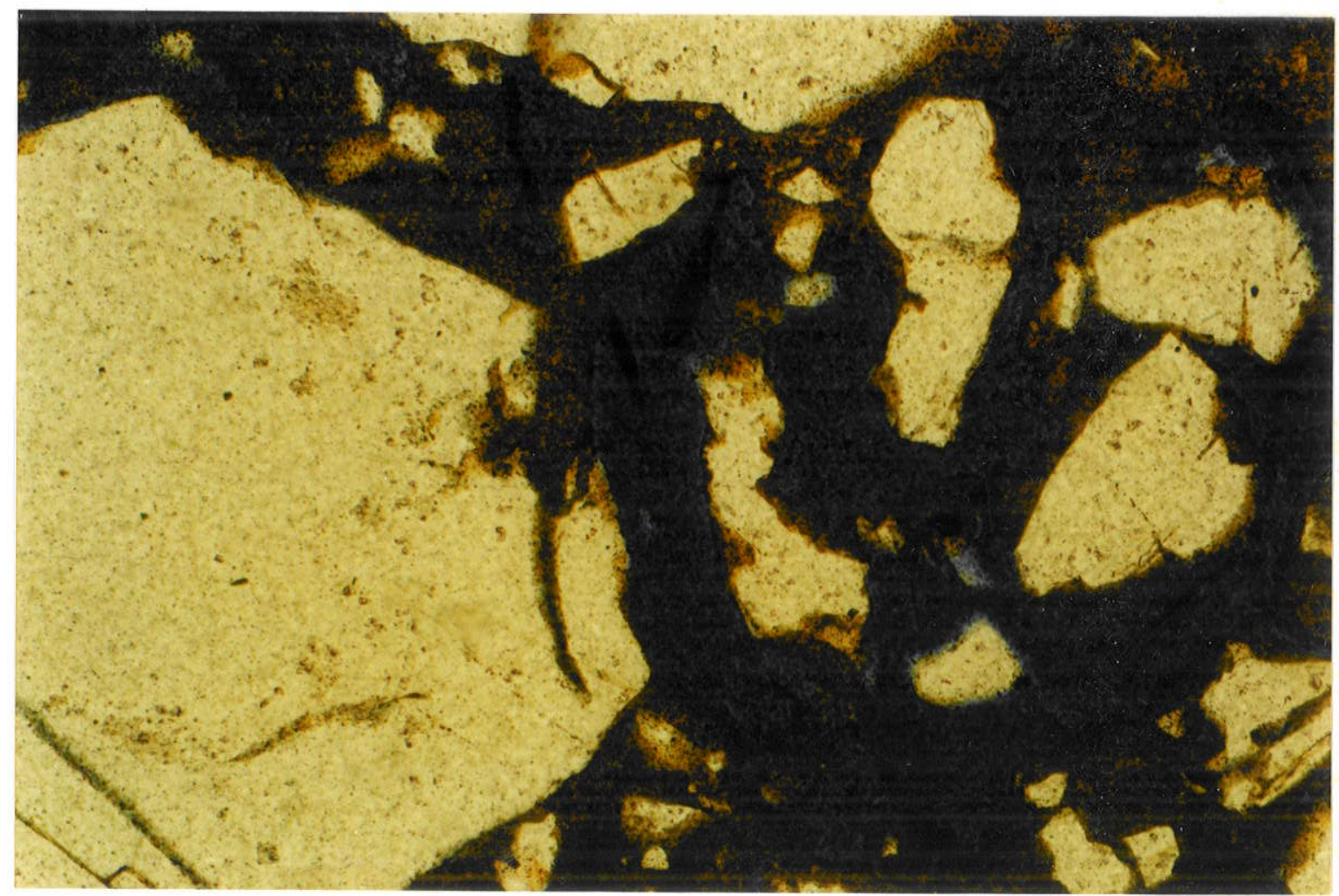

Fotografia 29. Grãos de quartzo angulosos, envoltos por poros (azul) e matriz argilosa. Amostra HCO-2. Jardim Paranapanema, Campo Limpo. Fotomicrografia. Nicóis paralelos. Aumento 2,5 X. 


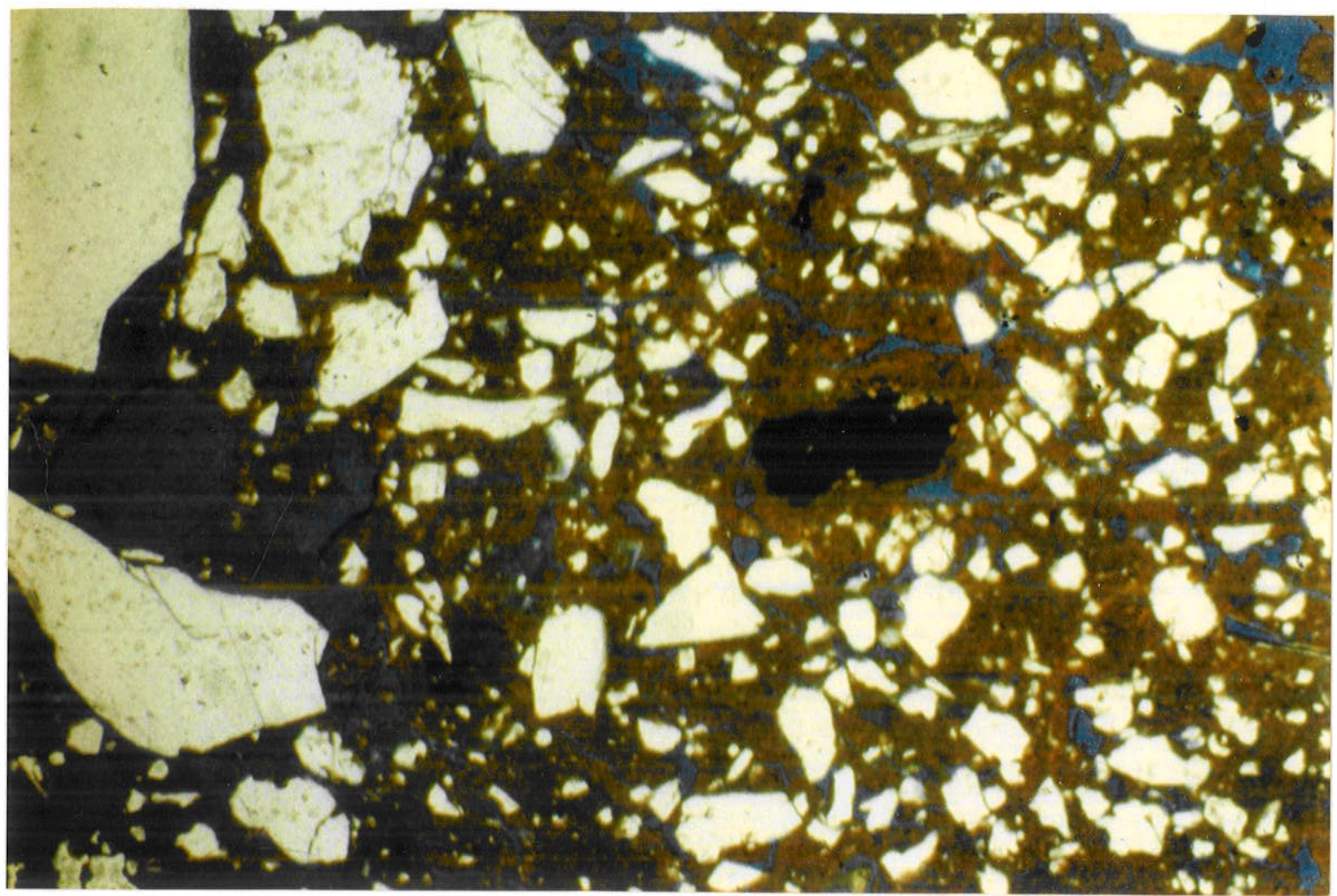

Fotografia 30. Grãos de quartzo de dimensões variadas sustentados por matriz argilosa. Notar presença de grão oxidado próximo ao centro da foto, e as formas em filetes e aproximadamente circular de poros, os quais apresentam interligações. Amostra H. CO-2. Jardim Paranapanema, Campo Limpo.

Fotomicrografia. Nicóis paralelos. Aumento 2,5 X.

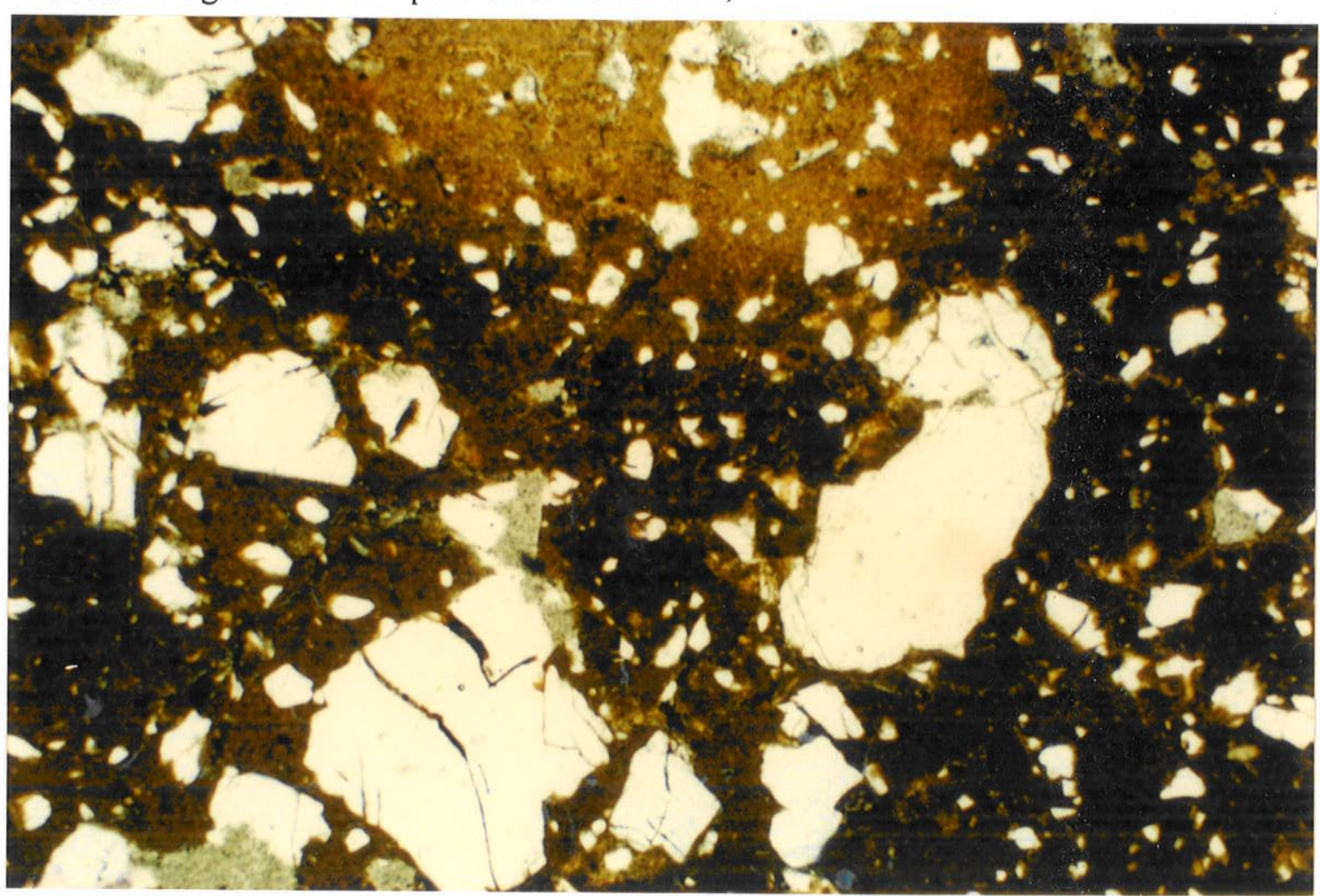

Fotografia 31. Grãos de quartzo angulosos a subangulares, dimensões variadas, sustentados por matriz argilosa. Notar a presença de pequenos poros, na parte inferior da foto. Amostra H-CO-5. Rua Nova Tuparoquera, Campo Limpo.

Fotomicrografia. Nicóis paralelos. Aumento 2,5 X. 


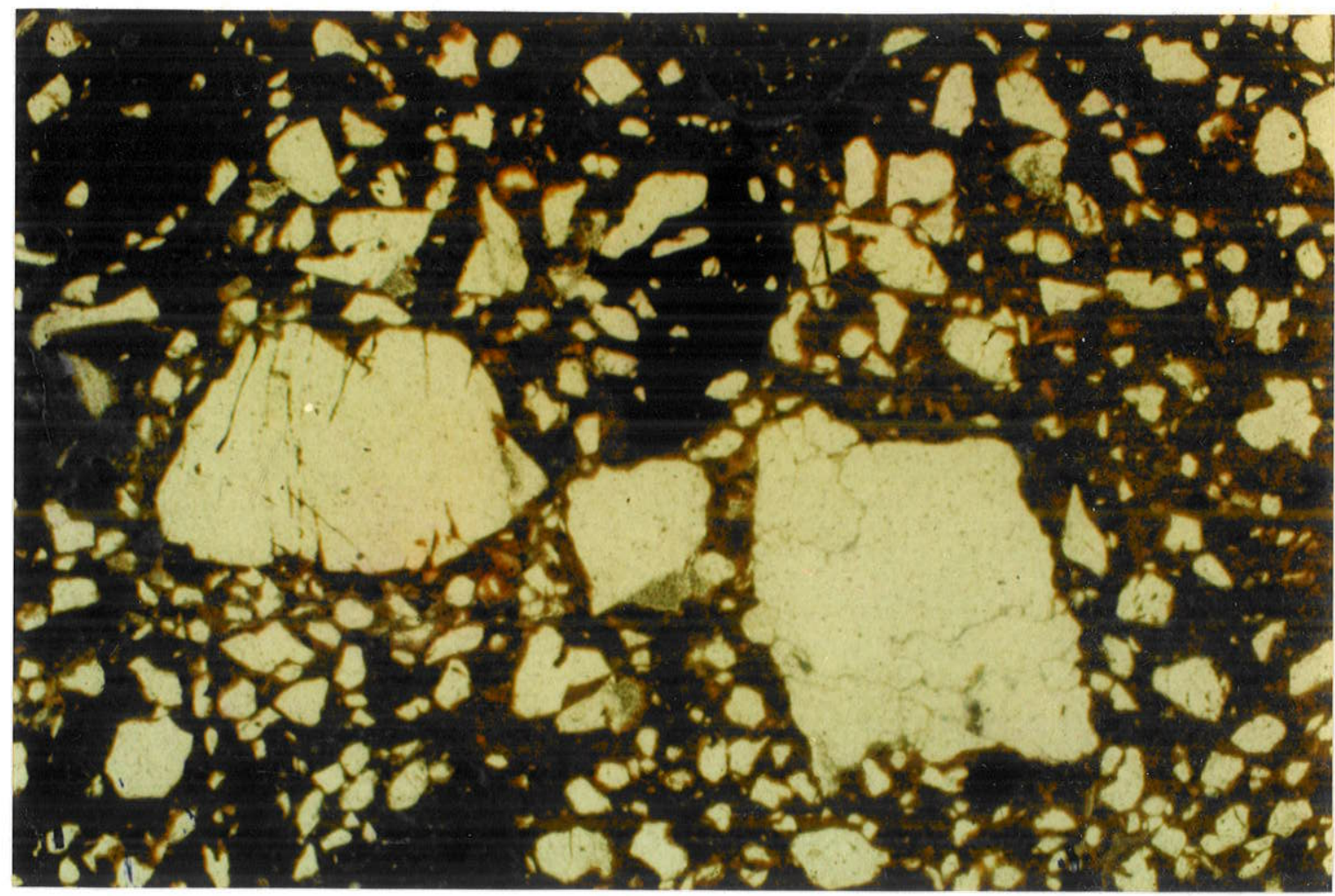

Fotografia 32. Colúvio apresentando matriz argilosa avermelhada, provavelmente laterizada. Os grãos do arcabouço são melhor identificados na foto 43. Amostra H-CO-09. Rua Eirunepê, Capela do Socorro. Fotomicrografia. Nicóis paralelos. Aumento 2,5 X.

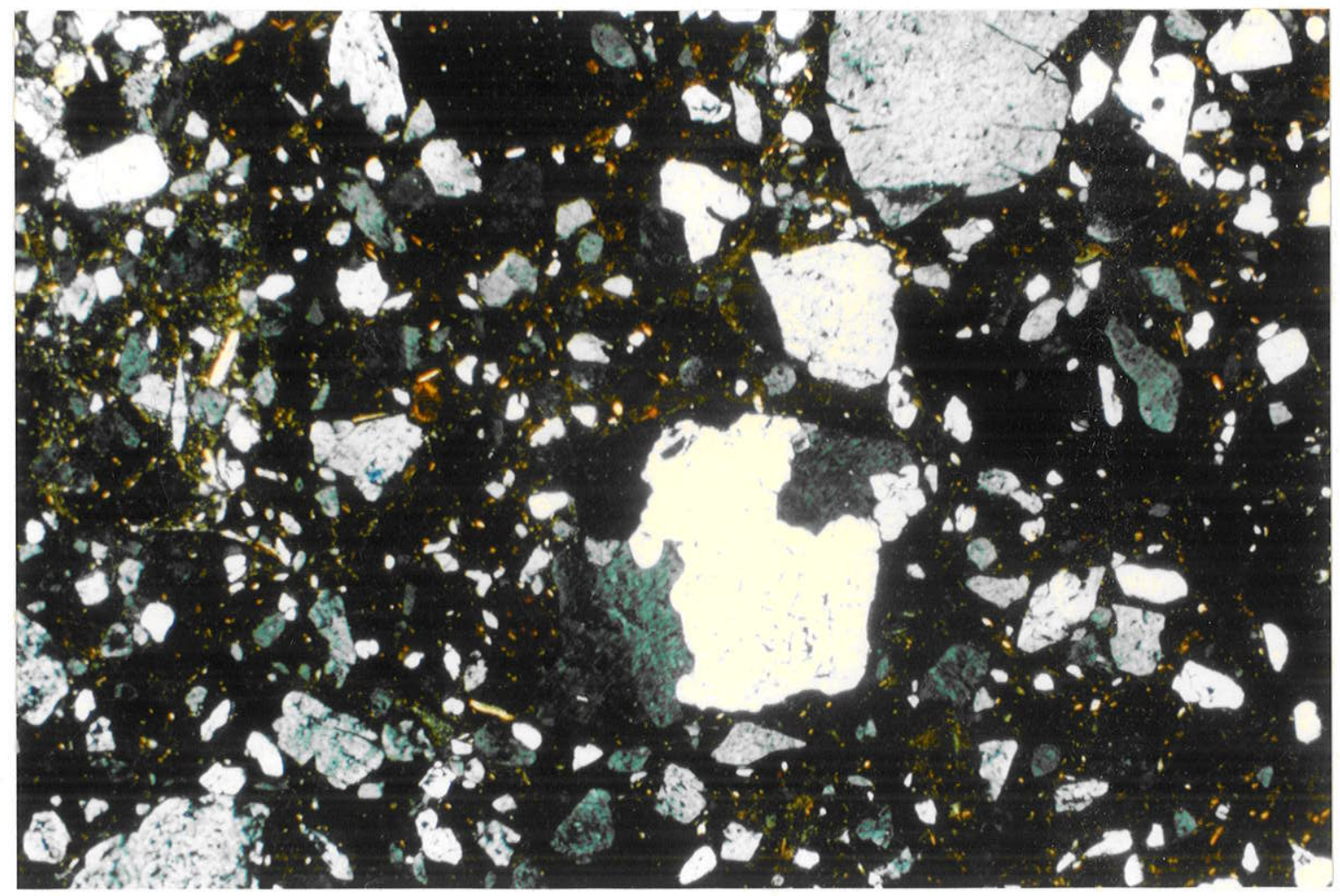

Fotografia 33. Grãos de quartzo e quartzitos. Notar a presença de grãos oxidados. Amostra H-CO09. Rua Eirunepê, Capela do Socorro.Fotomicrografia.Nicóis paralelos.Aumento $2,5 \mathrm{X}$ 


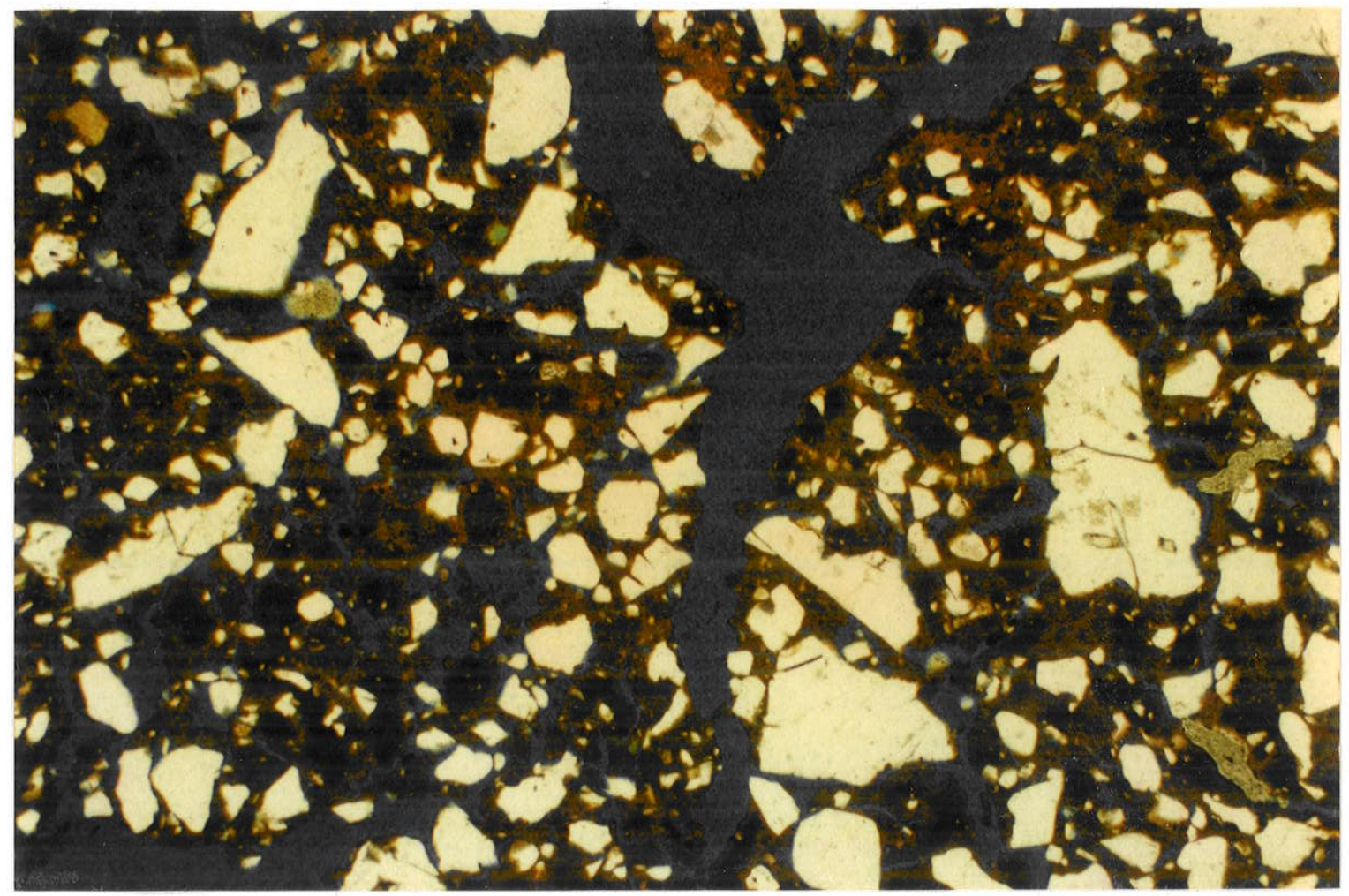

Fotografia 34. Grãos sustentados por matriz argilosa com indícios de laterização (pontos escuros). O arcabouço é constituído predominantemente por quartzo, verificando-se como mineral acessório a turmalina (canto noroeste da foto). Notar a presença marcante de poros em filetes interligados com largura variada. Amostra H-CO-11. Rua Percépolis, Capela do Socorro. Fotomicrografia. Nicóis paralelos. Aumento 2,5 X.

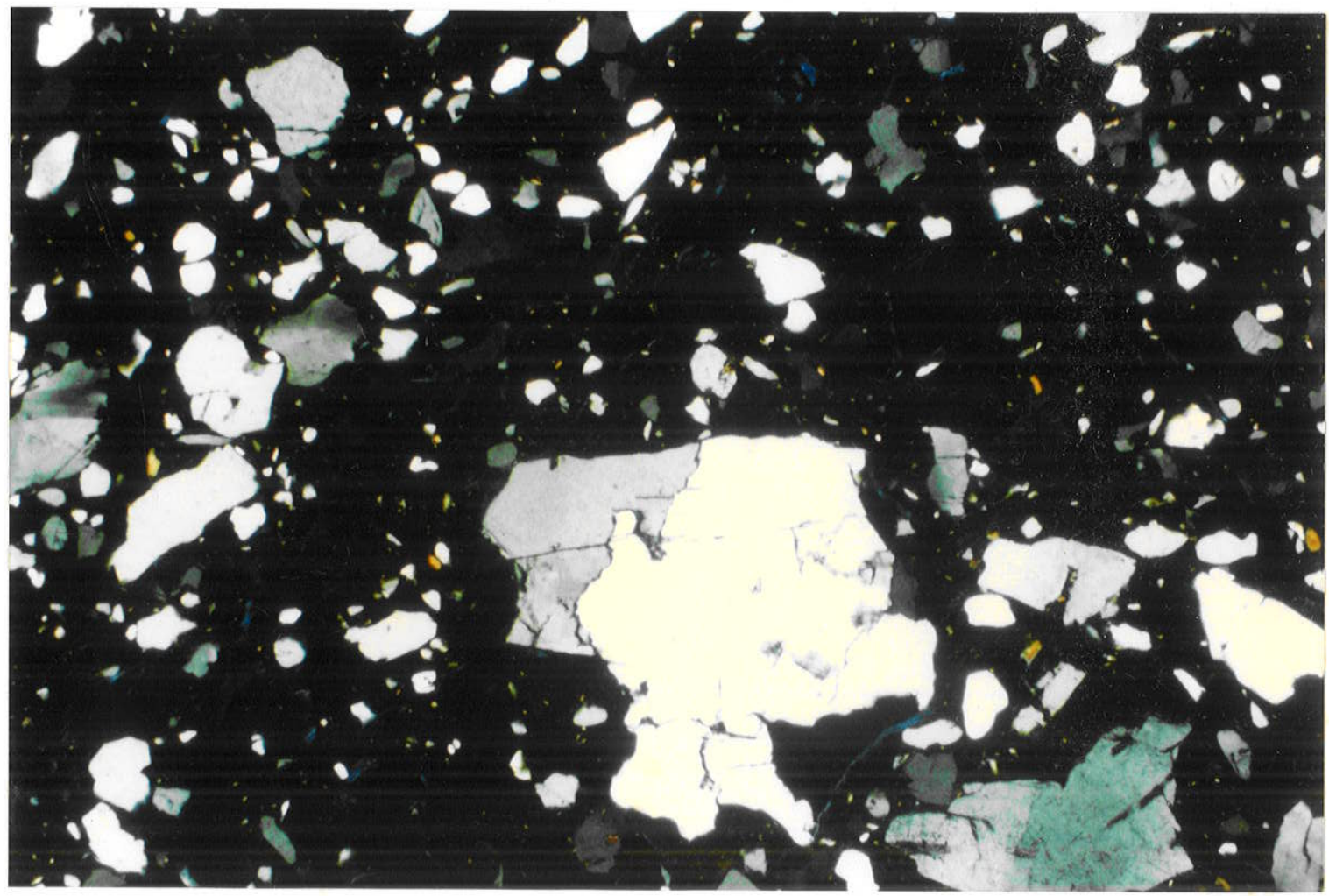

Fotografia 35. Fragmento lítico de quartzo (grão maior). Notar a presença de poros. Amostra HCO-11. Rua Percépolis, Capela do Socorro. Fotomicrografia. Nicóis paralelos Aumento 2,5 X. 


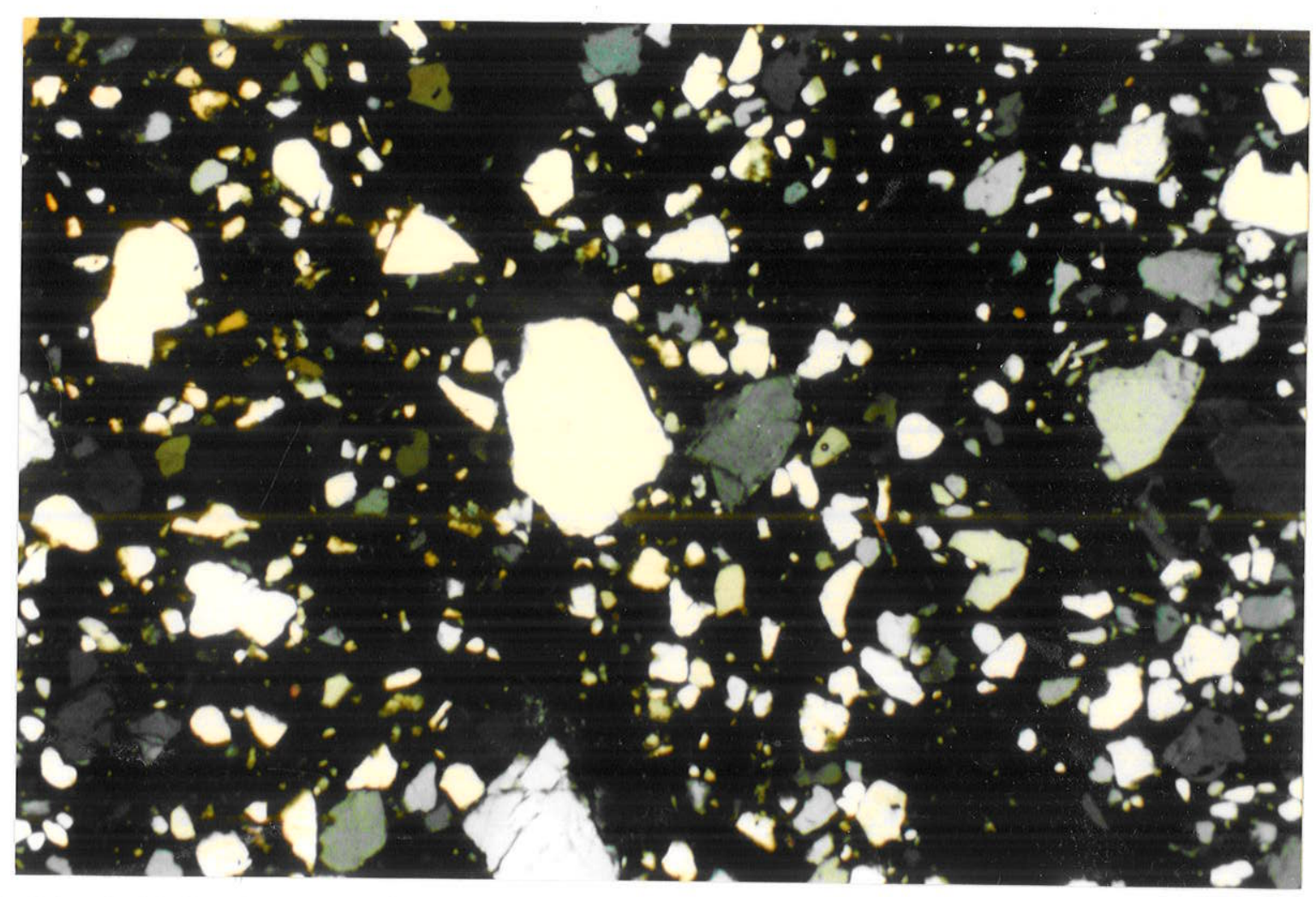

Fotografia 36. Colúvio apresentando predominantemente grãos de quartzo de dimensões variadas em matriz argilosa abundante.Amostra H-CO-20. Avenida São Miguel, Zona Leste. Fotomicrografia. Nicóis cruzados. Aumento 2,5 X.

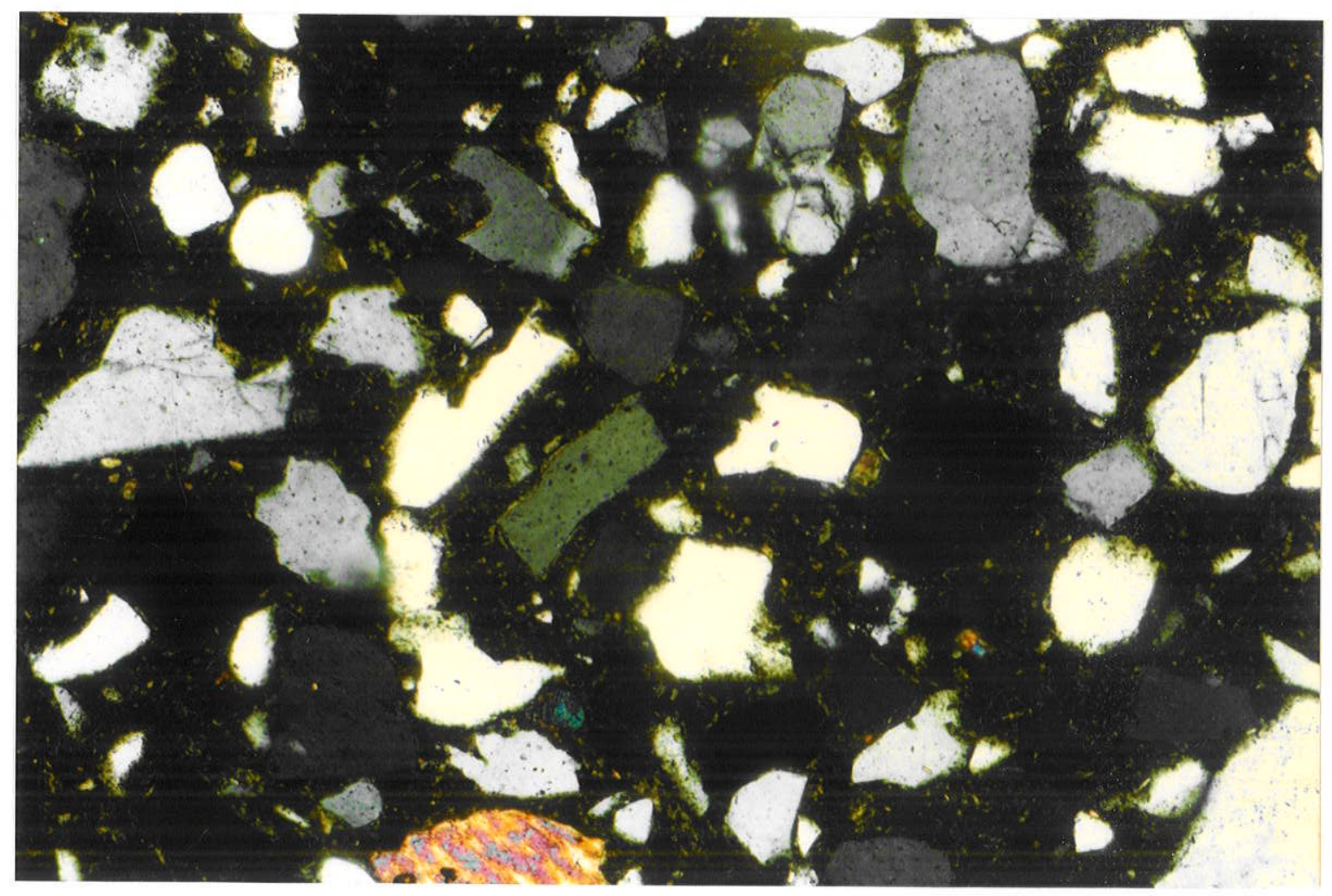

Fotografia 37. Detalhe da foto anterior, mostrando a turmalina como grão acessório. Amostra H-CO-20. Avenida São Miguel, Zona Leste.

Fotomicrografia. Nicóis cruzados. Aumento 2,5 X. 


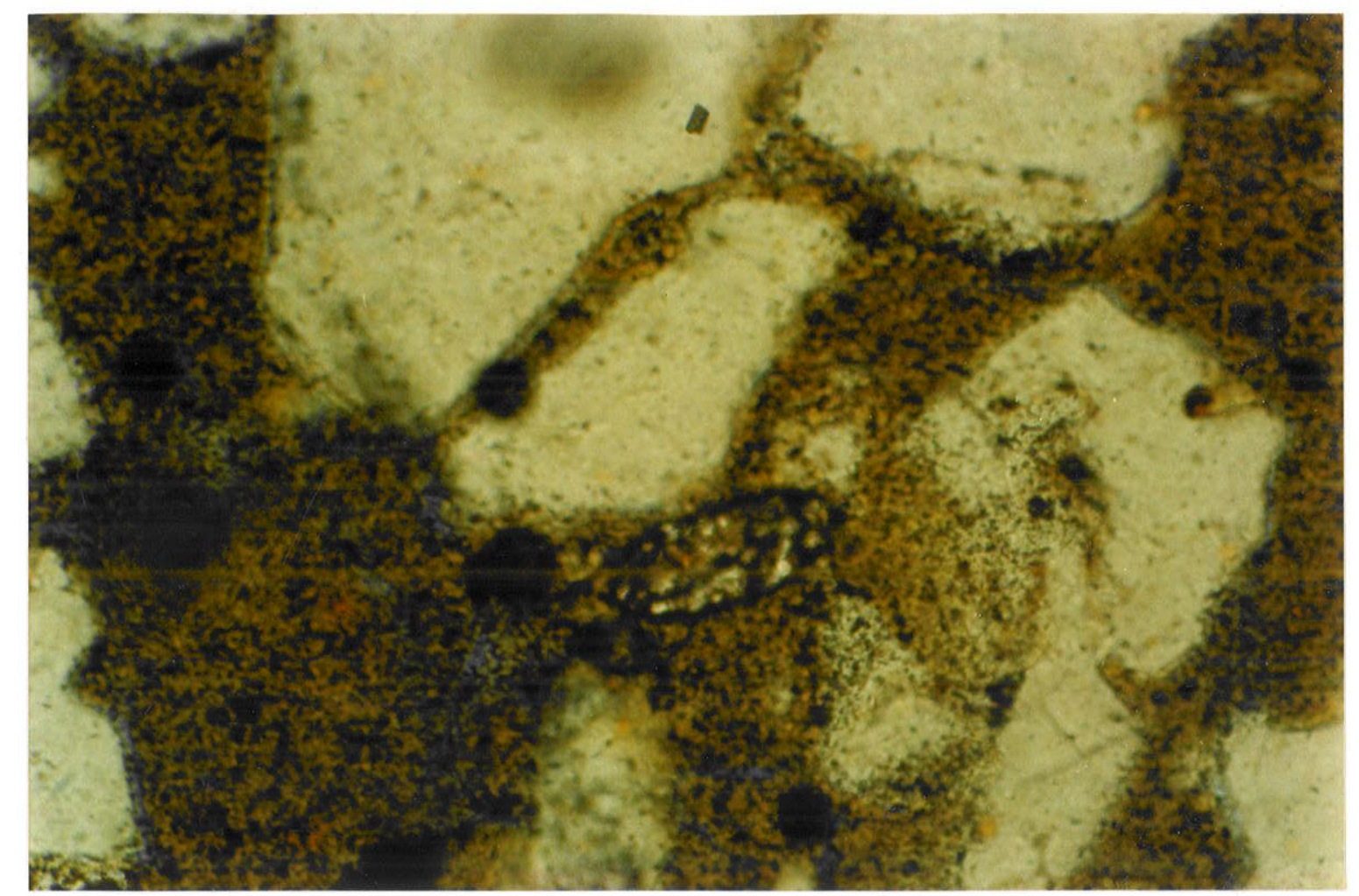

Fotografia 38. Grãos de titanita ao centro da foto. Amostra H-CO-19. Avenida São Miguel, Zona Leste. Fotomicrografia. Nicóis cruzados. Aumento 2,5 X.

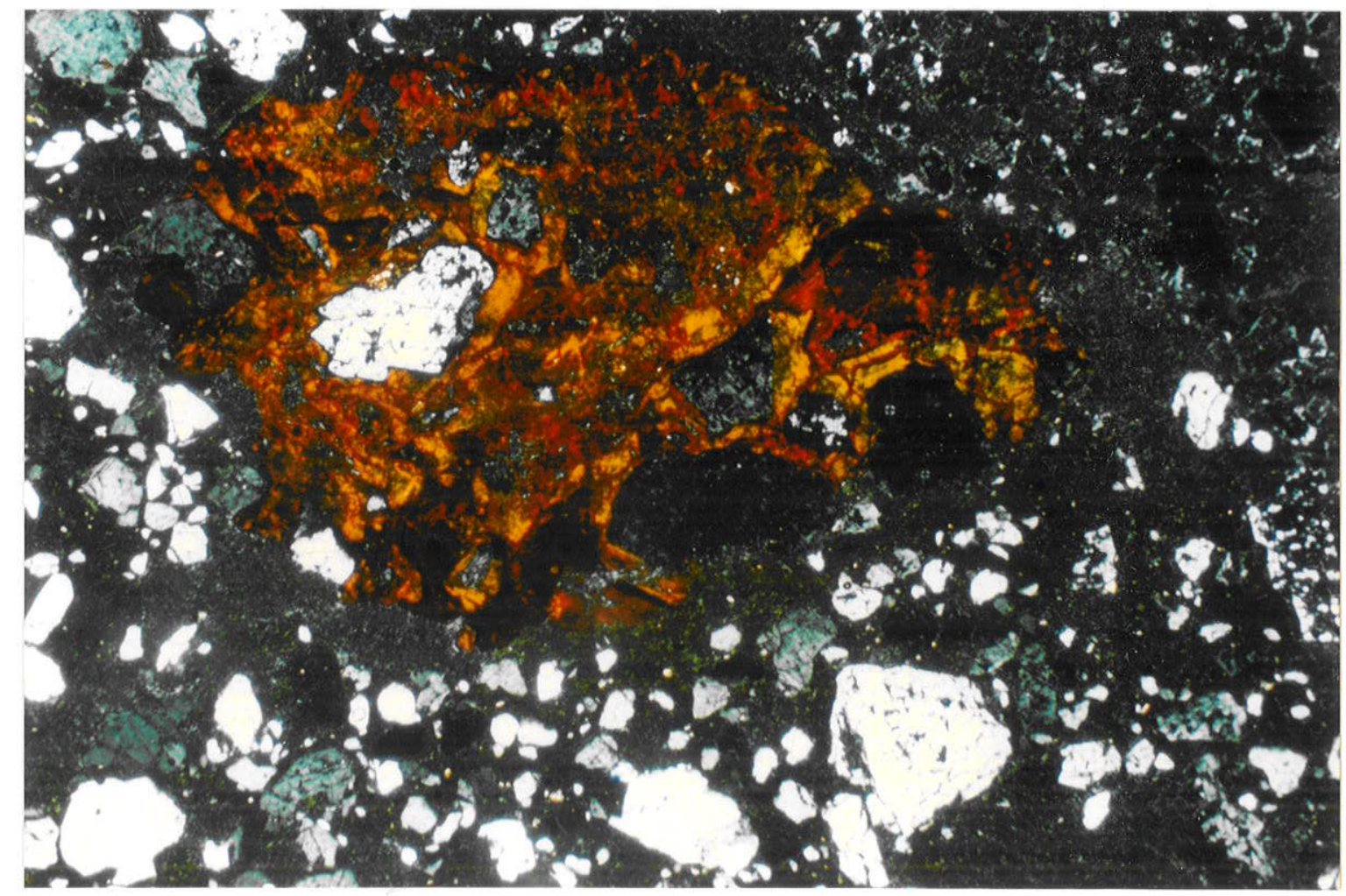

Fotografia 39. Fragmento laterizado. Amostra H-CO-19. Fotomicrografia. Nicóis cruzados. Aumento 2,5 X. 


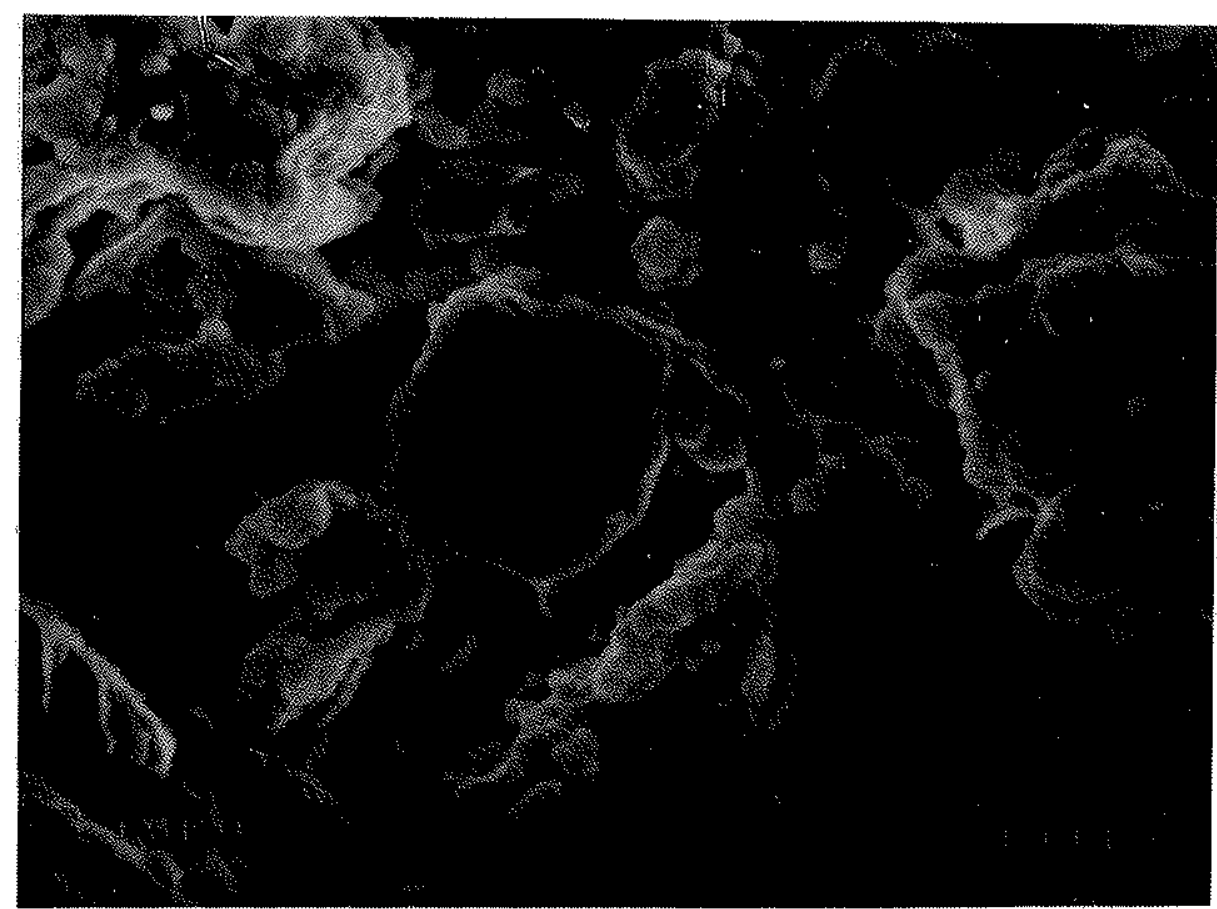

Fotografia 40. Caulinita com forma placóide, com pequena dimensão, com bordas arredondadas a pouco angulosas. Amostra H-CO-19. Avenida São Miguel, Zona Leste. MEV.

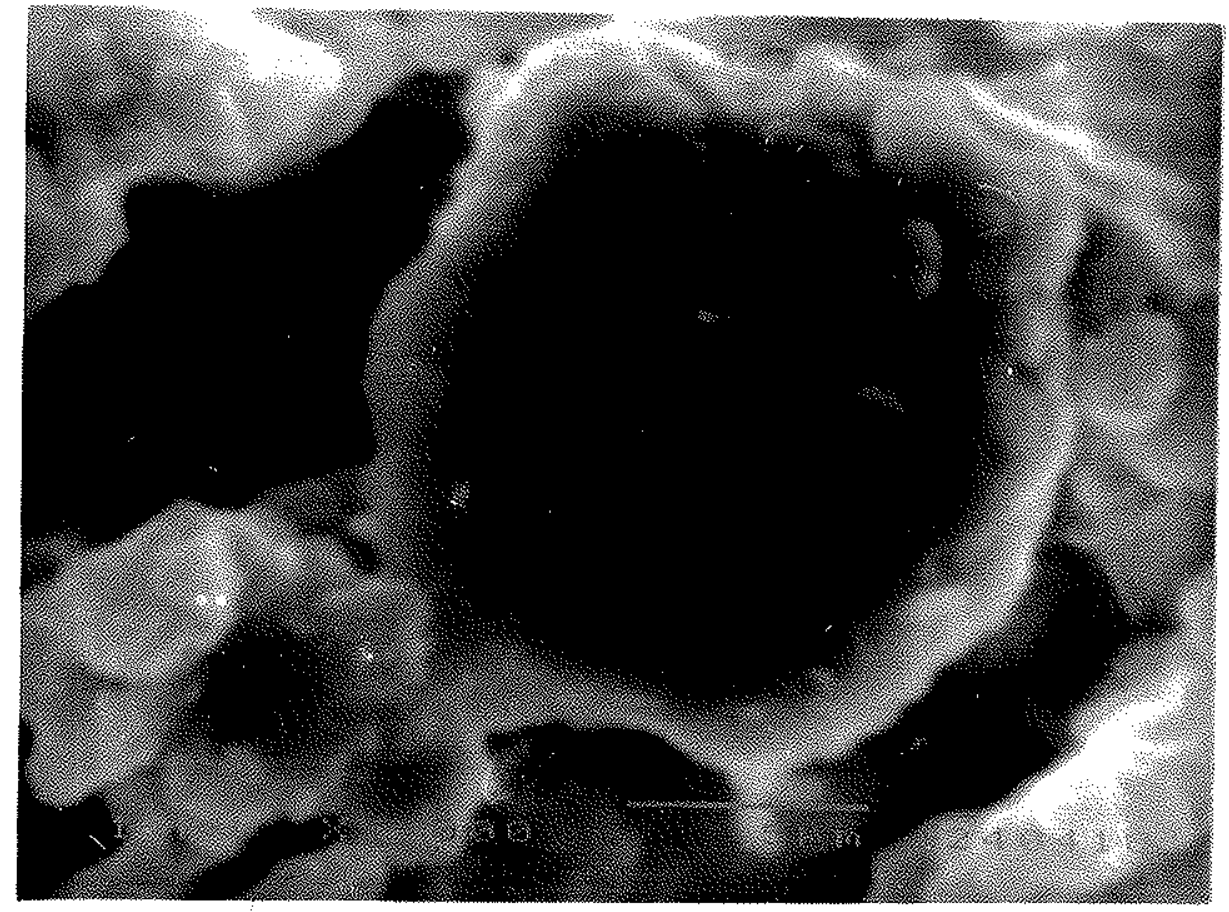

Fotografia 41. Detalhe da imagem anterior. 
Os colúvios presentes na área de estudo foram melhor observados na Zona Sul do município, na região de Campo Limpo e Capela do Socorro, onde assentam-se predominantemente sobre solo saprolítico (alteração de rochas do embasamento da bacia). Nessa área, assim como na Zona Norte, próximo a Serra da Cantareira, observa-se relevo mais acidentado, que certamente influenciou na formação desses depósitos, os quais estariam relacionados, em sua maioria, a processos de movimento lento de massa ao longo das encostas.

Foram notados ainda, colúvios assentados sobre sedimentos terciários da bacia, notadamente sobre depósitos lamíticos da Formação Resende. Ocorrem pontualmente espalhados na área de estudos, sendo observados na Zona Sul, à Rua. Cândido Mel e Francisco Mel na Cidade Dutra, à Rua. Fonseca Brasil no Morumbi, e Av. São Miguel (C.H. Garagem) na Zona Leste, sendo esses últimos depósitos situados sobre sedimentos da Formação São Paulo.

Embora depositados sobre diferentes substratos, em geral, os colúvios não apresentam correlação direta entre a sua textura e composição com aquelas presentes na rocha subjacente, pois tratam-se na maioria das vezes, de material pedogeneticamente evoluído.

Independentemente das rochas ou solos que lhes deram origem, nota-se grande semelhança entre os colúvios encontrados na área, não somente em relação a sua aparência (espessura, textura e coloração), mas também em termos de suas características geotécnicas.

Nos ensaios para classificação MCT discutidos no item 5.7, mostram que a grande maioria dos colúvios apresentam comportamento laterítico. As exceções encontradas referem-se à amostra H-CO 15, coletada fora da área de estudos na Estrada dos Romeiros em frente a Serra do Boturuna, em Santana do Parnaiba, à amostra H-CO-29, situada próxima a Estrada dos Funcionários Públicos, Zona Sul, e à amostra H-CO-13 extraída em afloramento à Rua Gervásio Leite Rabelo, Jd.Peri, Zona Norte.

Esse último depósito assenta-se sobre xisto fraturado, apresentando o colúvio, fragmentos da rocha subjacente, sendo classificado segundo o método MCT, como NS'NA', exibindo portanto comportamento de solo saprolítico, não favorável do ponto de vista geotécnico. Esses depósitos coluviais, por ainda exibirem fragmentos de xisto em seu arcabouço, mostram certa imaturidade textural, que denotaria transporte rápido, associado a movimentos de massas na formação do mesmo. As características apontadas poderiam explicar a semelhança, do ponto de vista geotécnico, desses depósitos com a rocha subjacente. 
Em relação às stone lines observadas, essas ocorrem como já mencionado, na porção basal dos colúvios, geralmente em contato com uma camada menos permeável, mais endurecida, por vezes laterizada (Fotografia 28), marcando uma superfície que acompanha a topografia da encosta.

As stone lines observadas na área, diferentemente dos depósitos finos sobrejacentes, guardam ainda semelhanças com essas rochas do substrato ou com aquelas situadas nas proximidades desses depósitos, comprovando que os stone lines teriam sua gênese relacionada a evolução geológico-geomorfo-pedológica do relevo onde se inserem.

As stone lines da área estudada exibem composição variada, predominando seixos angulosos a subarredondados de quartzo e quartzito, fragmentos líticos geralmente laterizados e até agregados de turmalina, como os encontrados no colúvio situado no Bairro do Morumbi (Fotografia 28). O tamanho das partículas varia desde seixos com poucos centímetros (Fotografias 23 a 28 ), até calhaus decimétricos (Fotografia 21).

Quanto às fases de coluviamento presentes na área, notou-se a ocorrência generalizada de uma fase de coluviamento bem pronunciada, com presença de stone line. Localmente foram observadas até 3 fases de coluvionamento, preservadas em topo de encosta.

$\mathrm{O}$ perfil apresentando as 3 fases citadas situa-se à R. General Moreira Couto, em Guaianazes, Zona Leste (Fotografia 42 ). Neste observou-se depósitos de stone line na base do talude de corte, com cerca de $0.5 \mathrm{~m}$ de espessura, constituído por seixos a calhaus subangulares a subarredondados, predominantemente de quartzo e quartzito, sobreposto por depósito avermelhado argiloso com $1 \mathrm{~m}$ de espessura apresentando em seu arcabouço fragmentos de sedimentos lamíticos da Formação Resende. Sobre este assenta-se uma segunda geração de stone line, um pouco menos espessa que a anterior, apresentando seixos menores $(2$ a $3 \mathrm{~cm}$ ), de quartzito em sua maioria, sobreposto por depósito argilo-arenoso poroso, com cerca de $0.5 \mathrm{~m}$ de espessura, marromavermelhado, exibindo também fragmentos de sedimentos lamíticos da Formação Resende.

Fechando essa seqüência nota-se um espesso pacote, com aproximadamente $3 \mathrm{~m}$ de espessura, com predomínio de clastos com dimensões diferenciadas em duas classes principais. A primeira apresenta seixos/calhaus com 6 a $10 \mathrm{~cm}$, e a segunda fragmentos entre 20 e $30 \mathrm{~cm}$, comumente fraturados, com arestas subangulosas. A matriz argilosa desse depósito é pouco abundante, e apresenta coloração avermelhada. Os clastos são constituídos por quartzo, quartzito e rocha máfica alterada. 
Ainda na Zona Leste, à Avenida. Inácio Monteiro, Cidade Tiradentes, a alguns kilômetros do afloramento descrito anteriormente, verificou-se a ocorrência de duas gerações de colúvio (Fotografia 43). A primeira está assentada sobre rocha xistosa alterada, exibindo stone line na base, sobreposta por depósito argiloso avermelhado, com cerca de 1 a $1.5 \mathrm{~m}$ de espessura, sobre o qual depositou-se, em contato discordante, uma segunda geração de colúvio, no qual não foi verificada a presença de stone line. Essas duas fases de coluvionamento poderiam tentativamente ser correlacionadas às duas descritas no ponto anterior, em Guaianazes, por apresentarem semelhanças quanto à textura e coloração. A terceira fase de coluvionamento, verificada no afloramento citado, devido a sua grande espessura, presença de seixos fraturados e situação topográfica, poderia ter sua origem atribuída a atividades neotectônicas. 


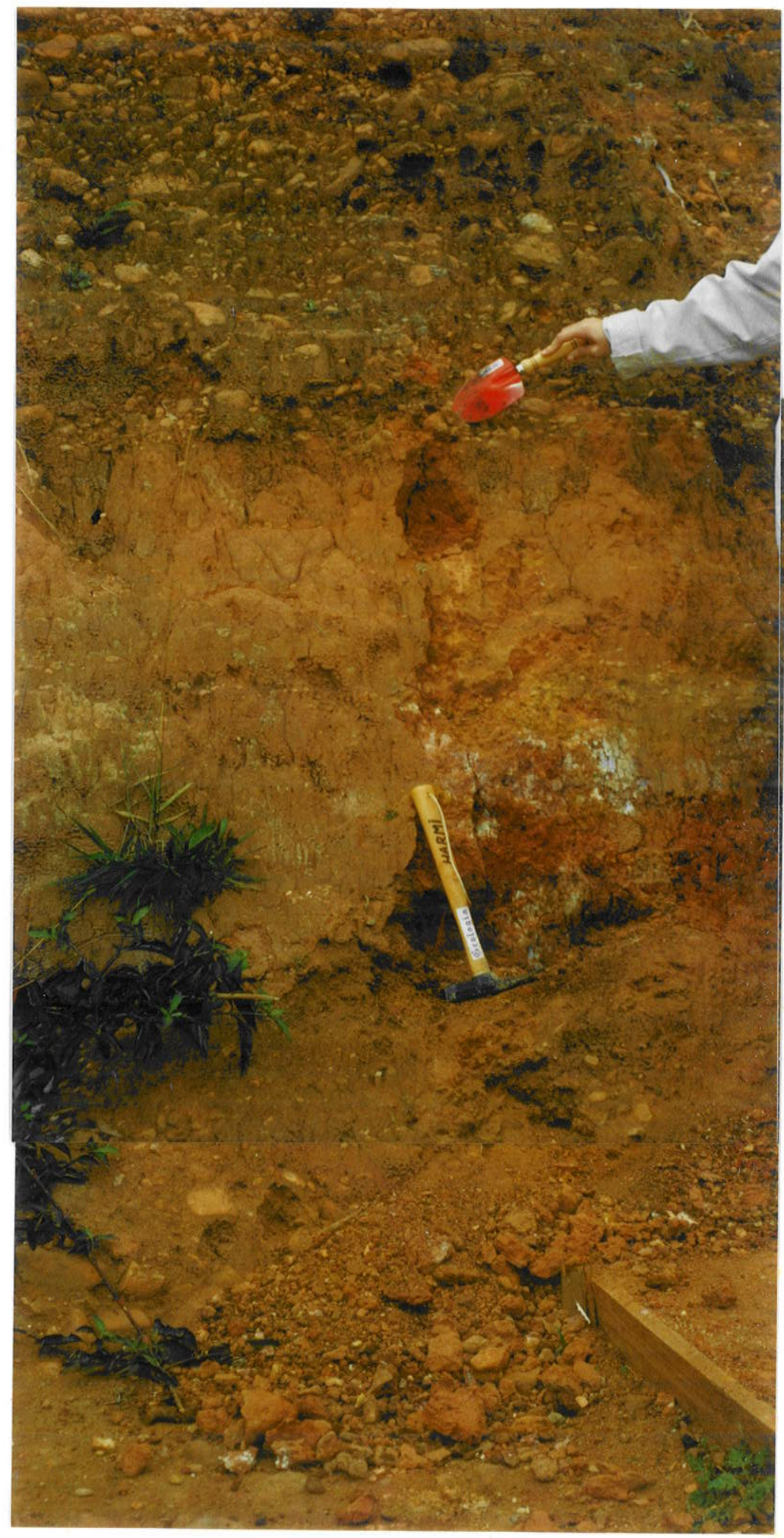

Fotografia 42. Afloramento apresentando três gerações de colúvio. Rua General Moreira Couto, Guaianazes. 


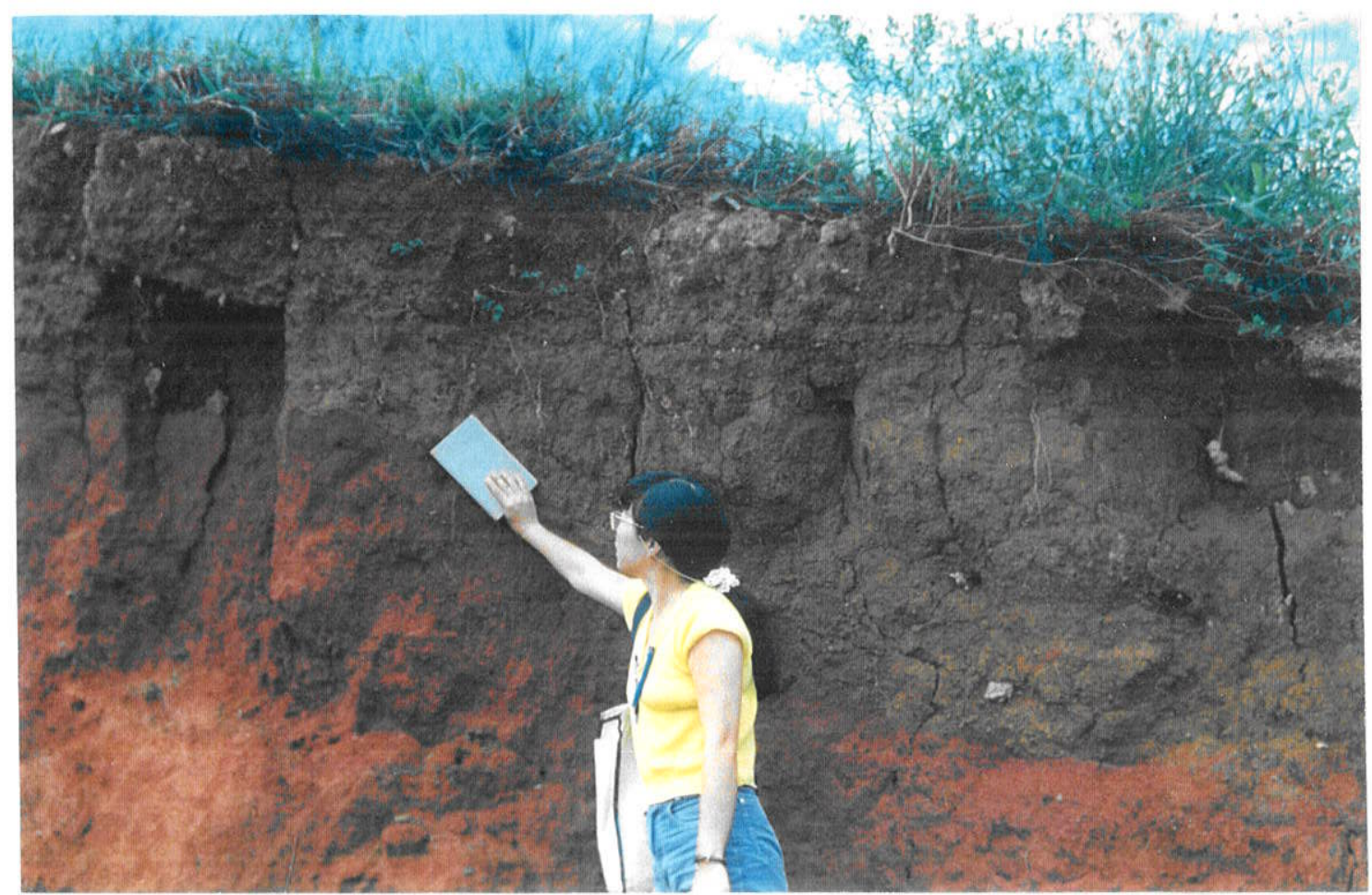

Fotografia 43. Afloramento apresentando duas gerações de colúvio. Avenida Inácio Monteiro, Cidade Tiradentes.

Quanto às idades dos depósitos coluviais presente na área, as datações efetuadas em fragmentos de carvão situados no topo dos depósitos coluviais, coletados no Jardim Paranapanema em Campo Limpo (2 amostras), à Rua Eirunepê, Capela do Socorro, e Av. S. Miguel, C. H. Garagem, forneceram respectivamente idades de 610 +/- 80 anos AP; AD 1958- 1962 ou AD 19771980; AD 1957-1959 e $3000+/-140$ anos AP.

As idades mais recentes indicam processo de coluvionamento atuante após 1950 provavelmente induzidos por ações antrópicas como desmatamento de encostas. A idade obtida para a área do Jardim Paranapanema praticamente coincide com a época de implantação do primeiro loteamento nessa área, no ano de 1970. Os fragmentos de carvão datados marcam uma linha, talvez uma superfície, bem definida, a partir da qual ocorreriam esses depósitos atuais, que apresentam cerca de 0.3 a $0.5 \mathrm{~m}$ de espessura, podendo ser denominados de tecnogênicos, segundo conceituação citada no próximo item. 
As idades de $610+/-80$ anos AP e $3000+/-140$ anos AP indicam fases distintas de coluvionamento. No entanto, devido a dificuldade de se encontrar material adequado para ser submetido a datação pelo método radiocarbono, e ainda devido a própria natureza desses depósitos, com desenvolvimento em encosta, torna-se dificil a correlação entre os diversos colúvios encontrados na área estudada.

Ainda assim, algumas considerações, ainda que preliminares, podem ser efetuadas em relação as idades desses depósitos. A idade de $610+/-80$ anos AP obtida em fragmentos de carvão situados no topo de camada coluvial à Rua Andrea Sansovino, Jd. Paranapanema, Campo Limpo, poderia indicar que parte dos depósitos coluviais observados na Zona Sul pertenceriam a uma fase mais recente.

Já a idade de 3000 +/- 140 anos AP observada em depósitos coluviais situados na Zona Leste, à Av. S. Miguel, C. H. Garagem, representaria a fase principal de coluvionamento presente na área.

Apesar de não ter sido datada, não descarta-se a possibilidade da existência de uma fase ainda mais antiga, pleistocênica, provavelmente relacionada àquela descrita por MELO et al. (1987) que situaram depósitos coluviais presentes na área da Grande São Paulo entre $30000 \mathrm{e}$ 52000 anos AP.

Os depósitos descritos pelos autores referem-se a associações colúvio-aluviais presentes em zonas de planície aluvial, pouco descritos na área de estudo. LORSCHEITTER et al. (1990) sugerem através de análises palinológicas efetuadas em sedimentos coletados na estrutura circular de Colônia, no extremo Sul do município, condições climáticas mais secas após 28180 anos AP, que poderiam estar associadas na área de estudos, a uma fase de coluvionamento mais antiga, porém não datada.

Deve-se mencionar os estudos estratigráficos sistemáticos efetuados no médio vale do rio Paraíba do Sul ( e.g. MELLO 1992; MELLO et al. 1995), onde foi possível o reconhecimento de diferentes unidades aloestratigráficas formalmente definidas nas quais são englobadas depósitos coluviais e aluviais de gerações distintas. No presente trabalho não foi possível a individualização e distinção de unidades formais devido principalmente. a ausência de fatores imprescindíveis no estudo da sedimentação quaternária, presentes na área do médio rio Paraiba do Sul (MELLO et al. 1995): existência de grande quantidade de boas exposições dos depósitos associados a feições 
geomorfológicas, e a ocorrência de níveis orgânicos nas camadas coluviais, passiveis de serem datados.

\subsection{DEPÓSITOS TECNOGÊNICOS}

OLIVEIRA (1990) denominou de depósitos tecnogênicos (originados pela técnica) os depósitos formados pelo resultado da atividade humana, segundo conceituação de CHEMEKOV (1982). OLIVEIRA (1990) classificou tentativamente esses depósitos em três tipos principais: construídos (aterros, corpos de rejeito, etc); induzidos (assoreamento, aluviões modernos, etc) e modificados (depósitos naturais alterados tecnogenicamente por efluentes, adubos, etc).

Já PELOGGIA (1994) denomina de "coberturas remobilizadas" os capeamentos superficiais inconsolidados, ricos em detritos de origem humana, resultantes de movimentação por enxurradas e gravidade de solos, entulhos e lixos lançados nas encostas urbanas.

Os dois tipos de depósitos descritos anteriormente são de ocorrência bastante comum na área de estudo. A intensa ocupação verificada na cidade de São Paulo contribui a cada dia para a formação desses depósitos, quer seja nas encostas ocupadas, nas áreas de várzeas (Anexo B, Figura 13) em locais onde executam-se grandes obras que requerem movimentos de terra de grandes proporções.

As coberturas aluviais presentes no município embora ocupem extensas áreas, encontram-se freqüentemente capeadas por aterros de constituição bastante heterogênea, variando desde material de bota-fora (Fotografia 44), contendo plástico, restos de material de construção, tecidos etc., até solos saprolíticos e de sedimentos compactados ou lançados. As espessuras do aterro variam de menos de $1 \mathrm{~m}$ até cerca de $5 \mathrm{~m}$ (Anexo $\mathrm{B}$ ).

$\mathrm{Na}$ Fotografia 45 é apontado um exemplo de depósito tecnogênico, que mostra uma antiga área de "bota-fora", onde atualmente assenta-se uma favela, em área de risco de escorregamento. A Fotografia 46 retrata uma encosta ocupada por favela, situada em Campo Limpo, onde ocorreu escorregamento em dezembro de 1991. O local, também estudado pela autora desse trabalho, foi utilizado como exemplo na definição do termo "coberturas remobilizadas" por PELOGGIA (1994). 


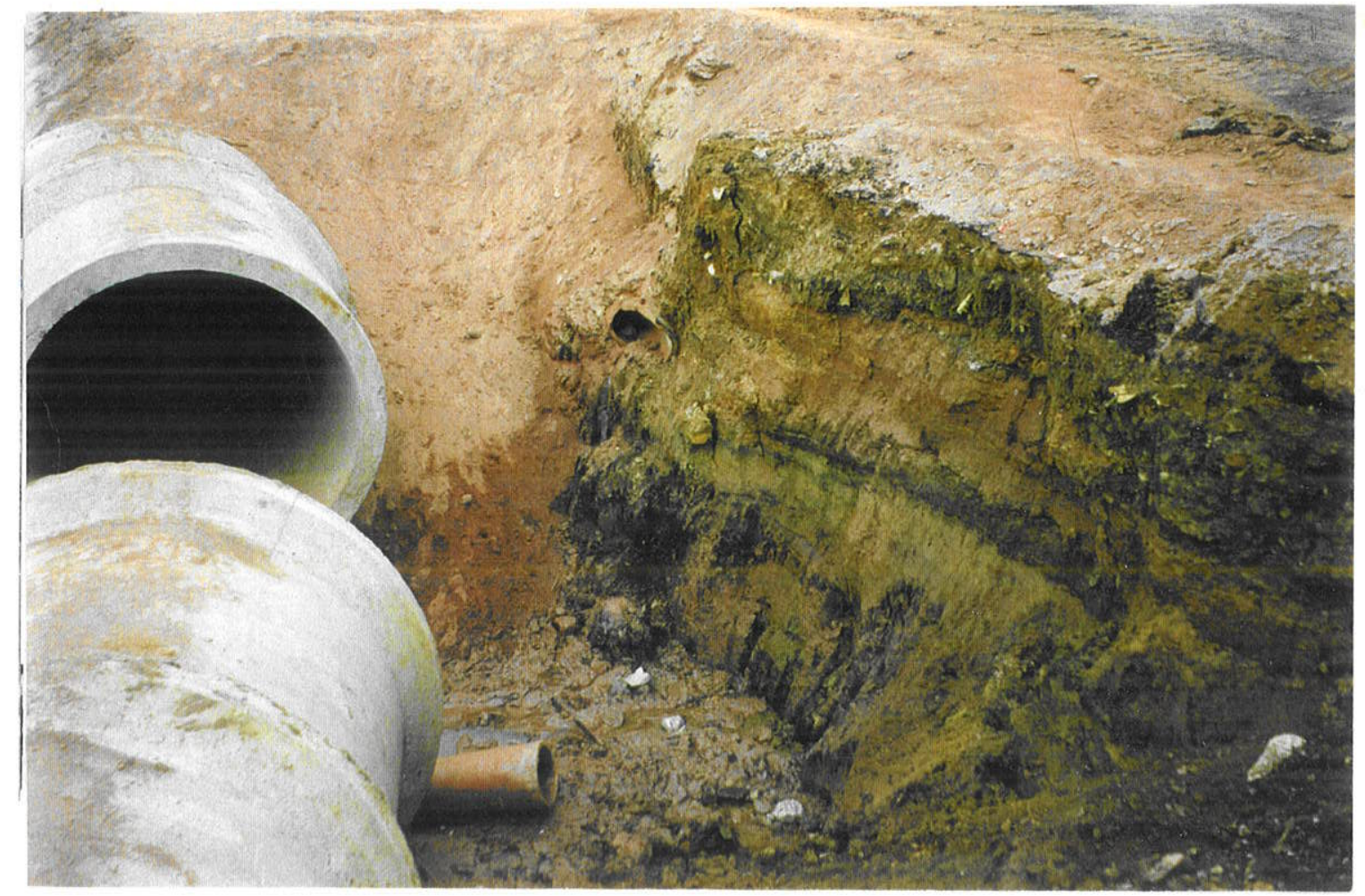

Fotografia 44. Depósitos aluviais argilosos cobertos por aterro de constituição variada. Rua General Moreira Couto, Guaianazes.

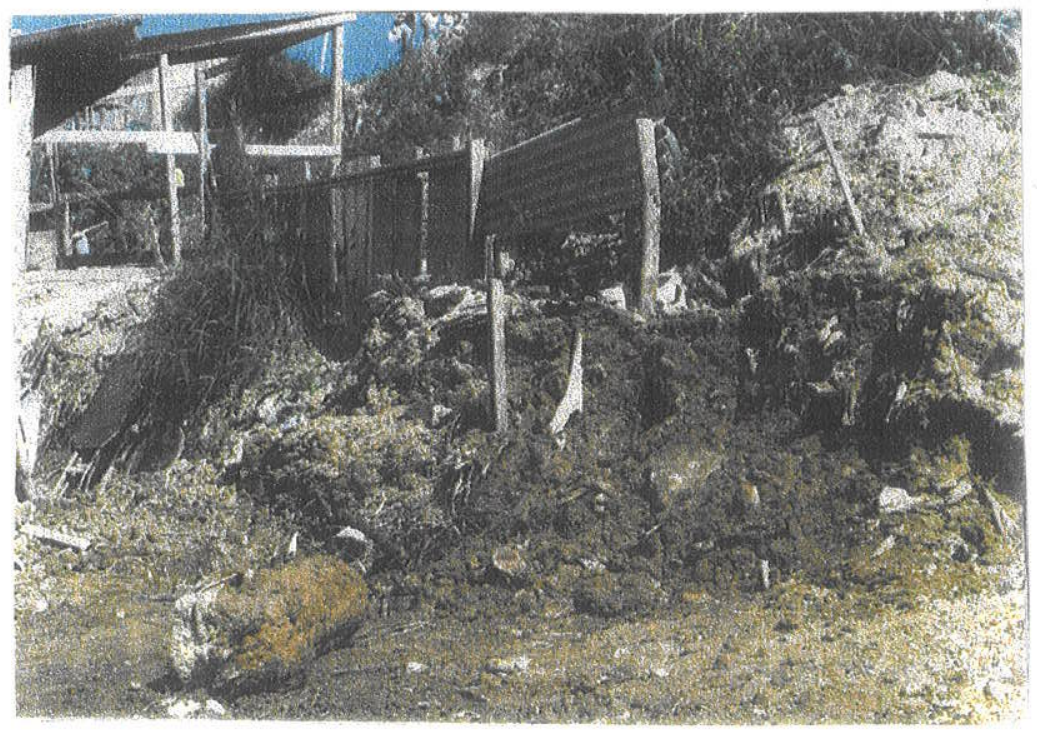

Fotografia 45. Favela do Jardim Sandra, Campo Limpo. Área de antigo bota-fora onde nota-se talude escavado apresentando depósito tecnogênico constituido por solo argilo-arenoso, além de fragmentos de madeira, plástico, tecido e material de construção. 


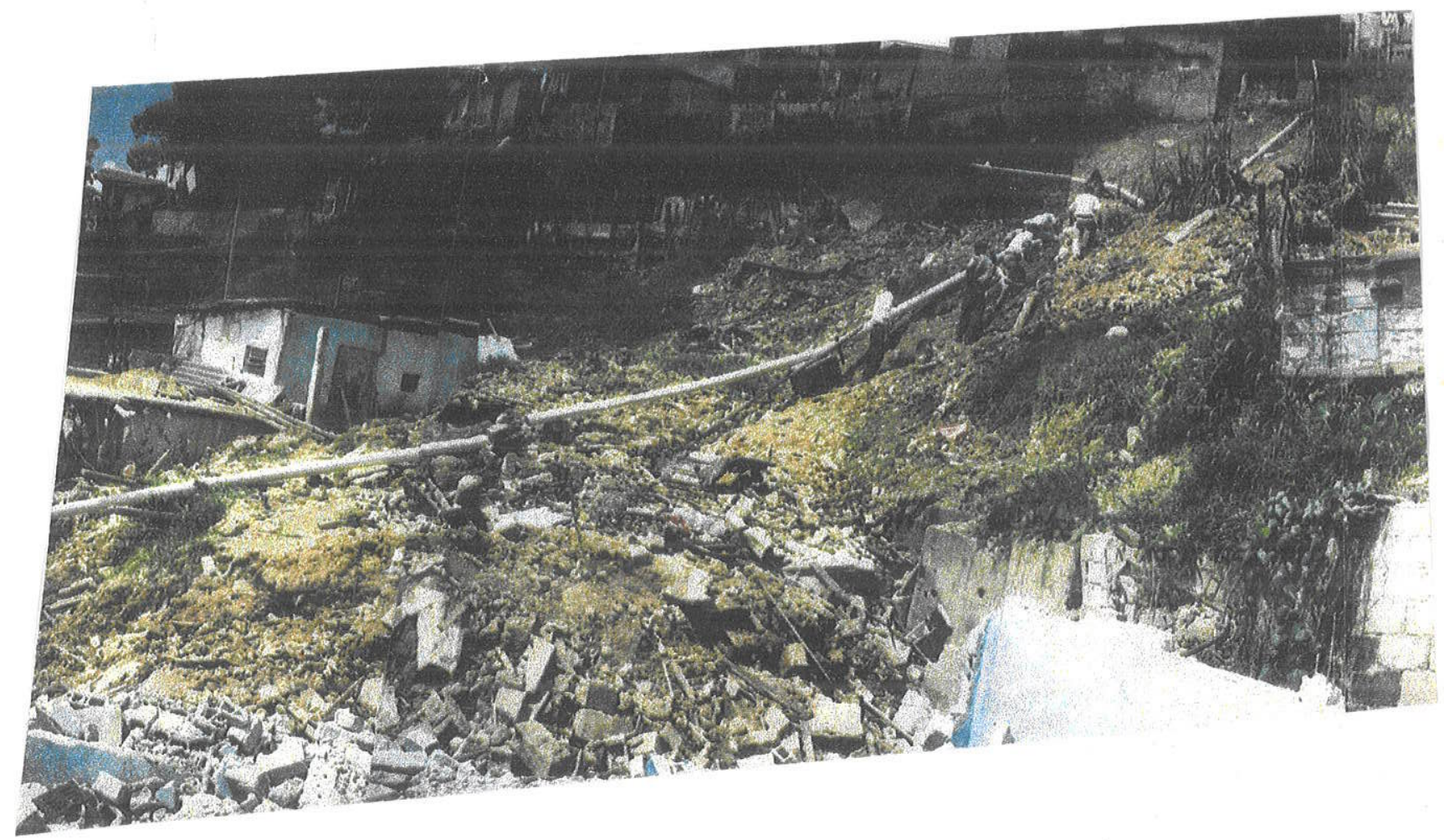

Fotografia 46. Favela Peinha, Campo Limpo. Escorregamento ocorrido em 1991 atingindo depósitos remobilizados. 


\subsection{DEPÓSITOS ALUVIAIS}

\subsubsection{CONSIDERAÇÕES GERAIS}

Apesar dos depósitos aluviais quaternários ocuparem grande parte da área em estudo, raramente são notados cortes onde pode-se observar uma sequência completa desses estratos, devido primeiramente a ocupação intensa desses locais, e também, à situação topográfica em que se encontram.

Esses sedimentos foram detalhadamente descritos por ALMEIDA et al. (1984), na região de Itaquaquecetuba. Constituem-se da base para o topo da camada, por conglomerado formado por seixos e blocos de quartzo e quartzito, sobrepostos por areias médias com estratificações cruzadas acanaladas, apresentando até $2 \mathrm{~m}$ de espessura, com raros fragmentos de madeira fóssil carbonificada, seguidos por sedimentos areno-argilosos turfáceos com espessura variando de 1,5 a $2 \mathrm{~m}$.

$\mathrm{Na}$ área de estudos os depósitos aluviais desenvolvem-se principalmente na extensas planícies aluviais dos rios Tietê, Pinheiros, Tamanduateí, Aricanduva, Cabuçu e seus principais tributários (Anexo A).

Como mencionado no item 5.3 é bastante freqüente a presença de camada de aterro capeando os sedimentos aluviais podendo esses últimos alcançar até $15 \mathrm{~m}$ de espessura (observados somente em perfil de sondagem).

O conglomerado basal observado nesses depósitos apresenta tons amarelados a esbranquiçados sendo constituído por seixos a calhaus de quartzo, sobreposto por areias grossas a finas apresentando grãos arredondados a subarredondados de quartzo e matriz argilosa. O pacote argiloso situado geralmente no topo dessa sequeência, apresenta colorações claras, com tons acinzentados, constituído por argila plástica geralmente sobreposto por argila orgânica, cinza escura a preta. A seqüência granodecrescente descrita acima encontra-se comumente interrompida, denotando diversos ciclos de sedimentação referentes ao reordenamento de drenagens, causados por fatores climáticos ou tectônicos.

Neste trabalho foram verificadas pequenas exposições desses depósitos, todos situados próximos a drenagens atuais, em locais onde estavam sendo executadas obras de engenharia. 
A presença de terraços fluviais, esperada em drenagens com padrão meandrante, já descrita anteriormente (AB'SABER 1957, 1980), é atualmente pouco observada na área de estudos. Próximo ao Córrego Morro do $\mathrm{S}$, no entroncamento da atual Av. Carlos Caldeira Filho, com a Estrada de Itapecerica, pôde-se efetuar a descrição de um perfil, de um provável terraço, com $2,6 \mathrm{~m}$ de espessura (Figura 16). Observou-se no local, uma camada basal de aproximadamente $0.5 \mathrm{~m}$ de areia grossa, com intercalações de lentes de argila, seguida de camada de argila orgânica arenosa, cinza escura, com intercalações de areia grossa, apresentando esse pacote cerca de $1.1 \mathrm{~m}$, onde coletou-se amostra contínua com $83 \mathrm{~cm}$, para análise palinológica e datação. Sobrepõe-se a esses sedimentos, camada de $1 \mathrm{~m}$ de areia argilosa cinza, coberta por aterro.

As análises de difratogramas de Raios X indicaram a presença de caulinita, quartzo e mica na amostra total, sendo que na fração argila verificou-se a presença predominante da caulinita, $o$ que mostra que a mica encontra-se nas porções mais grossas desse sedimento. As imagens obtidas no MEV exibem caulinitas em placas com bordas irregulares (Fotografia 47).

Deve-se ressaltar a importância da camada de argila orgânica presente nos depósitos aluviais quaternários. Essa camada embora apresente idades variando entre $32.480+/ .330$ anos $400+/-50$ anos AP, apresenta-se mais desenvolvida na passagem Holoceno-Pleistoceno. 


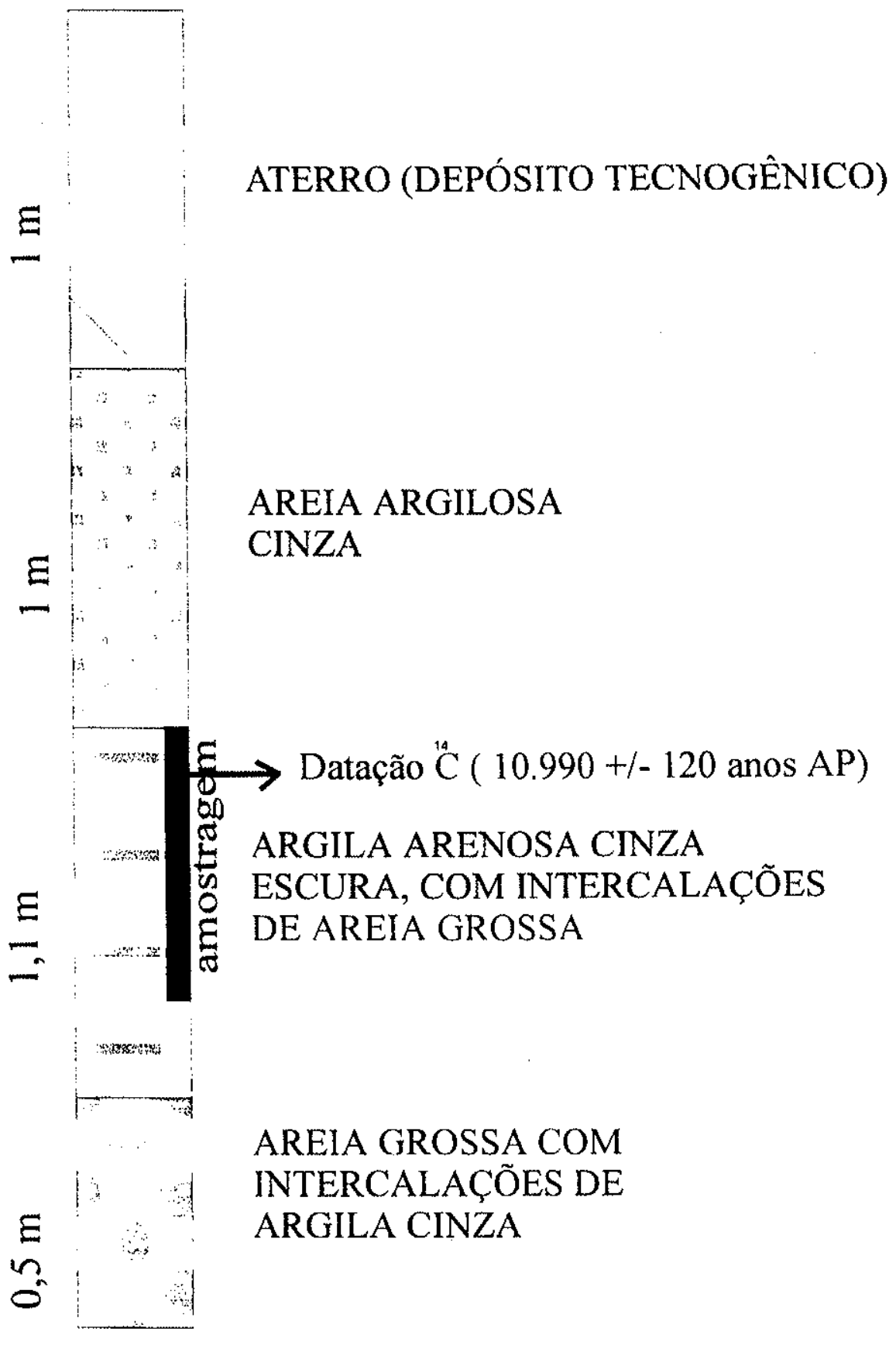

Figura 16 - Perfil de sedimentos quaternários situados próximo ao Córrego Morro do S, Campo Limpo. 


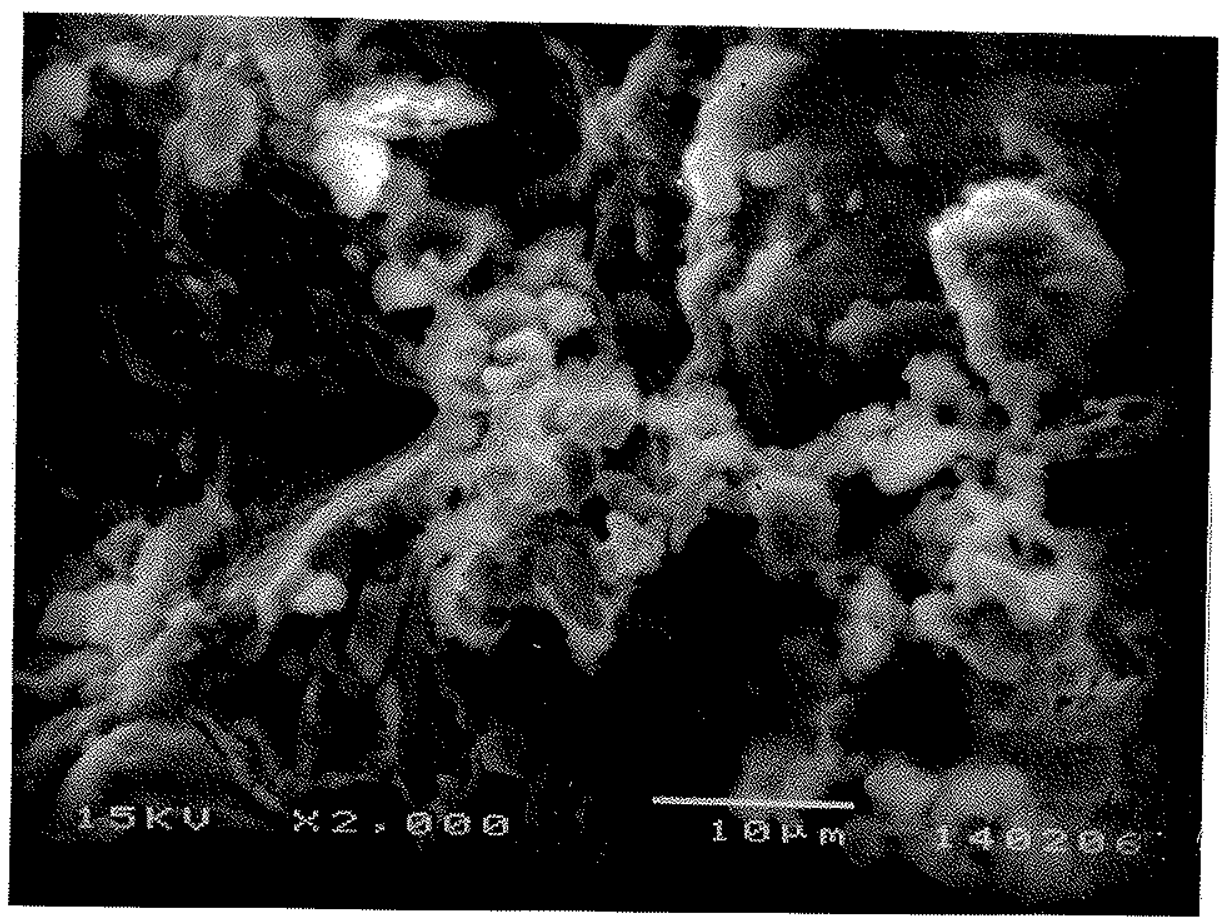

Fotografia 47. Caulinitas em placas com bordas irregulares. Amostra H-AL-04. Córrego Morro do S, Campo Limpo. 


\subsubsection{DATAÇÕES RADIOCARBONO 14C E ANÁLISES PALINOLÓGICAS.}

\subsubsection{CONSIDERAÇÕES GERAIS}

Foram realizados neste estudo 21 datações ${ }^{14} \mathrm{C}$ executadas pelo Laboratório Beta Analitic, Miami, Flórida, EUA (Tabela 1).

À exceção de quatro amostras constituidas por fragmentos de carvão, o restante do material datado correspondia a sedimentos argilosos a arenosos orgânicos, de coloração cinza a preta, coletadas em planícies aluviais situadas próximas às atuais drenagens.

Efetuou-se análises palinológicas em 10 locais de amostragem (Tabela 1), sendo que em 3 deles (H-MS, H-PCB e ORAT) coletou-se amostras contínuas, processadas em intervalos de 10 em $10 \mathrm{~cm}$. As amostras H-AL-1, H-AL-2, H-AL-11, e H-AL-13 mostraram-se praticamente estéreis. A amostra ORAT foi reprocessada como uma única amostra, por apresentar pequena quantidade de material polínico.

Deve-se mencionar ainda que a amostra H-PCB (contínua), na qual foram efetuadas 3 datações foi desconsiderada, pois apresentou inversão de idades, devido provavelmente, a contaminação das amostras coletadas. Nova amostra representativa da camada analisada foi coletada, submetida a datação e análise palinológica, cujos resultados são discutidos a seguir.

\subsubsection{ANÁLISE DOS DADOS OBTIDOS}

As idades obtidas refletem principalmente a passagem Pleistoceno-Holoceno $(12.890+/-70$ anos AP - H-AL-1; 10.990 +/- 120 anos AP - H-MS; 10.970 +/. 100 anos AP H-AL-2; 10.220 t/80 anos AP - H-AL-23), mostrando que nessa época havia franco desenvolvimento das planícies meandrantes, em condições que apresentariam altos índices pluviométricos (alta taxa de umidade).

MOURA et al (1993) e MELLO et al. (1995) sugerem para a área do médio vale do rio Paraíba do Sul condições climáticas úmidas no início do Holoceno, associadas a instalação de cobertura florestal.

A análise palinológica efetuada na amostra H-MS (Figura 16) exibe a partir de $20 \mathrm{~cm}$ uma maior frequêencia de pólens de plantas arbóreas como Moraceae-Urticaceae, Apocynaceae, Mimosaceae, Palmae (Figuras 17 e 18). A idade de $10.990+/-120$ anos AP foi obtida para essa 
mesma amostra, a 10-20 cm de profundidade (Figura 16), o que indica que as condições climáticas úmidas teriam persistido, provavelmente, desde épocas um pouco mais antigas.

A análise da amostra H-MS indicou ainda predominância de pólens de Poaceae (Gramineae) em todo o perfil estudado, representando um ambiente aberto. As Asteraceae (Compostas) são bem representadas em todo o perfil, principalmente na base. As Cyperaceae encontram-se entre 50 e $5 \mathrm{~cm}$, sendo mais abundantes entre 22 e $5 \mathrm{~cm}$. Neste intervalo foram encontrados também, algas dos tipos tipos Zygnema e Debarya indicando que o local estaria inundado por águas rasas (Figuras 18 e 19).

Foi efetuado o estudo palinológico integrado das amostras ORAT, H-AL-19, PCB e H-AL24 (Tabela 1) a partir da contagem sistemática de pelo menos 200 grãos de palinomorfos obtidos na análise de diversas lâminas, uma vez que o material polínico encontrado é bastante escasso. As datações das amostras citadas forneceram respectivamente as idades 32.480 +/- 330 anos AP; 30.170 +/- 270 anos AP; 8120 +/- 90 anos AP; 4010 +/- 60 anos AP, indicando diferentes fases paleoclimáticas, algumas identificadas também em trabalhos efetuados por diferentes autores na região Sudeste e Central do Brasil, comentadas a seguir. 

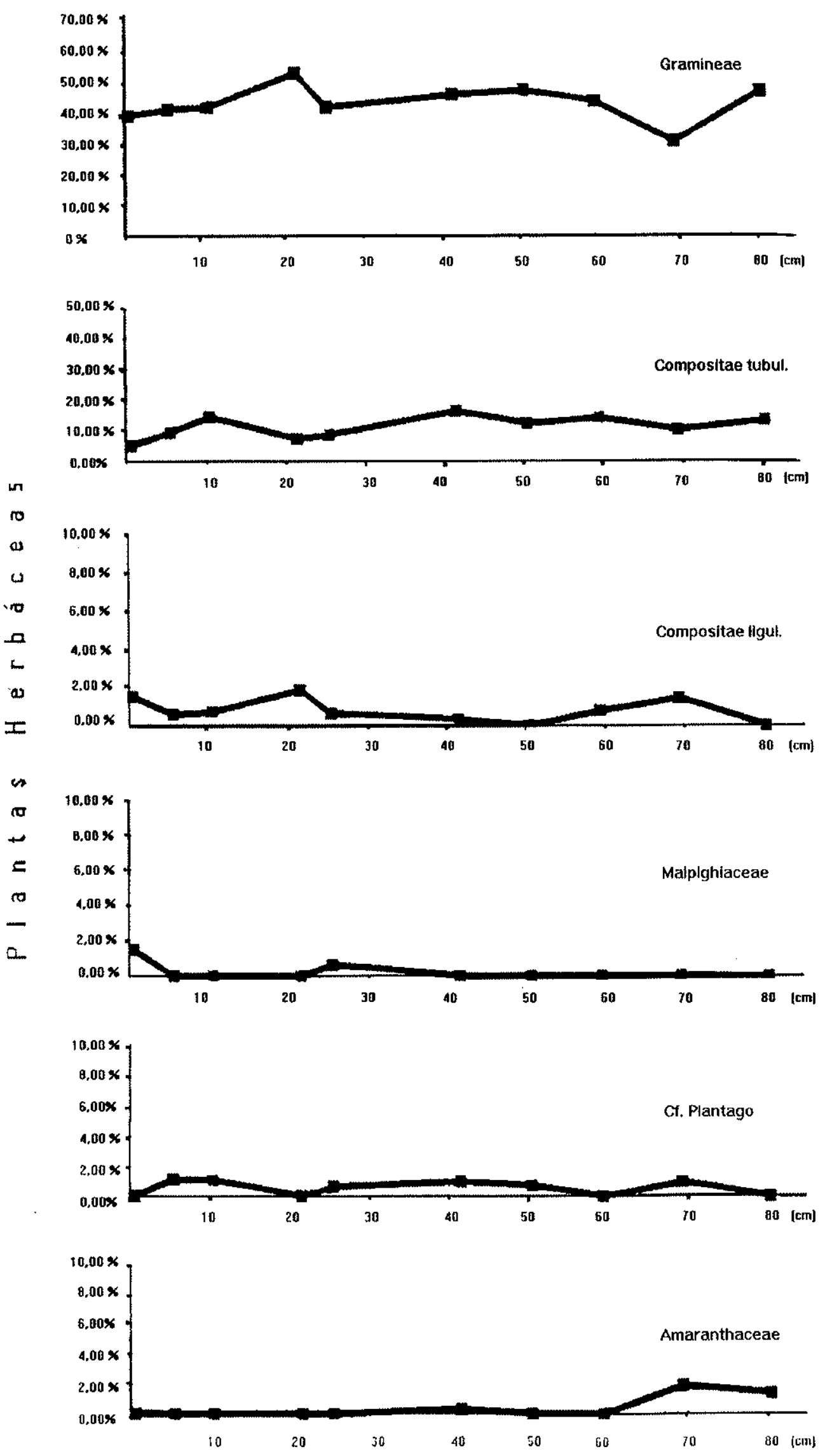

Figura 17. Porcentagens de tipos polínicos presentes na amostra H-MS, Campo Limpo. 

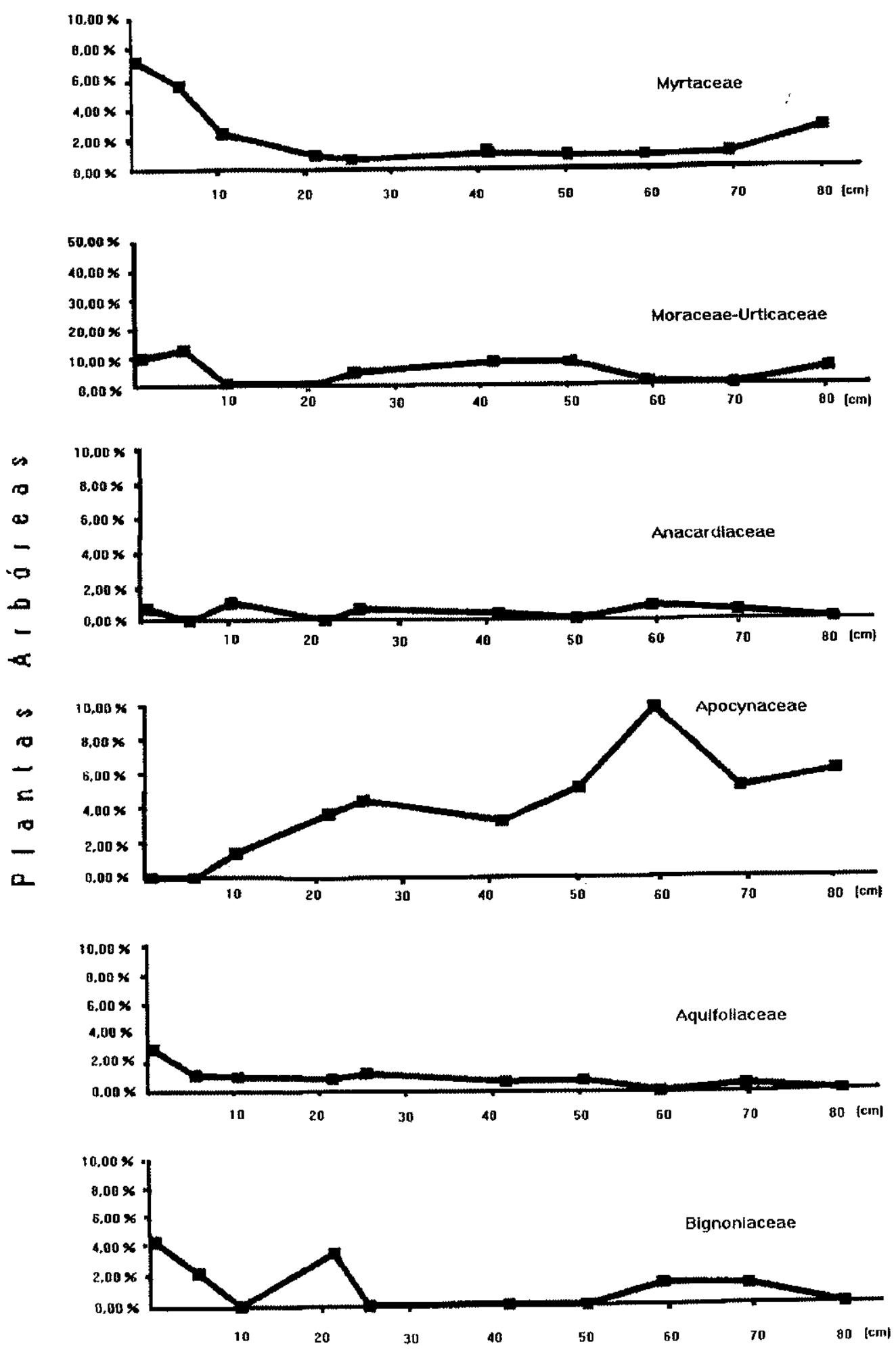

Figura 18. Porcentagens de tipos polínicos presentes na amostra H-MS, Campo Limpo. 

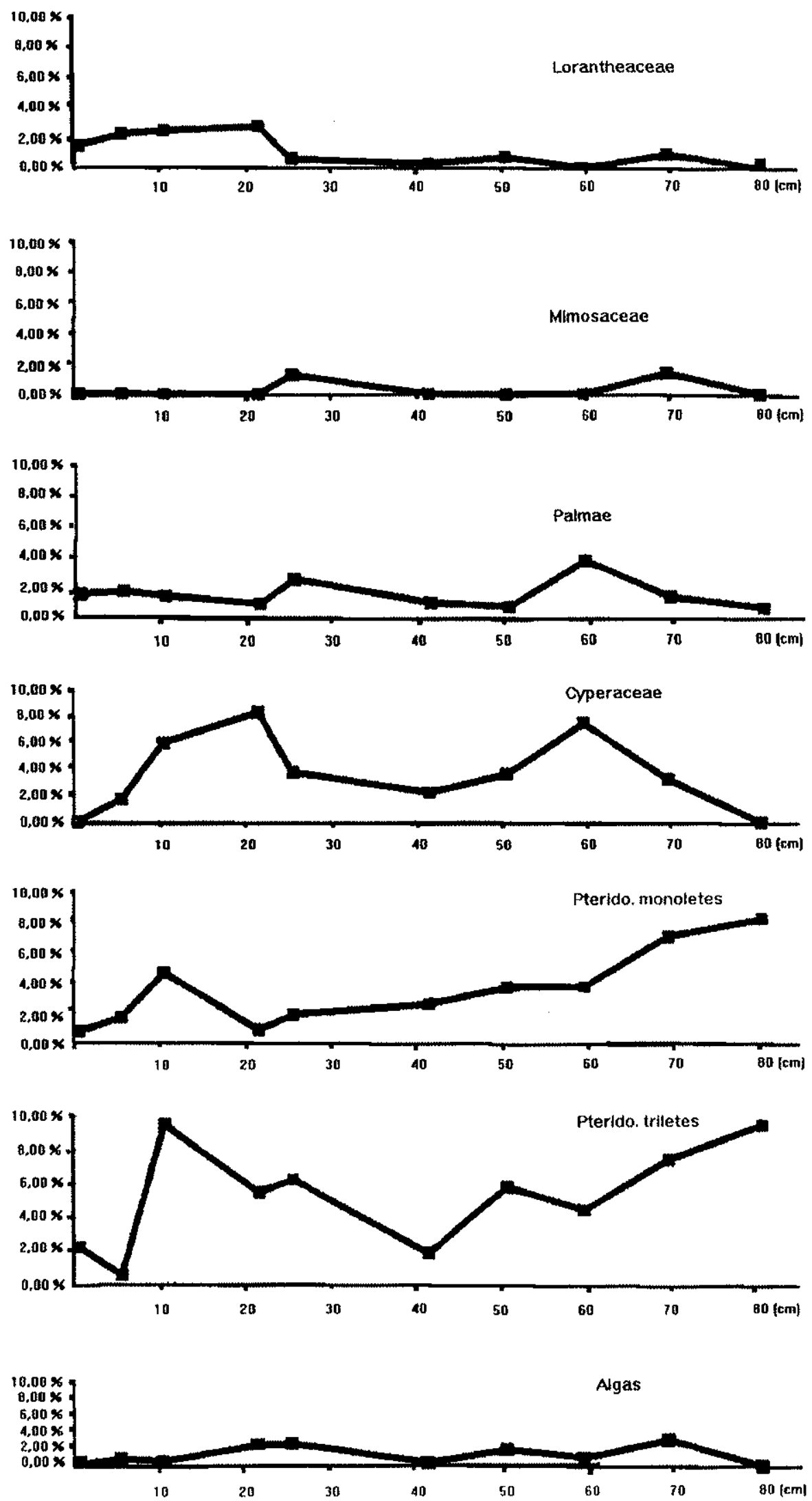

Figura 19. Porcentagens de tipos polínicos presentes na amostra H-MS, Campo Limpo. 


\section{Figura 20. Diagrama polínico de porcentagem}

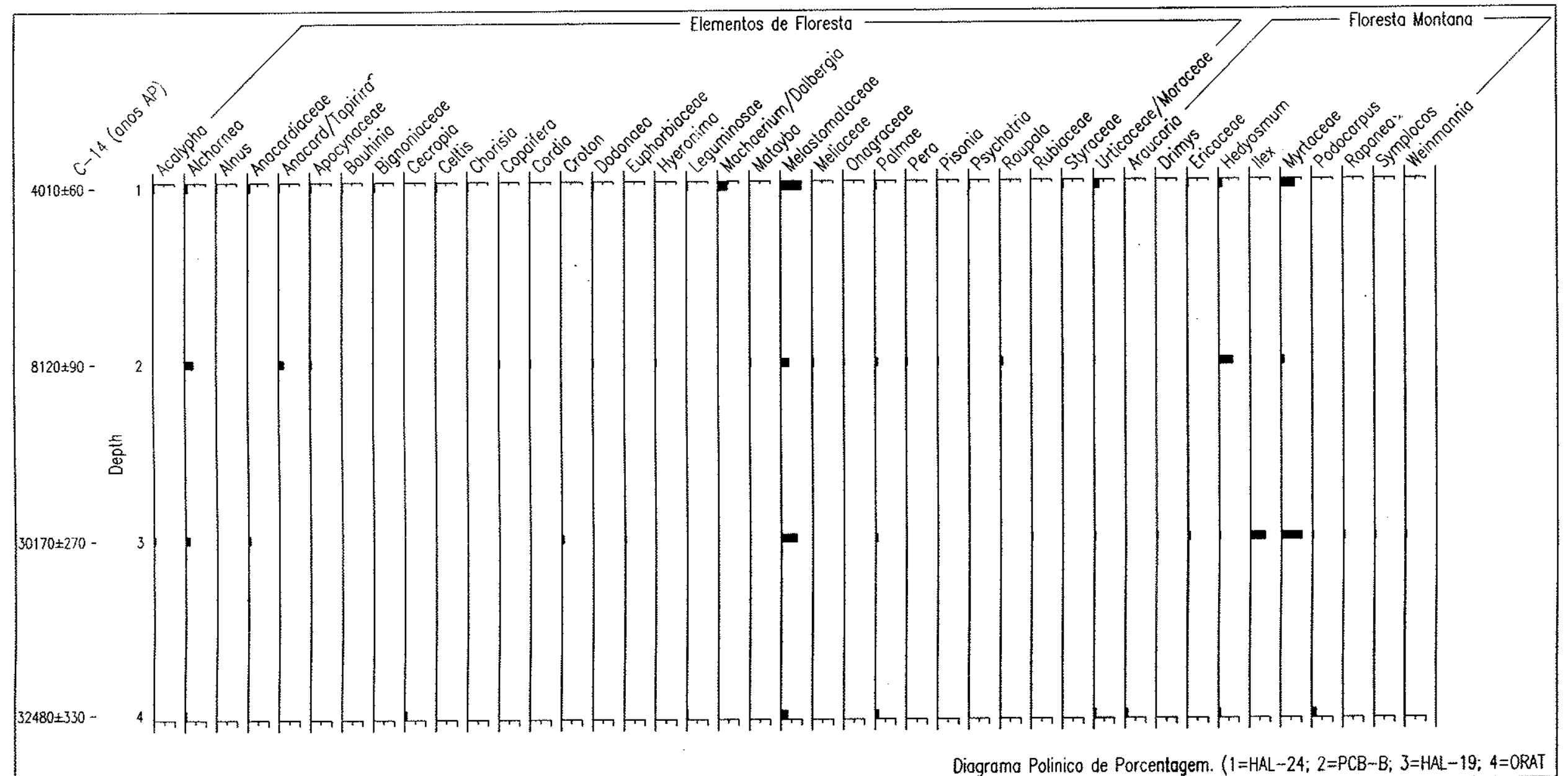


Figura 21. Diagrama polínico de porcentagem

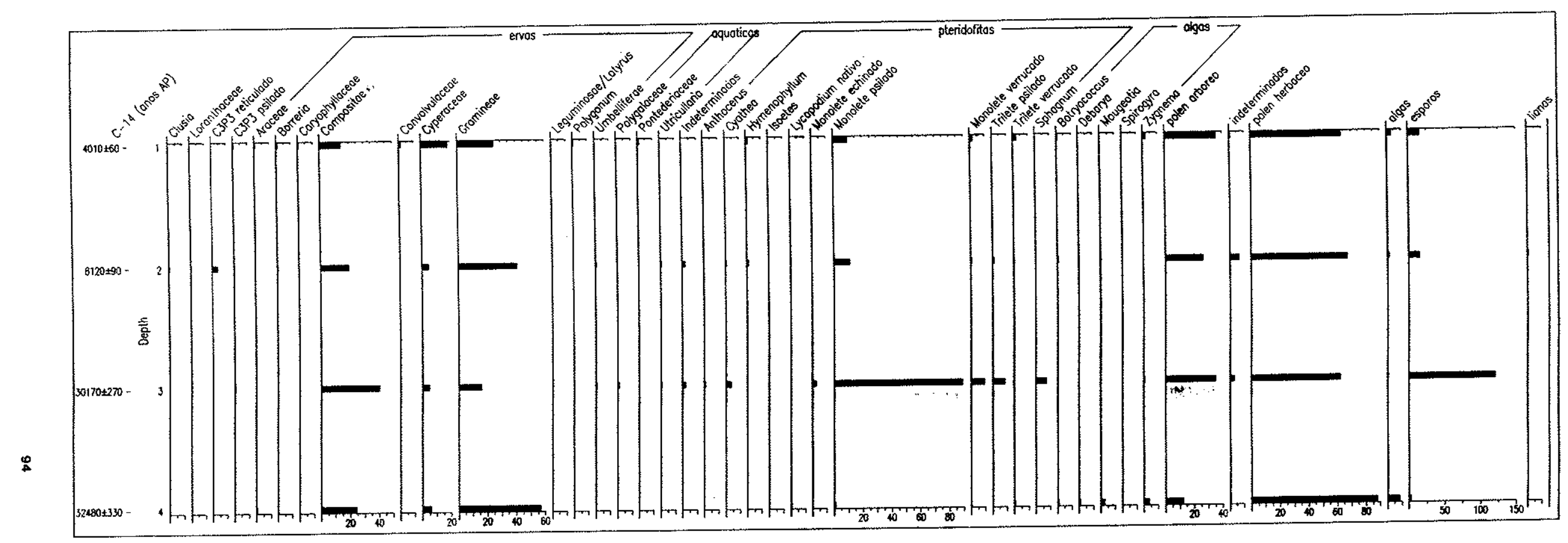


Figura 22. Diagrama de concentração

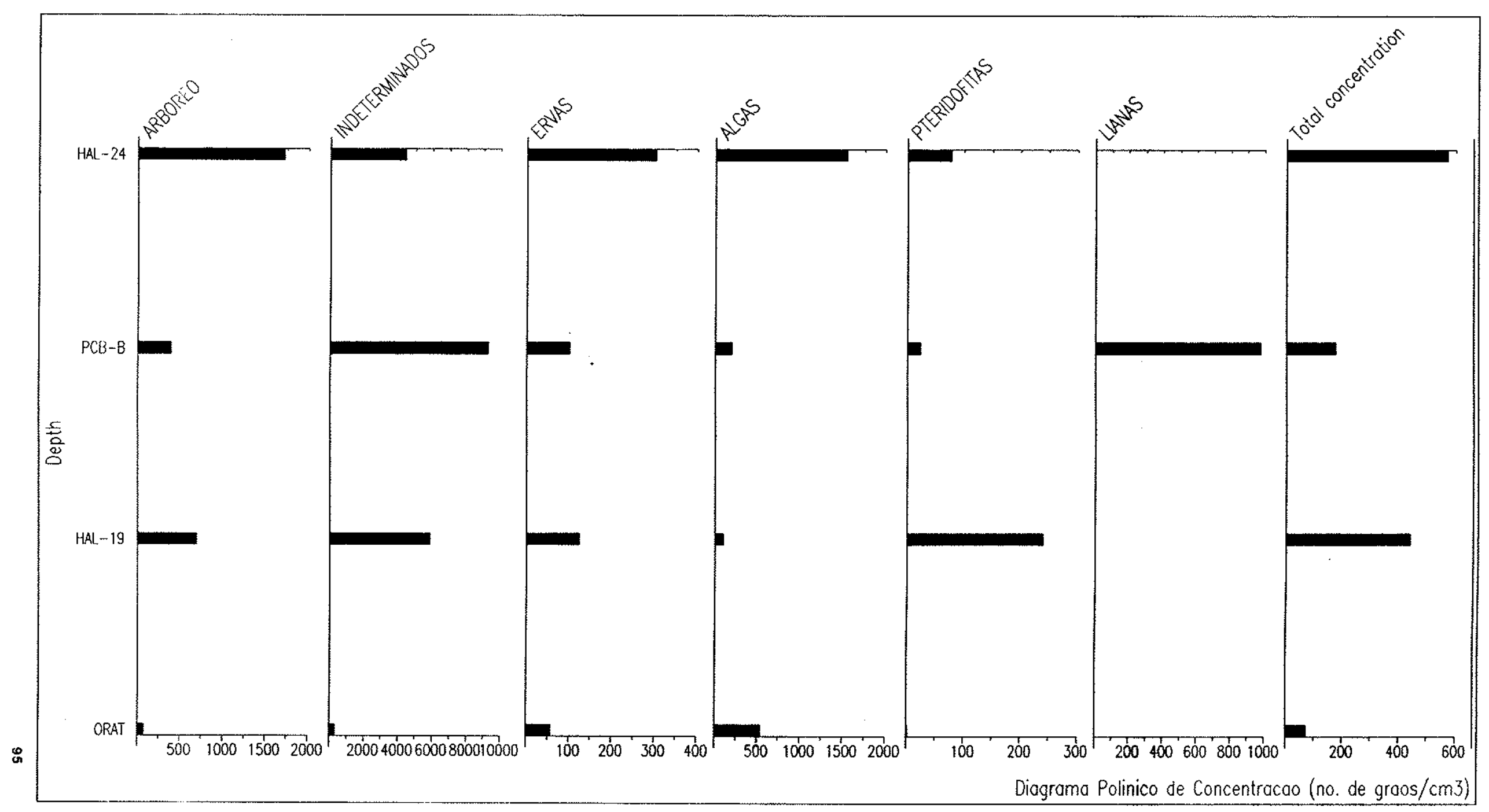


Os elementos de floresta montana são mais abundantes nas amostras pleistocênicas onde destaca-se a presença de Araucaria (a 32.480 +/- 330 anos AP), Podocarpus (a 32.480 +/- 330 anos AP, e a 30.170 +/. 270 anos AP), Ilex, Myrtaceae, Drimys, Ericaceae, Rapanea, Symplocos e Weinmannia ( a 30.170 +/-270 anos AP, Figura 20), o que indicaria estações de baixa temperatura, provavelmente associados a condições climáticas úmidas a $32.480+/-330$ anos AP.

A $30.170+/-270$ anos AP nota-se indices maiores de concentração de palinomorfos, indicando condições mais favoráveis a instalação de vegetação, com predomínio de esporos de pteridófitas (Figura 22), que apresentaram alta porcentagem ( $>85 \%$ ). A presença de elementos de floresta montana, comentadas anteriomente, indicariam ainda para essa época condições de baixas temperaturas, úmidas, devido à presença marcante de pteridófitas.

Deve-se mencionar entretanto, que a baixa concentração de pólens em geral, notadamente os arbóreos, e a alta porcentagem de palinomorfos de ervas (Figuras 21 e 22, amostras ORAT e H. AL-19) dentro do contexto mencionado, poderiam indicar condições de clima seco subordinadas.

O estudo efetuado por LEDRU (1991), em Salitre, MG, mostra no intervalo de $32.030+$ 2020/- 1620 anos AP e $28740+1970 /-1580$ a freqüência dos mesmos elementos de floresta montana encontrados neste trabalho para 32.480 +/- 330 anos AP e a 30.170 \% 270 anos AP, quais sejam: Araucaria, Podocarpus, Myrtaceae e Ilex. A autora sugere para o intervalo citado condições quentes e úmidas.

A amostra PCB datada em $8.120+/-90$ anos AP mostra uma alta concentração de palinomorfos indeterminados, os quais apresentam-se comumente oxidados. Verifica-se novamente nessa época, uma diminuição da concentração geral de palinomorfos (Figura 22), ressaltando-se, no entanto, altas porcentagens (cerca de 70\%) de ervas (Gramineae, Compositae e Cyperaceae) associados a índices médios de concentração das mesmas. Nota-se ainda grande variedade de elementos arbóreos, inclusive de floresta montana (Hedyosmum, Myrstaceae e llex), apesar de representarem cerca de $30 \%$ do material analisado.

A análise palinológica da amostra PCB sugere para o início do Holoceno a implantação de condições climáticas mais secas que as observadas na passagem Holoceno- Pleistoceno, porém em ambiente possivel de desenvolvimento de florestas restritas. O baixo índice de concentração de pólens, o predomínio de elementos herbáceos aliados a presença de palinomorfos oxidados que 
poderiam representar índícios de fogueiras, justificariam a hipótese aqui apresentada da existência de clima seco na região estudada há aproximadamente 8.000 anos AP.

GARCIA (1994), através de estudos palinológicos efetuados no Vale do Paraíba, descreve condições climáticas secas e quentes com precipitação intensa e irregular há $8100+/-100$ anos AP (Jacareí) e há $8250+/-90$ anos AP (Taubaté). Condições climáticas secas associadas a queimadas naturais (fogo) na região de Salitre são registradas por OLIVEIRA (1992) há cerca de 7500 anos AP.

MELLO et al. (1995) sugere a implantação de condições climáticas secas associadas a chuvas concentradas de alta intensidade na deposição da Aloformação Manso, cuja sequência basal indicou idades entre 8.800 a 8.500 anos AP.

A amostra H-AL-24 (4.010 +/- 60 anos AP) por sua vez, apresentou altos índices de concentração de palinomorfos, predominantemente arbóreos, os quais exibiram relativa variedade de gêneros, com elementos de mata bem representados com taxa de cerca de $35 \%$ (Figuras 20 e 21). Os elementos herbáceos (Gramineae, Cyperaceae, Compositae e Convolvulaceae) têm ocorrência significativa na amostra, indicando índices de $65 \%$ e aproximadamente 300 grãos $/ \mathrm{cm} 3$ de concentração, sendo este, o maior índice verificado em comparação com as outras amostras analisadas (Figura 22). Houve também condições de desenvolvimento de florestas de altitude restritas ou pouco restritas, devido a presença de Hedyosmum e Myrtaceae.

$\mathrm{O}$ espectro polínico da amostra H-AL-24 sugere para a região em estudo a presença de vegetação mista, já descrita para a região leste e sul do Brasil (HUECK 1965). Os elementos de mata bem representados sugerem condições úmidas, provavelmente próximas das atuais.

OLIVEIRA (1992) registrou em estudo efetuado em sedimentos coletados na Lagoa dos Olhos, na região do Triângulo Mineiro, a presença de alta taxa de porcentagem e concentração de Gramineae no intervalo situado acima de $6.790+/-140$ anos AP e um pouco mais antigo que 2.760 +/- 70 anos AP. Há 4.000 anos descreve elevação da umidade devido a presença de Hedyosmum e Myrtaceae.

LEDRU (1991) descreve a ocorrência de floresta aberta com extrato herbáceo bem desenvolvido apresentando cerca de $80 \%$ de Gramineae e elementos arbóreos, no periodo compreendido entre $4.350+540 /-500$ anos AP e $3.060+/-210$ anos AP. A interpretação 
paleoambiental dada pela autora para a região de Salitre é a presença floresta estacional semidecídua com estação seca curta (1 a 2 meses). (LEDRU 1993).

Deve-se mencionar a presença de aumento de umidade na região sul do Brasil em períodos anteriores a 3900 - 3600 anos AP, referíveis a situação de bloqueio de frentes polares devido a condições de Paleo EI Niño (MARTIN et al. 1992) que poderiam estar associados ao período mais úmido identificado na área de estudo.

Foram ainda efetuadas datações de sedimentos argilosos orgânicos situados próximos a atuais drenagens na Zona Oeste (H-AL-11, H-AL 13), Sul (H-MS, H-TR-1), e Leste (H-AL-18, HAL-20) (Tabela 1), que forneceram respectivamente as seguintes idades: $6.020+/-70$ anos AP; 3.080 +/- 70 anos AP obtidas em um mesmo perfil, com $90 \mathrm{~cm}$ de distância entre as amostras; 400 +/-50 anos AP; $2110+/-60$ anos AP; 18.940 +/- 110 anos AP; e 27.480 +/- 280 anos AP.

A partir dos dados obtidos no presente trabalho sugere-se duas fases principais de desenvolvimento de rios meandrantes na área de estudo. A primeira com idade entre $32.480+/-330$ anos AP a 18.940 +/- 110 anos AP; e a segunda situada na passagem Pleistoceno - Holoceno até épocas atuais.

Essas fases praticamente coincidem com aquelas definidas por TURQ et al (1993) que indicam dois eventos marcados por deposição de matéria orgânica no Brasil Central, o primeiro entre 32.000 e 19.000 anos AP, e o segundo entre 10.000 anos AP e o presente, melhor caracterizado entre 6.000 e 4.000 anos AP, mostrando que o desenvolvimento de planícies aluviais nos períodos citados teve expressão regional, abrangendo áreas significativas do pais.

Para a região de São Paulo, AB'SABER (1980) descreve um ciclo de deposição fluvial das denominadas camadas cruzadas da fase Butantã, há cerca de 40.000-50.000 anos AP, seguido de nova deposição aluvial, iniciada segundo o autor, há aproximadamente 8.000 a 10.000 anos AP.

Quanto as condições paleoclimáticas reinantes nas duas fases propostas, correlaciona-se a primeira a condições climáticas mais frias e úmidas pelo menos para ínicio do período.

LEDRU (1991) e OLIVEIRA (1992) identificam para a região do Triângulo Mineiro, durante o máximo glacial a ação da Frente Polar Atlântica, refletindo em baixas temperaturas e maiores índices de umidade. É provável que a frente fria tenha tido influência na região estudada, no entanto TURCQ et al. 1996 sugerem, pelo menos para o início do Holoceno, padrão distinto de circulação de frentes frias, que seguiriam uma tragetória mais interiorana. 
A segunda fase de desenvolvimento de planícies aluviais na região teria idade essencialmente holocênica, sendo bem marcada durante a passagem Pleistoceno - Holoceno. A camada argilosa orgânica encontrada nessas planicies poderia ser considerada como um marco da sedimentação holocênica na região estudada.

Em relação às variações paleoclimáticas ocorridas nessa fase, regionalmente, alguns autores identificaram episódios de clima seco há 6.000, 4.000, 2.000 anos AP, (SERVANT et al. 1989), e há 1.000 e 300 anos AP (RICCOMINI et al. 1991a). TAKIYA \& YBERT (1991) através de análise palinológica de sedimentos argilosos orgânicos situados no Vale do Anhangabaú, sugeriram a existência de fase de clima seco há $4732+1-60$ anos AP na região central do município.

Verifica-se ao analisar os trabalhos citados, a existência de fases secas a cada 2.000 anos ou menos, a partir de 2.000 anos AP. A correlação entre os dados existentes é ainda precária devido a quantidade de informações (datações, análises palinológicas) ser ainda insuficiente para distinção de fases secas com expressão regional daquelas mais localizadas. No entanto, considera-se que a fase seca identificada há cerca de 8.000 anos AP tenha ocorrência mais ampla, abrangendo inclusive a região do Vale do Paraíba.

\subsection{DEPRESSÃO CIRCULAR DE COLÔNIA}

A depressão circular de Colônia apresenta cerca de $3,64 \mathrm{Km}$ de diâmetro e localiza-se no extremo sul do município de São Paulo (Anexo A, Figura 23).

Alguns autores como KOLLERT et al. (1961) e CROSTA (1982) sugerem que esta depressão circular corresponda a uma provável estrutura de impacto de corpo celeste ou astroblema, com idade entre $36 \mathrm{Ma}$ e 5,2 Ma (RICCOMINI et al. 1989).

Esta pequena bacia de deposição revela um preenchimento de cerca de $263 \mathrm{~m}$ de sedimentos ricos em matéria orgânica. Sondagem com $8,78 \mathrm{~m}$ de profundidade, executada no interior da estrutura circular, exibiu sedimentos predominantemente argilosos, de coloração preta, com restos de plantas ao longo de todo o testemunho (RICCOMINI et al. 1989).

As análises palinológicas executadas por LORSCHEITTER et al. (1990) indicaram condições climáticas frias e úmidas abaixo do nível arenoso, a $2,73 \mathrm{~m}$ de profundidade, cuja idade por datação ${ }^{14} \mathrm{C}$ revelou 28.080 anos AP. Acima desse nível, o conteúdo polínico apontou vegetação campestre de clima mais seco há 28180,21500, 18100 anos AP respectivamente a 226 
$\mathrm{cm}, 106 \mathrm{~cm}, 46 \mathrm{~cm}$.. A idade mais jovem registrada, 18.180 anos AP, mostrou não haver registro holocênico no local (RICCOMINI et al. 1989).

Novas datações realizadas em amostras desse mesmo perfil, a aproximadamente $3 \mathrm{~m}$ de profundidade, revelaram idades em torno de 52.000 anos AP (TURCQ, informação pessoal).

Os cálculos teóricos executados por RICCOMINI et al. (1989) e estudos geofísicos recentes (MASERO \& FONTES 1991) sugerem, para a estrutura, profundidade maior que $400 \mathrm{~m}$, denotando que abaixo dos $263 \mathrm{~m}$ de sedimentos, possa ocorrer um pacote de depósitos fanglomeráticos com fragmentos de rochas do embasamento (RICCOMINI \& COIMBRA in NEGRO Jr et al. 1992).
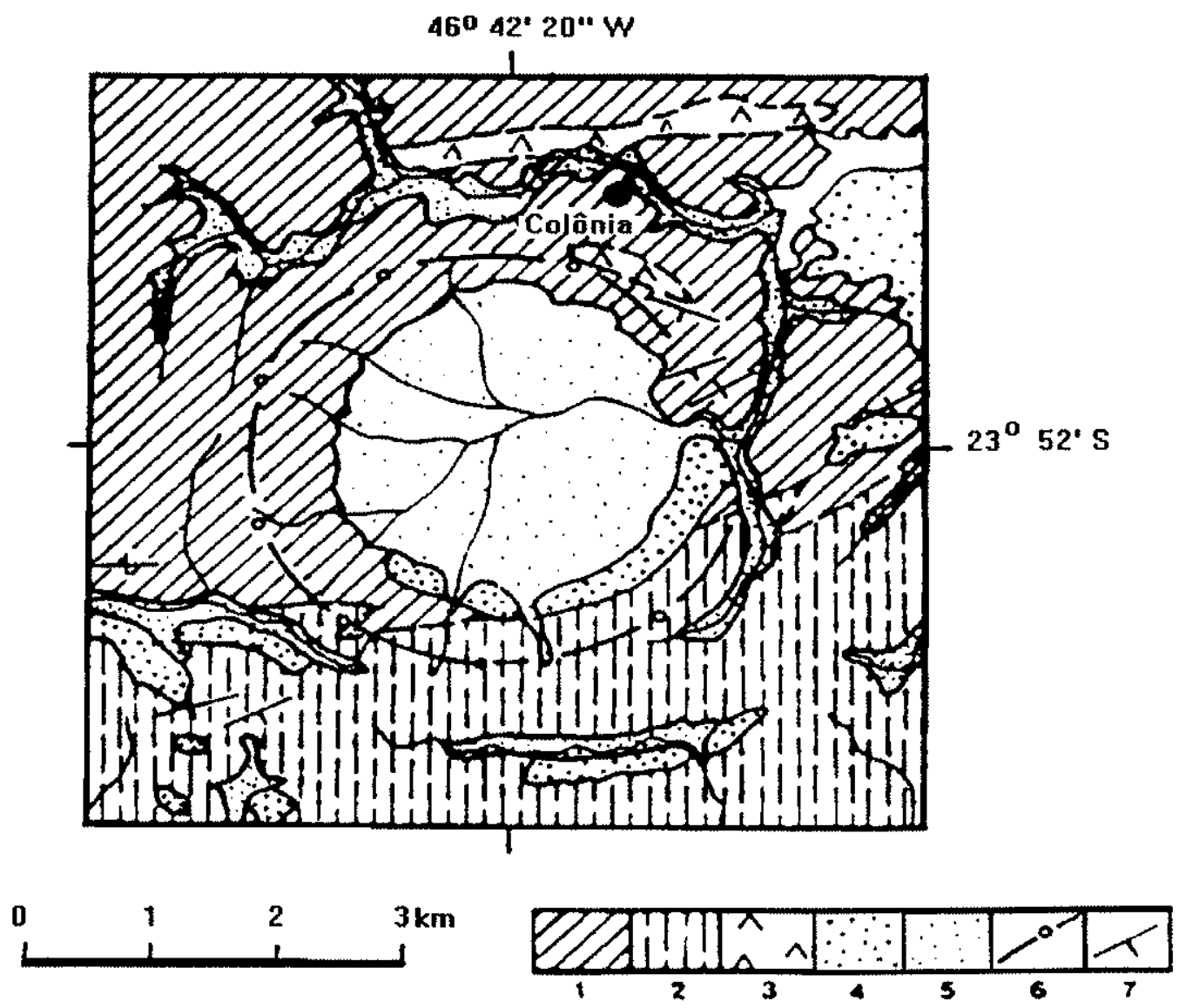
Figura 23. Geologia da área do Astroblema de Colônia (COUTINHO, 1980, modificado; RICCOMINI et al. 1991b). 1. micaxistos, milonitos; gnaisses, migmatitos, localmente milonitos; 3 . dioritos e quartzo dioritos; 4. sedimentos terciários; 5 . depósitos aluviais quaternários; 6. anel circular externo; 7. orientação geral das estruturas do embasamento.

Cabe mencionar que a área do astroblema de Colônia foi recentemente tombada pelo Conselho de Defesa do Patrimônio Histórico, Arqueológico, Artístico e Turístico do Estado CONDEPHAAT, em sua Sessão ordinária, realizada em 5 de Junho de 1995. No âmbito municipal o processo de tombamento encontra-se em apreciação no Conselho Municipal de Preservação do Patrimônio Histórico, Cultural e Ambiental da Cidade de São Paulo - CONPRESP, com manifestação favorável da Secretaria Municipal do Verde e Meio Ambiente.

Entretanto deve-se mencionar que a área do astroblema encontra-se atualmente ocupada, principalmente em seu setor sul, por loteamento clandestino ( Fotografia 48) pertencente a União dos Favelados do Grajaú - UNIFAG. A região é ainda ocupada por um presídio estadual (Fotografia 48). 


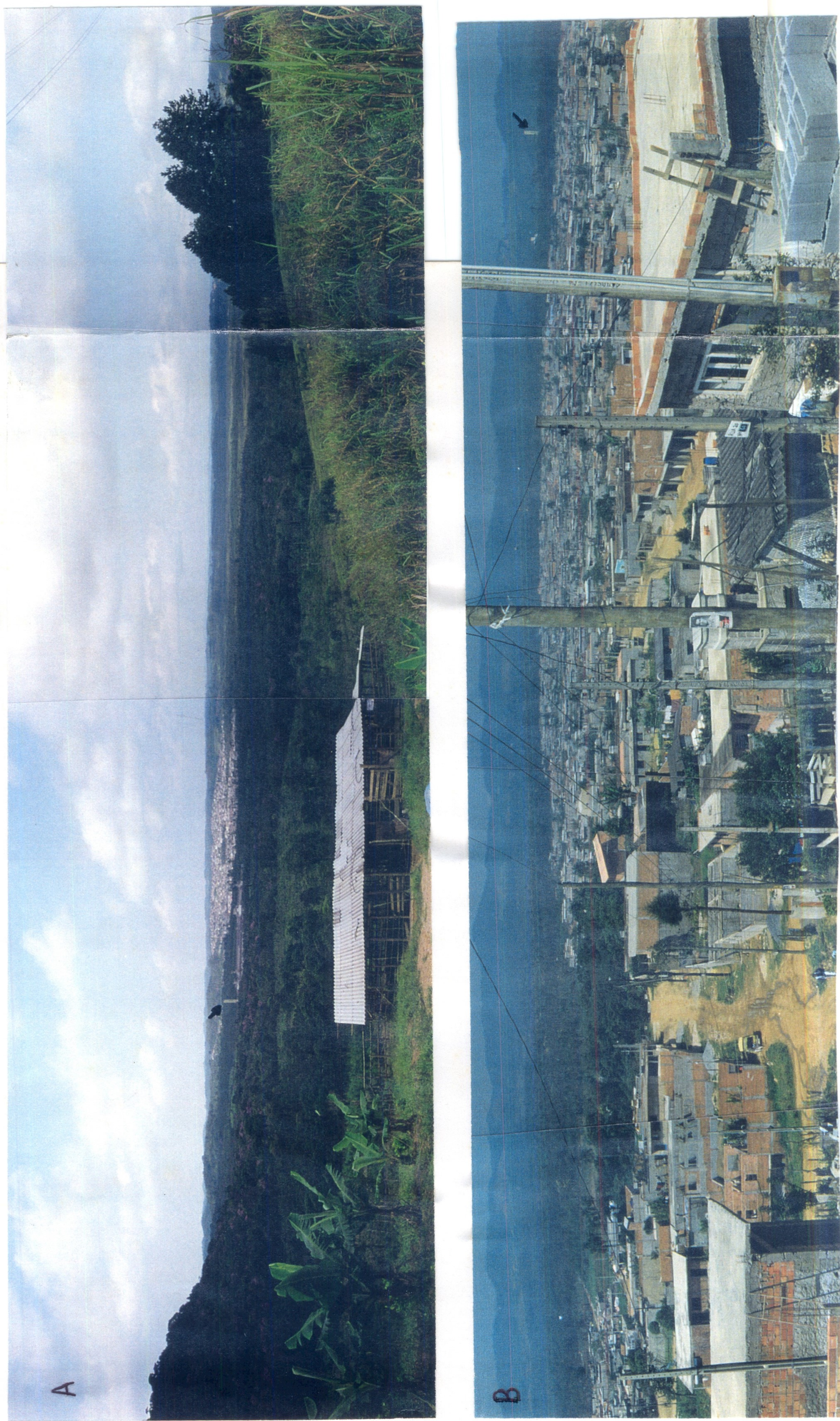

Fotografia 48. Vista geral do Astroblema de Colônia. A seta indica a torre do presídio estadual.

A- Tomada de sul para norte. Foto cedida pelo Geólogo Vitor Cesar Nishimoto.

B- Tomada de norte para sul, destacando a ocupação desordenada. Foto cedida pelo Arquiteto Carlos Christiano A. Ramsthaler. 


\subsection{SÍNTESE}

O desenvolvimento de planícies aluviais na área estudada é registrada neste estudo a partir do início do Pleistoceno, há 32.480 +/ 330 anos AP persistindo até a atualidade, sendo a idade mais recente obtida de $400+/-50$ anos AP.

Os dados obtidos no presente trabalho permitem sugerir duas fases principais de desenvolvimento de rios meandrantes na área de estudo. A primeira situada no intervalo de 32.480 +/- 330 anos AP - 18.940 +/- 110 anos AP e a segunda relacionada aos depósitos datados desde a passagem Pleistoceno - Holoceno até épocas atuais, de maior expressão em termos de extensão de suas planícies aluviais (Figura 24).

Quanto as fases de coluvionamento foi possível identificar três eventos sucessivos, embora o último deles tenha provaveimente caráter local. As datações efetuadas em fragmentos de carvões situados no topo dos depósitos coluviais apontaram idades de $610+/-80$ anos AP e $3000+/-140$ anos AP, sendo essa última, referente a fase principal de coluvionamento ocorrida na área de estudos (Figura 24).

O registro mais antigo do quaternário na área de estudo $(32.480+/-330$ anos AP) refere-se ao último glacial (Estádio Würn), e relaciona-se ao desenvolvimento de coberturas aluviais pleistocênicas em clima úmido e frio, com presença de florestas montanas (de altitude) ricas em Araucária, Podocarpus, llex, Myrtaceae entre outros, ocorrendo subordinadamente, campos com predomínio de elementos herbáceos como Gramineae, Compositeae e Cyperaceae. As planícies aluviais dessa primeira fase desenvolvem-se até cerca de 19.000 anos. Embora não datada, não descarta-se a possibilidade de ocorrência de uma fase antiga de coluvionamento nesse periodo (32.000 a 18.000 anos AP, Figura 24). No extremo Sul do município, na estrutura circular de Colônia, são registradas idades de 52.000 (TURCQ, informação pessoal), e condições climáticas secas após 28.180 anos AP (LORSCHEITTTER et al. 1990).

A segunda fase de ocorrência de planícies aluviais na área inicia-se provavelmente na passagem Pleistoceno/Holoceno, quando imperavam condições climáticas úmidas e presença de florestas. Há cerca de 8.000 anos AP é registrado na área de estudos a presença de ambiente seco, com florestas restrita. A deposição fluvial meandrante tornam-se mais argilosa, com predomínio de argilas cauliníticas, a partir de 6.000 anos, com desenvolvimento intenso de meandros abandonados e amplas planícies aluviais. Há aproximadamente 4.000 anos AP verifica-se a ocorrência de clima mais úmido, próximo do atual em ambiente de florestas bem desenvolvidas coexistindo com 
R. Borges Figueiredo

Zona Leste.

0 एर

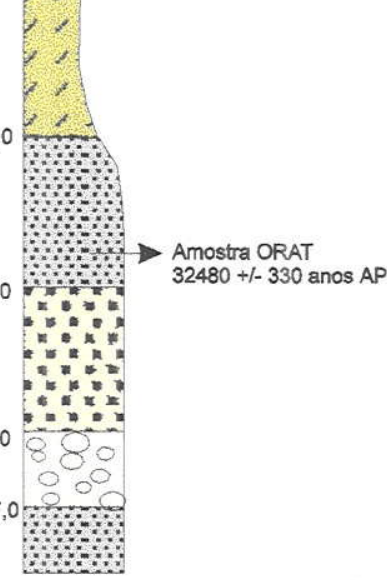

AV. Waldemar Ferreira, Butantā, Zona Oeste.

$0=$

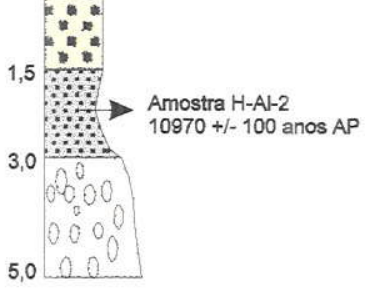

AV. Săo Miguel

Córrego Franquinho

$0,5,4,4$

Amostra H-Al-23
$10220+1-80$ anos

úmido, próximo do atual com elementos de $4010+/-60$ mata bem representado com alto

índice de pólens de ervas.

seco ambiente aberto (pólens de ervas) e $\quad 8120+1-90$ floresta restrita

úmido com elementos arbóreos

$0990+/-120$

anos $A P$

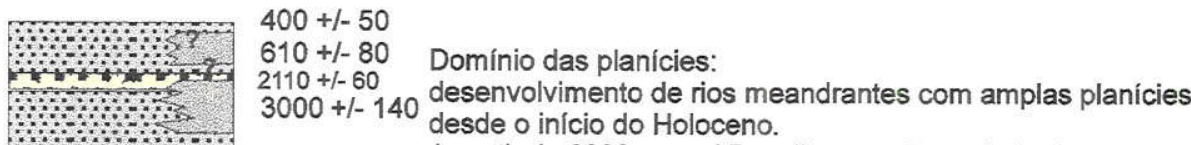

A partir de 6000 anos AP sedimentação orgânica intensa.

$6020+/-70$ Domínio das encostas:

coluvionamento intenso há cerca de 3000 anos AP podendo ter início a 4000 anos AP. (fase principal). A fase mais recente de coluvionamento ocorreu há 610 anos AP.

$10220+1-80,10970+1-100$

$12890+1-70$
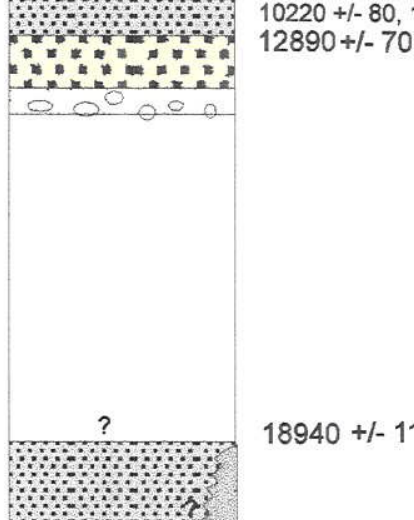

$18940+/-110$

úmido e frio

floresta montana

$30170+/-270$

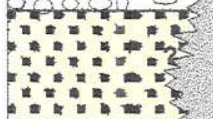

है

$27480+1-280$

Planicies aluviais

(primeira fase) associada a provável coluvionamento nas costas.
Figura 24. Correlação entre a sedimentação quaternária no Município de São Paulo, idades, paleoclimas e paleovegetação.
Aterro 7 Argila

Colúvio " Areia

\section{Conglomerado}


campos com predomínio de elementos herbáceos. Nessa época (passagem de clima seco para úmido) provavelmente iniciou-se a deposição da fase principal de colúvios, no domínio das encostas. Ainda nesse domínio, registra-se uma fase de coluvionamento recente, há cerca de 610 anos AP principalmente na Zona Sul do município. O ciclo da deposição aluvial apresenta um último registro bastante recente, há 400 anos AP. (Figura 24).

\subsection{COMPORTAMENTO GEOTÉCNICO}

Os depósitos quaternários podem ser reconhecidos em sondagens pela sua baixa resistência a penetração (indices SPT - Standart Penetration Test na maioria das vezes abaixo de 3) devido a baixa compacidade e consistência dos mesmos.

Os depósitos aluviais quaternários são relativamente bem conhecidos na geologia de engenharia, identificados como solos hidromórficos, sendo que o maior problema a eles associado é o recalque causado em fundações e aterros, devido fundamentalmente a presença da camada de argila orgânica, característica desses depósitos. Esses depósitos podem causar ainda, dificuldades em obras subterrâneas, conforme relatado por ROCHA \& CELESTINO (1992). Esses autores descrevem a situação ocorrida nas escavações efetuadas em 1981 na extensão Norte da linha NorteSul do METRO, as quais atingiram camadas aluviais recentes, muito compressíveis e pouco resistentes, ocorrendo instabilidade de frente, com recalques de grande porte.

Verificou-se nesse estudo que essa camada de argila orgânica, desenvolvida inclusive nas planícies aluviais de pequenas drenagens existentes no município, tem espessura pouco variável, predominando aquelas entre 1 e $2 \mathrm{~m}$, sendo verificadas entretanto, na Zona Oeste, próximo ao cruzamento da Av. Brasil com a Av. Rebouças (Córrego Verde), espessuras de até 4m.

As camadas arenosas e conglomeráticas quaternárias apresentam permeabilidade alta, conhecidas como camadas drenantes (COZZOLINO et al. 1994), no entanto não podem ser consideradas como bons aquiferos devido a contaminação atualmente existente nas camadas superficiais quaternárias dos grandes aglomerados urbanos.

A classificação MCT mostrou-se uma metodologia bastante adequada para classificação dos solos encontrados na área de estudos, sendo também efetuada experimentalmente em sedimentos alterados coletados a pequenas profundidades a partir de sondagens (PIQ-8.7, TR-BR 2.5, Tabela 3), e também em sedimentos aluviais quaternários (amostra H-AL-3). 
A maioria das amostras submetidas ao ensaio pelo Método Expedito foram coletadas em depósitos coluviais situados em diferentes encostas da área de estudo. Foram analisadas ainda amostras de solos saprolíticos (H-EMB), além de uma amostra coletada em solo superficial de colúvio ( $\mathrm{H}-\mathrm{SO}-4$ ).

Os resultados das amostras de colúvio mostraram que esses depósitos apresentam na grande maioria das vezes, comportamento laterítico $L G^{\prime}$ e $L A^{\prime}-L^{\prime} G^{\prime}$, indicando que esses depósitos, quando devidamente compactados, apresentam propriedades favoráveis para usos em aterros, proteção a erosão. Nas obras de pavimentação são adequados para utilização como revestimento primário, base de pavimento, reforço do sub-leito e sub-leito compactado. Devido a essas características, esses depósitos podem ser considerados como boas jazidas, passíveis de ser mais adequadamente exploradas no município, uma vez que têm ocorrência generalizada, embora apresentem pequenas espessuras. Essas propriedades foram também verificadas nos solos cenozóicos do interior de São Paulo por GIACHETI et al. (1993).

Verifica-se freqüentemente em escavações para área de empréstimo, a retirada da camada coluvial juntamente com a camada saprolítica subjacente, esta apresentando comportamento geotécnico pouco favorável, não laterítico, conforme pôde ser observado nas amostras analisadas neste trabalho (H-EMB-1, H-EMB-3, H-EMB-4, H-EMB-5, H-EMB-9, Tabela 3).

Ao analisar o comportamento in situ dos depósitos coluviais em taludes de corte, verifica-se que esses depósitos apresentam grande susceptibilidade à erosão quando saturados. No entanto, quando secos, mostram-se estáveis inclusive em taludes com alta declividade. ROCHA (1993) ao estudar os colúvios situados na Vista Chinesa, na cidade do Rio de Janeiro, verificou que esses depósitos, os quais apresentam semelhanças com os encontrados na área de estudos, permanecem estáveis, durante a estação seca, inclusive em taludes negativos.

Esse comportamento diferenciado dos depósitos coluviais pode levar a interpretações equivocadas quanto à susceptibilidade dos mesmos ao risco de escorregamento. Áreas ocupadas situadas em encostas onde verifica-se a presença de colúvios em exposição poderiam ser consideradas, a princípio, como área de risco, pois estariam sujeitas a escorregamentos em épocas de pluviosidade intensa. É necessário naturalmente, um estudo detalhado dos condicionantes naturais e antrópicos de cada área identificada, para determinação dos graus de risco ali existentes. 
A ocorrência de escorregamentos envolvendo camadas de colúvio geralmente obedece padrão translacional uma vez que esse processo estaria relacionado à superficie de contato colúvio/ camada sobrejacente, sobre a qual desenvolver-se-ía o movimento de massa.

A correta caracterização desses depósitos pode portanto, subsidiar o mapeamento de áreas de risco associadas à presença de colúvios, podendo ainda otimizar custos referentes a obras de contenção nessas áreas, pois tratam-se de depósitos pouco espessos. Em condições favoráveis, sugere-se a remoção dessa camada, que poderá ser recolocada no local de origem após correta compactação, ou mesmo ser utilizada em outra área. Menciona-se aqui a utilização de solo coluvial como selante em trincas de tração, com abertura de até $0.5 \mathrm{~m}$, ocorridas em talude constituído por solo saprolítico siltoso situado no Loteamento Chácara Santa Maria, em Campo Limpo. 


\section{CAPÍtulo 6}

\section{ASPECTOS TECTÔNICOS}

\subsection{INTRODUÇÃO}

O estudo dos movimentos tectônicos mais recentes (neotectônica) da área de estudos foi de certa forma prejudicado, devido fundamentalmente a falta de dados de campo. Verificou-se em alguns afloramentos estruturas (falhamentos normais principalmente) nos sedimentos terciários da Bacia de São Paulo, no entanto não foram verificados falhamentos afetando depósitos quaternários.

Em relação a sismicidade da área, MIOTO (1993) engloba as bacias de São Paulo, Taubaté, Resende, Volta Redonda, Guanabara e Graben de Barra de São João na denominada Zona Sismogênica de Cunha. Segundo o autor tais bacias não apresentam atividades sismicas próprias, citando recentes ocorrências de sismos na região de Monsuaba, Distrito de Angra dos Reis, em 1988-1989. São mencionados ainda ocorrências de sismos induzidos por reservatórios de barragens em Paraibuna-Paraitinga com intermitência desde 1977.

A falta de dados de campo obrigou uma reorientação nos trabalhos, optando-se peia elaboração de mapa de gradientes hidráulicos da área. Esse método foi utilizado com sucesso na análise tectônica da área da Volta Grande do Rio Xingu, em Altamira, PA (RODRIGUEZ 1993) e na região do Vale do Paraíba próximo a Soleira de Queluz (SALVADOR 1994).

A análise neotectônica apresentada é baseada essencialmente em informações indiretas, extraídas do mapa de gradientes hidráulicos efetuado a partir de 3422 dados (drenagem de $2^{\mathrm{a}}$. ordem) coletados em mapas topográficos em escala 1:25.000.

Foram elaborados mapas de gradientes hidráulicos de área envolvendo os limites do municipio de São Paulo entre as coordenadas E $310-370 \mathrm{~km}$ e N7.345 - $7.425 \mathrm{~km}$, sendo que a informação linear obtida (traçado da drenagem) foi reduzida a um dado pontual referente a distância média entre a foz e a cabeceira da drenagem (Figura 25).

O valor de gradiente hidráulico obtido em cada ponto foi multiplicado por 100 por questões operacionais, para facilitar o manuseio (digitação) e representação dos dados. Os mapas elaborados são apresentados nas figuras 26 e 27 e Anexo $C$. 


\subsection{ANÁLISE DOS MAPAS DE GRADIENTES HIDRÁULICOS}

A análise do mapa de gradientes hidráulicos pode indicar movimentações recentes uma vez que as drenagens são feições da paisagem atual que refletem ou ressaltam estruturas presentes no relevo. BJORNBERG (1992) identificou através do estudo de perfis ao longo de drenagens situadas na Zona Norte de São Paulo, a presença de quebras (kick points) que indicariam segundo o autor, a presença de movimentações no relevo local.

Entretanto as estruturas mencionadas anteriormente podem apresentar caráter passivo representado por lineamentos de falhas antigas, ou feições como xistosidade, acamamento, etc. Pode haver ainda diferenciação no padrão de drenagens quando essas percorrerem terrenos com diferentes permeabilidades, indicando essencialmente mudanças litológicas. Nesses casos as anomalias refletidas no mapa de gradientes hidráulicos não representariam, salvo evidências adicionais, atividades neotectônicas. Deve-se considerar ainda reativações mais jovens ao longo de antigas estruturas, padrão esse bastante comum na área de estudos, relacionado com a própria origem da Bacia de São Paulo, conforme descrito por diversos autores.

Observando-se os mapas apresentados nas figuras 26 e 27 e Anexo $\mathrm{C}$, nota-se à primeira vista dois padrões de espaçamento de curvas, que representam, grosso modo, a área de ocorrência de sedimentos da bacia, definida pelo padrão mais espaçado, e de rochas do embasamento, onde se verifica um padrão concentrado de curvas.

No mapa de gradientes hidráulicos apresentado no Anexo $\mathrm{C}$ foram traçados lineamentos unindo picos com altos valores de gradientes hidráulicos (lineamentos em cor laranja), além de falhamentos definidos na área por diferentes autores (representados pela cor azul), na maioria das vezes relacionadas com a tectônica sin e pós deposicional da Bacia de São Paulo. 
(UTM) $\mathrm{m}$

7420000

7400000

7370000

$N$

7360000

7350000

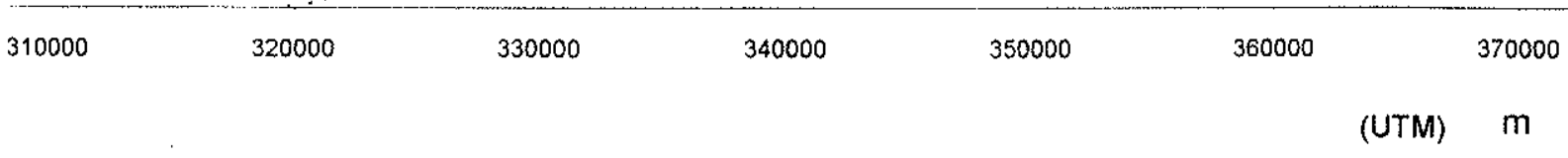

FIGURA 25 - MAPA DE LOCALIZAÇÃO DE PONTOS PARA CONFECÇÄO DE GRADIENTES HIDRÁULICOS 


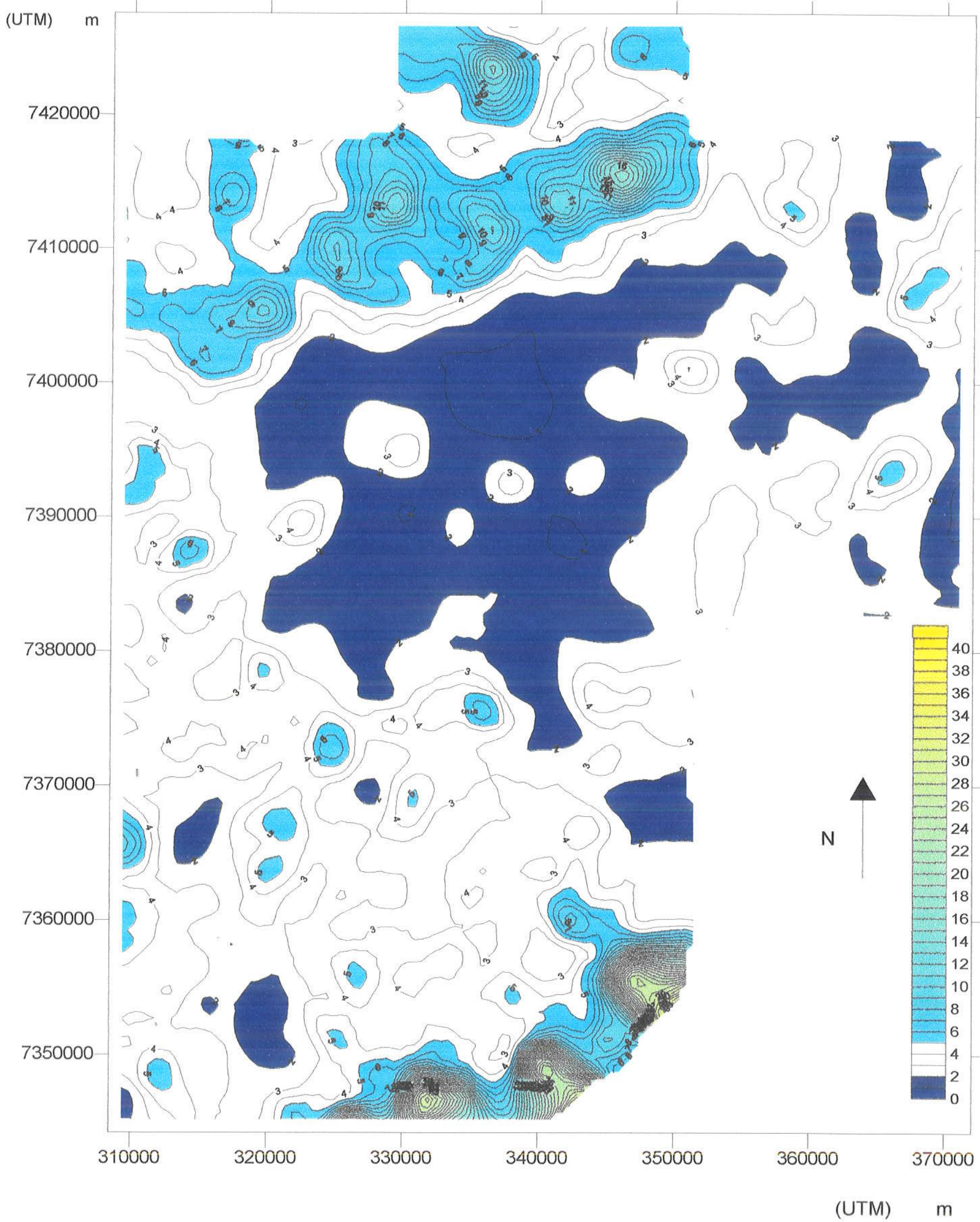

FIGURA 26 - MAPA DE ISOVALORES DE GRADIENTES HIDRÁULICOS 


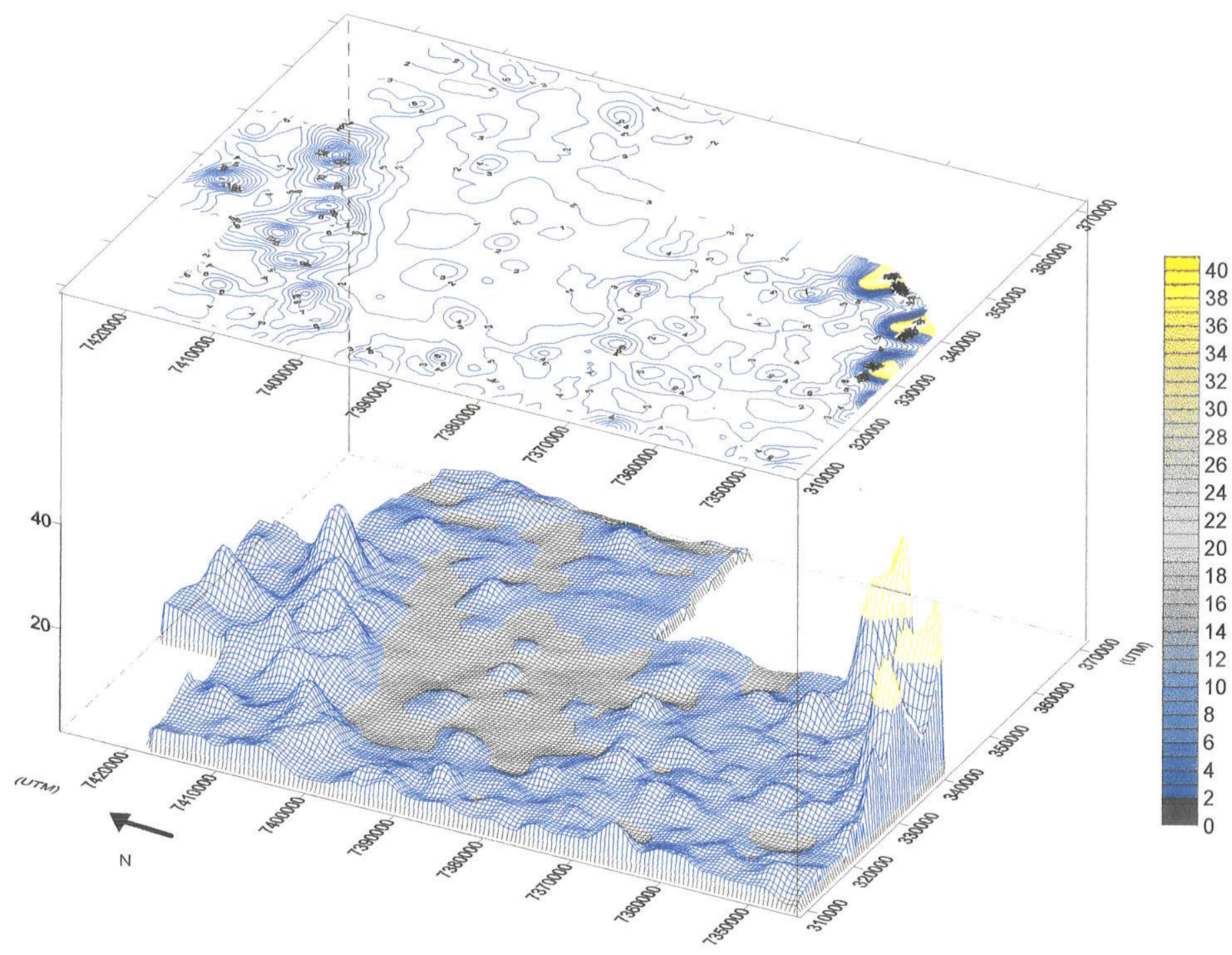

FIGURA 27 MAPA DE ISOVALORES DE GRADIENTES HIDRÁULICOS - 3D E PROJEÇÃO 
Verifica-se que o compartimento tectônico delimitado pelas falhas de Caucaia-Jaguari e Falha do Rio Pirajussara-Buquira (lineamentos maiores localizados no centro do mapa, de direção $\mathrm{NE}$ ), situada na área de ocorrência de sedimentos da bacia, apresenta uma concentração de valores maiores de gradientes hidráulicos o que sugere que nessas áreas possam ter ocorrido atividades neotectônicas, conforme já mencionado por outros autores (RICCOMINI 1989; RICCOMINI \& COIMBRA 1992).

A falha do rio Pirajussara conforme traçado proposto por TAKIYA et al. 1989 e falhamento sobre o Rio Tamanduateí (RICCOMINI \& COIMBRA 1992) apontadas no mapa (Anexo $\mathrm{C}$ ), coincidem com alinhamentos de valores anômalos. Embora não tenham sido descritas evidências diretas de atividades neotectônicas nos locais mencionados, as concentrações de valores anômalos verificados poderiam indicar reativação dessas estruturas .

São verificados três alinhamentos a $\mathrm{SW}$ da área de direção NW, aproximadamente paralelos entre si, e um quarto alinhamento, cortando os demais, de direção NE. Essas feições lineares foram consideradas com prováveis estruturas tectônicas pois representam concentrações de valores altos de gradientes hidráulicos, embora deva-se considerar que esses alinhamentos interceptam diferentes litologias do embasamento e da bacia sedimentar. No entanto, a interpretação é devida o comportamento diferenciado das drenagens em áreas próximas aos alinhamentos, com as mesmas litologias.

Já o padrão "em dominó" verificado ao norte da área, no domínio da Serra da Cantareira, seria indicativo de atividades tectônicas com componente transcorrente, podendo estar relacionada a fase tectônica com transcorrência dextral E-W com compressão NW-SE definida por RICCOMINI (1989) para a evolução do Rift Continental do Sudeste do Brasil, à qual é atribuída idade pleistocênica superior. 


\section{CAPÍtulo 7}

\section{GEOLOGIA URBANA}

\subsection{INTRODUÇÃO}

A aplicação do conhecimento geológico como subsídio ao planejamento do uso e ocupação do solo urbano, e na solução ou minimização de problemas ambientais emergentes, decorrentes do confronto ocupação/ condições naturais é aqui denominado de geologia urbana.

Cabe mencionar a criação de um Grupo Internacional de Trabalho em Geologia Urbana, em 1992 (MULDER 1993), atuando no âmbito da Comissão das Ciências Geológicas para o Planejamento Ambiental - COGEOENVIRONMENT da IUGS, da Associação Internacional de Geologia de Engenharia - IAEG, e da Associação Internacional de Hidrogeólogos - IAH. O Grupo conta com cerca de 50 membros reunindo experiências em 176 grandes cidades.

Nos últimos anos, o crescente interesse da comunidade geológica nacional por esta área da geologia aplicada pode ser constatado pelo aumento expressivo no volume de trabalhos encaminhados aos eventos realizados pela Sociedade Brasileira de Geologia (e.g. SBG-SP/RJ 1991; SBG 1992; SBG SP/RJ 1993), bem como pelo número de dissertações e teses acadêmicas. Em 1994 a SBG organizou no $38^{\circ}$ Congresso Brasileiro de Geologia um Simpósio com o título Geologia Urbana

Essa tendência é um dos muitos indicativos de que nos últimos anos tem crescido o campo de atuação do geólogo em áreas da geologia aplicada, notadamente nas áreas urbanas, campo esse não tradicional de ocupação desse profissional .

Nesse sentido justificam-se adaptações efetuadas nos curriculuns de geologia para melhor preparar o geólogo a este mercado de trabalho, merecendo citação as recentes modificações e discussões efetuadas sobre o mesmo nos cursos de geologia da Universidade de São Paulo-USP (CORDANI 1996) e da Universidade Estadual Paulista-UNESP. Ressalta-se ainda a proposta de criação de disciplina denominada "Geologia Urbana" apresentada por LANDIM \& POTTER (1995) e LANDIM \& POTTER (1996).

A realização da Conferência das Nações Unidas sobre Ambiente e Desenvolvimento (RIO 92), que reuniu o maior número de Chefes de Estado da história, e que despertou, mundialmente, a consciência para a questão ambiental, é exemplo da relevância do tema. No âmbito local, esse 
evento e sua repercussão praticamente obrigou o poder público a tomar consciência e desenvolver politicas visando resolver os graves problemas ambientais existentes especialmente nas grandes cidades.

No Município de São Paulo os problemas ambientais são ainda agravados face o elevado número e concentração de seus habitantes.

\subsection{PRINCIPAIS PROBLEMAS AMBIENTAIS DO MUNICÍPIO DE SÃO PAULO}

A elaboração das Agendas 21 locais nos grandes municípios brasileiros demonstra que a questão ambiental representa um grande desafio a ser enfrentado pelo poder público e pela própria sociedade no próximo século, constituindo-se em documento de subsídio à política e a gestão ambientais urbanas.

No Município de São Paulo a elaboração da Agenda 21 local vem sendo discutida desde 1992, com a apresentação de alguns documentos parciais. No ano de 1996 foi apresentado pela Secretaria do Verde e Meio Ambiente o texto "Agenda 21- Compromisso do Município de São Paulo" (PMSP-SVMA 1996). São relacionados a seguir, de forma concisa, alguns dos grandes problemas ambientais dessa metrópole, levantados nesse documento.

Transporte e trânsito são considerados atualmente em São Paulo sinônimos de graves problemas como congestionamento e poluição do ar e sonora. Segundo dados do Departamento de Trânsito- DETRAN, em 1994 havia uma frota de 4.400 .000 de veículos registrados, sendo 43.000 ônibus, 157.000 caminhões e 3.800.000 autos. A Companhia de Engenharia de Tráfego estima que $25 \%$ da frota nacional ( 2,7 milhões de veículos) circula diariamente na cidade (PMSP - SVMA).

Segundo dados da CETESB (CETESB 1996), a Região Metropolitana de São Paulo e o Municipio de Cubatão representam dentro do Estado de São Paulo, áreas distintas em termos de poluição do ar. As regiões mencionadas apresentam altos niveis de comprometimento de poluição do ar, relacionada principalmente a emissão de gases por veículos automotores, levando a medidas de controle, pelo poder público, como o Programa de Controle de Poluição do Ar por Veículos Automotores - PROCONVE.

$\mathrm{Na}$ Região Metropolitana de São Paulo as concentrações de monóxido de carbono excedem rotineiramente, por uma grande margem, os padrões de qualidade do ar para 8 horas ( $9 \mathrm{ppm}$ ) na 
maioria dos locais de coleta de amostras pela CETESB. O nível de atenção é freqüentemente ultrapassado chegando a concentrações de até $20 \mathrm{ppm}$. Essa mesma tendência é verificada para o dióxido de nitrogênio (CETESB 1996).

Os dados apresentados indicam a necessidade de adoção de propostas e soluções que priorizem e estimulem o transporte coletivo.

Quanto ao sistema de limpeza urbana do município, verifica-se gastos bastante elevados, consumindo do cofre público municipal pouco mais de $\mathrm{R} \$ 31.000 .000,00 /$ mês (média mensal janeiro-agosto 1996) (PMSP - LIMPURB 1996). A média diária no período de janeiro a junho de 1996 de resíduos primários recebidos nas unidades de tratamento e destino no Município foi de 18.770 t/dia. A coleta de resíduos sólidos na cidade é representada por $67 \%$ de lixo domiciliar, $27 \%$ de entulho, $5 \%$ de resíduos industriais, classes II e III, e $1 \%$ referente a serviços de saúde (PMSP - SVMA 1996).

Em relação aos resíduos domiciliares, $60 \%$ correspondem a matéria orgânica, $14 \%$ a papel/ papelão, $11.5 \%$ a plástico duro/filme, $5 \%$ a metais, $5 \%$ a vidro e $4.5 \%$ a outros materiais.

O destino de cerca de $90 \%$ dos resíduos do município são os aterros sanitários em operação (Bandeirantes e São João e Itatinga), sendo aproximadamente $8 \%$ transformados em composto orgânico nas usinas de Vila Leopoldina e São Matheus. Os incineradores Vergueiro e Ponte Pequena recebem os $2 \%$ restantes, incluído o resíduo de serviços de saúde (PMSP - SVMA 1996).

Dentre as ações propostas na Agenda 21 do Município de São Paulo quanto a gestão dos resíduos sólidos destaca-se: incentivos fiscais a indústrias que mantiverem programas de redução de residuos na fonte, adequação e reciclagem de embalagens; ampliação do sistema de coleta seletiva de materiais recicláveis com a instalação de Centros de Triagem; adoção, para residuos domiciliares, da segregação na fonte do lixo úmido e seco, a serem coletados em sacos separados, propiciando a macro reciclagem.

A ocupação das várzeas quer por moradias ou por rede viária, o assoreamento das drenagens, as canalizações sub-dimensionadas, a constante impermeabilização dos terrenos do Municipio podem ser consideradas como as principais causas das inundações existentes em São Paulo. A rede fluvial paulistana é estimada em cerca de $1500 \mathrm{~km}$, sendo que a extensão das canalizações até o ano de 1993 somava $413 \mathrm{~km}$ (PMSP - SVMA 1996). Em 1979 estavam 
cadastrados pela Secretaria de Vias Públicas do Município 125 pontos de enchentes, que em 1990 passaram a 403 pontos, perfazendo cerca de $24 \mathrm{~km}^{2}$ de área inundável.

O problema das inundações em São Paulo é tema complexo. Envolve uma situação já definida de ocupação com tendências de agravamento (ou seja, aumento da área impermeabilizada), interagindo com processos naturais de desenvolvimento fluvial, pois entende-se que esses processos atuam no âmbito de sub-bacias e bacias como um todo, e não em trechos isolados.

Em termos de ações propostas para gerenciamento das drenagens, a Agenda 21 do Município propõe a elaboração de um Plano de Gestão de Drenagem, que prevê entre outras ações, um programa de educação ambiental, diagnóstico da situação (determinação das áreas inundáveis, identificação de usos irregulares do solo), propostas de intervenções (obras estruturais e não estruturais) com estimativas de custos, além de medidas de controle como as de combate à erosão, ao assoreamento, a disposição irregular de lixo, etc.

As áreas verdes hoje existentes no Município somam $154 \mathrm{~km}^{2}$ ou seja $10,2 \%$ da área total, representadas por espaços públicos e particulares, concentrados principalmente nas regiões Sul (área de proteção aos mananciais) e Oeste. Os parques e praças públicas representam apenas 42,3 $\mathrm{km}^{2}$. As invasões de áreas verdes, principalmente por favelas, traduzem-se a cada dia na diminuição dessas áreas, consideradas como fundamentais na preservação da qualidade de vida do cidadão paulistano. Por outro lado aflora o grave problema da falta de moradia existente no municipio.

Segundo dados oficiais mais da metade da população do Munícipio (51\%) vive em condições muito precárias (Tabela 4) quer seja em favelas (1.902.000 hab), em cortiços (595.000 hab.), ou em loteamentos clandestinos (2.500.000). Esses valores surpreendentes corroboram uma constatação defendida no presente trabalho, já levantada em estudos feitos por técnicos da Secretaria Municipal do Planejamento (ROLNIK et $a l$. s/d) que consideram a questão da habitação precária como um dos mais graves problemas ambientais existentes no Município de São Paulo. Em consequência, vários são os impactos gerados, dentre eles, a ocupação de áreas frágeis, não propícias a implantação de moradias, gerando assim áreas, de risco geológico-geotécnico. 


\begin{tabular}{|c|c|c|c|c|c|}
\hline & Carência & abitaci & nal & & \\
\hline Distribuição Geral & $\mathrm{Hat}$ & ntes & Hab./Familia & & \\
\hline & (milhares) & $\%$ & Média(1) & (milhares) & $\%$ \\
\hline Favelas (1) & 1902 & 19,4 & 5,02 & 379 & 13,3 \\
\hline Cortiços (1) & 595 & 6,1 & 3,69 & 161 & 5,6 \\
\hline Lot. Irregulares (2) & 2500 & 25,5 & 4,00 & 625 & 37,5 \\
\hline Normais & 4804 & 49,0 & 3,80 & 1245 & 43,6 \\
\hline TOTAL & 9801 & 100,0 & 3,90 (média) & 2856 & 100,0 \\
\hline $\begin{array}{l}\text { Fontes: (1) PMSP. SEHAE } \\
\text { (2) PMSP. SEHAE }\end{array}$ & $\begin{array}{l}\text { E. Estudos d } \\
\text { Loteament }\end{array}$ & $\begin{array}{l}\text { avelas e Cor } \\
\text { egulares. Se }\end{array}$ & de São Paulo. & & \\
\hline
\end{tabular}

Tabela 4. Carência Habitacional no Município de São Paulo (PMSP SVMA 1996).

\subsection{ESTUDO DE CASOS EM ÁREAS DE RISCO GEOLÓGICO - GEOTÉCNICO}

\subsubsection{INTRODUÇÃO}

Os escorregamentos são ressaltados nesse trabalho por serem considerados um dos principais problemas geológico-geotécnico existentes no Municipio, uma vez que os acidentes ocorridos envolvendo movimentos de massa produzem, infelizmente a cada ano, centenas de vítimas, algumas fatais.

No periodo de setembro de 1994 a março de 1995 foram registrados pelas 26 Administrações Regionais do município 473 pontos de ocorrência de inundação, deslizamento, e inundação/deslizamento (solapamento). A Regional de Campo Limpo apresentou o maior índice de ocorrência ( $31 \%)$, sendo também a região que onde registrou-se o maior número de ocorrência de deslizamentos, 20,9\% do total verificado em São Paulo.(PMSP-SAR).

Os terrenos mais susceptiveis a erosão e escorregamentos situam-se predominantemente em área de ocorrência de embasamento pré-cambriano, o qual não foi objeto do presente estudo. 
Entretanto, como já discutido no item 5.2.2 os depósitos coluviais observados ocorrem predominantemente recobrindo essas rochas mais antigas.

A sudoeste do município, região do Campo Limpo, onde esses depósitos foram melhor caracterizados coincide com a área de ocorrência expressiva de escorregamentos. Esses acidentes estão associados quase que exclusivamente às áreas de favelas ou loteamentos clandestinos. Essas áreas representam cerca de um quarto do total de aproximadamente 1800 favelas existentes no município, bem como abriga grande número de loteamentos em desacordo com as normas técnicas e legais da Secretaria da Habitação e Desenvolvimento Urbano - SEHAB.

Em Campo Limpo, a maioria de seus aproximadamente 800.000 habitantes (IBGE 1991) vivem em condições de infra-estrutura urbana (malha viária, transporte coletivo, saneamento básico, entre outros) bastante precárias, constituindo-se em uma das regiões mais carentes do município.

No extremo sul dessa região próximo a represa do Guarapiranga em Área de Proteção aos Mananciais, ocorrem ainda pequenas áreas de sedimentos terciários, mais favoráveis a ocupação. Uma segunda ocorrência desses sedimentos, referentes a depósitos da Formação Resende encontrase mapeada próximo ao Rio Pinheiros (Anexo A), sendo essa, de maior importância devido sua maior expressão em área, e a sua localização mais central. A ocupação dessa área "privilegiada" em termos de comportamento geológico-geotécnico se dá por uma classe social igualmente privilegiada, concentrando-se moradias e edificios de elevado padrão construtivo, no chamado novo Morumbi.

Em relação áreas de risco geológico-geotécnico existentes, foram cadastradas em 1991, pelo Grupo de Trabalho em Áreas de Risco da Administração Regional de Campo Limpo, 37 áreas de alto risco a escorregamento. Devido a dinâmica da ocupação atualmente esse número chega a quase 50.

Os problemas associados a escorregamentos são verificados também em outras regiões do município, principalmente na área norte (Freguesia do Ó, Piqueri e Santana) e leste (Itaquera e São Miguel). Entretanto serão prioritariamente mencionados no próximo item, exemplos de ocorrências de escorregamentos na região de Campo Limpo, por ser a mais critica em relação a esse aspecto, e ainda, por ter sido melhor estudada no presente trabalho. 
Ressalta-se que os escorregamentos na região de Campo Limpo ocorrem também associados a aterros lançados, a solos saprolíticos, a estruturas reliquiares presentes nos maciços de solo/rocha (fraturas, xistosidade etc), entre outros.

É evidente que as ações necessárias no sentido de minimizar esses acidentes dependem de decisões políticas, e essas, infelizmente, muito pouco priorizam intervenções em áreas mais carentes, situadas na periferia do Municipio.

O trabalho do geólogo que atua em áreas de risco geológico-geotécnico reveste-se de maior complexidade pois soma-se as suas atividades tradicionais, a função social, pois esse profissional deverá considerar em seus laudos técnicos não só as condições naturais do terreno, mas também as modificações ali impressas pelo homem, e sua condição de ocupação.

As áreas de risco aqui descritas a seguir referem-se a ocorrências atendidas pelo Grupo de Trabalho em Áreas de Risco da Administração Regional de Campo Limpo no período de 1991 a 1996. A autora do presente trabalho participou desse Grupo como Co-coordenadora entre os anos 1991 e 1994.

\subsubsection{JARDIM PARANAPANEMA}

\subsubsection{CONSIDERAÇÕES GERAIS}

A área do Jardim Paranapanema situa-se na região sudoeste do Município de São Paulo, em Campo Limpo, próxima à Estrada do M Boi Mirim. Duas zonas podem ser definidas dentro da gleba; a Zona 1, constituída por encosta delimitada pelas ruas Orlando Araújo Braga, José Augusto Bartholo, Estrada de M'Boi Mirim (Figuras 28 e fotografia 49) e a Zona 2, localizada entre as ruas Vulnerária, Diamante Verde e Andrea Sansovino (Fotografia 50, 51). O relevo nessas duas zonas é acentuado, predominando encostas com declividades maiores que $40 \%$.

Nos taludes de corte verifica-se a presença de solo saprolítico proveniente de rocha gnaíssica/ migmatítica de coloração rosa a arroxeado, micáceo, com grande susceptibilidade a erosão. Sobre o solo saprolítico assenta-se camada coluvial de coloração marrom, argilo- arenoso, com presença de stone line na base da mesma. Esses depósitos coluviais apresentam em seu topo, uma linha de carvão bem definida, os quais foram datados no presente estudo e forneceram idades 
de 0 anos $\mathrm{AP}$ e $610+/ 80$ anos $\mathrm{AP}$, respectivamente para os colúvios das zonas 1 e 2 . Os ensaios para classificação MCT indicaram que esses depósitos apresentam comportamento laterítico (LG ).

Principalmente na zona 1 notou-se uma camada superficial de aterro, constituído predominantemente por solo micáceo, siltoso, mole, de coloração rosada proveniente de escavações do solo saprolítico.

\subsubsection{ANÁLISE DE RISCO}

A análise de risco aqui apresentada refere-se à situação da área em Agosto de 1993, quando elaborou-se relatório técnico pelo Grupo de Trabalho em Áreas de Risco juntamente com o Geól. Alex U. G. Peloggia, da Secretaria da Habitação e Desenvolvimento Urbano.

\section{ZONA 1}

A zona 1 é constituída por taludes de corte com alta declividade, com setores com mais de $60 \%$ (Fotografia 52), constituídos por solo saprolítico sobreposto por camada de aproximadamente $2 \mathrm{~m}$ de colúvio. Esses encontram-se capeados por aterro apresentando cerca de $1.2 \mathrm{~m}$ na porção média do talude, e $0.5 \mathrm{~m}$ na base do mesmo. Nas porções superiores do talude não se verifica a presença das camadas de aterro e colúvio. 


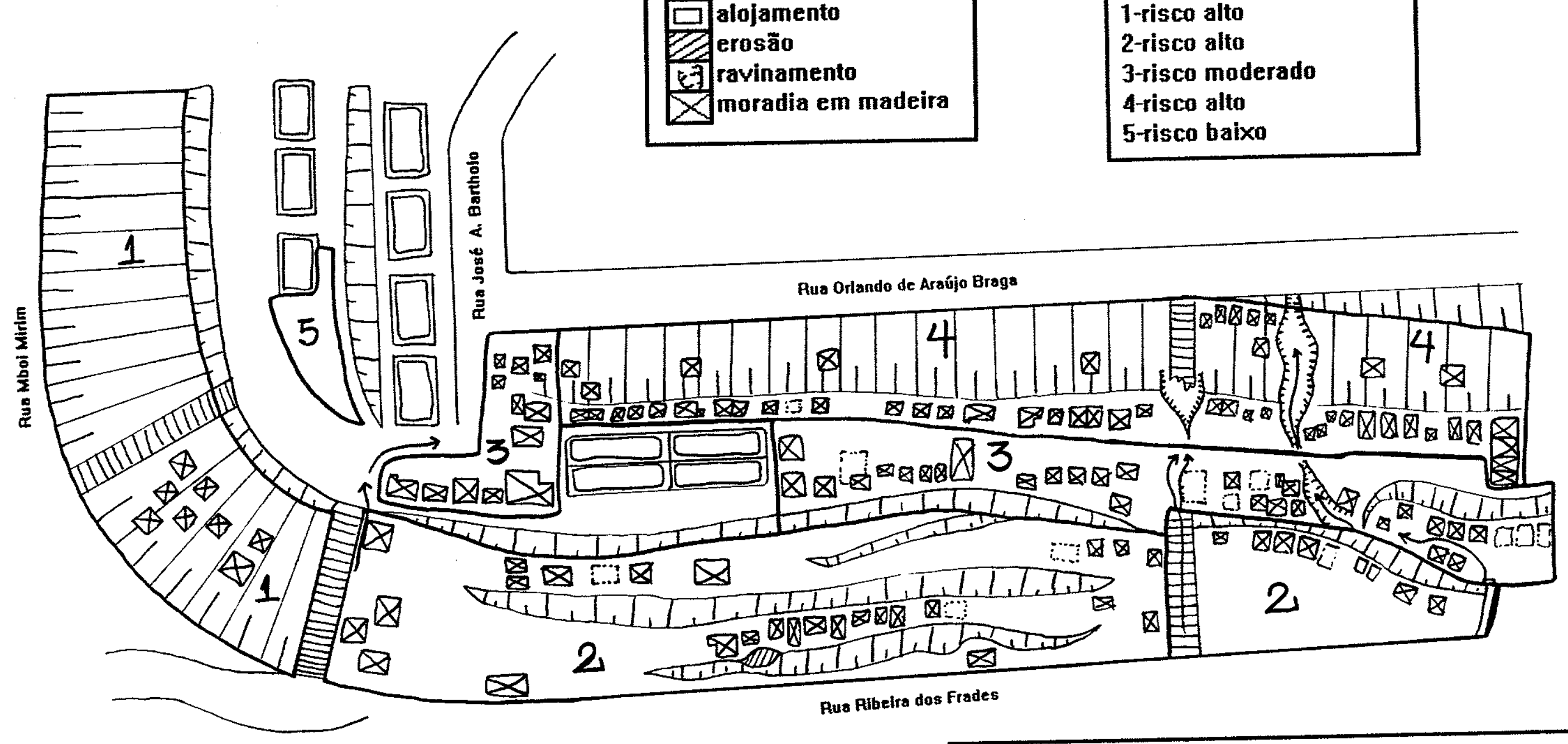




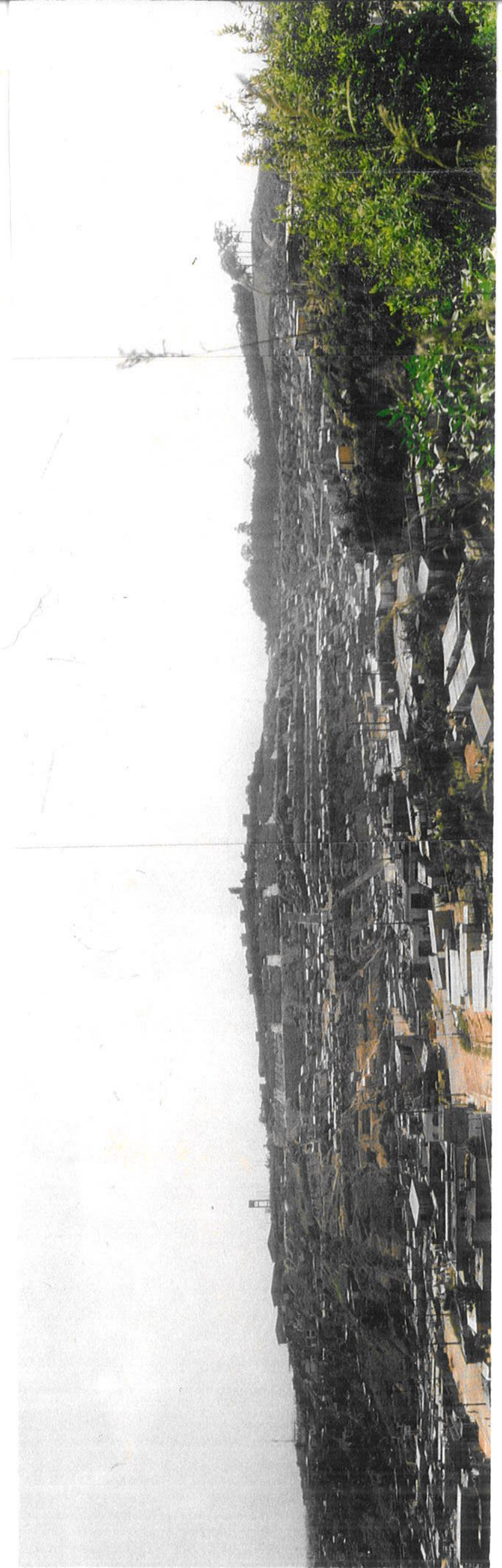

Fotografia 49. Vista panorâmica da Zona 1. Jardim Paranapanema, Campo Limpo 


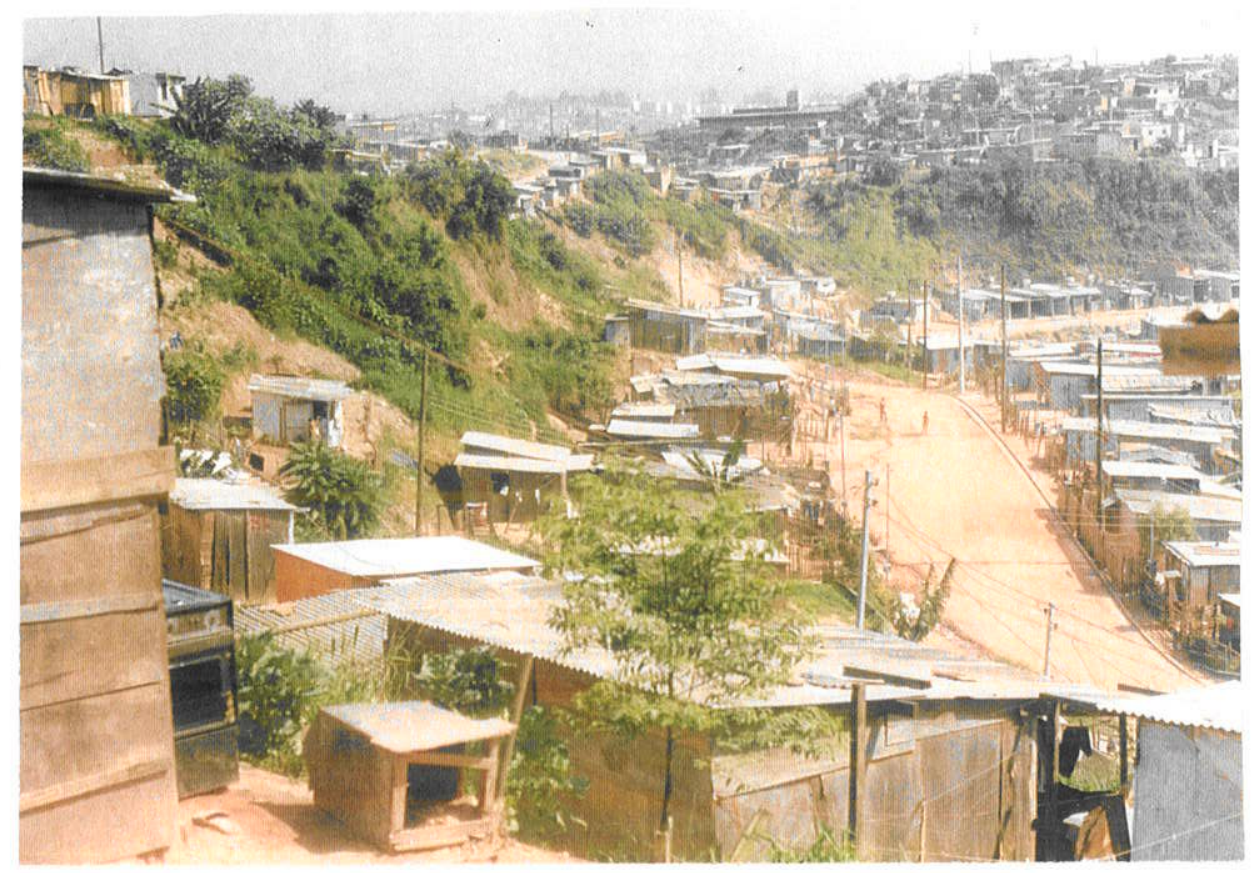

Fotografia 50. Rua Andrea Sansovino, Setor 2, Jardim Paranapanema, Campo Limpo

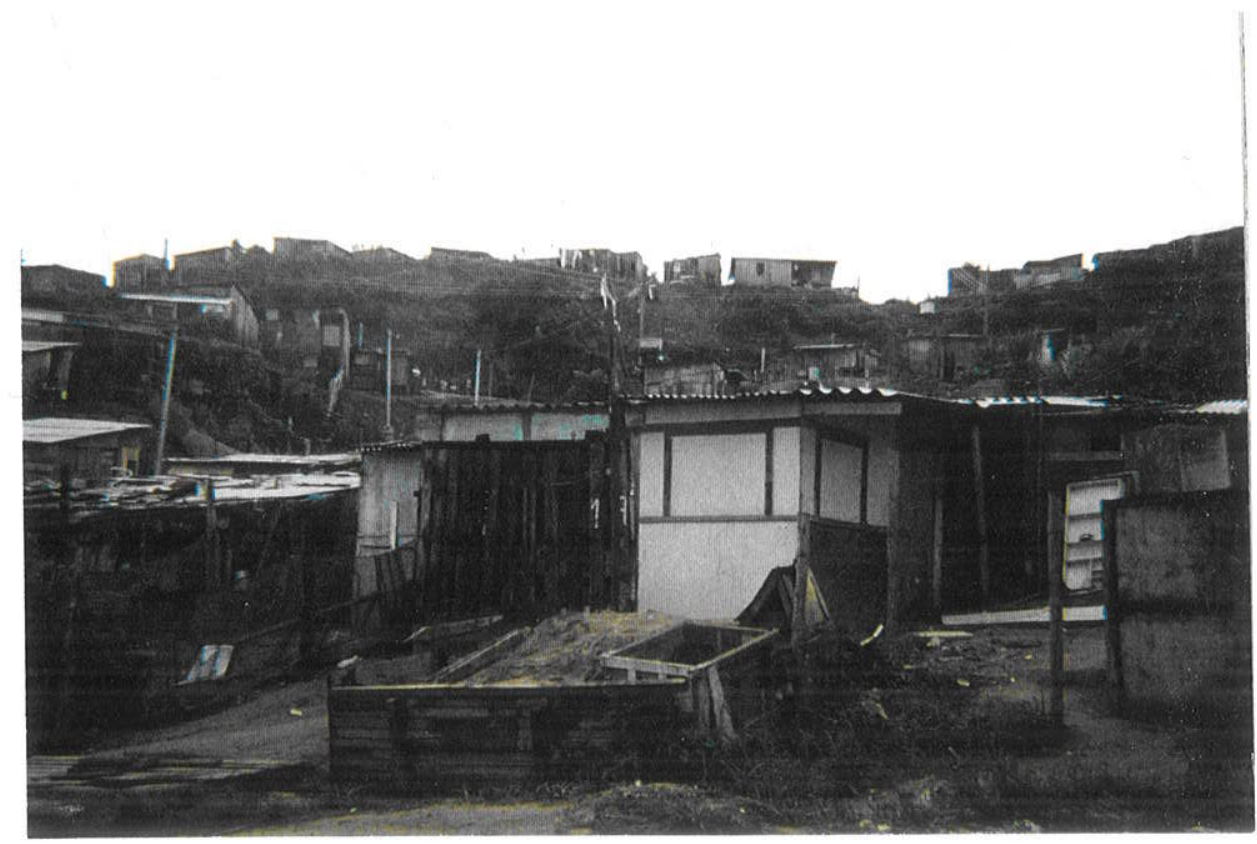

Fotografia 51. Vista de talude a partir da Rua Andrea Sansovino 


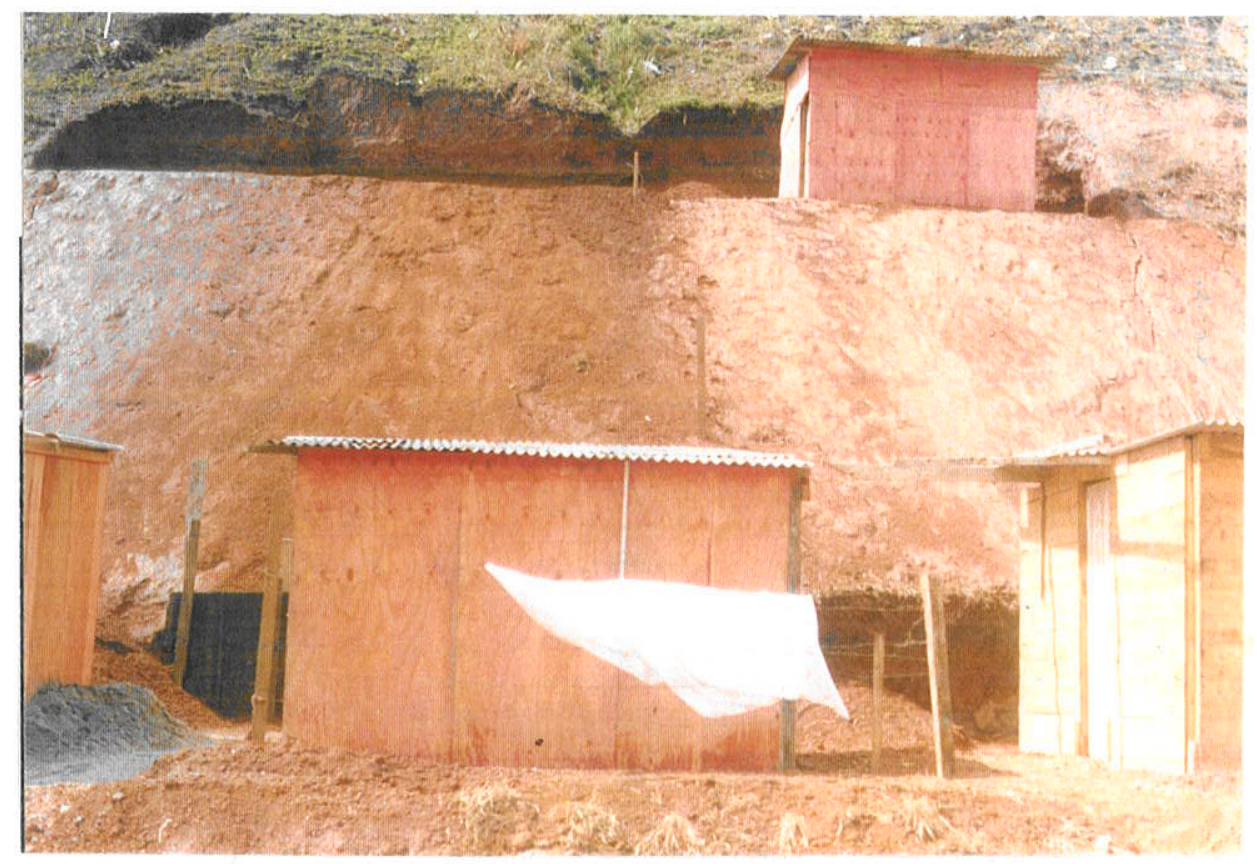

Fotografia 52. Talude de corte situado no setor 1. A camada superficial constitue-se de aterro, podendo-se notar no patamar superior, o contato com colúvio de coloração marrom.

A setorização de risco efetuada na zona 1 delimitou 5 setores de risco a escorregamento (Figura 28), com graus variando de baixo a alto risco, descritos a seguir:

- Setor 1 (37 moradias) - Alto Risco. Esse setor apresenta alto risco de queda ou atingimento de moradias por escorregamentos.

- Setor 2 (38 moradias) - Alto Risco. Setor com alto risco de queda ou atingimento de moradias por escorregamento envolvendo material de aterro e coluvial, ou por erosão dos taludes de corte.

- Setor 3 (48 moradias) - Risco Moderado. Setor com risco moderado de destruição de moradias por atingimento por escorregamentos dos taludes superiores.

- Setor 4 (73 moradias) - Alto Risco. Setor com alto risco de destruição de moradias por desabamento ou atingimento por escorregamentos induzidos da camada de aterro. Próximo ao ravinamento que atingiu a camada de solo coluvial e saprolítico existente nesse setor, verifica-se risco de solapamento das moradias situadas junto à essa feição. 
- Setor 5 ( 16 moradias) - Baixo risco. Esse setor apresenta baixo risco de destruição de moradias devido ao distanciamento dessas em relação à encosta.

\section{RECOMENDAÇÕES}

Como recomendações foi proposta para a área a desocupação dos setores de alto risco $(1,2$ e 4). Em relação ao setor 3, embora classificado como apresentando risco moderado, recomendouse também a desocupação, em função da precariedade das construções e da possibilidade de rápida ocupação da área.

As recomendações não foram atendidas pelo poder público, em tempo hábil para evitar que no verão de 1994/1995 ocorressem escorregamentos pontuais, especialmente setores 2 e 3. Felizmente não houve vítimas fatais.

\section{ZONA 2}

Os taludes existentes nessa área tem constituição semelhante a aqueles da Zona 1, devendo ser ressaltado que os planos de foliação observados no solo saprolítico geralmente apresentam atitudes favoráveis à estabilidade dos taludes.

No entanto verifica-se nessa área várias cicatrizes de escorregamentos que expõe a camada coluvial e saprolítica. A declividade dos taludes é acentuada, com setores com mais de 100\%, verificando-se ainda no local, a presença de fossas sépticas. Os fatores mencionados foram utilizados na definição de um setor de alto risco correspondente ao talude situado entre as ruas Andrea Sansovino e Diamante Verde (Fotografias 50 e 51), onde verificou-se moradias em risco de atingimento por escorregamento e desabamento.

Nessa área verificoumse duas ocorrências de escorregamento pontual, em fevereiro de 1992, que atingiram duas moradias de alvenaria situadas à Rua Andrea Sansovino, destruindo-as parcialmente, sem deixar vítimas. Esse movimento de massa atingiu a camada coluvial ali existente (com cerca de $2 \mathrm{~m}$ de espessura). A ruptura ocorreu na superfície de contato colúvio/solo saprolítico. A causa do acidente estaria relacionada a saturação da camada coluvial devido as chuvas intensas ocorridas no período. Esse acidente mostra um exemplo de escorregamento 
causado pela instabilidade da camada coluvial saturada, com ruptura planar, conforme discussão efetuada no ítem 5.2.

\subsubsection{FAVELA JARDIM CAPELINHA}

\subsubsection{CONSIDERACÕES GERAIS}

A Favela Jardim Capelinha situa-se próximo a Estrada de Itapecerica, entre as ruas Canuto Luis do Nascimento, Domenico Di Bartoli e Córrego dos Freitas. Apresenta aproximadamente $4.500 \mathrm{~m}^{2}$.

A área é constituída por um setor de encosta (Setor 1, Figura 29) constituído por solo de alteração de gnaisse, siltoso, micáceo, de coloração avermelhada, sobre o qual assenta-se colúvio argilo-arenoso de coloração marrom. Verifica-se ainda nesse Setor, um ravinamento pronunciado com acúmulo de grande quantidade de lixo doméstico.

A zona de baixada (Setor 2, Figura 29) constitue-se de material aluvial quaternário argiloarenoso. O córrego ali existente encontra-se assoreado por material sedimentar proveniente de solapamento de margens, entulho e lixo.

\subsubsection{ANÁLISE DE RISCO}

A análise de risco apresentada foi efetuada em Julho de 1991, e orientou as remoções efetuadas posteriormente na área, e consistiu na setorização de risco.

\section{SETOR 1}

O setor 1 situa-se em zona de encosta com declividade acentuada, com setores com mais de 100\% (Figura 29, Fotografia 53) apresentando ocupação desordenada de moradias, em sua maioria em alvenaria, construídas muitas vezes sobre delgada camada de aterro (menor que $1 \mathrm{~m}$ ). Foram verificados ao longo da encosta cicatrizes de escorregamentos antigos ocorridos na área. A moradia de $n .87$ foi considerada de risco iminente pois apresentou descalçamento de suas fundações. Já as moradias situadas ao pé da feição de ravinamento foram consideradas como apresentando alto risco. 


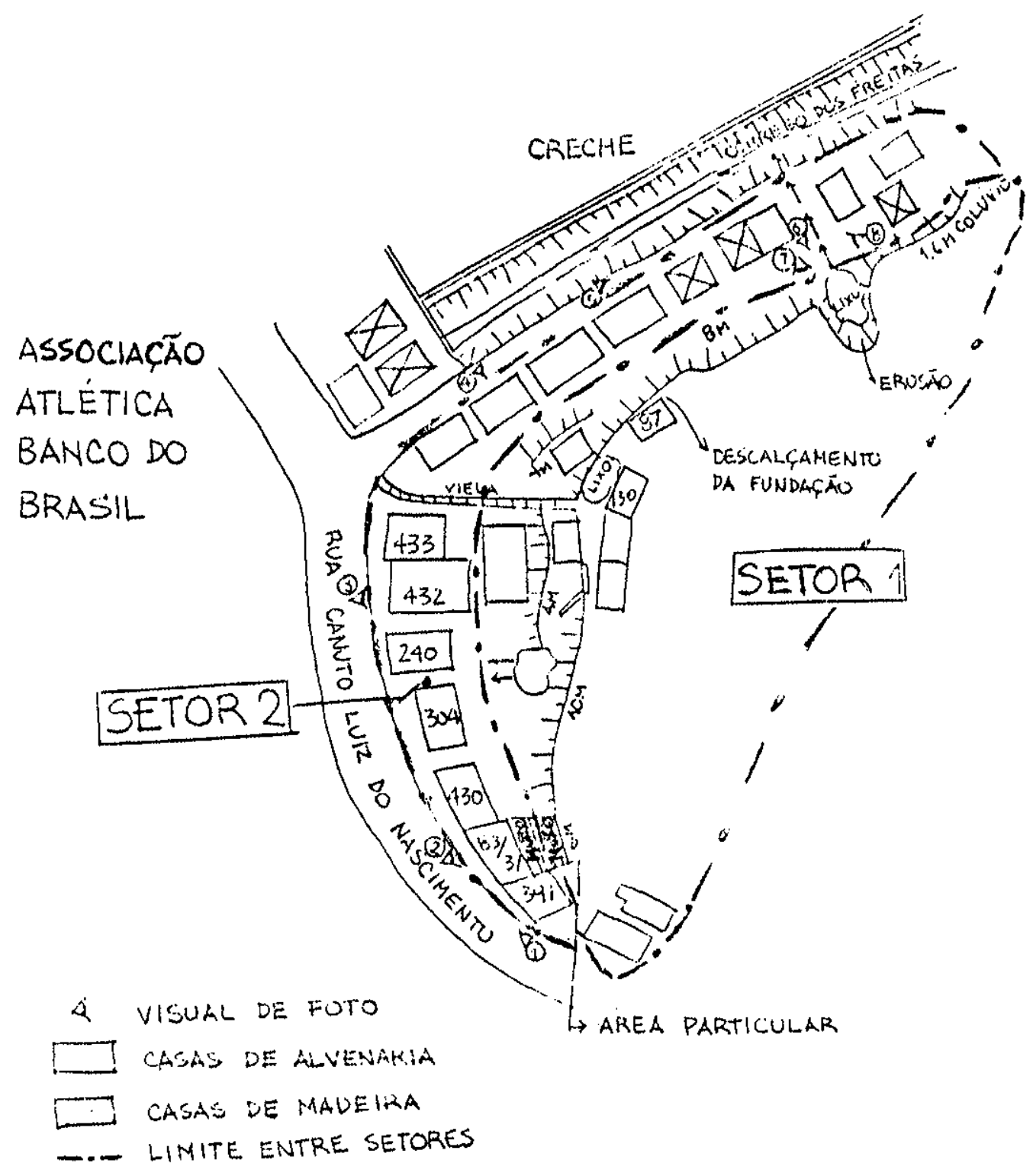

JARDIM CAPELINHA (CROQUI)

Figura 29 Setorização de risco, Jardim Capelinha, Campo Limpo. 


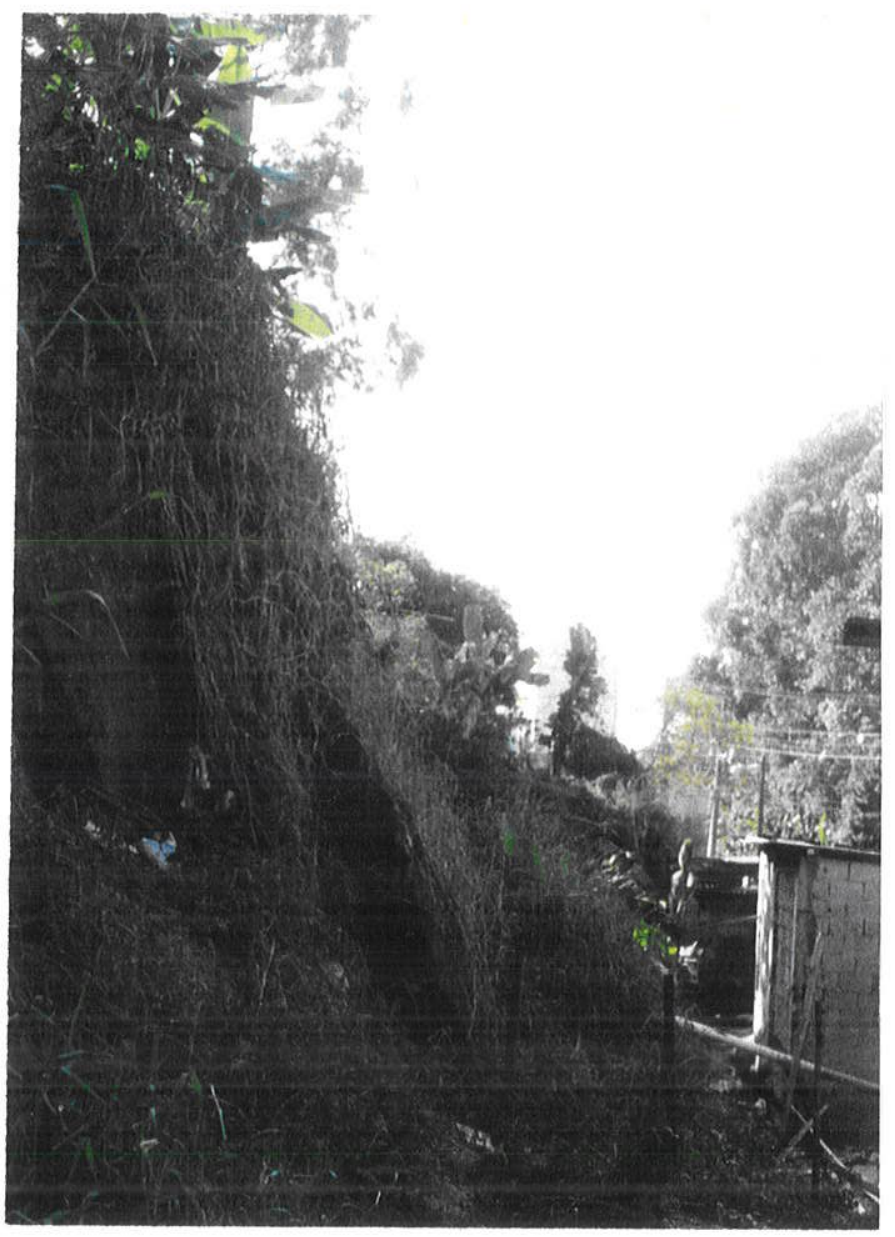

Fotografia 53. Talude de alta declividade situado no setor 1, próximo à feição de ravinamento apresentada na figura anterior. Jardim Capelinha, Campo Limpo.

\section{SETOR 2}

O setor 2 está situado em área de planície aluvial do Córrego dos Freitas. As moradias ali construídas estão sujeitas a enchentes pois encontram-se a poucos metros do leito do córrego.

As moradias assentadas ao pé do talude nesse setor, próximas a R. Canuto Luis do Nascimento, estão sujeitas a atingimento por escorregamento ou desabamento na porção superior do mesmo.

\section{RECOMENDACÕES}

Após a elaboração do laudo de risco, as seguintes recomendações foram sugeridas à Administração Regional de Campo Limpo: 
a. Limpeza e desassoreamento do Córrego do Freitas numa extensão aproximada de $200 \mathrm{~m}$;

b. Execução de obras de proteção junto as margens do córrego, para contenção do avanço do processo erosivo que ameaça a estabilidade das moradias;

c. Execução de escada hidráulica entre a Rua Domenico de Bartoli e o Córrego dos Freitas visando eliminar o ravinamento provocado por processos erosivos originados pelo fluxo concentrado de águas pluviais provenientes da Rua Chucri Lotaif (topo do talude);

d. Eliminação do lixo acumulado nos dois setores da encosta;

e. Execução de obras de canalização de águas servidas e esgotos;

f. Execução de obras de proteção do talude;

g. Remoção das moradias em alto risco.

Verificou-se o atendimento dos itens a, d e parte do g, com a ressalva de que alguns moradores removidos retornaram ao local. O item $c$ (execução de escada hidráulica) não foi executado devido a não aceitação da obra por parte dos moradores da favela. Eles alegaram receio quanto a possibilidade do local tornar-se ponto de concentração de marginais. Os itens restantes não foram executados.

Ressalta-se que esta favela é considerada uma das mais críticas em termos de ocorrência de escorregamento e enchente, pelo menos desde 1991, quando iniciou-se um trabalho sistemático de atendimento a essas áreas através da criação do Grupo de Trabalho em áreas de Risco em Campo Limpo Há vários registros de acidentes nessa favela, principalmente nas épocas de chuvas intensas.

A setorização de risco efetuada em 1991 orientou os trabalhos de remoção à época e serviu como base de ação nos anos posteriores. No ano de 1992 verificou-se novas invasões na área, principalmente no Setor 1 , junto à encosta. Vale mencionar que devido a um trabalho intenso de conscientização dos moradores nessa área foi possivel convencer um senhor idoso a deixar a sua moradia um dia antes da mesma ser totalmente atingida por escorregamento envolvendo solo saprolítico e camada coluvial ali existente. O escorregamento apresentou caráter pontual envolvendo poucos $\mathrm{m} 3$ de solo, mas suficiente para destruir por completo a moradia de 1 cômodo situada próximo à voçoroca assinalada na Figura 29. O fluxo concentrado de águas pluviais nessa área propiciou a saturação diferenciada (mais rápida) nesse setor do talude, provocando sua instabilização e conseqüente ruptura. 


\subsubsection{JARDIM COPACABANA}

A favela do Jardim Copacabana situa-se no bairro homônimo, em região de meia encosta, compreendida entre as ruas Santo Rodrigues e Santa Rita, constituída por solo saprolítico avermelhado, de alteração de gnaisse, micáceo, siltoso, sobre o qual ocorre camada coluvial argiloarenosa, porosa, de coloração avermelhada e consistência mole a média. É comum a presença de aterro lançado, composto predominantemente por material de escavação da própria camada coluvial (Fotografia 54).

A encosta foi considerada como apresentando médio risco a escorregamento, sendo individualizadas moradias com alto grau de risco ( Fotografia 54).

Foi verificado nessa área, em fevereiro de 1991, ocorrência de escorregamento envolvendo grande volume de solo coluvial e material de aterro. Como causa do acidente aponta-se o saturamento das camadas envolvidas em razão das chuvas intensas, comuns em épocas de verão, além de lançamento desordenado de águas superficiais na encosta.

O conhecimento geotécnico poderia ser utilizado nessa área no sentido de diminuir o grau de risco de escorregamento. Os aterros lançados, constituídos por solo coluvial, poderiam ser compactados em locais onde houvesse possibilidade operacional, o que contribuiria, juntamente com outras medidas, para uma maior impermeabilização do terreno, uma vez que esses depósitos apresentam comportamento laterítico quando compactados, conforme verificado no presente estudo. 


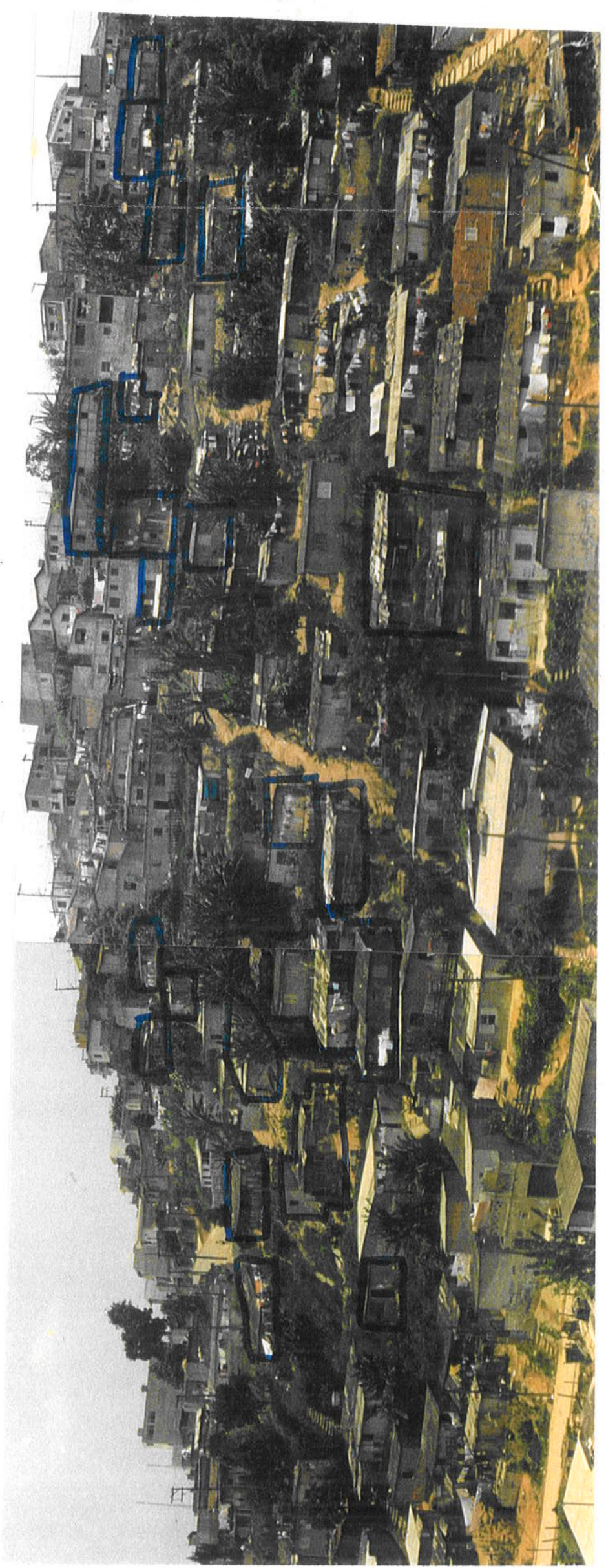

Fotografia 54. Visão panoramica da Favela Copacabana onde são destacadas (em azul) as moradias em alto risco. 


\subsubsection{SÍNTESE}

As ocorrências mencionadas anteriormente constituem-se em exemplos bastante comuns verificados não só na região de Campo Limpo como no restante do município. Mostram ainda a forma de atuação dos técnicos dessas áreas, que necessitam considerar em seus laudos e projetos de obra a expressão e vontade da população moradora da área. Entretanto, em casos de risco iminente deve prevalecer a avaliação técnica, devendo-se proceder, quando inexiste outra alternativa, a remoção imediata dos moradores e adequada acomodação dos mesmos em área segura, pois o poder público é responsável pelas áreas públicas ocupadas pelas favelas. Em caso de ocorrência de áreas de risco em propriedades particulares, igualmente a prefeitura poderá interditar o local e solicitar remoção dos moradores em risco.

São ainda listados na Tabela 5 outros exemplos de ocorrência de escorregamentos associados a camada coluvial na região de Campo Limpo.

Uma característica importante dos colúvios a ser lembrada refere-se ao seu comportamento diferenciado quando compactado, seco e saturado, conforme discussão efetuada no item 5.2. Os exemplos apresentados mostram que a presença desses depósitos em encostas desordenadamente ocupadas (com remoção da cobertura vegetal, cortes com alto ângulo, execução de aterros lançados, etc.) estão geralmente vinculados à ocorrência de escorregamentos de portes diferenciados, embora deva-se reconhecer que esse processo de movimentos de massa é muitas vezes complexo, podendo estar associado a outros fatores. De qualquer forma, essa relação foi verificada e deve ser meihor considerada pelos técnicos que atuam em áreas de risco, pois conforme observado nesse estudo, os depósitos coluviais têm ocorrência generalizada em todo munícipio, notadamente nas zonas sul e leste, onde concentram-se o maior número de favelas do município. 


\begin{tabular}{|c|c|c|}
\hline ÁREA & LOCALIZAÇÃO & TIPO DE ESCORREGAMENTO/OBSERVAÇÕES \\
\hline Jd. Nakamura & $\begin{array}{l}\text { R.Agamenon } \\
\text { Pereira da Silva }\end{array}$ & $\begin{array}{l}\text { Escorregamentos pontuais envolvendo a camada coluvial e saprolítica. } \\
\text { Foi efetuada obra de retaludamento e reurbanização na área em } 1991 .\end{array}$ \\
\hline Parque Japão & R. Huelva e Pilbarra & $\begin{array}{l}\text { Área de baixada onde ocorreram escorregamentos de pequeno porte } \\
\text { junto a r. Pilbarra, com queda de muro. Os taludes são constituidos por } \\
\text { solo coluvial e saprolítico. }\end{array}$ \\
\hline Jd. Brasul & $\begin{array}{lll}\text { R. Camasati } & \text { e } \\
\text { Manoel } & \text { Moreira de } \\
\text { Sá } & \end{array}$ & $\begin{array}{l}\text { Favela situada em meia encosta onde verifica-se presença de aterro } \\
\text { sobreposto a colúvio. Os escorregamentos pontuais ali ocorridos } \\
\text { atingiram as duas camadas. }\end{array}$ \\
\hline Jd. Rosana & $\begin{array}{l}\text { R. Frederico de } \\
\text { Azevedo Antunes }\end{array}$ & Escorregamentos pontuais envolvendo a camada de colúvio \\
\hline $\begin{array}{l}\text { Loteamento } \\
\text { Chácara Santa } \\
\text { Maria }\end{array}$ & $\begin{array}{l}\text { R. Achaira e Chaira } \\
\text { Zingerevitz }\end{array}$ & $\begin{array}{l}\text { Trincas de tração e de abatimento de grande porte (30m com aberturas } \\
\text { de } 40 \mathrm{~cm}) \text {, semicirculares observadas no topo da encosta. O maciço é } \\
\text { constituído por solo saprolítico de gnaisse, colúvio e aterro. As trincas } \\
\text { atingiram as trés camadas. Foi utilizado solo compactado de colúvio } \\
\text { como material selante nas trincas. }\end{array}$ \\
\hline Jd. Solange & \begin{tabular}{|l|} 
R. Afeganistäo e \\
Taquarembó
\end{tabular} & $\begin{array}{l}\text { Escorregamentos de pequeno porte envolvendo camadas superficiais de } \\
\text { colúvio e depósito de lixo. }\end{array}$ \\
\hline $\begin{array}{l}\text { R. Durval de } \\
\text { Almeida Santana }\end{array}$ & $\begin{array}{l}\text { R. Durval de } \\
\text { Almeida Santana }\end{array}$ & $\begin{array}{l}\text { Escorregamento pontual envolvendo camada de aterro e colúvio. foi } \\
\text { efetuada obra de contenção no local (muro de arrimo). }\end{array}$ \\
\hline
\end{tabular}

Tabela 5. Locais de ocorrência de escorregamentos associados a colúvio em Campo Limpo. 


\section{CAPÍtulo 8}

\section{CONSIDERAÇÕES FINAIS}

São Paulo, uma das maiores cidades do planeta, é considerada um exemplo típico de cidade de planalto, tendo sido desenvolvida no denominado Planalto Paulistano (ALMEIDA 1958) cujas altitudes variam entre 715 e 900 metros.

A metrópole paulistana assenta-se sobre terrenos colinosos da Bacia Sedimentar de São Paulo, adentrando a Norte e a Sul, principalmente, os morros e morrotes constituídos por rochas do embasamento pré cambriano.

As coberturas quaternárias têm ocorrência significativa na área de estudo, onde se destacam os depósitos aluviais no domínio das planícies, e os depósitos coluviais com desenvolvimento nas encostas.

Em relação aos sedimentos terciários da Bacia de São Paulo verifica-se que os mesmos encontram-se em um estágio de conhecimento avançado, inclusive do ponto de vista geotécnico, devido a intensificação de trabalhos, principalmente na última década, abordando esse tema. A contribuição do presente estudo refere-se aos estudos efetuados na Formação Resende através de sondagens com coleta de testemunhos contínuos que permitiram a descrição minuciosa desses sedimentos, sendo identificada uma camada mais endurecida na sondagem executada no Parque Piqueri, que poderia representar evidências de hidrotermalismo na região.

A ocorrência restrita dos sedimentos da Formação Itaquaquecetuba em cotas abaixo de 710 metros, em forma de pequenas bacias do tipo pull-apart (RICCOMINI 1989) dificultam a elaboração de hipóteses mais definitivas acerca de sua posição estratigráfica.

As análises palinológicas efetuadas em sedimentos da Formação Itaquaquecetuba indicaram idade eomiocênica para esses depósitos reforçando a hipótese que considera a unidade mais jovem que a Formação São Paulo.

Quanto ao comportamento geotécnico dos sedimentos da bacia, destaca-se que a classificação MCT apresentou comportamento laterítico ( $L G^{\prime}$ ) para os sedimentos argilosos da Formação Resende; entretanto os sedimentos da Formação São Paulo analisados apresentaram comportamento não laterítico. Notou-se neste trabalho uma correlação entre o aspecto " baixa susceptibilidade à erosão" dos sedimentos argilosos intemperizados da Formação Resende em taludes de corte, e a classificação LG'-comportamento laterítico. 
O estudo das coberturas quatemárias referiu-se principalmente à análise dos depósitos coluviais e aluviais presentes na área.

Embora pouco descritos na literatura, os colúvios têm ocorrência generalizada na área, sendo melhor observados na Zona Sul do município.

Os colúvios foram caracterizados nesse estudo através de observações de campo, análises petrográficas, de difratogramas de Raios X e de Microscopia Eletrônica de Varredura. Na área de estudo apresentam pequena espessura (predominantemente até $2 \mathrm{~m}$ ) e situam-se ao longo de encostas. São depósitos argilosos a areno-argilosos, porosos, mal selecionados, apresentando tons amarelados a amarronzados, em sua maioria.

Os colúvios presentes na área de estudo assentam-se predominantemente sobre rochas do embasamento, em relevo mais acidentado, sendo notados ainda sobre sedimentos terciários da bacia. Nota-se entretanto semelhanças entre esses depósitos quanto aos aspectos a textura, coloração, espessura e características geotécnicas.

Considera-se que a maioria dos depósitos coluviais observados tenha origem relacionada a movimentos lentos de massa ao longo de encostas, envolvendo material submetido a diferentes graus de intemperismo.

Freqüentemente observa-se a presença de stone line de composição variada, com ocorrência de fragmentos laterizados que poderiam representar condições climáticas mais secas associadas a sua origem. Localmente foram observadas três fases de coluvionamento representadas pela superposição desses depósitos.

As idades obtidas em datações radiocarbono indicaram duas fases de coluvionamento, há 610 +/- 80 anos AP e há 3000 +/- 140 anos AP. Não descarta-se a possibilidade de ocorrência de uma fase mais antiga, pleistocênica com idade entre 32.000 anos AP e 19.000 anos AP, identificada por diferentes autores, próximo a área de estudo.

Os depósitos aluviais quaternários têm significativa ocorrência em área, entretanto apresentam-se na maioria das vezes, cobertos por camada de aterro.

A partir dos dados obtidos (análises de campo, palinológicas e datações radiocarbono) sugere-se duas fases principais de desenvolvimento de rios meandrantes na área de estudos. A primeira situada no intervalo $32.480+/-330$ anos AP - 18.940+/- 110 anos AP relacionada, pelo menos em seu início, a condições climáticas úmidas e frias com presença de florestas de altitude exibindo elementos arbóreos como Araucaria, Podocarpus, Ilex, Myrtaceae, entre outros. Subordinadamente ocorreriam na época, campos com predomínio de Gramineae, Compositeae e 
Cyperaceae. Não descarta-se a possibilidade da presença de uma fase mais antiga de coluvionamento nesse período.

A segunda fase de desenvolvimento de rios meandrantes na área tem inicio bem marcado na passagem Holoceno-Pleistoceno, em condições climáticas úmidas com presença de florestas. Há 8000 anos AP registrou-se um período mais seco com floresta restrita; a partir de 6000 AP havia franco desenvolvimento de planícies aluviais, com sedimentação de espessos pacotes de argilas orgânicas, verificando-se há cerca de 4000 anos AP a ocorrência de clima mais úmido, próximo do atual em ambiente onde coexistiam florestas bem desenvolvidas e campos. Há cerca de 3000 anos AP constatou-se a deposição de uma fase importante de colúvios no domínio das encostas, sucedida por uma fase mais jovem, com aproximadamente 610 anos AP.

Quanto a variações climáticas ocorridas no Holoceno, a análise palinológica indicou a presença de um período mais seco há cerca de 8.000 anos AP. Embora alguns autores identifiquem a nível regional, outras fases secas no Holoceno, considera-se prematura a correlação entre os diversos dados existentes, pois a quantidade de informações é ainda insuficiente para distinção entre fases de expressão regional daquelas de ocorrência mais localizada.

Em relação ao comportamento geotécnico dos sedimentos quaternários, verifica-se que o maior problema associado aos depósitos aluviais é o recalque causado em fundações e aterros. Quanto aos colúvios, deve-se mencionar que a classificação MCT mostrou-se adequada para caracterização desses depósitos, que apresentam em sua maioria, comportamento laterítico. $\mathrm{O}$ resultado indica que esses depósitos podem ser utilizados, quando compactados, em obras de pavimentação, como camada protetora contra a erosão, e aterro.

Entretanto os depósitos coluviais in situ apresentam grande susceptibilidade a escorregamento, quando saturados. O movimento de massa é desenvolvido geralmente na superfície de contato colúvio/camada sobrejacente. A análise de seções delgadas revelou que os colúvios apresentam porosidade considerável (10\% a $25 \%$ ). Os poros observados têm formas variadas e encontram-se interligados, propiciando o avanço rápido de "frentes de saturação" e provocando a diminuição da resistência desses depósitos.

A análise tectônica da área foi efetuada através da interpretação dos mapas de isogradientes hidráulicos que indicaram reativações de estruturas já definidas por diferentes autores associadas à sedimentação da bacia. A análise dos mapas sugeriu ainda a presença de prováveis estruturas neotectônicas com direção NE-SW e NW-SE a sudoeste da área, além de feições "em dominó", a 
norte da área que poderiam apontar a presença de tectônica transcorrente dextral recente, conforme já mencionado por RICCOMINI (1989).

Em relação aos aspectos da Geologia Urbana enfatizou-se problemas ambientais relacionados a ocupação desordenada, principalmente quanto à geração de áreas de risco sujeitas a escorregamentos. Foram apresentados exemplos, de ocorrência de escorregamentos associados à presença de colúvio na região de Campo Limpo, uma vez que esses depósitos apresentam-se geralmente assentados sobre rochas do embasamento, terrenos esses, já considerados como mais frágeis à ocupação.

Optou-se pela região de Campo Limpo pois os depósitos coluviais foram melhor caracterizados na Zona Sul, além desta ser considerada a área de maior ocorrência de favelas do município. Os exemplos apresentados mostram diversos casos de escorregamentos associados à camada coluvial, tornando-se evidente a relação presença de colúvios/ ocorrência de escorregamentos, apontando-se assim, uma das aplicações do presente estudo. 


\section{REFERÊNCIAS BIBLIOGRÁFICAS}

AB'SABER, A.N. 1957. A Geomorfologia do Sítio Urbano de São Paulo. Boletim da Faculdade de Filosofia, Ciências e Letras, (Geografia 12). 219:319.

AB'SABER, A.N. 1969a. Ocorrência de Linhas de Pedras na Região de São Paulo. Ceomorfologia 10. p.910.

AB'SABER, A.N. 1969b. Contribuição ao Estudo das 'Stones lines' do Sul do Brasil. Geomorfologia 10. p.11-12.

AB'SABER, A.N. 1980. Súmula Geomorfológica do Planalto Paulistano. In: Mesa Redonda: Aspectos Geológicos e Geotécnicos da Bacia Sedimentar de São Paulo. São Paulo, 1980. Publicação Especial. São Paulo, ABGE/SBG-SP. p.33-36.

ABREU, A.A. 1992. Do Pátio do Colégio ao Planalto Paulistano: Problemas Geomorfológicos Emergentes do Sítio Metropolitano. In: PROBLEMAS GEOLÓGICOS E GEOTÉCNICOS NA REGIÃO METROPOLITANA DE SÃo PAULO. São Paulo, 1992. Publicação Especial... São Paulo, ABGE/ABAS/SBG. p.47-54.

ALMEIDA, F.F.M. 1955. As Camadas de São Paulo e a Tectônica da Serra da Cantareira. Boletim da Sociedade Brasileira de Geologia, (4):23-40.

AlMEIDA, F.F.M. 1958. O Planalto Paulistano. In: AZEVEDO, A .(ed.). A Cidade de Sáo Paulo, AGB. São Paulo, Companhia Editora Nacional. p.113-167.

ALMEIDA, F.F.M. 1964. Os Fundamentos Geológicos do Relevo Paulista. Boletim do Instituto de Geografia e Geologia, (41):169-263.

ALMEIDA, F.F.M. 1976. The System of Continental Rifts Bordering the Santos Basin, Brazil. Anais da Academia Brasileira de Ciências (suplemento). 48:15-26.

ALMEIDA, F.F.M.; RICCOMINI, C.; DEHIRA, L.K.; CAMPANHA, G.A.C. 1984. Tectônica da Formação Itaquaquecetuba na Grande São Paulo. In: CONGRESSO BRASILEIRO DE GEOLOGIA, 33. Rio de Janeiro, 1984. Anais... Rio de Janeiro, SBG. v.4, p.1794-1808.

ARAI, M. 1986. Estudo Petrográfico Preliminar dos Troncos Carbonificados da Formação Itaquaquecetuba, São Paulo, SP. Boletim do Instituto de Geociências da Universidade de São Paulo. 17:99-107.

ARAI, M. \& YAMAMOTO I. T. 1995, Novos Dados sobre a Idade da Formaçăo Itaquaquecetuba: uma Contribuição Palinológica. In: SIMPÓSIO DE GEOLOGIA DO SUDESTE, 4. Águas de São Pedro, 1995. Boletim de Resumos... Águas de São Pedro, UNESP. p.22.

ASMUS, H.E. \& FERRARI, A.L. 1978. Hipótese sobre a Causa do Tectonismo Cenozóico na Região Sudeste do Brasil. Projeto REMAC., 4:75-78.

ATENCIO, D. 1986. Sulfatos Secundários Relação com Rochas Preexistentes e Síntese. Dissertação de Mestrado apresentada ao Instituto de Geociências da Universidade de São Paulo. São Paulo. 210p.

AZEVEDO, A. 1949. O Planalto Brasileiro e o Problema da Classificação de suas Formas de Relevo. Boletim Paulista de Geografia., (2):43-53. 
AZEvedo, A. 1958. São Paulo Cidade Trimilionária. In: AZEVEDO, A .(ed.). A Cidade de São Paulo, AGB. São Paulo, Companhia Editora Nacional. p.5-40.

BIGARELLA, J.J. 1971. Variações Climáticas no Quaternário Superior e sua Datação Radiométrica pelo Método do Carbono 14. Paleoclimas, 1: 22p.

BIGARELLA, J.J. \& MOUSINHO, M.R. 1965. Considerações a Respeito dos Terraços Fluviais, Rampas de Colúvio e Várzeas. Boletim Paranaense de Geografia. 16/17:165-197.

BIGARELLA, J.J \& BECKER, R.D. -eds- 1975. International Symposium on the Quaternary. Boletim Paranaense de Geociencias, 33:370p.

BJORNBERG, A.J.S. 1992. Microestrutura em Solos. In: NEGRO Jr, A.; FERREIRA, A.A.; AlONSO, U.R.; LUZ, P.A. (eds.). Solos da Cidade de São Paulo. São Paulo, ABMS/ABEF. p.95109.

COMPANHIA DE TECNOLOGIA DE SANEAMENTO AMBIENTAL - CETESB 1996. Relatório de Qualidade do Ar no Estado de São Paulo, 1995. Série Relatórios, 78p.

CHEMEKOV, Y.F. 1982. Technogenic Deposits. In: INQUA CONGRESS, 15. Moscou, 1982. Abstracs. Moscou, INQUA. v.3, p.62.

COIMBRA, A.M.; ATENCIO, D.; BRANT NETO, M. 1980. Sulfatos Secundários associados ás aluviões antigas do Rio Tietê, (Itaquaquecetuba - S.P.). In: CONGRESSO BRASILEIRO DE GEOLOGIA, 4. Balneário de Camboriú, 1980. Anais... Balneário de Camboriú, SBG. v.4, p. 1970-1981.

COIMBRA, A.M.; RICCOMINI, C.; MELO, M.S. 1983. A Formação Itaquaquecetuba: evidências de tectonismo no quaternário paulista. In: SIMPÓSIO REGIONAL DE GEOLOGIA, 4. São Paulo, 1983. Atas... São Paulo, SBG/NSP. p.253-266.

CORDANI, U.G. 1996. A Formação do Geólogo Brasileiro para uma Sociedade em Transformação. A proposta da Universidade de São Paulo. In: CONGRESSO BRASILEIRO DE GEOLOGIA, 39. Sergipe, 1996. Anais... Sergipe, SBG. v.5, p. 70-72.

COUTINHO, J.M.V. 1980. Carta Geológica da Região Metropolitana da Cirande São Paulo, 1:100.000. EMPLASA, 2 folhas. São Paulo.

CozzollNo, V.M. 1972. Tipos de Sedimentos que Constituem a Bacia de São Paulo. Tese de doutoramento. Escola Politécnica - Universidade de São Paulo. São Paulo. 116p.

Cozzolino, V.M. 1980. Considerações sobre o Conceito de Camadas do Ponto de Vista Geotécnico, na Bacia de São Paulo. In: MESA REDONDA SOBRE ASPECTOS GEOLÓGICOS E GEOTÉCNICOS DA BACIA SEDIMENTAR DE SÃO PAULO. São Paulo, 1980. Publicação Especial. São Paulo, SGB/NSP. p.47-52.

COzZOLINO, V.M. 1992. Perfil Geotécnico ao Longo do Túnel da ELETROPAULO entre a Várzea do Glicério e a Ponte de Vila Guilherme - Aspecto da construção do túnel em areias do Terciário de São Paulo. Solos e Rochas, 15(1):133-29.

COZzOLINO, V. M. \& NOGAMI, J.S. 1994.Classificaçào Geotécnica MCT para Solos Tropicais. Solos e Rochas, 16(2):77-91. 
COzZolino, V.M.; MARTINATI, L.R.; BUONO, A.V.D. 1994. Contribuição ao Estudo dos Movimentos Tectônicos Sin e Pós-Sedimentares na Bacia de São Paulo a partir de Evidências Observadas nas Escavações do Túnel da ELETROPAULO. Solos e Rochas, 17(1):13-29.

CROSTA, A.P. 1982. Estruturas de Impacto no Brasil: uma síntese do conhecimento atual. In: CONGRESSO BRASILEIRO DE GEOLOGIA, 32. Salvador, 1982. Anais... São Paulo, SBG. v.4, p.1372-1377.

DECOURT, L. 1992. Fundaçōes Rasas. In: NEGRO Jr, A; FERREIRA, A.A.; ALONSO, U.R; LUZ, P.A.C. - eds. Solos da Cidade de São Paulo. São Paulo, ABMS/ABEF. p.217-228.

DEFFONTAINES, P. 1935. Regiões e Paisagens do Estado de São Paulo: primeiro esboço de visão regional. Geografia l, (2):117-169.

EMPRESA METROPOLITANA DE PLANEJAMENTO DA GRANDE SÃo PAULO - EMPLASA 1981. Levantamento planimétrico, escala 1:25.000.

FERREIRA, A . A .; ROCHA, H. C.; NETO L. A. 1987. Algumas Correlações do Índice de Suportes e Parâmetros de Compactação para Solos da Região Metropolitana de São Paulo. In: REUNIÃo ANUAL DE PAVIMENTAÇÃO, 22. Maceió, 1987. Atas... Maceió, Associação Brasileira de Pavimentação. v.1, p.902-929.

FORTES, R.M. 1990. Método Expedito de Identificação de Solos Tropicais para Finalidades Rodoviárias, Utilizando-se Anéis de PVC Rigido. Dissertação de Mestrado apresentada à Escola PolitécnicaUniversidade de São Paulo. São Paulo. 195p.

FORTES, R.M. \& NOGAMI, J.S. 1991. Método Expedito de Identificação do Grupo MCT de Solos Tropicais Utilizando-se Anéis de PVC Rígido. In: REUNIÃO ANUAL DE PAVIMENTAÇÃO, 25. Rio de Janeiro, 1991. Atas... São Paulo, ABPV. v. 1, p. 591-604.

GARCIA, M.J. 1994. Palinologia de Turfeiras Quaternárias do médio vale do Rio Paraíba do Sul, Estado de São Paulo. Tese de Doutoramento. Instituto de Geociências - Universidade de São Paulo. São Paulo. $3 \mathrm{v}$.

GEOLOGICAL SOCIETY ENGENERRY GROUP WORKING PARTY REPORT-TROPICAL RESIDUAL SOILS. The Quaternaly Journal, Engeneering Geology, 23(1):101p.

GIACHETI, H.L.; ZUQUETTE, L.V.; CORDEIRO, R.P. \& DOURADO, J.C. 1993. Parâmetros Dinânicos de Solos Tropicais. In: SEMINÁRIO CIÊNCIAS EXATAS E ENGENHARIA, 12. Guaratinguetá, 1993. Anais... Guaratinguetá, ADUNESP. p.241-245.

GODOY, H.; BERMUCCI, L.B.; NOGAMI, J.S. 1996. Diretrizes para Identificação Expedita de Solos Lateriticos para Uso em Obras Viárias. In: REUNIÃO ANUAL DE PAVIMENTAÇÃO, 30. Salvador, 1996. Anais... Salvador, ABPV. p. 556-568.

HASUI, Y. \& SADOWSKI, G. R. 1976. Evolução Geológica do Pré-Cambriano da Região Sudeste do Estado de São Paulo. Revista Brasileira de Geociências, 6:182-200.

HASUI, Y.\& CARNEIRO, C.D.R 1980. Origem e Evolucão da Bacia Sedimentar de São Paulo. In: Mesa Redonda: Aspectos Geológicos e Geotécnicos da Bacia Sedimentar de São Paulo. São Paulo, 1980. Publicação Especial. São Paulo, ABGE/SBG-SP. p. 47-52. 
HASUI, Y.; CARNEIRO, C.D.R.; COIMBRA, A.M. 1975. The Ribeira Folded Belt. Revista Brasileira de Geociências, 5:257-266.

HUECK, K.1965. A Região das Matas Subtropicais do Leste e Sul do Brasil. In: HUECK, K. As Florestas da América do sul: ecologia, composição e importància econômica. São Paulo, Polígono. P.183-239.

IGNATIUS, S.G. 1991. Solos Tropicais: proposta de índice classificatório. Solos e Rochas, 14 (2): 89-93.

INSTITUTO BRASILEIRO DE GEOGRAFIA E ESTATÍSTICA - IBGE 1991. Sinopse preliminar do Censo Demográfico. São Paulo. 233p.

INSTITUTO de PESQuisas TeCNOlógicas do ESTAdo de SÃo PAUlo S/A - IPT 1981. Mapa Geomorfológico do Estado de São Paulo. v.1, 94p.

INSTITUTO de PESQUiSAS TECNOLÓGICAS DO ESTAdo de SÃo PAULO S/A - IPT 1986. Tectônica e Sedimentação Cenozóica na Área da Soleira Entre as Bacias de São Paulo e Taubaté. Relatório 23.72t, 2v., São Paulo.

JUNQUEIRA, C.B. 1969. Camadas Cruzadas de Areias, Gravas e Cascalhos Fluviais do Vale do Pinheiros ("campus" da Cidade Universitária). Boletim do Instituto de Geografia da (Iniversidade de São Paulo (Série Geomorfologia), 10:7-9.

KOLLERT, R.; BJÖRNBERG, A.; DAVINO, A. 1961. Estudos Preliminares de Uma Depressão Circular na Região de Colônia: Santo Amaro, São Paulo. Boletim da Sociedade Brasileira de Geologia, 10:5777.

LANDIM, P. M. B. \& POTTER, P. E. 1995. Geologia Urbana: uma proposta curricular. In: SIMPÓSIO DE GEOLOGIA DO SUDESTE, 4. Águas de São Pedro, 1995. Boletim de resumos... Águas de São Pedro, UNESP. p. 84.

LANDIM, P. M. B. \& POTTER, P. E. 1996. Urban geology-how teaching it helps everyone. Geoscience and Development, (3):22.

LECOMTE, P. 1988. Stone-Line Profiles: Importance in Geochemical Exploration. J. Geochem Explor., $30: 35-61$.

LEDRU, M.P. 1991. Etude de la pluie pollinique achielle des forêts du Brésil central: climat, végétation, application à l'étude de l'évolution paléoclimatique des 30000 dernières années. Presenteé pour l'obtencion du Diplôme de Doctorat, Institut de Paleontologie Humaine, Museu National d'Histoire Naturelle. França. 193p.

LEDRU, M.P. 1993. Late Quaternary Environmental and Climatic Charges in Central Brazil. Quartenary Reserch, 39:90-98.

LIMA, M.R. \& DINO, R. 1985. Palinologia de Amostras da Bacia de Bonfim, Terciário do Estado de São Paulo, Brasil. Anais da Academia Brasileira de Ciências, 56:112.

LIMA, M.R. \& MELO, M.S. 1989. Palinologia de Sedimentos da Bacia de São Paulo. In: WORKSHOP GEOLOGIA DA BACIA DE SÃO PAULO. São Paulo, 1989. Coletânia dos trabalhos... São Paulo, SBG. p. 35-37. 
LIMA, M.R.; SUGUIO, K.; VESPUCCI, J.B.O. 1985. Estudo Palinológico de Uma Camada de Linhito da Formação Caçapava. Bacia de Taubaté, Terciário do Estado de São Paulo, Brasil. Anais da Academia Brasileira de Ciências, 57:183-197.

LIMA, M.R.; RICCOMINI, C.; SOUZA, P.A. 1994. Palinologia de Folhelhos do Gráben de Casa de Pedra, Terciário do Estado do Rio de Janeiro, Brasil. Acta Geológica Leopoldensia, 39(2):485-504.

LORSCHEITTER, M.L.; TURCQ, B.; RICCOMINI, C. 1990. Palinologia de Sedimentos Paludosos de Colônia, São Paulo. Paleobotanica Latino-americana, 9: 26.

MANCINI, F.\& RICCOMINI, C. 1994. Estilos Estruturais da Formação Pindamonhangaba, Bacia de Taubaté, SP. In: CONGRESSO BRASILEIRO DE GEOLOGIA, 38. Camboriú, 1994. Resumos expandidos... Camboriú, SBG. v.1, p.564-565.

MASERO, W.C.B. \& FONTES, S.L. 1991. Audiomagnetotelluric Investigations of Colônia Depression, São Paulo - Brazil. In: CONGRESSO INTERNACIONAL DA SOCIEDADE BRASILEIRA DE GEOFÍSICA, 2. Salvador, 1991. Anais... Salvador, SBGf. v.1, p.317-322.

MAWE, J. 1812. Descrição de São Paulo. Sistema de Cultura nos seus Arredores - Excursões às Minas de Ouro do Jaraguá - Métodos de Mineração nelas Empregados - Volta á Santos. In: Viagens ao Interior do Brasil. São Paulo. Ed.USP. p. 63-74. Trad. Selena Benevides Viana.

MELLO, C.L. 1992. Fácies Sedimentares, Arquitetura Deposicional e Relações Morfoestratigráficas em um Sistema de Leques Aluviais Holocênicos: Aloformação Manso-Médio Vale do Rio Paraíba do Sul (SP/RJ). Dissertação de Mestrado apresentada ao Departamento de Geologia - IGEO/UFRJ, Rio de Janeiro. 188p.

MELlO, C.L.; MOURA, J.R.S.; CARMO, I.O.; SILVA, T.M.; PEIXOTO, M.N.O. 1995. Eventos de Sedimentação Durante o Holoceno no Médio Vale do Rio Paraíba do Sul (SP/RJ) - Aloestratigrafia e Dataçōes por Radiocarbono. In: CONGRESSO DA ASSOCIAÇÃO BRASILEIRA DE ESTUDOS DO QUATERNÁRIO, 5. Niterói, 1995. Alas... Niterói, ABEQUA. p. 193-200.

MELO, M.S.; RICCOMINI, C.; HASUI, Y. ; ALMEIDA, F.F.M.; COIMBRA, A.M. 1985. Geologia e Evolução do Sistema de Bacias Tafrogênicas Continentais do Sudeste do Brasil. Revista Brasileira de Geociências. 15: 193-201.

MElO, M.S.; CAETANO, S.L.V.; COIMBRA, A.M. 1986. Tectônica e Sedimentação na Área das Bacias de São Paulo e Taubaté. In: CONGRESSO BRASILEIRO DE GEOLOGIA, 34. Goiânia, 1986. Atas... Goiânia, SBG. v.1, p.321-336.

MELO, M.S.; PONÇANO, W.L.; MOOK, W.G.; AZEVEDO, A.E.G. 1987. Datações ${ }^{14} \mathrm{C}$ em Sedimentos da Grande São Paulo. In: CONGRESSO DA ASSOCIAÇÃO BRASILEIRA DE ESTUDOS DO QUATERNÁRIO, 1. Porto Alegre, 1987. Atas... Porto Alegre, ABEQUA. p.427-436.

MELO, M.S.; FERNANDES, L.A.; COIMBRA, A.M.; RAMO, R.G.N. 1989a . O Gráben (Terciário?) de Sete Barras, Vale do Ribeira, SP. Revista Brasileira de Geociências, 19:260-262.

MElo, M.S.; COIMrRA, A.M.; RICCOMINI, C. 1989b. Evolução dos Conhecimentos Sobre a Geologia da Bacia de São Paulo na Década de Oitenta. In: WORKSHOP GEOLOGIA DA BACIA DE SÃO PAULO. São Paulo, 1989. Coletânea de Trabalhos... São Paulo, SBG. p.1-11.

MENDES, J.C. 1950. O Problema da Idade das Camadas de São Paulo. Boletim Paulista de Geografia, 5:45-48. 
MEZZALIRA, S. 1962. Novas Ocorrências de Vegetais Fósseis Cenozóicos no Estado de São Paulo. O Instituto Geográfico e Geológico, 15:73-94.

MIOTO, J.A. 1993. Sismicidade e Zonas Sismogênicas do Brasil. Tese de Doutoramento. Instituto de Geociências e Ciências Exatas-UNESP. Rio Claro. 2v: 276p.-282p.

MOHRIAK, W.U. \& BARROS, A.Z.N. 1990. Novas Evidências de Tectonismo Cenozóico na Região Sudeste do Brasil: o Gráben de Barra de São João na Plataforma de Cabo Frio, RJ. Revista Brasileira de Geociências, 20:187-196.

MONBEIG, P. 1949. A divisão regional do Estado de São Paulo. Anais da Associação dos Geográfos Brasileiros, (1):19-30.

MORAES REGO, L.F. 1930. A Geologia do Petróleo no Estado de São Paulo. Boletim do Serviço Geológico e Mineralógico do Brasil, 46:65-70.

MORAES REGO, L.F. 1932. Notas sobre a geomorfologia de São Paulo e sua gênesis. Instituto Astronômico e Geofisico. 43p.

MORAES REGO, L.F. 1933. As Formações Cenozóicas de São Paulo. Anuário da Escola Polytecnica, 2: 231-267.

MOURA, J.R.S.; MELLO, C.L.; BARROS, M.A . \& FIOCRUZ, O .M.B. 1993. O Limite PleistocenoHoloceno no Médio Vale do Paraíba do Sul. In: CONGRESSO DA ASSOCIAÇÃO BRASILEIRA DE ESTUDO DO QUATERNÁRIO, 4. São Paulo, 1993. Resumos... São Paulo, ABEQUA. p.15-16

MOUSINHO, M.R. \& BIGARELLA, J.J. 1965. Movimentos de Massa no Transporte dos Detritos da Meteorização da Rochas. Boletim Paranaense de Geografia, (16-17).

MULDER, E.F.J. 1993. Urban Geology in Europe: an overview. In: BOBROWSKY, P.T. \& LIVERMAN, D.G.E. (Guest Editors). Quaternary International, 20:5-11.

NOGAMI, J.S. \& VILLIBOR, D.F. 1980. Caracterização e classificação gerais de solos para pavimentação: limitações do método tradicional, apresentação de uma nova sistemática. In: REUNIÃO ANUAL DE PAVIMENTAÇÃO, 15. Belo Horizonte, 1980. Atas... Belo Horizonte, ABPV. p. 1-38.

NOGAMI, J.S. \& VILLIBOR, D.F. 1981. Uma Nova Classificação de Solos para Finalidades Rodoviárias. In: SIMPÓSIO BRASILEIRO DE SOLOS TROPICAIS EM ENGENHARIA. Rio de Janeiro, 1981. Atas... Rio de Janeiro, COPPE/UFRJ/RJ. v.1, p.30-41.

NOGAMI, J.S. \& COZZOLINO, V.M. 1985. Identificação de solos tropicais: dificuldades e proposta de um método preliminar. In: REUNIÃo ANUAL DE PAVIMENTAÇ̃̃o, 20. Rio de Janeiro, 1985. Atas... Rio de Janeiro, ABPV. v.1, p.115-134.

NOGAMI, J.S. \& VILLIBOR, D.F. 1994. Identificação Expedita dos Grupos da Classificação MCT para Solos Tropicais. In: CONGRESSO BRASILEIRO DE MECÂNICA DE SOLOS E ENGENHARIA DE FUNDAÇÕES, 5. Foz do Iguaçu, 1994. Atas... Foz do Iguaçu, ABGE/ABMS. v.2 p.1293-1300.

NOGAMI, J.S. \& VILLIBOR, D.F. 1996. Importância e Determinação do Grau de Laterização em Geologia de Engenharia. In: CONGRESSO BRASILEIRO DE GEOLOGIA DE ENGENHARIA, 8. Rio de Janeiro, 1996. Atas... Rio de Janeiro, ABGE. 345-358p. 
OLIVEIRA, A.M.S. 1990. Depósitos Tecnogênicos Associados a Erosão Atual. In: CONGRESSO BRASILEIRO DE GEOLOGIA DE ENGENHARIA / IX COBRAMSEF, 6. Salvador, 1990. Atas... Salvador, ABGE/ABMS. p.411-419.

OLIVEIRA, P.E. 1992. A Palynological Record of Date Quaternary Vegetational and Climatic Change in Southeastern Brazil.. Dissertation presented in partral fulfielment of the Requirements for the degree Doctor in the graduate school of the Ohio State University. Ohio, EUA.

PELOGGIA, A.U.G. 1994. As Coberturas Remobilizadas: depósitos tectogênicos de encostas urbanas no município de São Paulo. Solos e Rochas, 17 (2):125-129.

PISSIS, A. 1842a . Considérations Générales Sur Les Terrains Du Brésil. Bulletin de la Societé Géologique de France. 13:282-290.

PISSIS, A. 1842b. Mémoire sus la Position Géologique des Terrains de la Parte Australe du Brésil et sur les Soulevements qui, à Diverses Époques, ont Change le Relief de Cette Contres. Compte Rendus de la Academie des Sciences, 14:353-413.

PlAiSANCE, G. \& CAILlEUX, A. 1958. Dictionnaire des Soils. La Maison Rustique. Paris. 607p.

PREFEITURA DO MUNICÍPIO DE SÃO PAULO - SECRETARIA DE ADMINISTRAÇÕES REGIONAIS - COURGE. 1995. Áreas de Risco do Município de são Paulo - Setembro/94 a Março/95. SAR/COURGE. 72p.

PREFEITURA dO MUNICÍPIO DE SÃo PAULO (1930) Mapa Topográfico do Município de São Paulo. Projeto SARA BRASIL, escala 1:5.000, 72 folhas.

PREFEITURA do MUNiCÍPIO DE SÃo PAULO - SECRETARIA DA HABITAÇÃo E DESENVOLVIMENTO IRBANO 1994. Favelas na Cidade de São Paulo. Relatório Gerencial. (D.O.M. de março de 1995). 40(10):2-12.

PREFEITURA do MUNICÍPIO de SÃo PAULO - SECRETARIA de VIAS PÚbliCAS LIMPURB 1996. Relatório Gerencial, 25. LOGOS ENGENHARIA. 74p.

PREFEITURA DO MUNICÍPIO DE SÃO PAULO - SECRETARIA DO VERDE E DO MEIO AMBIENTE 1996. Agenda 21 Local: Compromisso do Município de São Paulo. CADES, São Paulo.

RICCOMINI, C. 1989. O Rifi Continental do Sudeste do Brasil. Tese de doutoramento. Instituto de Geociências - Universidade de São Paulo. São Paulo. 256p.

RICCOMINI, C. \& COIMBRA, A.M. 1992. Geologia da Bacia Sedimentar. In: NEGRO Jr, A.; FERREIRA, A.A.; AlONSO, U.R.; LUZ, P.A.C. (eds) Solos da Cidade de São Paulo. São Paulo, ABMS/ABEF. p.37-94.

RICCOMINI, C.; COUTINHO, J.M.; GUARANÁ, C.A.; COIMBRA, A.M.; HACHIRO, J.; ATENCIO, D.; IOMASA, W.W. 1988. Evidências de Hidrotermalismo em Sedimentos da Bacia de são Paulo: Considerações Genéticas. Anais da Academia Brasileira de Ciências (resumos), 60:105-106.

RICCOMINI, C.; TURCQ, B.; MARTIN, L. 1989. The Colonia Astrobleme. In: INTERNATIONAL SYMPOSIUM ON GLOBAL CHANGES IN SOUTH AMERICA DURING THE QUATERNARY. São Paulo, 1989. Excursion field guide... São Paulo, INQUA. 14p. 
RICCOMINI, C.; TURCQ, B.; SUGUIO, K. 1991a. The record of continental sedimentation in southeastern Brazil during the last millenniun: paleoseismicity, the Little Ice Age, and man. Anais da Academia Brasileira de Ciências, 63:90.

RICCOMINI, C.; TURCQ, B.; MARTIN, L.; MOREIRA, M.Z.; LORSCHEITTER, M.L. 1991b. The Colônia Astrobleme, Brazil. Revista do Instituto Geológico, 12:9-25.

RiCCOMINI, C.; PEllogia, A.U.G.; SAloni, J.C.L.; KOHNKE, M.W. \& FIGUEIRA, R.M. 1989. Neotectonic Activity in the Serra do Mar Rift System. Journal of South American Earth Sciences, 2:191-197.

RICCOMINI, C.; SANT'ANNA, L.G.; COIMBRA, A.M. 1996. Paleogene Paleoclimates. In: Southeastern Brazil: evidence from clay minerals. In: INTERNATIONAL GEOLOGICAL CONGRESS, 30. Beijing, 1996. Abstracts... Beijing, IUGS. vol.2 of 3, p.172.

ROCHA, H.C. 1995. Algumas Características dos Solos Arenosos Terciários de São Paulo e suas Implicações em obras subterrâneas. Dissertação de Mestrado apresentada a Escola de Engenharia de São Carlos da Universidade de São Paulo. São Carios. 136p.

ROCHA, H.C. \& CELESTINO, T.B. 1992. Conhecimentos Recentes Sobre a Bacia de São Paulo e o Projeto de Construções de Túneis. In: PROBLEMAS GEOLÓGICOS E GEOTÉCNICOS NA REGIÃo METROPOLITANA DE SÃO PAULO. São Paulo, 1992. Coletânia de trabalhos... São Paulo, ABAS/ABGE/SBG/SP. p.97-114.

ROCHA, J.C.S. 1993. Caracteristica Geologica-Geotécnica dos Materiais Envolvidos nos Movimentos de Massa Ocorridos em Fev/88, na vista Chinesa RJ/RJ. Dissertação de Mestrado apresentado ao Instituto de Geociências na Universidade Federal do Rio de Janeiro. Rio de Janeiro. 163p.

RODRIGUEZ, S.K. 1993. Neotectônica e Sedimentação Quaternária da Região da "Volta Grande" do rio Xingu, Altamira, PA. Dissertação de mestrado apresentado ao Instituto de Geociências da Universidade de São Paulo. São Paulo. 106p.

RODRIGUEZ, S.K. 1994. Comentários a Respeito de Depósitos Stone Lines. In: CONGRESSO BRASILEIRO DE GEOLOGIA, 38. Camboriú, 1993. Resumos expandidos.. Camboriú, SBG. p.189190.

ROLNIK, R.; KOWARIK, L. SOMEKH, N. s/d. São Paulo: crise e mudança. 2 Ed. São Paulo, Brasiliense. 215p.

SABESP/CEPAS 1993. Diagnóstico da Região Metropolitana de São Paulo. Base hidrogeológica, 1:50.000 (Equipe Técnica: REBOUÇAS, A.C.; RICCOMINI, C.; ELLERT, N.; DUARTE, U.; MELLITO, K.M.; SENF, L.A.). Convênio Companhia de Saneamento Básico - SABESP/Centro de Pesquisas de Águas Subterrâneas - CEPAS.

SADOWSKI, G.R. 1983. Sobre a Geologia Estrutural de Cinturões de Cisalhamento Continentais. Tese de livre-docência. Instituto de Geociências - Universidade de São Paulo. São Paulo. 108p.

SADOWSKI, G.R. 1991. A Megafalha de Cubatão no Sudeste Brasileiro. Boletim do Instituto de Geociências da Universidade de São Paulo (Série Científica), 22: 5-28.

SADOWSKI, G.R. \& MOTIDOME, M.J. 1987. Brazilian megafaults. Revista Geológica do Chile, 31:6175 . 
SALVADOR, E.D. 1994. Análise Neotectónica da Região do Vale do Rio Paraíba do Sul Compreendida entre Cruzeiro (SP) e ltatiba (RJ). Dissertação de mestrado apresentada ao Instituto de Geociências Universidade de São Paulo, São Paulo. 129 p.

SALVADOR, E.D. \& RICCOMINI, C. 1995. Direção dos esforços na Soleira de Queluz (SP-RJ), Brasil. Anais da Academia Brasileira de Ciências, 67:135.

SALVADOR, E. D. \& RICCOMINI, C. no prelo. Neotectônica da Região do Alto Estrutural de Queluz (SP-RJ, Brasil ). Revista Brasileira de (ieologia.

SANT'ANNA, L. G. \& VALARELLI, J. V. 1996. Significado Paleoclimático das Halloisitas da Formação Tremembé, Bacia de Taubaté, SP. In: CONGRESSO BRASILEIRO DE GEOLOGIA, 39. Salvador, 1996. Anais... Salvador, SBG. v.1, p.230-231.

SECRETARIA DE HABITAÇÃO E DESENVOLVIMENTO URBANO - SEHAB 1995. Programa de Verticalização e Urbanização de Favelas. Projeto Cingapura. Paper apresentado no Seminário para preparação brasileira à segunda Conferência da Nações Unidas para os assentamentos urbanos. 27 e 28 de julho de 1995. São Paulo.

SERVANT, M.; FOURNIER, M.; SOUBIÉS, F.; SUGUIO, K.; TURCQ, B. 1989. Sécheresse holocene au Brésil (18-20 latitude Sud.). Implications paléométéorologiques. Compte Rendus de la Académie des Sciences, 30(2):153-156.

SíGOLO, J.B. \& OHNUMA, C.S. 1991. As Couraças Ferruginosas de Recobrimento da Bacia de São Paulo. Sua Distribuição e Composição Lito-Mineralógica. Resultados preliminares. Boletim do Instituto de Geociências da Universidade de São Paulo, (Publicação Especial), 9:157-162.

SOCIEDADE BRASILEIRA DE GEOLOGIA, NÚCLEO SÃO PAULO E RIO DE JANEIRO 1991 SIMPÓSIO DE GEOLOGIA DO SUDESTE, 2. São Paulo, 1991. Atas... São Paulo, SBG/NSP-RJ. $546 \mathrm{p}$.

SOCIEDAde BRASIleira DE GEOLOGIA, NÚCleO SÃo PAULO 1992. CONGRESSO BRASILEIRO DE GEOLOGIA, 37. São Paulo, 1992. Boletim de Resumos Expandidos... São Paulo, SBG/NSP. v1, 629p.

SOCIEDADE BRASILEIRA DE GEOLOGIA, NÚCLEO SÃo PAULO E RIO DE JANEIRO 1993. SIMPÓSIO DE GEOLOGIA DO SUDESTE, 3. São Paulo, 1993. Atas... São Paulo, SBG/NSP-RJ. $332 \mathrm{p}$.

SÓRIA, M. H. A . 1986. Os Limites de Atterberg, o Argilomineral. In: CONGRESSO BRASILEIRO MECÂNICA DE SOlos E ENGENHARIA DE FUNDAÇÃO, 8. Porto Alegre, 1986. Anais... Porto Alegre, ABMS. v.1, p.161-171.

STOCKMARR, J. 1971. Tablets with spores used in absolute pollen analysis. Pollen et Spores, 13: 615621.

STRAHLER, A. N. 1952. Dynamic basis of geomorfology. Geol. Soc. Am. Bull. 63:923-938,

SUGUIO, K. 1971. Estudos doas Troncos de Árvores "Linhitificados" dos Aluviões Antigos dos Rio Pinheiros (São Paulo), Significado Geocronológico e Possivelmente Paleoclimático. In: CONGRESSO BRASILEIRO DE GEOLOGIA, 25. São Paulo, 1971. Anais... São Paulo, SBG. v. 1, p.63-65. 
SUGUIO, K. \& BARBOUR, A.P. 1969. Morfologia e Gênese das Estruturas Limoniticas dos Sedimentos da Bacia de São Paulo. Anais da Academia Brasileira de Ciências, 41:161-180.

SUGUIO, K. \& TAKAHASHI, L.I. 1970. Estudo dos Aluviões Antigos dos Rios Pinheiros e Tietê, São Paulo, SP. Anais da Academia Brasileira de Ciencias, 42:555-570.

SUGUIO, K. \& MUSSA, D. 1978. Madeiras fósseis dos Aluviões Antigos dos Rios Pinheiros e Tietê, São Paulo, SP. Boletim do Instituto de Geociências da Universidade de São Paulo (Série Cientifica), 9:2545 .

SUGUIO, K.; COIMBRA, A.M.; MARTINS, C.; BARCELOS, J.H.; GUARDADO, L.R. RAMPAZzO, L. 1971. Novos Dados Sedimentológicos dos Aluviões Antigos do Rio Pinheiros (São Paulo) e seus Significados na Interpretação do Ambiente Deposicional. In: Congresso Brasileiro de Geologia, 25. São Paulo, 1971. Atas... São Paulo, SBG. v.2, p.219-225.

TAKIYA H. 1991. Aplicação de métodos quantitativos espaciais a dados geológicos da Bacia de São Paulo. Dissertação de mestrado apresentado ao Instituto de Geociências da Universidade de São Paulo. São Paulo. 109p.

TAKIYA, H. \& YBERT, J.P. 1991. Evidência Palinológica de Uma Fase Climática Seca Durante o Holoceno na Bacia de São Paulo. In: SIMPÓSIO DE GEOLOGIA DO SUDESTE, 2. São Paulo, 1991. Resumos... São Paulo, SBG/NSP/RJ. p.29-30.

TAKIYA, H.; PELOGGIA, A.U.G.; TOKUTAKE, L.R.; CAMPOS, J.E.; OGAWA, A.T.; KOGA, H.; MISAWA, W.J.; RICCOMINI, C. 1989. Arcabouço estrutural da Bacia de São Paulo. In: WORKSHOP GEOLOGIA DA BACIA DE SÃO PAULO. São Paulo, 1989. Coletânea dos Trabalhos... São Paulo, SBG. p.16-27.

TURCQ, B. \& MELO, M.S. 1989. O Quaternário na Área da Grande São Paulo. In: WORKSHOP GEOLOGIA DA BACIA DE SÃO PAULO. São Paulo, 1989. Coletâneas... São Paulo, ABAS/ABGE/SBG. p.64-70.

TURCQ, B.; RICCOMINI, C.; FOURNIER, M.; MARTIN, L.; MOREIRA, M.Z.; SUGUIO, K. 1989. Sedimentação quaternária no Astroblema de Colônia, SP. In: CONGRESSO DA ASSSOCIAÇÃO BRASILEIRA DE ESTUDOS DO QUATERNÁRIO, 2. Rio de Janeiro, 1989. Resumos... Rio de Janeiro, ABEQUA. p.39-49.

TURCQ, B.; SUGUIO, K.; SALGADO-LABOURIAU, M.L.; FERRA-VICENTINI, K.; LORSCHEITTER, M.L.; MARTIN, L.; PRESSINOTTI, M.M.N.; RICCOMINI, C. 1993. Os significados Paleoclimáticos dos Depósitos Orgânicos dos Últimos 30.000 anos no Brasil Central. In: CONGRESSO DA ASSOCIAÇÃO BRASILEIRA DE ESTUDOS DO QUATERNÁRIO, 4. São Paulo, 1993. Resumos... São Paulo, ABEQUA. p.7.

TURCQ, B.; SUGUIO, K.; ABSY, M.L.; LEDRU, M.P.; LORSCHEITTER, A.L.; MARTIN, L.; RICCOMINI, C.; SAlGADO-LABORIAU, M.L.; SERVANT, M.; SIFEDDINE, A.; SOUBIES, F. 1995. Climas Pleistocênicos no Brasil. In: CONGRESSO DA ASSOCIAÇÃO BRASILEIRA DE ESTUDOS DO QUATERNÁRIO. Niterói, 1995. Resumos... Niterói, ABEQUA. p. 28-31.

TURCQ, B.; ALBUQUERQUE, A .L. S.; LEDRU, M. P.; MELLO, C. L.; PRESSINOTTI, M. M. N.; RICCOMINI, C.; SUGUIO, K. 1996. Transição Pleistoceno-Holoceno na Regiào Sudeste Brasileira. In: CONGRESSO BRASILEIRO DE GEOLOGIA, 39. Salvador, 1996. Anais... Salvador, SBG. v.4, p.507-509. 
UESSUGUI, N. 1979. Técnicas de tratamento de amostras. Boletim Técnico Petrobrás, 22(4):229-240.

VARGAS, M. 1953. Problemas de Fundação de Edifícios em São Paulo e Sua Relação Com a Formação Geológica Local. In: CONGRESSO DA ASSOCIAÇÃO BRASILEIRA DE MECÂNICA DOS SOLOS. São Paulo, 1953. Anais... São Paulo, ABMS. vol.III.

VARGAS, M. 1982. O uso dos limites de Attemberg na Classificação dos Solos Tropicais. In: CONGRESSO BRASILEIRO DE MECÂNICA DE SOLOS E ENGENHARIA DE FUNDAÇÕES. Olinda, 1982. Atas... Olinda, ABMS. v.5, p.262-278.

VERTAMATTI, E. 1988. Contribuição ao Conhecimento Geotécnico de Solos da Amazònia com Base na Investigação de Aeroportos e Metodologias MCT e Resiliente. Tese de doutoramento. ITA - São José dos Campos. 276p.

WOlle, C.M. \& CARVALHo, C.S. 1989. Deslizamentos em Encostas na Serra do Mar-Brasil. Solos $e$ Rochas, (12):27.35.

YAMAMOTO, I.T.1995. Palinologia das Bacias Tafrogênicas do Sudeste (Bacias de Taubaté, São Paulo $e$ Resende): análise bioestratigráfica integrada e interpretação paleoambiental. Dissertação de Mestrado, apresentado ao Instituto de Geociências e Ciências Exatas de Rio Claro - UNESP, Rio Claro. $217 \mathrm{p}$.

YBERT, J.P.; SALGADO LABORIAU, M.L; BARTH., O.M.; LORSCHEITTER, M.L.; BARROS, M.A.; CHAVES, S.A.M.; LUZ, C.F.P.; RIBEIRO, M.; SCHEEL, R.; VICENTINI, K.F. 1992. Sugestões para Padronização da Metodologia Empregada em Estudos Palinológicos do Quaternário. Revista do Instituto Geológico 13 (2):47-49. 


\section{APÊNDICE}




$\begin{array}{lc}\text { LEGENDA DOS DIFRATOGRAMAS DE RAIOS X: } \\ \text { s-esmectita } & \text { cor azul - amostra aquecida } \\ k \text { - caulinita } & \text { cor verde - amostra glicolada } \\ m \text { - mica } & \text { cor cinza - amostra natural } \\ f \text { - feldspato } & \end{array}$
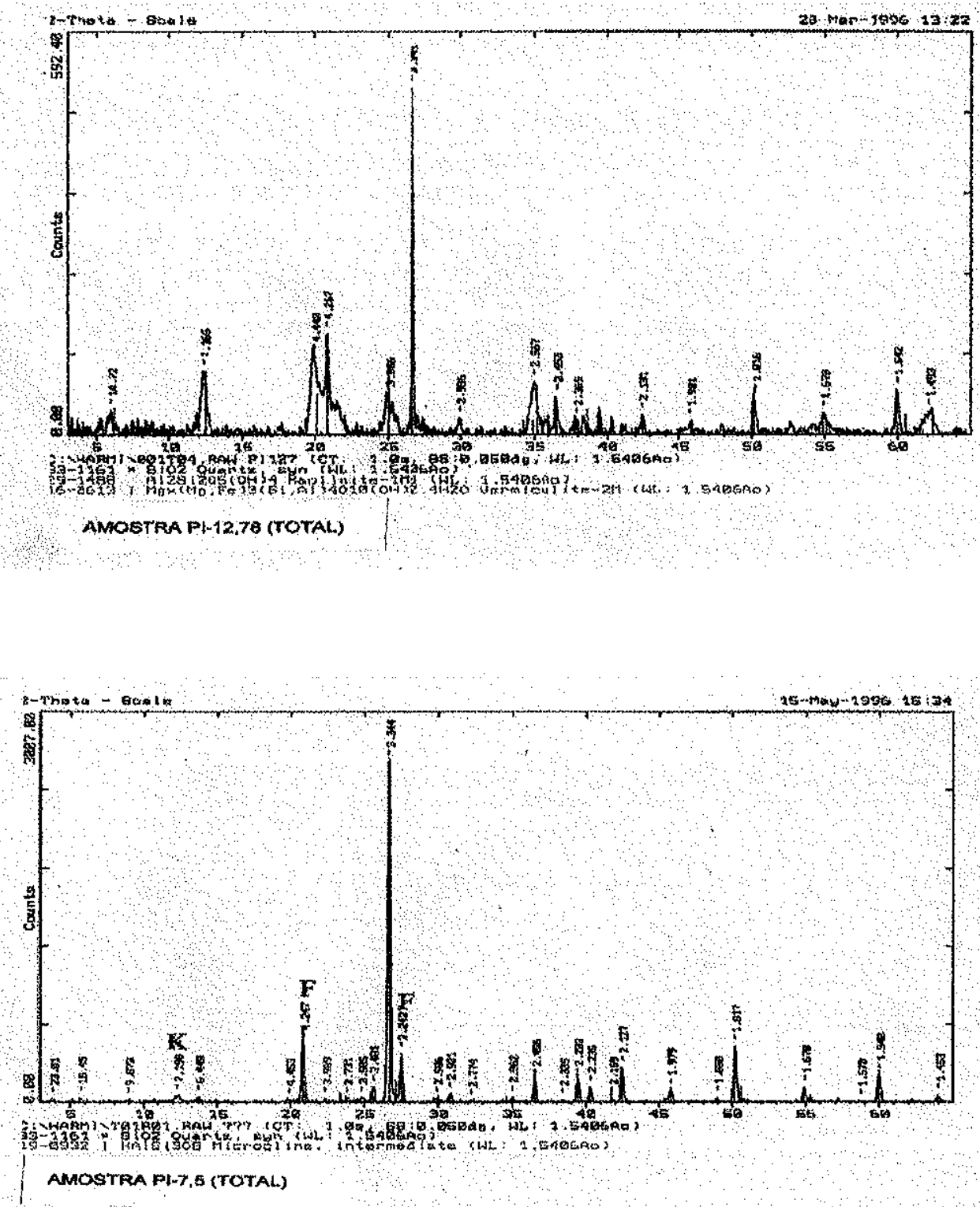

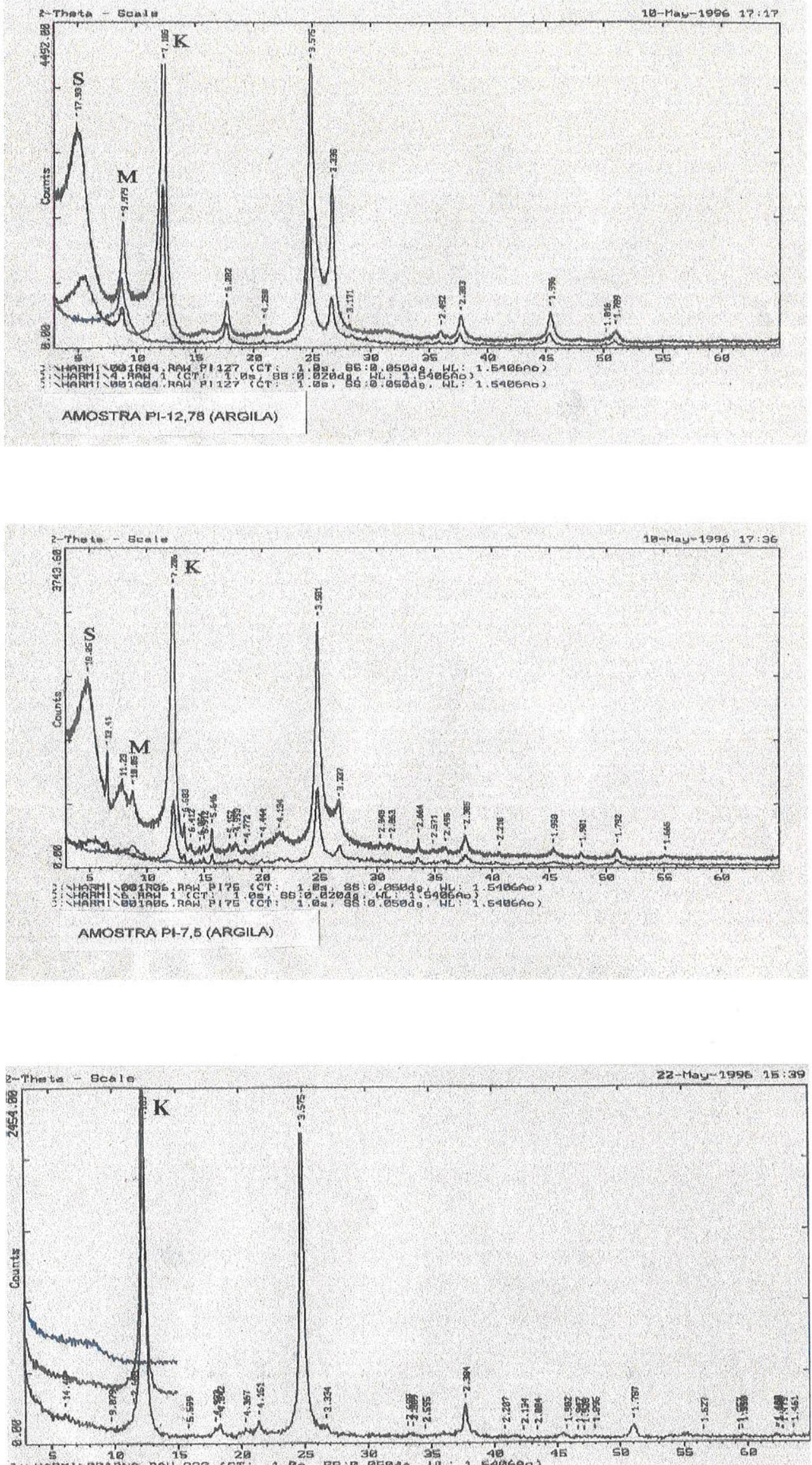

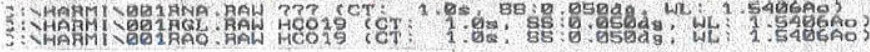

AMOSTRA H-CO-19 (ARGILA) 


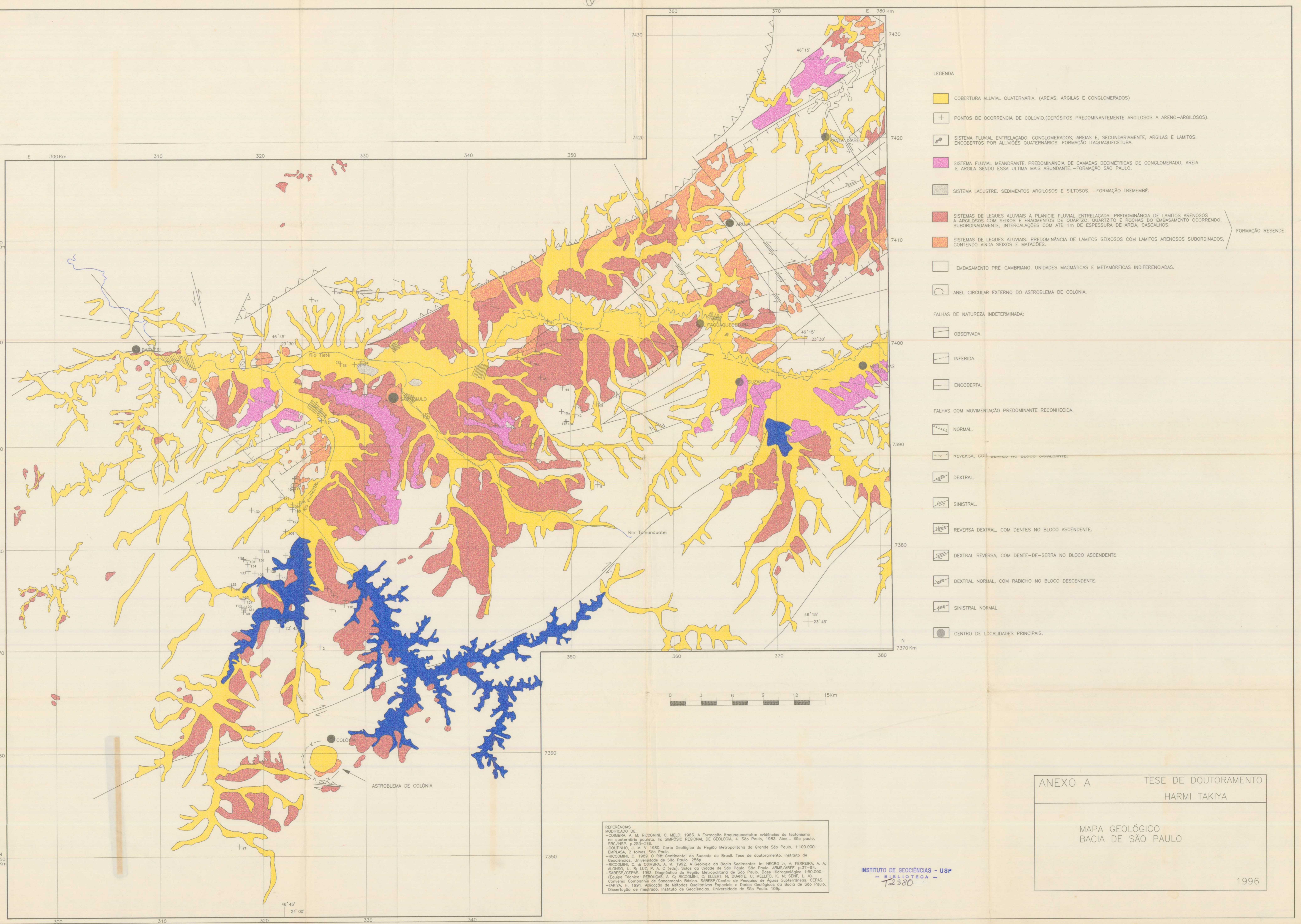


Perfil de sondagens jusante-montante do Córrego Franquinho.

$765 \mathrm{~m}$

\begin{tabular}{ll}
$760 \mathrm{~m}$ & $\overline{0}$ \\
$755 \mathrm{~m}$ & $\stackrel{\overline{0}}{\bar{D}}$ \\
\hline &
\end{tabular}

$750 m$ :

$745 \mathrm{~m}$

$740 \mathrm{~m}$

$730 \mathrm{~m}$

$725 \mathrm{~m}$

$720 \mathrm{~m}$

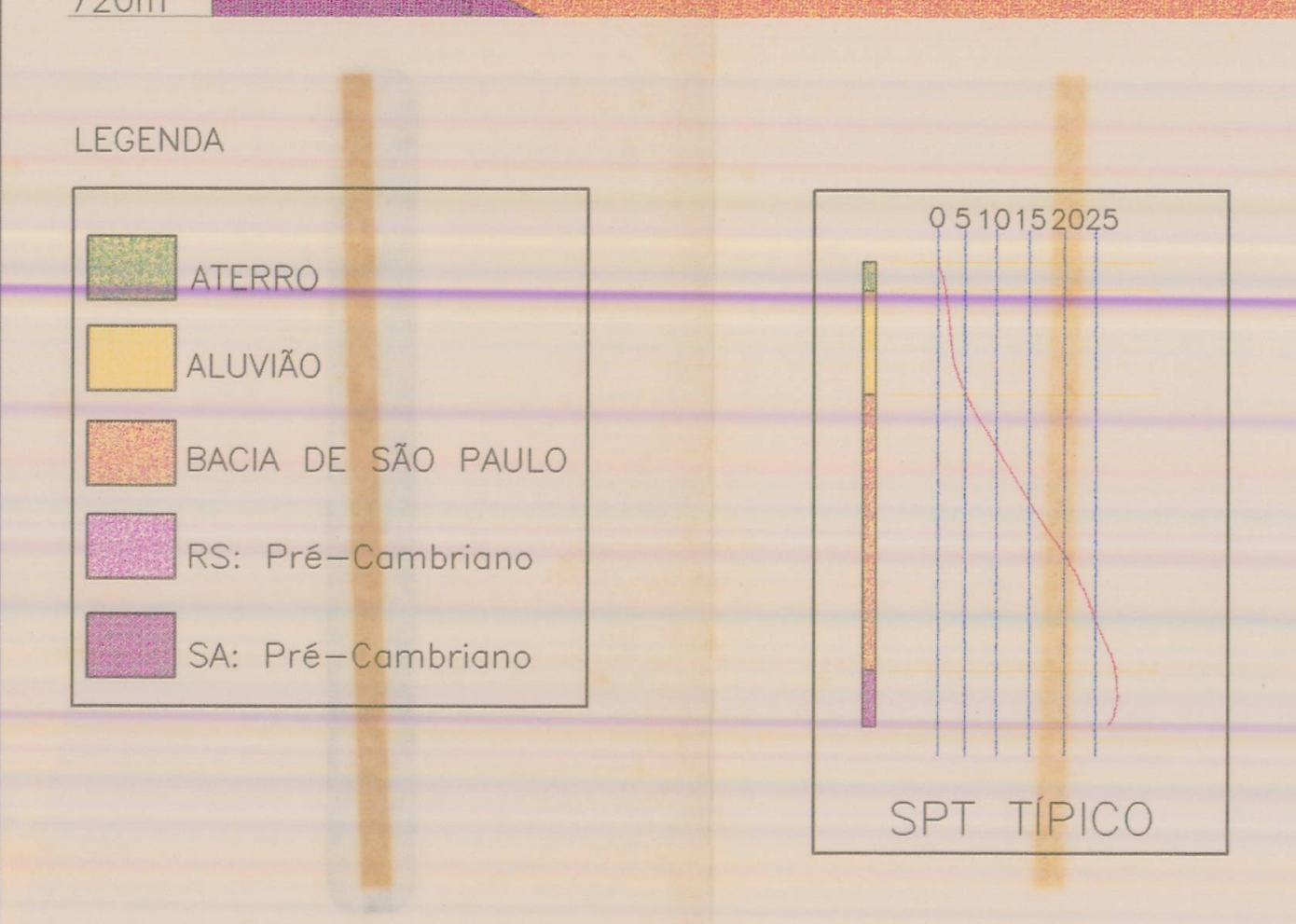

$0.100-\frac{300}{-600}-{ }^{1000 m}$ 


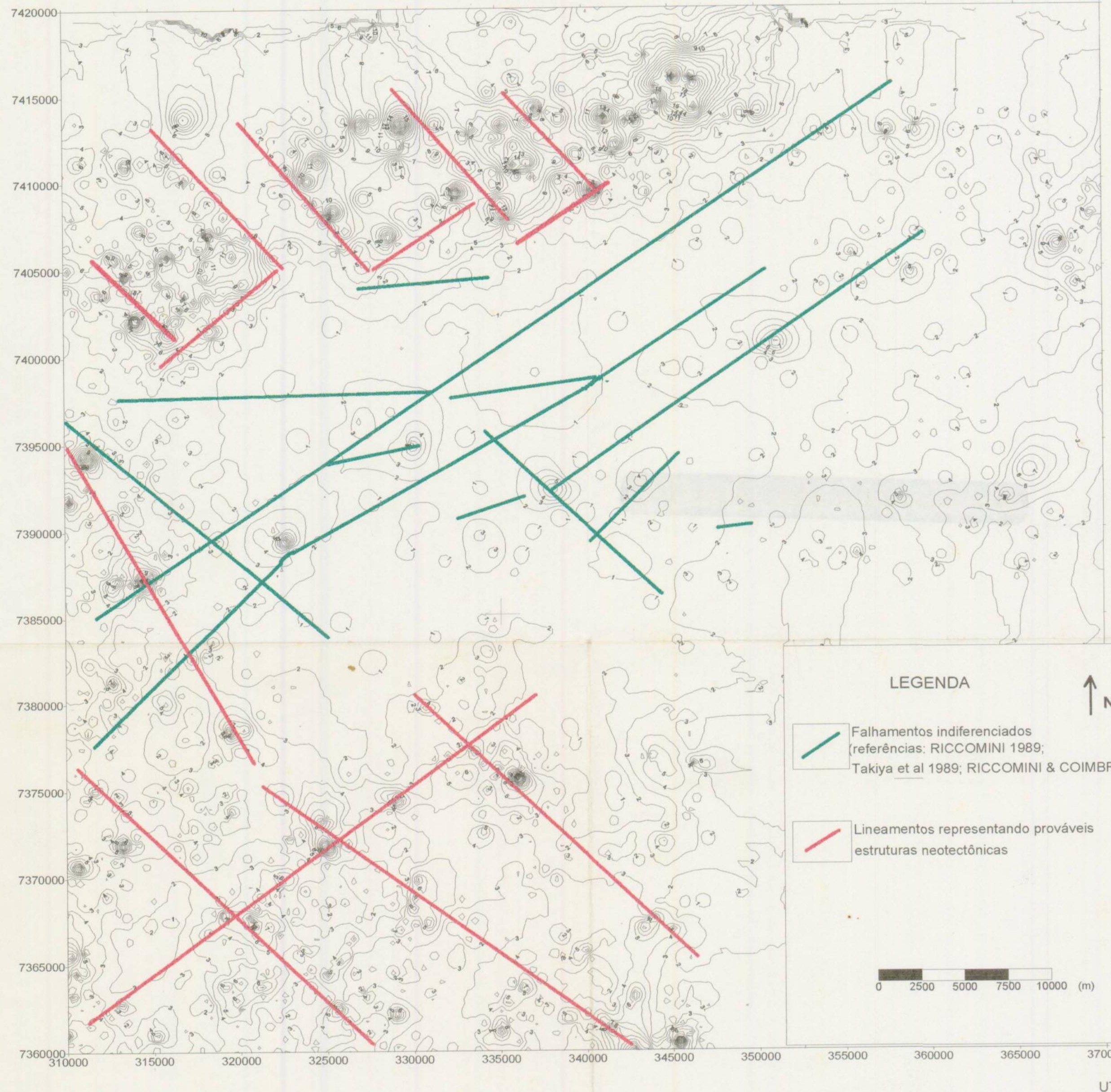

ANEXO C

Mapa de isovalores de gradientes hidráulicos e estruturas tectônicas Harmi Takiya - Tese doutoramento - 1996 